\title{
Persoonskenmerken en essentiele hypertensie
}

Citation for published version (APA):

Schreurs, P. J. G. (1987). Persoonskenmerken en essentiele hypertensie. [, Maastricht University]. Rijksuniversiteit Limburg. https://doi.org/10.26481/dis.19870702ps

Document status and date:

Published: 01/01/1987

DOI:

10.26481/dis.19870702ps

Document Version:

Publisher's PDF, also known as Version of record

\section{Please check the document version of this publication:}

- A submitted manuscript is the version of the article upon submission and before peer-review. There can be important differences between the submitted version and the official published version of record.

People interested in the research are advised to contact the author for the final version of the publication, or visit the DOI to the publisher's website.

- The final author version and the galley proof are versions of the publication after peer review.

- The final published version features the final layout of the paper including the volume, issue and page numbers.

Link to publication

\footnotetext{
General rights rights.

- You may freely distribute the URL identifying the publication in the public portal. please follow below link for the End User Agreement:

www.umlib.nl/taverne-license

Take down policy

If you believe that this document breaches copyright please contact us at:

repository@maastrichtuniversity.nl

providing details and we will investigate your claim.
}

Copyright and moral rights for the publications made accessible in the public portal are retained by the authors and/or other copyright owners and it is a condition of accessing publications that users recognise and abide by the legal requirements associated with these

- Users may download and print one copy of any publication from the public portal for the purpose of private study or research.

- You may not further distribute the material or use it for any profit-making activity or commercial gain

If the publication is distributed under the terms of Article $25 \mathrm{fa}$ of the Dutch Copyright Act, indicated by the "Taverne" license above, 
PERSOONSKENMERKEN EN ESSENTIËLE HYPERTENSIE 
Promotores: Prof. Dr. A.P.W.M. Appels Prof. Dr. J.A.M. Winnubst Prof. Dr. K.H. Rahn

Referenten: Prof. Dr. S.M.J.C. Maes Prof. Dr. M.M.W. Richartz

Het onderzoek beschreven in hoofdstuk 6 is uitgevoerd met steun wan het Praeventiefonds en de Researchpool-post van de Rijksuniversiteit Utrecht. 


\section{PERSOONSKENMERKEN EN ESSENTIËLE HYPERTENSIE}

\section{ACADEMISCH PROEFSCHRIFT}

ter verkrijging van de graad van doctor in de Geneeskunde aan de Rijksuniversiteit Limburg te Maastricht, op gezag van de Rector Magnificus, Prof. Dr. F.I.M. Bonke, volgens het besluit van het College van Dekanen, in het openbaar te verdedigen op donderdag 2 juli 1987 om 14.00 uur

door

PETRUS JOHANNA GUILLAUME SCHREURS

geboren te Venlo in 1946 
$\begin{array}{llll}4 & \vdots & \vdots & \vdots\end{array}$ 


\title{
INHOUDSOPGAVE
}

\author{
VOORWOORD \\ INLEIDING
}

\section{THEORETISCH GEDEELTE}

\section{HOOFDSTUK 1}

1. REGULATIE VAN DE BLOEDDRUK EN HYPERTENSIE 7

1.1 Functies van het bloed 7

1.2 Bloedcirculatie: hart en vaten 7

1.3 Arteriële bloeddruk 8

$1.4 \quad$ Regeling van de arteriële bloeddruk $\quad 8$

-1.4.1 Regeling van de hartprestatie 9

1.4.1.1 Neurale factoren $\quad 9$

$\begin{array}{ll}\text { 1.4.1.2 Humorale factoren } & 10\end{array}$

$\begin{array}{ll}\text { 1.4.2 Regeling van de perifere weerstand } & 10\end{array}$

$\begin{array}{lll}1.4 .2 .1 & \text { Neurale factoren } & 10\end{array}$

1.4.2.2 Humorale factoren 11

1.5 Het meten van de bloeddruk 12

1.6 Normale bloeddruk, lichte, belangrijke en ernstige bloeddrukverhoging 13

$\begin{array}{lll}1.7 & \text { Essentiële en secundaire hypertensie } & 15\end{array}$

$\begin{array}{lll}1.7 .1 & \text { Epidemiologie } & 16\end{array}$

$\begin{array}{lll}\text { 1.7.2 Hypertensie en consequenties voor de gezondheid } & 18\end{array}$

\section{HOOFDSTUK 2}

2. ESSENTIËLE HYPERTENSIE:

$\begin{array}{lll}2.1 & \text { Risicofactoren } & 21\end{array}$

2.1.1 Erfelijkheid : 21

2.1.2 Zout 22

2.1.3 Overgewicht 23

2.1.4 Alcohol 25

2.1.5 Stress 25

2.2 Sociale omgeving 28

2.3 Levensgebeurtenissen 31

$2.4 \quad$ Sociale steun 33

$\begin{array}{lll}2.5 & \text { Reactiviteit van de bloeddruk } & 35\end{array}$ 
2.6 Persoonlijkheidskenmerken, attitudes en gedragsstijlen 38

2.6.1 Onderdrukte agressie 38

2.6.2 Neuroticisme en angst $\quad 42$

2.6.3 Subassertiviteit 44

2.6.4 Beheersingsoriëntatie $\quad 45$

2.6.5 Type-A gedragspatroon $\quad 47$

2.6.6 Samenvatting 50

HOOFDSTUK 3

3 STRESS, COPING EN HYPERTENSIE

HOOFDSTUK 4

4 THEORETISCHE UITGANGSPUNTEN EN

VRAAGSTELLING VAN HET ONDERZOEK

\section{EMPIRISCH GEDEELTE}

\section{HOOFDSTUK 5}

5. PERSOONLIJKHEIDSKENMERKEN EN ESSENTIËLE HYPERTENSIE

Het BGD-onderzoek

5.1 Methode $\quad 65$

5.1.1 Hypothesen $\quad 65$

5.1.2 Beschrijving van de steekproef 66

5.1.3 Beschrijving van de psychologische meetinstrumenten 68

5.1.3.1 Vragenlijst Recent Meegemaakte Gebeurtenissen (VRMG, versie 1)

5.1.3.2 Taylor Manifest Anxiety Scale (TMAS, in verkorte versie van Bendig): het meten van angst

5.1.3.3 Eysenck Personality Inventory (EPI): het meten van extraversie en neuroticisme

5.1.3.4 Leidse Lijst Sociale Situaties (LLSS): het meten van sociale angst

5.1.3.5 Interne-externe Locus of Control, de Rotter I-E schaal (I-E): het meten van beheersingsoriëntatie

5.1.3.6 Jenkins Activity Survey (JAS): het meten van type-A gedragspatroon

5.1.3.7 Defense Mechanism Inventory (DMI): het meten van defensie-mechanismen

5.1.4 Intercorrelaties psychosociale variabelen 
5.1.5 Statistische procedures $\quad 80$

$\begin{array}{lll}5.2 & \text { Resultaten } & 81\end{array}$

5.2.1 Leeftijd en quetelet-index 81

5.2.2 Psychologische verschillen tussen subgroepen

5.2.3. Psychologische verschillen tussen hypertensieven en normotensieven $\quad 84$

$\begin{array}{lll}\text { 5.2.3.1 Levensgebeurtenissen } & 84\end{array}$

5.2.3.2 Persoonlijkheidskenmerken $\quad 86$

- angst 86

- neuroticisme $\quad 86$

- extraversie $\quad 86$

- assertiviteit : 87

$\begin{array}{ll}\text { - beheersingsorientatie } & 87\end{array}$

- type-A gedragspatroon $\quad 88$

- defensie-mechanismen $\quad \ldots 8$

$\begin{array}{lll}\text { 5.2.4 Subgroepen van hypertensieven } & 89\end{array}$

HOOFDSTUK 6

6. PSYCHOSOCIALE FACTOREN EN

ESSENTIËLE HYPERTENSIE

Op het spoor van coping: het NS-onderzoek

$\begin{array}{lll}6.1 & \text { Methode } & 95\end{array}$

6.1.1 Hypothesen 96

$\begin{array}{lll}6.1 .2 & \text { Bloeddrukmeting } & 97\end{array}$

$\begin{array}{lll}\text { 6.1.3 Beschrijving van de steekproef } & 97\end{array}$

6.1.4 Criteria voor 'hypertensief' en 'normotensief' 98

6.1.5 Psychosociale variabelen: beschrijving van de

6.1.5.1 - Levensomstandigheden (LOM) 101

6.1.5.2 - Vragenlijst Recent Meegemaakt Gebeurtenissen (VRMG) 102

6.1.5.3 - Zelf Beoordelings Vragenlijst (ZBV): het meten van angst 104

6.1.5.4 - Schaal voor Interpersoonlijk Gedrag (SIG): het meten van assertiviteit

6.1.5.5 - Interne-externe 'locus of control" (IE): beheersingsoriëntatie

6.1.5.6 - Jenkins Activity Survey (JAS): het meten van het type-A

- gedragspatroon

6.1.5.7 - Zelf Analyse vragenlijst (ZAV): het meten van : $\quad 105$

6.1.5.8 - Utrechtse Coping Lijst (UCL): het meten van coping 106 
6.1.5.9 Defensie Mechanismen Lijst (DMI): het meten van defensiemechanismen

6.1.6.1 Relatie leeftijd en psychosociale variabelen 112

6.1.6.2 Intercorrelaties psychologische variabelen $\quad 113$

$\begin{array}{ll}\text { 6.1.6.3 Second order factoranalyse } & 116\end{array}$

$\begin{array}{ll}\text { 6.1.7 Dataverwerking en statistische procedures } & 117\end{array}$

6.2 Resultaten

6.2.1 Verschillen tussen hypertensieven en normotensieven - leeftijd, quetelet-index, cholesterol, sociale klasse

6.2.2 Invloed van medicijngebruik, diagnose en duur van de hypertensie

6.2.3 Sociale omstandigheden en verschillen tussen hypertensieven en normotensieven

- sociale steun en partnerrelatie $\quad 122$

- werkbelasting 123

- financiële problemen $\quad 123$

- jeugdervaring 123

- problemen met kinderen 123

6.2.4 Psychologische verschillen tussen hypertensieven en normotensieven

$\begin{array}{lll}6.2 .5 & \text { Subtypen van hypertensieven } & 126\end{array}$

6.2.6 Interacties tussen sociale factoren en persoonlijkheidskenmerken

\section{HOOFDSTUK 7}

7 NABESCHOUWING 137

$\begin{array}{lll}7.1 & \text { Indelingscriteria voor hypertensie en normotensie } & 137\end{array}$

$\begin{array}{lll}7.2 & 138\end{array}$

$\begin{array}{lll}7.3 & \text { Impact diagnose en de duur van de hypertensie } & 138\end{array}$

$\begin{array}{lll}7.4 & \text { Sociale omstandigheden } & 139\end{array}$

$\begin{array}{ll}7.5 & \text { Psychologische kenmerken } \\ 7.50\end{array}$

$\begin{array}{ll}7.5 .1 & \text { Angst en neuroticisme } \\ 7.5 .2 & 140\end{array}$

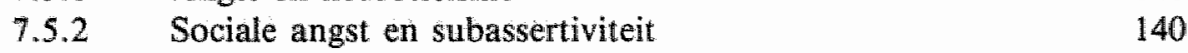

$\begin{array}{lll}7.5 .3 & \text { Beheersingsoriëntatie : } 141\end{array}$

$\begin{array}{lll}7.5 .4 & \text { Type-A gedragspatroon } & 142\end{array}$

$\begin{array}{lll}7.5 .5 & \text { Boosheidsdispositie } & 142\end{array}$

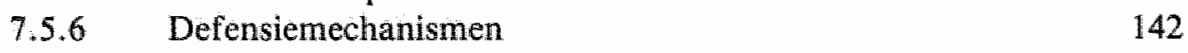

$\begin{array}{lll}7.5 .7 & \text { Copinggedrag } & 143\end{array}$

$\begin{array}{lll}7.6 & \text { Subtypen van hypertensieven } & 143\end{array}$

$\begin{array}{lll}7.7 & \text { Wijziging van het onderzoeksparadigma } & 145\end{array}$ 
LITERATUURLIJST

BIJLAGEN

- Bijlage A Vragenlijst levensomstandigheden (LOM)

- Bijlage B Vragenlijst Recent Meegemaakte Gebeurtenissen (VRMG) 169

- Bijlage C Tabel indices van gebeurtenissen

- Bijlage D Vragenlijst Omgaan met Problemen en Gebeurtenissen De Utrechtse Copinglijst (UCL)

- Bijlage E Vragenlijst Defensie Mechanismen (DMI) 


\section{VOORWOORD}

Het boek dat voor u ligt kent een lange geschiedenis. Reeds 10 jaar geleden werd ik geboeid door het onderwerp essentiele hypertensie: een verhoogde bloeddruk waarvan tot nog toe geen duidelijk aanwijsbare organische oorzaak kon worden aangetoond. In het kader van een post van de researchpool van de Rijksuniversiteit Utrecht onderzocht ik de therapeutische toepassingsmogelijkheden van biofeedback-procedures van essentiele hypertensie'. Zowel biofeedback als hypertensie waren nieuwe gebieden binnen de sociale wetenschappen. Snel werd duidelijk dat de standaard meetmethode (Riva Rocci) om de bloeddruk te meten weinig geschikt is voor biofeedback doeleinden en dat naar andere mogelijkheden gekeken moest worden om de bloeddruk gedurende langere tijd te meten. Het pionierswerk heb ik destijds verricht met Maarten van de Loo, Henk Vroom en Jaap Woestenburg met wie ik heb gewerkt aan het meten van de voortplantingssnelheid van de drukgolf, via de Doppler-methode, als indicatie voor de bloeddruk. Het is echter niet het onderwerp van de dissertatie geworden. De basis hierwoor werd gelegd door therapeutische ervaringen met biofeedback-procedures, zoals spierspannings-feedback en met relaxatietrainingen. Het vermoeden werd sterker dat een blijvende bloeddrukverlaging bij hypertensieven pas gerealiseerd kon worden, indien biofeedback geintegreerd zou worden in een ruimer therapeutisch kader. Hiertoe was het noodzakelijk om meer inzicht te hebben in de rol van psychosociale factoren bij hypertensie. Kennis van specifieke persoonskenmerken van hypertensieven zou een gerichtere therapie-indicatie kunnen opleveren. In de literatuur heerste de opvatting dat mensen met verhoogde bloeddruk hun agressieve gevoelens onderdrukten en veelal subassertief en angstig waren. De onderzoeksresultaten waren echter niet overtuigend en soms was er sprake van strijdige opvattingen.

Door medewerking van Dr. A. Prins kregen we een kans om enkele psychologische vragenlijsten voor te leggen aan respondenten van een bevolkings-onderzoek ter opsporing van verhoogde bloeddruk in Krimpen aan de IJssel. Mede dankzij zijn steun en die van de medewerkers van het gezondheidscentrum konden Guido Godaert, Maarten van Son en ik aan grote groepen mensen, mét en zonder een te hoge bloeddruk, een aantal vragenlijsten voorleggen. Geen van de gemeten kenmerken bleek te discrimineren tussen hypertensieven en normotensieven.

We zochten vervolgens naar een mogelijkheid in contact te komen met een groot aantal personen van wie de bloeddruk nauwkeurig kon worden gemeten en bij wie we gelijktijdig een groot aantal psychologische vragenlijsten konden voorleggen. Bij de voorbereidingen werd $\mathbf{i k}$ geholpen door de studenten Kees 
van Kuilenburg, Ria Zuidema, Wim de Boer en Gerard Karelse. Gerard was het die intensief contacten aanging met de BGD. Door de medewerking van de zeer geinteresseerde Dr. J. Lagerweij kreeg ik praktisch alle onderzoeksmogelijkheden bij de Bedrijfs Geneeskundige Dienst Utrecht: Dank ben ik ook verschuldigd aan Dr. $K$. Oei die mij de laatste maar noodzakelijke gegevens heeft verstrekt.

Bijzonder erkentelijk ben ik de heren A. Banning, J. Bosman en J. Burger die het mogelijk hebben gemaakt om aan te sluiten bij het periodiek geneeskundig onderzoek van de Nederlandse Spoorwegen. Zonder de accuratesse en inspanning van de medewekers die deze keuringen verrichtten, was dit onderzoek onmogelijk geweest. Zeer bijzonder wil ik danken Henk Fengler die mij altijd ter wille is geweest en ervoor gezorgd heeft dat de afspraken die ik destijds met Frits Bosch had gemaakt, konden worden nagekomen.

Participatie aan de werkgroep 'psychosociale determinanten van het hartinfaret', deed mij besluiten de initiatiefnemer van deze groep Prof. Dr. A. Appels te vragen als promotor op te treden. Mede door diens kritische wijze waarop alle hoofdstukken werden begeleid, kan ik het eindproduct het daglicht laten zien. Ad, je stimuleerde mij ook de cursus epidemiologie van Miettinen Ph.D. van de Harvard University te volgen en mee te werken aan een tweetal WHO-bijeenkomsten. Dank voor al je inspanning.

Mijn promotor Prof. Dr. J.A.M. Winnubst dank ik niet alleen voor zijn inhoudelijke begeleiding maar ook voor zijn morele steun die hij me gaf tijdens momenten die je zo snel mogelijk vergeten wilt. De social support valt niet ver van de boom.

Prof. Dr. K.H. Rahn ben ik erkentelijk voor zijn deskundige begeleiding van de medische aspecten van het onderzoek.

Tevens wil ik graag de beide referenten Prof. Dr. M. Richartz en Prof. Dr. S. Maes bedanken voor hun bereidheid het manuscript inhoudelijk te beoordelen en van commentaar te voorzien.

Het schrijven van dit voorwoord gebeurt op een moment kort voor het inleveren van het manuscript bij de drukker. Maarten van Son en Kees van Kuilenburg en Mieke Reezigt-Aafjes wil ik nog zeer bedanken voor het nauwkeurig doornemen van de tekst. Zij hebben mij er op gewezen dat het Venlose taalgebruik helaas nog steeds geen $\mathrm{ABN}$ mag worden genoemd.

Het is overigens geen onprettige zaak om terug te blikken in de tijd en te constateren hoeveel mensen mij geholpen hebben bij de werkzaamheden voor deze dissertatie. Alle collega's, studenten en anderen wil ik hiervoor danken maar in het bijzonder gaan mijn gedachten uit naar Gerard van de Willige. Zijn nauwgezetheid, zijn soepelheid, diplomatie en zijn specifieke deskundigheden waren voor mij onontbeerlijk. We hadden elkaar zoveel te vertellen dat we niet genoeg hadden aan de gebruikelijke diensttijden van 
ambtenaren zodat we onze gesprekken op vrijdagavond moesten voortzetten bij 'Arie op de brug' en soms bij Van Wegen. Hierbij werden we 'geholpen' door Leo 'Schiesser' en Jan Kruitwagen. Na het vertrek van Gerard van de Willige naar Groningen hebben achtereenvolgens Jaap Verhage, Bert Tellegen, Jos Brosschot, Martin Euser, Mieke Spronk en vooral Ernest de Vroome mij tot grote tevredenheid geholpen in de jungle van de statistische procedures.

Mijn activiteiten achter de tekstverwerker zijn mijn buurtgenoten en vrienden niet ontgaan. Onbegrip en waardering heb ik van hen mogen ontvangen. Ik kan hen verzekeren dat spoedig de contacten worden geintensiveerd, of men wil of niet.

Het werk heeft de laatste jaren zowel mijn vrije tijd als die van mijn gezin. opgeëist. Mijn vrouw Annemie dank ik voor al haar typewerkzaamheden in de beginfase en voor de energie die ze telkens heeft kunnen opbrengen om mijn geweeklaag aan te horen. Mijn beide zonen Onno en Mark misten mij wel eens, gezien de vaak pijnlijke opmerkingen of ik nu weér met een nieuw boek bezig was en hoeveel laatste pagina's een boek eigenlijk wel heeft.

Dankbaar ben ik ook de beide televisiestations die het voor elkaar hebben gekregen om de laatste jaren een oninteressant programma te bieden zodat ik niets heb hoeven te missen.

Tenslotte wil ik danken Mevr. E.J.M. Ströbl-Swane voor de toestemming de tekeningen van haar man Stephan Ströbl te mogen publiceren. Deze tekeningen zijn destijds tot stand gekomen in nauw overleg met Prof. Jhr. Dr. D.J. van Lennep, de oprichter van de vakgroep klinische psychologie (voorheen het ICIP) van de Rijksuniversiteit Utrecht, dezelfde vakgroep die mij mede de gelegenheid heeft gegeven dit onderzoek uit te voeren. 


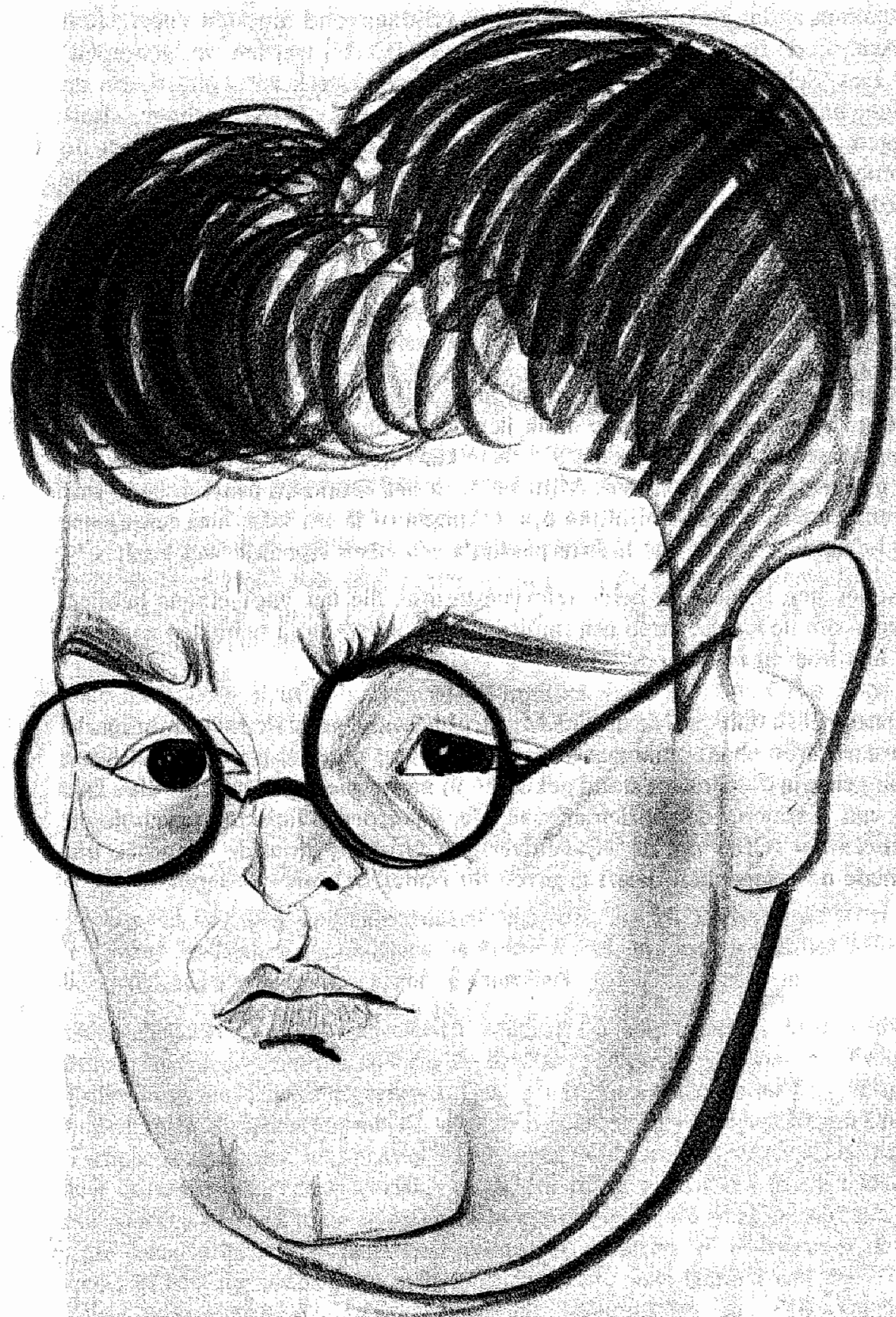

$t_{m, \alpha} A$ ma

, 0 


\section{INLEIDING}

De betekenis van persoonlijkheidskenmerken voor de etiologie van essentiële hypertensie is reeds vele decennia een onderwerp van discussie. Door psychodynamisch georienteerde onderzoekers werd gesteld dat verdrongen emotionele conflicten aan de basis kunnen liggen van essentiële hypertensie (Ayman, 1933, Binger e.a. 1945).

Alexander (1939) stelt op grond van een psychoanalytische studie van een 47 jarige hypertensiepatiënt het volgende vast: 'er zijn diep verdrongen, agressieve impulsen, deels naar binnen gericht tegen de eigen persoon in de vorm van depressies, deels naar buiten gekeerd in de vorm van hostiele gevoelens'.

Saul (1939) heeft Alexanders leer van het specifieke emotionele conflict verder uitgewerkt. Op zichzelf beschouwd, zo betoogt hij, betekent een conflict tussen afhankelijkheidswensen en agressiviteit niets bijzonders. Van beslissende invloed voor het ontstaan van hypertensie is de wijze waarop met het conflict wordt omgegaan.

In ons land komen in diezelfde tijd Groen e.a. (1948) en Van de Loo (1952) tot overeenkomstige bevindingen. Volgens Van de Loo kon uit de Rorschachtests van personen met hypertensie worden afgeleid dat ze een typische levenswijze hadden ontwikkeld die hij omschreef als 'protestvolle onderdrukking. Er was sprake van een vroegtijdig ontstaan conflict tussen agressieve gevoelens vanwege onthouding van liefde en respect en een tegelijkertijd aanwezige autoriteits- en ongeborgenheidsvrees" (Van de Loo, 1952).

Groen beperkte zich in zijn onderzoek niet tot het opsporen en beschrijven van speeifieke, emotionele conflicten bij mensen met hypertensie. Naast aandacht voor het 'predisponerende karakter der patienten', achite hij ook andere factoren van belang zoals de aard van de 'stress'-situatie en de bijzondere wijze waarop het psychotrauma werd verwerkt. In de visie van Groen dient men de mens te zien als een 'sociopsychosomatische eenheid'. Daarmee werd definitief gebroken met het zogenaamde 'sole-cause attitude of mind', hetgeen wil zeggen dat meer dan een oorzaak verantwoordelijk is voor het ontstaan van ziekten. Er is namelijk sprake van multicausaliteit waarbij een constellatie van psychologische, somatische, hereditaire en situatieve factoren bij het ontstaan van ziekten meespeelt. Ondanks deze denkbeelden rondom de etiologie van psychosomatische klachten en van essentiele hypertensie in het bijzonder, bleef het onderzoek in die tijd voornamelijk beperkt tot het opsporen van de 'hypertensie-persoonlijkheid".

Naast onderzoek naar de 'onderdrukte-agressie-theorie' van Alexander 
$(1939,1950)$ is het verband nagegaan van diverse psychologische kenmerken en condities als angst, gejaagdheid, rusteloosheid, obsessief en compulsief gedrag (zie Harrel, 1980). Omtrent de rol van persoonlijkheidskenmerken bij het ontstaan en beloop van essentiële hypertensie is de laatste 50 jaar intensief onderzoek verricht. Duidelijk is geworden dat het onderzoek naar specifieke gedragskenmerken yan mensen met essentiele hypertensie zich niet mag beperken tot het klassiek zoeken naar univariate verbanden met persoonlijkheidskenmerken.

Weiner(1979) ziet de etiologie van essentiële hypertensie als een ingewikkeld samenspel van verschillende factoren op zowel sociaal, psychologisch, cultureel als fysiologisch niveau. Hij trekt de vergelijking met een mozaïek dat als een puzzel in elkaar moet worden gelegd.

Door Kaplan (1978) en Gientry e.a. (1982) wordt eveneens gewezen op de heterogeniteit van hypertensie en de multifactoriële aspecten die bij de etiologie een rol spelen.

De heterogeniteit komt tot uiting doordat verschillende pathogenetische mechanismen kunnen leiden tot hypertensie (Kaplan, 1978). Aan dit proces kunnen verschillende psychosociale factoren ten grondslag liggen.

Deze dissertatie is als volgt opgebouwd: allereerst worden de fysiologische aspecten yan het bloeddrukregelmechanisme besproken. Vervolgens wordt nader ingegaan op enkele aspecten van assessment en het onderscheid tussen essentiële en secundaire hypertensie. Daarnaast komen er epidemiologische gegevens aan de orde met betrekking tot het vóórkomen van hypertensie in Nederland waardoor de geweldige omvang van het probleem voor de volksgezondheid wordt aangetoond.

In hoofdstuk 2 komen de mogelijke oorzaken van essentiële hypertensie aan de orde. Achtereenvolgens wordt kort de betekenis toegelicht van erfelijkheid, zoutgebruik en lichaamsgewicht. Uitvoeriger wordt de rol van 'stress' aan de orde gesteld: de gedachte dat een langdurige aanpassing aan psychosociale situaties kan leiden tot functiestoornissen en somatische klachten, wordt ook gesteund met betrekking tot essentiële hypertensie (Weiner, 1979). De onderzochte situaties en omstandigheden variëerden van langdurige blootstelling aan lawaai (Talbott e.a. 1985) tot complexe sociale situaties als werkloosheid c.q. dreiging daarvan (Kasl en Cobb,1980) en de arbeidsomstandigheden van verkeersleiders op Amerikaanse vliegvelden (Cobb e.a.1973; Jenkins e.a. 1984). Uit deze studies wordt duidelijk dat de manier van omgaan met ingrijpende gebeurtenissen en langdurig belastende situaties van grote invloed kan zijn op het ontstaan en handhaven van essentiële hypertensie. Deze wijze van orngaan met problemen wordt voor een groot gedeelte bepaald door leerervaringen, sociale omstandigheden en persoonlijkheidskenmerken.

Hoofdstuk 3 vermeldt enkele theoretische uitgangspunten met betrekking tot 
het concept 'coping': de manier waarop lemand zowel gedragsmatig, cognitief als emotioneel op aanpassing vereisende omstandigheden reageert. In dit proces spelen situationele en persoonlijkheidsvariabelen een grote rol. Als ordeningsprincipe voor het onderzoek naar de relatie tussen psychosociale factoren en essentiële hypertensie wordt een onderzoeksmodel gehanteerd dat is opgesteld in samenwerking met Van de Willige (1983). Dit model bevat elementen van diverse andere stressmodellen zoals die van Lazarus (1966) en Kagan en Levi (1974). Dit multiconditionele model beschrijft het proces dat aanvangt met een aanpassing vereisende gebeurtenis of een problematische levensomstandigheid, hetgeen kan leiden tot essentiële hypertensie. De tussenliggende factoren hebben betrekking op eigenschappen van de sociale omgeving en op het individu, dat toegerust met bepaalde persoonlijkheids- en gedragskenmerken, de belastende situaties percipiëert en ermee omgaat. We spreken van 'stress' wanneer de waargenomen eisen vanuit de omgeving de waargenomen eigen competentie om ermee om te gaan overschrijden. Dit gaat gepaard met een verhoogde fysiologische activiteit. Deze verhoogde activiteit van het centralle zenuwstelsel kan direct leiden tot merkbare lichamelijke klachten. Ook is het mogelijk dat bij voortduring van deze verhoogde activiteit er bepaalde veranderingen in de functie en structuur van orgaansystemen kunnen optreden, die zorgen voor een permanent verhoogde bloeddruk.

De vraagstelling van de te beschrijven onderzoeken wordt besproken in hoofdstuk 4 aan de hand van het bovengenoemde onderzoeksmodel.

Er worden vervolgens twee onderzoeken beschreven waarin de relatie wordt nagegaan tussen psychosociale factoren en essentiële hypertensie. In het eerste onderzoek, dat is uitgevoerd bij de Bedrijfsgeneeskundige Dienst 'Utrecht' (BGD) beperken we ons in eerste instantie tot de relatie tussen persoonlijkheidskenmerken en hypertensie. Op een aantal relevante persoonlijkheidskenmerken worden hypertensieven vergeleken met normotensieven. In het tweede onderzoek, dat is uitgevoerd bij de Nederlandse Spoorwegen is deze vraagstelling wederom opgenomen. Behalve persoonlijkheidskenmerken worden ook sociale factoren in het onderzoek betrokken. Zo worden de woon-, werk- en leefomstandigheden van de respondenten geïnventariseerd.

De onderzoekspopulatie is in vergelijking met het eerste onderzoek aanzienlijk groter. Dit biedt de mogelijkheid om binnen de groep hypertensieven een onderscheid te maken met betrekking tot een aantal variabelen, namelijk de tijd dat de bloeddruk verhoogd is, het al dan niet gebruiken van medicijnen en het bekend zijn met de diagnose hypertensie.

Verder is onderzocht of er binnen de groep hypertensieven sprake is van subgroepen die zich met betrekking tot psychosociale factoren onderscheiden van normotensieven. De veronderstelling is dat er twee subgroepen hypertensieven zijn die zich onderscheiden in de wijze waarop zij met 
gebeurtenissen en problemen omgaan ('coping-gedrag'). De ene groep kenmerkt zich door een actief en gehaast gedrag, dat voortvloeit uit angst voor met name een verlies van controle op de omgeving. Bij de andere groep valt op dat zij erg defensief is ingesteld en gebruik maakt van passieve copingstrategieen: veelal wordt het bestaan van moeilijke omstandigheden en problemen ontkend dan wel gebagatelliseerd.

De conclusies die we kunnen trekken uit beide onderzoeken staan vermeld in hoofdstuk 7 . 








\section{THEORETISCH GEDEELTE}

\section{HOOFDSTUK 1}

\section{REGULATIE VAN DE BLOEDDRUK EN HYPERTENSIE}

\subsection{FUNCTIES VAN HET BLOED}

Een ongestoorde circulatie van het bloed is van vitaal belang voor het organisme. Het verzorgt de aanvoer van voedingsstoffen en zuurstof die het weefsel nodig heeft en voert alle overtollige stoffen en verbrandingsprodukten zoals koolzuur en water af. Verder heeft het bloed ook een belangrijke afweerfunctie tegen schadelijke invloeden uit de buitenwereld zoals bij verwondingen. Het geheel van de stofwisseling wordt voor een belangrijk deel geregeld door het autonome zenuwstelsel en gedeeltelijk door het hormonale stelsel. Hoezeer de bloedvoorziening hierbij betrokken is wordt bijzonder duidelijk wanneer bijvoorbeeld lichamelijke inspanning geleverd moet worden: voor de omzetting van stoffen in energie (katabolisme) is een vergrote toevoer van zuurstof nodig. Deze zuurstoftoevoer kan alleen plaatsvinden als er voldoende bloed langs de longen en naar de spieren gevoerd wordt. Bovendien is voor het leveren van inspanning een vergroot transport van enegieleverende stoffen en van water en zouten vereist. Dit transport is volledig afhankelijk van een adequate bloedcirculatie en bloeddruk. Vaatverwijding kan in de metabole behoeften bij spierarbeid voorzien (Coleman, 1979).

In rust zijn voornamelijk anabole processen actief en worden nieuw weefsel en afweerstoffen gevormd. Tijdens dit proces overheerst de parasympatische invloed van het centrale zenuwstelsel en is de sympatische minimaal (Sheperd, 1981; Manning, 1985).

\subsection{BLOEDCIRCULATIE: HART EN VATEN}

De bloedstroom komt tot stand door drukverschillen veroorzaakt door de pompwerking van het hart. De aanvoer van het bloed van het hart naar de weefsels vindt plaats via de slagaderlijke (arteriële) bloedvaten. In dit gedeelte van de circulatie werkt het hart als perspomp: bij iedere hartslag wordt een bepaald volume bloed het leidingenstelsel ingepompt. Hier heerst dan ook een vrij hoge druk, de zogenaamde arteriële bloeddruk.

De wanden van de arteriën zijn elastisch zodat ze kunnen uitrekken bij een bloeduitstoot door het hart. Hierdoor wordt aan het eind van het arteriële systeem een gelijkmatige bloedstroom bereikt.

De slagaderen vertakken zich bij de organen in uitwaaierende netwerken van 
zeer kleine bloedvaten (arteriolen), die vervolgens weer overgaan in netwerken van haarvaten (capillairen). Deze verenigen zich tot aderen, die in de richting van het hart in grootte toenemen. De doorlaatcapaciteit is variabel; wanneer een bepaald orgaan veel bloed nodig heeft wordt deze doorlaatcapaciteit vergroot door middel van vaatverwijding (vasodilatatie), en wanneer weinig bloed nodig is, dan wordt zij verkleind door middel van vaatvernauwing (vasoconstrictie). Er stroomt zo minder bloed uit het arterieel in het capillair deel van het vaatstelsel. Vanuit de weefsels stroomt het bloed weer terug naar het hart. Dit gebeurt via het aderlijke (veneuze) deel van de circulatie. De veneuze bloeddruk is lager dan de arteriële bloeddruk.

\subsection{ARTERIËLE BLOEDDRUK}

Om het bloed effectief in alle weefsels en organen te laten doordringen is een bepaalde druk nodig. De bloeddruk is de kracht die het bloed uitoefent op de wand van de bloedvaten. De bloeddruk wordt uitgedrukt in millimeters kwik. Doordat het hart op een ritmische wijze contraheert zien we aan het begin van het arterieel stelsel een stootsgewijs drukverloop. Voor een gelijkmatige bloedyoorziening van het capillaire stelsel is echter een gelijkmatig drukverloop vereist. Dit wordt tot stand gebracht door de elasticiteit van de arteriële vaatwanden. De stroomsnelheid van het bloed en ook de hoogte van de bloeddruk veranderen steeds met het hartritme. $\mathrm{Zij}$ zijn het grootst tijdens de samentrekking van het hart en het laagst tijdens de verslapping van het hart tussen twee samentrekkingen in. Het samentrekken van het hart noemt men systole en het verslappen de diastole van het hart.

Vlak na de contractie van het linkerventrikel - de ventrikelsystole - is de druk in het arteriële stelsel het hoogst: de systolische druk.

Tijdens de ontspanning van het linkerventrikel - de ventrikeldiastole stroomt bloed af door de perifere vaten. Het bloedvolume in het arteriële stelsel wordt kleiner, waardoor de rekking van de vaatwanden afneemt. Op het laagste punt van deze ontspanning wordt de diastolische druk bereikt.

\subsection{REGELING VAN DE ARTERIËLE BLOEDDRUK}

De behoefte aan bloed van organen en spieren kan zeer sterk wisselen, afhankelijk van de eigen behoeften van het organisme of van omgevingsinvloeden. Aangezien de bloeddruk dan mee moet kunnen variëren is een uitgebreid aanpassings- en regelmechanisme aanwezig.

De arterièle bloeddruk wordt door twee factoren bepaald: het hartminuutvolume en de totale perifere weerstand die onder andere door de gezamenlijke arteriolae wordt opgebouwd. Zowel hartminuutvolume als de perifere weerstand worden beïnloed door het centrale zenuwstelsel. Naast dit direkt reagerende neurogene regelmechanisme beschikt ons lichaam ook nog 
over een wat langzamer reagerend systeem, waarbij verschillende hormonen een rol spelen, onder andere het renine-angiotensine systeem, terwijl ook de nier nog via zijn invloed op de zout-en waterhuishouding een belangrijk effect op de handhaving van de bloeddruk heeft. Dit mechanisme maakt het mogelijk dat het lichaam zich aanpast aan de omstandigheden waarin het verkeert: inspannende lichamelijke activiteiten vereisen bijvoorbeeld een ruimere bloedtoevoer naar de spieren. Koude, pijn, plotselinge geluiden, het roken van een sigaret, angst en andere emoties doen de bloeddruk tijdelijk stijgen. Ontspanning en slaap verlagen de bloeddruk. De variatie in bloeddruk kan voor een belangrijk deel toegeschreven worden aan de fysische en/of mentale activiteit. Gedurende een etmaal schommelt de bloeddruk met zo'n 40 tot $60 \mathrm{~mm} \mathrm{Hg}$ voor de systolische en met 15 tot $20 \mathrm{~mm} \mathrm{Hg}$ voor de diastolische druk.

\subsubsection{REGELING VAN DE HARTPRESTATIE}

\subsubsection{NEURALE FACTOREN}

Het hart wordt geinnerveerd door zenuwen, die deel uitmaken van het autonome zenuwstelsel. Hiervan werkt het sympatische deel door middel van de $\mathrm{Nn}$. accelerantes, waardoor het hart gestimuleerd wordt: vergroting van frequentie en contractiekracht, dus vergroting van het hartminuutvolume.

Deze zenuwen werken voornamelijk bij inspanning wanneer extra hoge eisen worden gesteld aan de bloedvoorziening. Het parasympatische deel werkt door middel van de $\mathrm{Nn}$ vagi. Deze hebben een frequentieverlagende invloed.

De Nn. vagi worden tijdens rust duidelijk beinvloed door de ademhaling:

- bij inademing daalt de vagustonus en stijgt dientengevolge de hartfrequentie,

- bij uitademing stijgt de vagustonus weer en daalt de hartslag.

Het hartregulatiecentrum bevindt zich in de hersenstam, het verlengde van het ruggemerg binnen de schedel (medulla oblongata) en met name in de daar gesitueerde reticulaire formatie. Het hartregulatiecentrum ontvangt zowel neurale als humorale impulsen uit de periferie.

De belangrijkste neurale invloeden komen uit:

- De drukgevoelige sensoren, ook wel baroreceptoren genoemd, Voor de hartegulatie liggen de belangrijkste in de aortaboog en de sinus caroticus. $\mathrm{Zij}$ zijn bijzonder effectief om bloeddrukveranderingen op korte termijn te corrigeren. Bij stijging van de arteriële bloeddruk beginnen deze sensoren te vuren waardoor via het hartregulatiecentrum de invloed van de vagus op het hart toeneemt en de hartfrequentie dus daalt.

- De chemosensoren: deze bevinden zich in de buurt van de baroreceptoren. $\mathrm{Zij}$ worden geprikkeld door daling van het zuurstofgehalte en de zuurgraad 
van het bloed en stijging van het kooldioxidegehalte. Hun invloed op het hartregulatiecentrum is echter minder groot. Veel sterker werken zij in op de ademhalingscentra, die immers direct de zuurstof- en koolstofuitwisseling tussen longen en bloed controleren.

- Impulsen uit de ademhalingscentra (AHC). Zoals opgemerkt is er in rust een duidelijk verband tussen ademritme en hartfrequentie: respiratoire arithmie. Er bestaan directe neurale verbindingen tussen het ademhalingscentrum en het hartregulatiecentrum, zodat wanneer het ademhalingscentrum geprikkeld wordt, ook meteen het hartregulatiecentrum gestimuleerd wordt, hetgeen vergrote hartactie tot gevolg heeft (Grossman, 1983).

Naarmate - om welke reden dan ook - de vagustonus vermindert, dus de hartfrequentie stijgt, neemt het verschijnsel van de respiratoire arithmie in betekenis af.

\subsubsection{HUMORALE FACTOREN}

Hoewel over de invloed van humorale factoren op de werking van het hart weinig bekend is, kan men aannemen dat een stijging van het $\mathrm{CO}_{2}$ gehalte en een daling van het $\mathrm{O}_{2}$ gehalte van het arteriele bloed rechtstreeks op het hartregulatiecentrum inwerken en een verhoogde sympatische invloed op het hart veroorzaken via de $\mathrm{Nn}$. accelerantes.

Een verlaagde $\mathrm{CO}_{2}$ spiegel zal daarentegen via een verhoogde vaguswerking een frequentiedaling veroorzaken. Via de bloedbaan wordt het hart ook hormonaal gestimuleerd, en wel door het hormoon adrenaline dat door het bijniermerg aan het bloed wordt afgegeven. Vooral tijdens lichamelijke en geestelijke inspanning wordt veel adrenaline geproduceerd.

\subsubsection{REGELING VAN DE PERIFERE WEERSTAND}

Evenals bij het hartregulatie mechanisme kan hier het onderscheid tussen intrinsieke en extrinsieke beïnvloeding worden gemaakt. Anders dan bij de hartregulatie zijn hier echter de intrinsieke factoren van grotere betekenis: door hun werking 'ter plaatse' wordt voor een deel voldaan aan de bloedbehoefte van weefsels en organen. De daarvoor nodige vaatverwijding of -vernauwing werkt gedeeltelijk autonoom, zonder invloeden van elders.

De weefseldoorbloeding wordt geregeld door de samentrekking of verwijding van de gladde spiervezels in de wanden van de arteriolen: respectievelijk vasoconstrictie en vasodilatatie.

\subsubsection{NEURALE MECHANISMEN}

De overheersende invloed van het sympathisch zenuwstelsel bij de korte termijn controle die we vinden bij de hartregulatie, doet zich ook voor bij de 
regeling van de perifere weerstand. Alle bloedvaten, met uitzondering van de capillairen, worden geïnnerveerd door de sympathische zenuwvezels. Door sympathische stimulatie verandert de diameter van de vaten en daardoor de (perifere) weerstand. Dit heeft direct een verandering in de bloedstroom door de weefsels tot gevolg.

Bij bloeddrukveranderingen vervult het autonome zenuwstelsel eveneens een controlerende taak door middel van circulatoire reflexen. $Z o$ is een van de belangrijkste reflexen de baroreceptorreflex en de chemoreceptorreflex. De baroreceptoren zenden hun impulsen naar het hartregulatiecentrum (zie 1.4.1.1) en naar de medulla. In de medulla exciteren ze de kernen van de nervus vagus en inhiberen ze het vasomotorisch centrum. De resulterende effecten zijn:

1. Vasodilatatie in het perifere systeem.

2. Verminderde hartcontractie en verlaging van de hartfrequentie.

Daarom veroorzaakt stimulatie van de baroreceptoren door de druk in de arteriën reflexmatig een daling in de arteriêle druk. Bijgevolg geeft lage druk reflexmatig een verhoging van de druk naar het normale niveau. Het baroreceptor controlesysteem is echter niet van belang voor de regulatie van de arteriele druk op lange termijn. Dit ligt eenvoudig aan het feit dat de baroreceptoren zich vrij snel (binnen 2 tot 4 dagen) aampassen aan het drukniveau waaraan zij worden blootgesteld.

De chemoreceptoren zijn gelocaliseerd op dezelfde plaatsen en kunnen via dezelfde zenuwen als de baroreceptoren ook het vasomotorische centrum reflexmatig beïnvloeden. Als de zuurstofconcentratie te laag is worden ze geprikkeld en wordt via excitatie van het vasomotorisch centrum de arteriële bloeddruk verhoogd.

\subsubsection{HUMORALE FACTOREN}

De meest belangrijke humorale factor die de circulatie beinvloedt is het aldosteron dat wordt uitgescheiden door de cortex van de bijnier (Guyton e.a., 1974). Aldosteron regelt in belangrijke mate het bloedvolume. De secretie van aldosteron neemt automatisch toe, wanneer het extracellulaire vloeistofvolume, het bloedvolume, de zoutconcentratie of de cardiale output afnemen. De precieze oorzaak hiervan is echter nog niet duidelijk. Het aldosteron verhoogt de reabsorptie van natrium-ionen in de nieren zodat het extracellulaire vloeistofvolume en het bloedvolume weer zijn normale niveau krijgt. Ook de hormonen adrenaline en noradrenaline hebben een grote invloed op de circulatoire regulatie. Behalve een versterkte hartactiviteit veroorzaken zij ook een hogere perifere weerstand. Hun aanwezigheid in het bloed is van grote invloed op de weefseldoorbloeding: de arteriolen van skeletspieren en coronairvaten worden verwijd, terwijl de arteriolen in de huid en in de ingewanden zich vernauwen. 
Een andersoortige invloed op de bloeddruk heeft het hormoon renine, dat door de nieren wordt geproduceerd wanneer de bloeddruk over langere tijd een te sterke daling vertoont. Via verschillende tussenstappen waarin onder andere de hormonen angiotensine 1 en 2 worden aangemaakt, wordt een aangepaste vaatvernauwing tot stand gebracht zodat de bloeddruk weer stijgt (Guyton e.a., 1974). Ook binnen het renine-angiotensine systeem speelt sympatische activatie een belangrijke rol (Julius en Esler, 1975).

Chemische factoren tenslotte, kunnen eveneens invloed uitoefenen op de vaten. Het is echter een uiterst ingewikkeld poces en een bespreking ervan valt buiten de context van dit hoofdstuk.

\subsection{HET METEN VAN DE BLOEDDRUK}

De bloeddruk kan op invasieve en niet-invasieve wijze worden gemeten. De meest toegepaste (niet-invasieve) techniek staat bekend onder de naam RivaRocci. Er zijn electronische bloeddrukmeters verkrijgbaar waarbij men niet meer via een stethoscoop naar de Korotkoff-geluiden hoeft te luisteren, maar waarbij deze via een ingebouwde microfoon worden opgevangen en vervolgens zichtbaar worden gemaakt door middel van een lampje of een duidelijk hoorbaar signaal. De kwaliteit van de apparatuur is echter wisselend en regelmatige calibratie is wenselijk. Er bestaan ook diverse meettechnieken waarbij het mogelijk is gedurende langere tijd de bloeddruk te meten. $\mathrm{Zo}_{0}$ is er apparatuur ontwikkeld gebaseerd op de bekende Riva-Rocci-methode waarbij de registratie echter automatisch geschiedt (Cowan e.a. 1980, Onesti e.a., 1981, Godaert, 1986). Het apparaat is draagbaar en tijdens de registraties - die op gezette tijden plaatsvinden - kan men zijn dagelijkse activiteiten gewoon voortzetten. De metingen worden op een cassette vastgelegd. Het nadeel van deze 24-uurs registratie blijft echter dat ze ongemak veroorzaken doordat steeds een druk voelbaar is in de manchet rondom de bovenarm. Daarom is gezocht naar verkorting van de registratie-periode met behoud van zoveel mogelijk informatie. Weber e.a. (1982) hebben aangetoond dat de metingen van de bloeddruk geregistreerd tussen 8 en 10 uur 's ochtends goed correleren met het gemiddelde van de 24-uurs meting. De registraties werden echter verricht bij patiènten tijdens een verblijf in het ziekenhuis waarbij sprake was van een regelmatig dag en nachtprogramma. Godaert (1986) constateerde een goede overeenkomst tussen de gemiddelde druk van de 24uurs registratie en de metingen verricht tussen 11 en 13 uur en tussen 18 en 20 uur. In tegenstelling tot Weber e.a. (1982) voerden de patiënten in dit geval hun dagelijkse werkzaamheden uit. Er zijn echter ook andere meetmethoden die een nauwkeurige indicatie geven van de bloeddruk en die ongemerkt en gedurende langere tijd kunnen registreren. In samenwerking met Woestenburg heeft de auteur onderzoek verricht naar de geschiktheid van de voortplantingssnelheid van de drukgolf als indicatie voor de bloeddruk 
(Woestenburg, Schreurs, 1976; Steptoe, Godaert, Ross, Schreurs, 1983). Technische onvolmaaktheden verhinderen toepassing op ruimere schaal. Een andere continue (niet-invasieve) registratiemethode waarbij de technische ontwikkelingen wel verder gevorderd zijn, is "de methode Penâz": via een drukmanchet om de top van een vinger kan men vila plethysmografie een goede indicatie krijgen, via calibratie, van zowel de systolische, de diastolische en de gemiddelde arteriële druk. Voor verdere gegevens verwijzen we naar Wesseling e.a.(1982) en Godaert (1986).

Mede door deze geavanceerde meetmethoden is duidelijk geworden aan węlke grote schommelingen de bloeddruk dagelijks onderhevig is. Diverse omstandigheden kunnen de bloeddruk van moment tot moment veranderen.

Het vaststellen van 'de' bloeddruk is een ingewikkelde kwestie geworden omdat de condities zowel vooraf als tijdens de meting kunnen verschillen. Daarom streeft men ernaar om onder relatief 'rustige' omstandigheden de bloeddrukmeting te verrichten. Binnen de wetenschappelijke literatuur wordt deze meting een 'casual meting' genoemd: er worden geen ingrijpende voorbereidingen getroffen voor de meting. Door Montfrans (1984) is onderzocht in hoeverre deze meting voorspellend is met betrekking tot mortaliteit en morbiditeit.

De hoogte van de bloeddruk gemeten buiten het ziekenhuis bleek een betere voorspeller voor het ontstaan van hart- en vaatziekten dan de spreekuurbloeddruk volgens Montfrans (1984). De 'casual' metingen liggen echter ook ten grondslag aan de cijfers omtrent mortaliteit en morbiditeit die via de statistieken van levensverzekeringsmaatschappijen bekend zijn. Hierbij blijkt dat reeds bij betrekkelijk lage bloeddrukwaarden van rond 140/90 $\mathrm{mmHg}$ de sterftekansen toenemen. Bij een geringe bloeddrukverhoging van $160 / 95 \mathrm{~mm} \mathrm{Hg}$ is een oversterfte geconstateerd van 170 procent (Gezondheidsraad, 1983). Jaarlijks worden 40.000 Nederlanders getroffen door een hartinfarct en nog eens 20.000 door een herseninfarct waaraan vaak een periode van yerhoogde bloeddruk is voorafgegaan. Over de gevolgen van verhoogde bloeddruk op de gezondheid komen we in par. 1.8 uitgebreider terug. Allereerst is van belang om meer duidelijkheid te krijgen over de definierring van de begrippen 'normale' bloeddruk, alsmede 'lichte', 'belangrijke' en 'ernstige' bloeddrukverhoging.

\subsection{NORMALE BLOEDDRUK, 'LICHTE', 'BELANGRIJKE' EN 'ERNSTIGE' BLOEDDRUKVERHOGING}

Zoals besproken in 1.3, is de bloeddruk het resultaat van onder meer de hartfunctie, de perifere weerstand en het circulerend bloedvolume. Zowel bij gezonde mensen als bij degenen met hypertensie schommelt de bloeddruk vrij sterk. Al naar gelang de mate van lichaamsactiviteit is er een steeds veranderende behoefte aan bloedtoevoer. Bij spierarbeid bijvoorbeeld dient 
het weefsel meer doorbloed te worden dan in rust ${ }_{\text {s }}$ in verband met onder andere een grotere behoefte aan opbouwstoffen. Ook emotionele gebeurtenissen beînvloeden de bloeddruk sterk. Een ingewikkeld regelmechanisme maakt het mogelijk dat het lichaam zich aan de omstandigheden kan aanpassen.

Sokolow e.a. (1970) hebben onderzoek verricht naar de mate waarin bloeddruk-fluctuaties voorkomen. Door gebruik te maken van draagbare registratie-apparatuur werd aangetoond dat gedurende de dag schommelingen voorkomen van 40 a $60 \mathrm{~mm} \mathrm{Hg}$ voor de systole en van 15 a $20 \mathrm{~mm} \mathrm{Hg}$ voor de diastolle. Ook het onderzoek van Godaert (1986) laat zien dat er tijdens een 24-uurs registratie zich grote schommelingen van de bloeddruk voordoen.

Het grillige karakter van de bloeddruk maakt het erg moeilijk om over 'de' bloeddruk te spreken. Om van de bloeddrukhoogte een betrouwbaar beeld te krijgen moeten verscheidene metingen plaatsvinden en zo mogelijk op verschillende tijdstippen.

De frequentieverdeling van de bloeddruk in een populatie laat een uni-modale verdeling zien. Het is hierbij onmogelijk een duidelijke scheidslijn te trekken tussen normale en verhoogde bloeddruk. De afbakening van een te hoge bloeddruk kan derhalve slechts op arbitraire wijze plaats vinden.

Men dient tevens rekening te houden met de leeftijd, aangezien de bloeddruk de tendens vertoont te stijgen met de jaren. In de loop van het leven stijgt (in onze westerse samenleving) de bloeddruk meestal. Baby's hebben een systolische bloeddruk van 70 a $80 \mathrm{~mm} \mathrm{Hg}$. In de loop der eerste jaren stijgt deze langzaam en in de puberteit is de gemiddelde waarde van de systolische druk circa 110 en van de diastolische druk circa 70 à $80 \mathrm{~mm} \mathrm{Hg}$. Op 40-jarige leeftijd ligt de normale waarde op $125-135 \mathrm{~mm} \mathrm{Hg}$ voor de systole en $80-90$ $\mathrm{mm} \mathrm{Hg}$ voor de diastole.

In het adviesrapport inzake hypertensie wordt door de Gezondheidsraad (1983) de volgende indeling voorgesteld:

Een NORMALE BLOEDDRUK voor volwassenen bevindt zich in het gebied van 110 tot $140 \mathrm{~mm} \mathrm{Hg}$ voor de systole en van 70 tot $90 \mathrm{~mm} \mathrm{Hg}$ voor de diastole. Deze 'normale' bloeddruk zorgt ervoor dat het hart onder 'normale' omstandigheden zijn functie kan vervullen.

Van een 'LICHTE HYPERTENSIE' spreken we als de systolische druk ligt op het niveau tussen 140 en $160 \mathrm{~mm} \mathrm{Hg}$ en/of de diastolische druk tussen 90 en $100 \mathrm{~mm} \mathrm{Hg}$. In de Angelsaksische literatuur spreekt men in dit geval van 'borderline hypertensives'. Overigens willen we er hier op wijzen dat het onderscheid dat men vroeger pleegde te maken tussen labiele en stabiele hypertensie niet meer houdbaar is. De fysiologische variabiliteit en met name de schommelingen van de bloeddruk zijn immers groot bij zowel personen met een normale als een verhoogde bloeddruk.

Van een 'BELANGRIJKE HYPERTENSIE' is sprake bij een waarde vanaf 
$160 \mathrm{~mm} \mathrm{Hg}$ systolisch en/of een diastolissche druk tussen $100 \mathrm{en} 115 \mathrm{~mm} \mathrm{Hg}$. Tenslotte is er nog een categorie 'ERNSTIGE HYPERTENSIE". Hiervan is sprake wanneer bij herhaling een diastolische druk wordt gemeten van 115 $\mathrm{mm} \mathrm{Hg}$ en hoger.

\subsection{ESSENTIËLE EN SECUNDAIRE HYPERTENSIE}

Uit het voorafgaande moge blijken dat de arteriële bloeddruk wordt bepaald door een ingewikkeld regelmechanisme. Via een direct reagerend systeem kan de bloeddruk zich aanpassen aan de steeds wisselende omstandigheden. Naast het neurale regelmechanisme van de bloeddruk is er ook een langzamer reagerend systeem. Verschillende hormonen spelen hierbij een rol terwijl ook de nier nog via zijn invloed op de zout- en waterhuishouding een belangrijk effect op de bloeddruk heeft.

Ondanks een vergevorderd inzicht in dit regelmechanisme is de etiologie en de pathogenese van hypertensie echter nog verre van duidelijk. Het gecompliceerde mechanisme kan namelijk op verschillende plaatsen ontregeld worden. In 5 tot $10 \%$ van de gevallen van hypertensie kan een organische oorzaak worden geconstateerd. In dat geval spreken we dan van SECUNDAIRE HYPERTENSIE.

Enkele van deze bekende oorzaken van hypertensie zijn als volgt te rangschikken:

- Chronische nieraandoeningen,

- Hormonale afwijkingen, zoals

a. een overmaat aan noradrenaline en adrenaline vanwege een tumor van het bijniermerg of een deel van het sympatisch zenuwstelsel;

b. het syndroom van Conn, een overproductie van aldosteron tengevolge van een adenoom van de bijnierschors;

c. syndroom van Cushing, een teveel aan cortisol;

- Anatomische afwijkingen, zoals een aangeboren vernauwing van de aorta en vernauwingen van de nierarteriën,

- Overmatig dagelijks gebruik van drop dat glycyrrhizinezuur bevat, hetgeen zout- en waterretentie tot gevolg heeft,

- Invloeden van medicamenten: het gebruik van corticosteroiden, ergotamine-preparaten en adrenaline-achtige stoffen, kunnen de bloeddruk verhogen. Ook orale anti-conceptiva kunnen oedeem en bloeddrukverhoging veroorzaken. Tegenwoordig echter bevat de 'pil' veel minder oestrogeen (tot $37,5 \mathrm{mg}$ ) waardoor de kans op tensieverhoging veel geringer is.

Wij zullen ons echter uitsluitend richten op die vorm van hypertensie waarbij bovenvermelde oorzaken zijn uitgesloten. We spreken dan van ESSENTIËLE HYPERTENSIE.

Alvorens we nader zullen ingaan op de mogelijke oorzaken van essentiële 
hypertensie bespreken we kort enkele epidemiologische gegevens en de consequenties van hypertensie voor de gezondheid.

\subsubsection{EPIDEMIOLOGIE}

Als we bij volwassenen de bovengrens $140 / 90 \mathrm{~mm} \mathrm{Hg}$ aanhouden van wat de WHO een normale bloeddruk noemt (WHO/ISH Comittee,1983), dan hebben in Nederland $38 \%$ van de mannen en $35 \%$ van de vrouwen tussen 35 en 65 jaar een verhoogde bloeddruk. Zij lopen, volgens actuariële cijfers van epidemiologische studies en van verzekeringsmaatschappijen, een $50 \%$ verhoogde kans om in de komende 20 jaar te overlijden (Gezondheidsraad, 1983). Houden we een ondergrens voor de diastole aan van $100 \mathrm{~mm} \mathrm{Hg}$ dan blijkt dat ruim 275.000 mannen en 270.000 vrouwen in de leeftijdscategorie tussen 20 en 65 jaar deze grens te overschrijden. Voor beide sexen tezamen is dat ongeveer $12 \%$ van de totale bevolking. Boven het vijftigste jaar stijgt het aantal vrouwen met hypertensie uit boven dat van de mannen.

In figuur 1 zijn de gemiddelde bloeddrukwaarden naar leeftijd en geslacht weergegeven zoals yerkregen in het 'Epidemiologisch Preventief Onderzoek Zoetermeer' (Hofman e.a. 1980) waarbij ruim 10.000 personen van 5 jaar en ouder zijn betrokken.

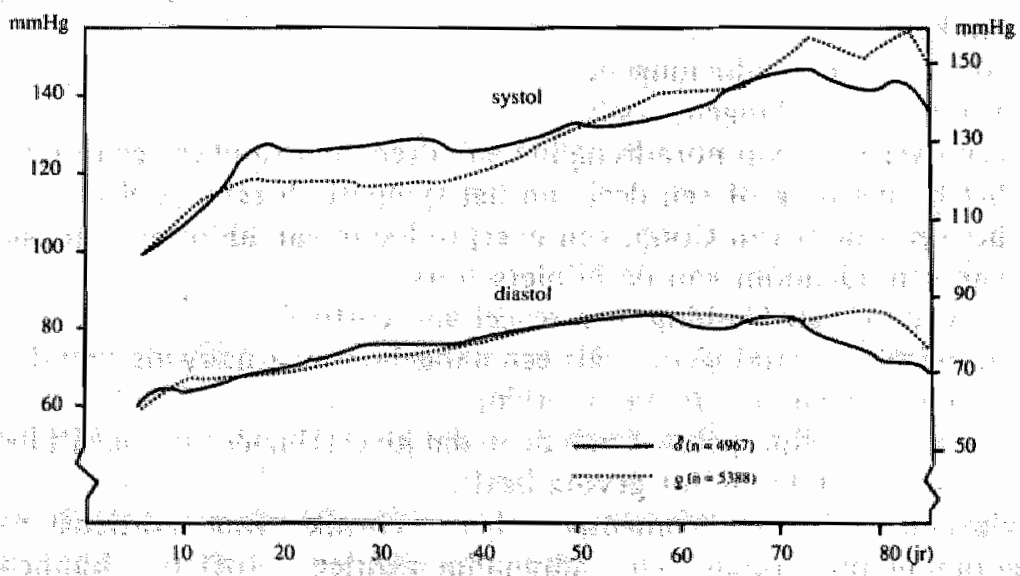

Fig. 1 Geslocht- en leefijdspectieke gemiddelden yan de systolische em diastolische (2) bloeddruk: $n=10.355$ (EPOZ 1978).

Uit ditzelfde bevolkingsonderzoek EPOZ en een onderzoek in Krimpen aan de IJssel (Prins, 1979) blijkt dat essentiële hypertensie erg vaak voorkomt.

In Zoetermeer vond men bij ongeveer 2500 mannen tussen de 20 en 65 jaar een percentage van 11,4 en bij ongeveer 3000 vrouwen in deze leeftijdsklasse een percentage van 9,7. In tabel 1 staan de resultaten van dit onderzoek samengevat. 
Ook in de leeftijdscategorie tot 21 jaar zijn de eijfers verontrustend: $5 \%$ van de jongens en $3 \%$ van de meisjes heeft een dusdanig hoge bloeddruk dat behandeling nodig wordt geacht (Hofman, e.a. 1980).

Tabel 1 . Verdeling natr geslacht en leeftijd van bloeddrukverhoughs boven dria verschillende grenswarden, buj in totad 10,355 awderzochten in Zoetermeer

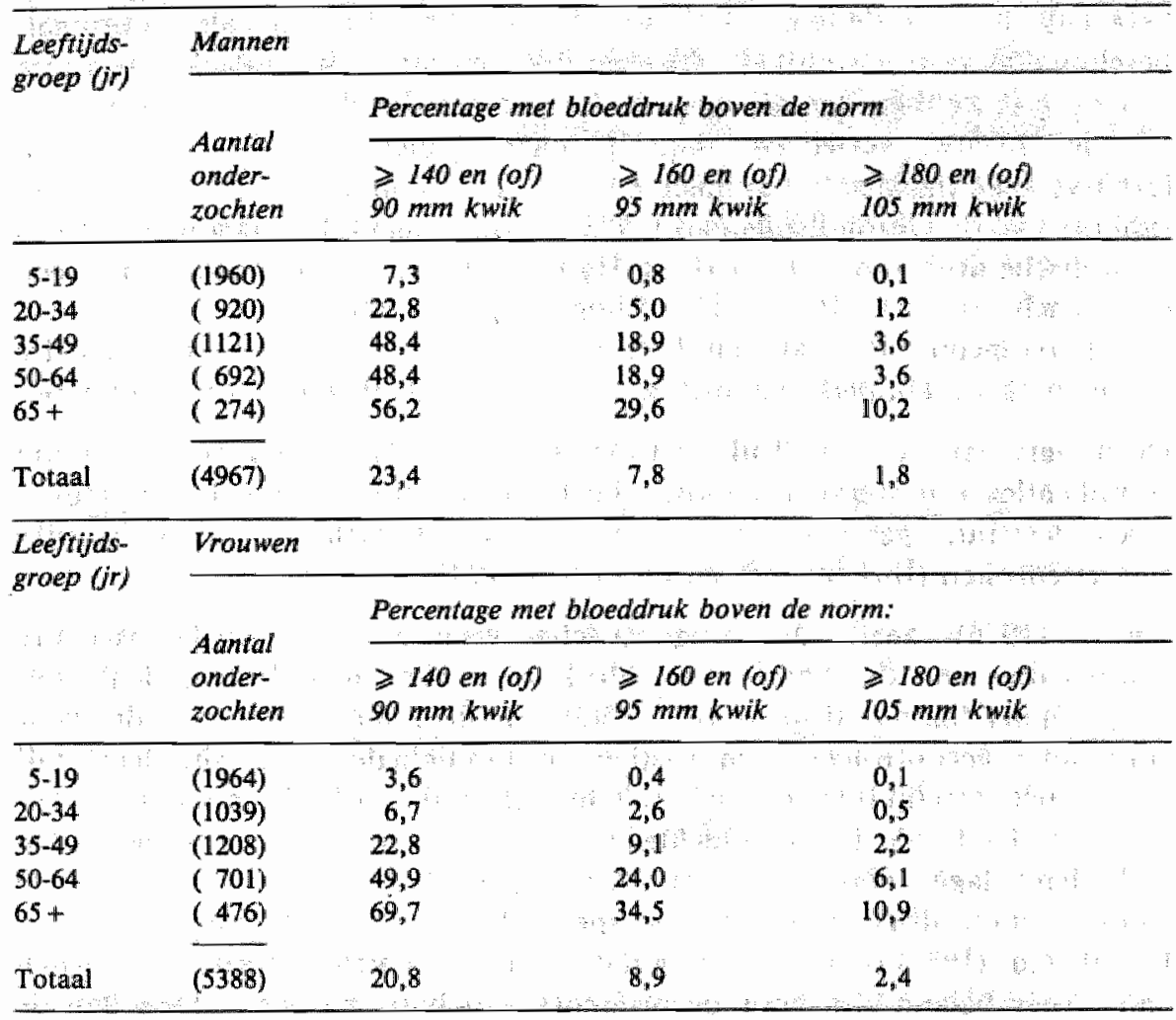

In het bevolkingsonderzoek in Krimpen a.d. IJssel vond men vergelijkbare cijfers: van de 3969 onderzochte mannen bleek $13,8 \%$ en van de 4705 vrouwen $9,1 \%$ een blceddruk te hebben die hoger was dan $160 / 95 \mathrm{~mm} \mathrm{Hg}$ (Prins, 1979).

De aanwezigheid van een verhoogde bloeddruk op jonge leeftijd is een belangrijke risicofactor voor het ontwikkelen van essentiële hypertensie op latere leeftijd. Van de personen bij wie op 20 -jarige leeftijd een licht verhoogde bloeddruk werd gemeten bleek dat bij het bereiken van de 40 jaar nog slechts $20 \%$ gediagnosticeerd kon worden als hypertensief (Julius 1978). Hoe hoger de bloeddruk op jongere leeftijd hoe groter de kans dat zich later hypertensie ontwikkelt. Enkele risicofactoren die deze kans vergroten zijn familiaire belasting, overgewicht en snelle hartslag. 


\subsubsection{HYPERTENSIE EN CONSEQUENTIES VOOR DE GEZONDHEID}

'Het inzicht in het belang van hypertensie wordt grotendeels bepaald door het gegeven dat iedere graad van bloeddrukverhoging een ongunstige betekenis heeft voor de gezondheidsvooruitzichten en de levensverwachting', schrijven Birkenhäger en de Leeuw (1985). Zelfs een gering verhoogde bloeddruk betekent een statistisch slechtere levenskans. Binnen als 'normaal' beschouwde waarden blijken diegenen met een lagere bloeddruk een betere prognose te hebben dan zij met een hogere bloeddrukwaarde. Birkenhäger en de Leeuw verwijzen daarbij naar ondermeer de cijfers van levensverzekeringsmaatschappijen en van de Framingham Studies. In het rapport van de Gezondheidsraad (1983) wordt gemeld dat personen met een diastolische druk van 95 tot $104 \mathrm{mmHg}$ ruim tweemaal, en personen met een diastolische druk van $105 \mathrm{mmHg}$ of hoger bijna viermaal meer de kans lopen de eerstvolgende 10 jaar een hartinfarct te krijgen of cerebrovasculaire aandoeningen, dan personen met een diastolische druk van 75 tot $84 \mathrm{mmHg}$.

De hoogte van de bloeddruk vertoont met betrekking tot cardiovasculaire complicaties een sterke prognostische interactie met andere risicofactoren zoals leeftijd, geslacht, ras, diabetes, overgewicht, alcoholmisbruik, sigarettenroken (Birkenhäger en de Leeuw, 1985).

Smirk (1976) heeft de prognostische waarde voor cardiovasculaire complicaties van de 'basale' bloeddruk vergeleken met de 'supplemental' druk. Onder "basale" druk wordt verstaan de druk die gemeten wordt onder zorgvuldig gecontroleerde en rustige omstandigheden. De 'supplemental' druk is het verschil tussen deze basale meting en de eerder besproken 'casual' gemeten bloeddruk. De gemiddelde levensverwachting van hypertensieven lag beduidend lager voor de groep met hogere basale waarden terwijl de 'supplemental' druk geen extra voorspellende waarde bleek te hebben. Door Perloff e.a. (1983) is erop gewezen dat ambulant gemeten bloeddrukwaarden van groter belang zijn voor de prognose van hart- en vaatziekten dan de 'casual' gemeten waarden. Hiermee zal toekomstig onderzoek op dit gebied rekening dienen te houden.

De schadelijke gevolgen van hypertensie kunnen worden toegeschreven aan veranderingen in de wand van de arteriën, arteriolen en het hart. De volgende veranderingen kunnen optreden:

a. De verdikking van de media (laag van glad spierweefsel en elastisch bindweefsel) kan als een direct gevolg van de hypertensie worden beschouwd. b. Bij een langbestaande hypertensie treedt arteriosclerose op. Hieronder verstaat men een verdikking van de wand van de arteriolen door afzetting van hyaline materiaal in de binnenste laag van de arteriolen. Arteriosclerose komt in het gehele lichaam voor.

c. Arteriolen in de hersenen kunmen yerwijdingen vertonen. De kans hierop is sterk afhankelijk van de leeftijd van de patient en de hoogte van de 
diastolische bloeddruk. De plaatselijke verwijdingen van deze arteriolen kunnen hersenbloedingen veroorzaken.

d. De gevolgen voor het hart kunnen van tweeërlei aard zijn:

Doordat bij iedere hartslag het hart een hogere druk moet overwinnen (hoger dan de druk die normaal nodig is in de linkerventrikel) om de aortakleppen te openen, kan dit tot arbeidshypertrofie van het myocard leiden hetgeen een decompensatie van het hart tot gevolg kan hebben.

Door de hypertensie wordt ook coronair-sclerose bevorderd wat tot angina pectoris en een hartinfarct kan leiden. 


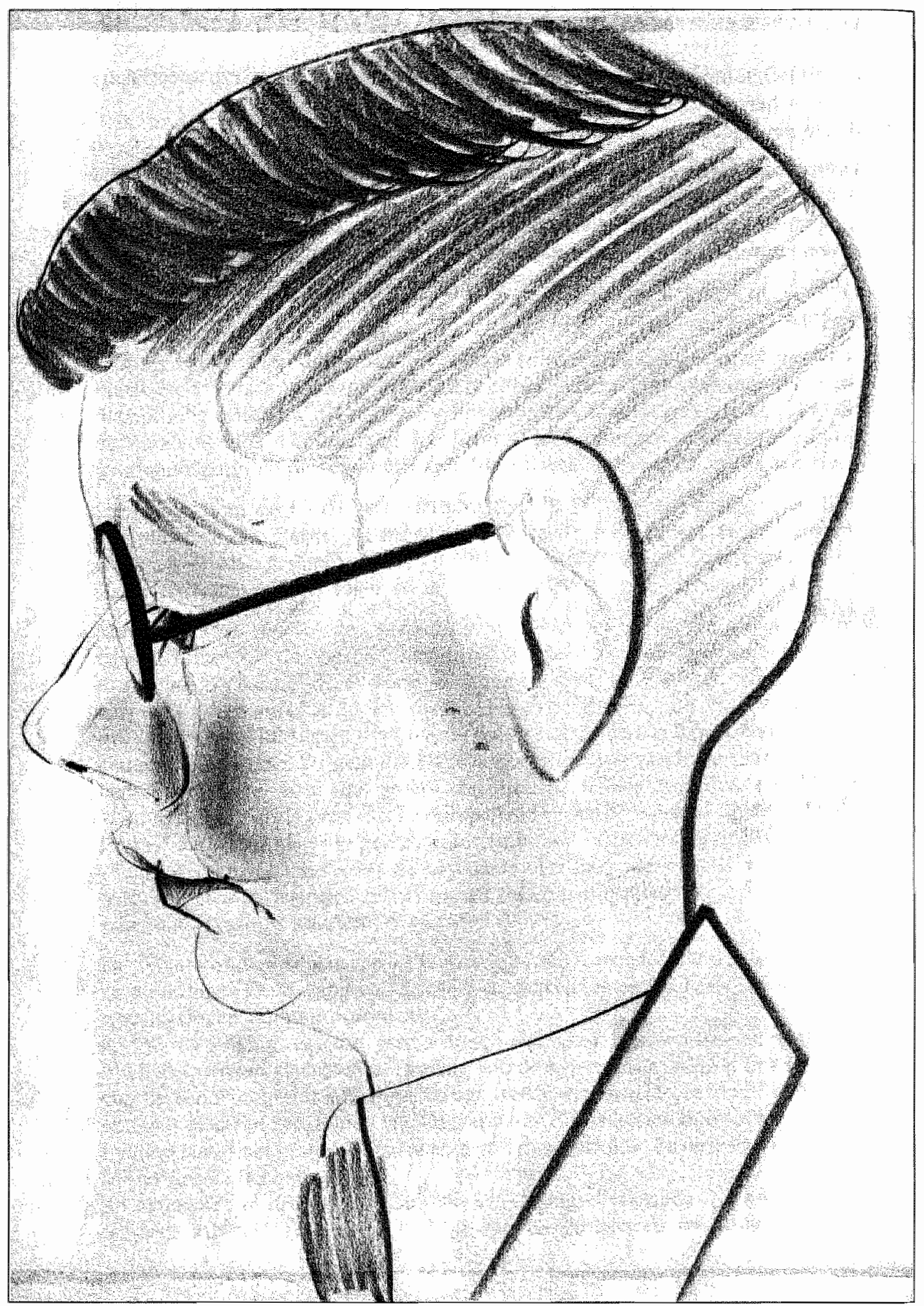




\section{HOOFDSTUK 2}

\section{ESSENTIËLE HYPERTENSIE}

\subsection{RISICOFACTOREN}

In tegenstelling tot de in paragraaf 1.7 genoemde oorzaken van secundaire hypertensie is er bij essentiële hypertensie per definitie (nog) geen direct aanwijsbare organische oorzaak. Volgens Pickering (1973) is er slechts sprake van een kwantitatief verschil waarbij essentiële hypertensie op te vatten is als niets anders dan de bovenste uitloper van de frequentieverdeling van de bloeddrukwaarden in de bevolkingspopulatie. Andere onderzoekers zijn daarentegen van mening dat hypertensie-patiënten zich als een aparte populatie onderscheiden (Platt, 1959; Guyton e.a., 1974; Esler e.a., 1977).

Niet alleen de vraag hoe, maar ook de vraag waardoor hoge bloeddruk ontstaat, is niet met zekerheid te beantwoorden. Algemeen wordt aangenomen dat er sprake is van een ingewikkelde interactie tussen erfelijke en andere factoren, hetgeen met het vorderen der leeftijd tot uiting komt in hoge bloeddruk. Van deze laatste groep factoren is het gebruik van zout waarschijnlijk erg belangrijk. Verder kan overgewicht een belangrijke bijdrage leveren aan de ontwikkeling van hypertensie. Ook de aanwezigheid van andere risicofactoren voor cardiovasculaire complicaties kunnen van invloed zijn op de bloeddruk zoals relatief lichaamsgewicht, cholesterolniveau, glucosegehalte en het roken van sigaretten. Door Stamler e.a. (1975) worden vier omvangrijke epidemiologische studies met elkaar vergeleken. Er wordt geconcludeerd dat maximaal 20 tot 25 procent van de intra-individuele variabliteit in bloeddruk verklaard kan worden door de hierboven genoemde variabelen.

Een andere risicofactor die steeds meer genoemd wordt in de betreffende literatuur is 'stress'. Het wordt aannemelijk geacht dat er een verband bestaat tussen de wijze waarop men reageert op bepaalde ongevingsfactoren zoals ernstige gebeurtenissen of problemen en het ontstaan van hoge bloeddruk. Dit verband is echter nog lang niet volledig opgehelderd. We zullen hier uitgebreider op terugkomen.

\subsubsection{ERFELIJKHEID}

Al jaren lang probeert men met behulp van familie-onderzoek de bijdrage van erfelijke factoren in kaart te brengen (Feinleib, 1979). Daaruit komt naar voren dat de bloeddrukwaarden van nabije bloedverwanten in zekere mate onderling overeenstemmen. Dit geldt als men ouders en kinderen met elkaar 
vergelijkt en ook als men generatiegenoten onderling vergelijkt. Hierbij is het niet van belang of zij al dan niet hetzelfde milieu delen. Ook de bloeddrukwaarden wan twee-eiige tweelingen vertonen een zekere mate van onderlinge overeenstemming. Eeneiige tweelingen hebben sterk overeenkomende bloeddrukwaarden.

Als men daarentegen de bloeddruk vergelijkt tussen echtgenoten, tussen ouders en adoptief kinderen, adoptief kinderen en natuurlijke kinderen of tussen adoptief kinderen onderling, dus groepen die wel eenzelfde omgeving delen maar verschillende erfelijke eigenschappen hebben, dan blijkt er een veel geringer verband te bestaan. Feinleib (1979) komt tot de conclusie dat tot $60 \%$ van de bloeddrukvariantie in een populatie, verklaard kan worden door genetische factoren.

Hypertensieven hebben vaker ouders met hypertensie. De kinderen van hypertensieve ouders hebben volgens Kaplan (1980) een tweemaal zo grote kans op hypertensie dan kinderen van normotensieve ouders.

Ook Hastrup e.a. (1982), Manuck e.a. (1982) en Jörgenson e.a. (1981) wijzen op de belangrijke invloed van erfelijke factoren. Op het eerste gezicht duiden deze bevindingen erop dat erfelijke factoren belangrijker zijn dan omgevingsfactoren. Men hoede zich echter voor voorbarige conclusies omdat de invloed van de ouderlijke hypertensie op de bloeddruk van de kinderen sterk verweven is met zowel erfelijke als omgevingsfactoren. We gaan hierop verder in bij de bespreking van de macro sociale omgeving in relatie tot hypertensie (par.2.2).

Dat erfelijke factoren van belang zijn staat wel vast, al is niet bekend welk gewicht zij in de schaal leggen en hoe zij hun invloed doen gelden. Het laat zich aanzien dat een erfelijke aanleg voor hoge bloeddruk alleen niet voldoende is en dat voor het tot uiting komen van de hoge bloeddruk meer factoren aanwezig moeten zijn.

\subsubsection{ZOUT}

De hoeveelheid zout $(\mathrm{NaCl})$ die het menselijk lichaam nodig heeft om in zeer uiteenlopende omstandigheden te kunnen functioneren, is uiterst gering. Deze wordt geschat op 2 gram per dag, terwijl de gemiddelde dagelijkse zoutconsumptie in de westerse wereld ongeveer 10 tot 15 gram bedraagt. Epidemiologische onderzoekingen tonen aan dat bij bepaalde bevolkingsgroepen bijna geen hoge bloeddruk voorkomt. Bij deze groepen doet zich, het in westerse landen zo 'normale' verschijnsell dat de bloeddruk stijgt naarmate men ouder wordt, niet voor. De systolische druk blijft bij volwassenen op een niveau omtrent $125 \mathrm{~mm} \mathrm{Hg}$, ook bij de ouderen. Deze waarnemingen deed men bij verschillende bevolkingsgroepen, onder meer in Oceanië, Alaska en Groenland, het Amazonegebied, Tanzania en Kenya 
(Scotch en Geiger, 1963; Marmot 1984). De meest sluitende verklaring voor het ontbreken van de bloeddrukstijging met de leeftijd en voor het nagenoeg niet voorkomen van hoge bloeddruk is dat de betreffende groepen heel weinig of geen zout aan hun woedsel toevoegen, namelijk niet meer dan drie gram of minder (Joossens, 1980).

Ook door middel van dier-experimenteel onderzoek werd de relatie tussen zoutgebruik en hypertensie aangetoond (Dahl e.a., 1962). Het al dan niet optreden van hypertensie bleek afhankelijk te zijn van de erfelijke aanleg plus het zoutgebruik. De proeven maakten verder duidelijk dat naarmate de dieren op jongere leeftijd aan zoutbelasting werden blootgesteld, zij des te gevoeliger waren voor het ontstaan van een snel en ernstig verlopende bloeddrukstijging.

Een te hoge zoutconsumptie alleen behoeft dus geen causale factor te zijn voor hypertensie. Het gegeven dat bij een groep Boeddhistische monniken, die dagelijks veel zout gebruiken ( 20 gram), geen verhoogde bloeddruk werd aangetroffen kan hiervoor ter adstructie dienen (Henry en Stephens, 1977). Het is eerder te verwachten dat er sprake is van een interactie-effect tussen genetische factoren (gevoeligheid voor zout) en aanwezigheid van psychosociale factoren (stress). Dier-experimenteel onderzoek heeft aangetoond dat rattenstammen kunnen verschillen in hun gevoeligheid voor zoutopname (Dahl e.a., 1962).

Door Friedman en Dahl (1975), Friedman en Iwai (1976) en Schneiderman (1983) wordt echter aangetoond dat een blootstelling aan allerlei psychosociale stressoren en tevens een toediening van hoge zoutconcentraties tot hypertensie leidt bij die ratten die, erfelijk gezien, gevoelig waren voor zout. Het is mogelijk dat een dergelijk interactie-effect ook bij mensen kan worden aangetroffen.

\subsubsection{OVERGEWICHT}

Een andere factor die bij het ontstaan van hoge bloeddruk van belang kan zijn, is overgewicht. Bij nagenoeg alle onderzoeken naar de relatie tussen bloeddruk en rellatief lichaamsgewicht vindt men binnen een populatie een significant positieve, van andere factoren onafhankelijke relatie die sterker is bij jongeren dan bij ouderen (Kannel e.a., 1967; Stamler e.a., 1978; Joossens, 1980).

Een maat om overgewicht te bepalen is de index van Quetelet. Deze indlex is te berekenen door het gewicht te delen door het kwadraat van de lengte.

In figuur 2 zien we de geslacht- en leeftijdspecifieke gemiddelden van de Quetelet-index van de onderzoekspopulatie in het EPOZ-onderzoek (Valkenburg e.a., 1980). 


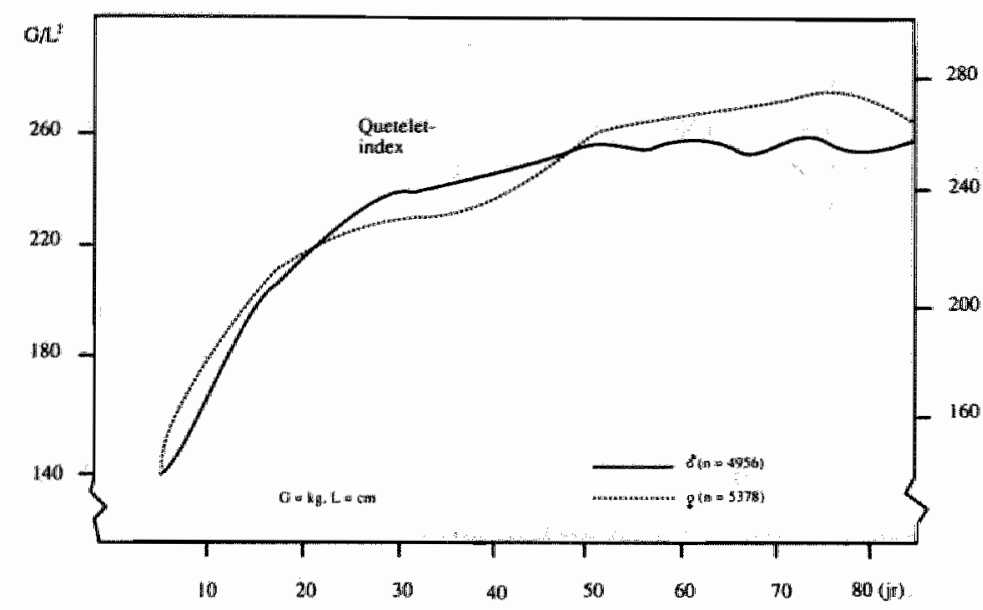

Fig. 2. Geslacht-en leefijidspecifieke gemiddelden van de Quetelet-index $\left(10^{5} \times \mathrm{G} / \mathrm{L}^{2}\right) ; \mathrm{n}=10.334$ (EPOZ 1:978).

Het verloop van de gemiddelde Quetelet-index komt overeen met dat van de systolische bloeddruk. Tussen 5 en 20 jaar stijgt de index sterk. Vanaf het $22 \mathrm{e}$ jaar tot het $45 \mathrm{e}$ jaar zijn de mannen gemiddeld zwaarder dan de vrouwen; daarna hebben de vrouwen een relatief overgewicht.

Het is regelmatig aangetoond dat mensen met overgewicht vaker hypertensie hebben dan mensen met een normaal gewicht en dat overgewicht op jonge leeftijd een substantiële prediktieve waarde heeft (Miller en Shekelle, 1976 en Pickering e.a., 1982). Chiang e.a. (1969) toonden aan dat personen die sterk in lichaamsgewicht toenemen een grotere kans hebben op het ontwikkelen van hypertensie. Ook de resultaten van het Framingham onderzoek (Kannel, 1973,1981) wijzen in deze richting. Toch is het zo dat uiteraard niet iedereen met een overgewicht ook een hypertensie heeft of zal ontwikkelen in de naaste toekomst. Ook voor deze risicofactor geldt dat er een ingewikkelder samenspel van allerlei factoren verwacht mag worden (Dressler, 1983).

Mensen met zowel overgewicht als hypertensie kunnen in de meeste gevallen een redelijke bloeddrukdaling verwachten als zij minstens drie kilo afvallen. In een recent gepubliceerd onderzoek (New England Journal of Medicine, febr, 1986) is vastgesteld, dat gewichtsvermindering een opvallende uitwerking op de bloeddruk kan hebben. Het onderzoek omvatte 41 te zware personen met een te hoge bloeddruk, 29 mannen en 12 vrouwen tussen 20 en 55 jaar. De diastolische druk lag tussen 90 en $109 \mathrm{~mm} \mathrm{Hg}$, hun quetelet-index lag veelal hoger dan 270 (voor mannen) en 250 (voor vrouwen). De diastolische en de systolische bloeddruk daalde substantieel tot praktisch normale waarden, indien men erin slaagde via een streng dieet aanzienlijk af te vallen. Een opzienbarend resultaat was dat de massa van het vergrote linkerhartventrikel eveneens sterk afnam. Deze afname van de spiermassa kan volgens de auteurs 
voor een groot deel aan de algehele gewichtsvermindering worden toegeschreven.

\subsubsection{ALCOHOL}

Door verschillende onderzoekers is er een correlationeel verband aangetoond tussen alcoholgebruik en bloeddruk (Friedman e.a. 1982 en Hofman e.a. 1985). Door Hofman wordt 5\% van de gevallen van hypertensie aan alcoholgebruik toegeschreven. Bloeddrukwaarden van $160 / 95 \mathrm{~mm} \mathrm{Hg}$ of hoger komen tweemaal zo vaak voor bij personen die 5 of meer alcoholische consumpties per dag nemen.

\subsubsection{STRESS}

Er is een groeiend aantal publicaties die de rol van 'stress' in de etiologie van hypertensie onderzoekt. De veronderstelling dat 'stress" en hypertensie op de een of andere manier verband houden, vinden we reeds bij Alexander (1939). De reden dat de discussie over de etiologische betekenis van stress nog volop aan de gang is ligt enerzijds aan het feit dat het hemodynamische verloop van essentiële hypertensie verschillend van aard is en anderzijjs aan de talrijke definities dat het begrip 'stress' kent (Kleber, 1982): Stress wordt gezien als een fysiologische reactie, als kwaliteit van een gebeurtenis en als resultaat van een interactie tussen persoon en omgeving.

Lazarus (1966) onderkende reeds lang dat stress op verschillende manieren gedefinieerd kan worden en dat dit niet bevorderlijk is voor een beter begrip van de mogelijke rol in de etiologie van hypertensie. Hij concludeert:

"It seems wise to use "stress" as a generic term for the whole area of problems that includes the stimuli producing stress reactions, the reactions themselves and the various intervening processes..... As used here it will be nothing more than a general label like motivation or cognition. It defines a large, complex, amorphous, interdisciplinary area of interest and study' (p.27).

Volgens de recente opvattingen wordt stress niet langer beschouwd als een aanpassing-vereisende gebeurtenis, noch als een psychologische of fysiologische reactie, maar als een relationeel begrip, een samenspel tussen de waargenomen eisen en bedreigingen vanuit de omgeving en het vermogen van het individu om daaraan tegemoet te komen. Deze aanpassing gaat gepaard met een bepaalde fysiologische activiteit. Ook de bloeddruk speelt hierbij een belangrijke rol. Zoals gesteld in hoofdstuk 1 vindt de bloeddruk-regulatie plaats op tweeërlei wijze: een langzaamwerkende volumeregulatie en een snelwerkende vasoregulatie. De bloeddruk-regulatie past zich zeer nauwkeurig aan aan de eisen die de omgeving of situatie aan iemand stelt. Zowel fysieke stimuli, bijvoorbeeld lawaai en temperatuurschommelingen als ook psychologische stimuli, zoals het denken aan een examen of een bezoek aan 
de tandarts kunnen een aanpassing van de bloeddruk veroorzaken. Deze vaak tijdelijke verhogingen (fasische veranderingen) zijn zeer functioneel. $\mathrm{Zij}$ stellen iemand in staat om adekwaat met de situatie om te gaan. In deze toestand van verhoogde alertheid vindt naast een verhoging van de bloeddruk ook een verhoogde energiemobilisatie plaats. De suikerspiegel en de bloedlipiden (o.a. cholesterol) worden verhoogd, er is een toename van adrenaline waardoor een hogere hartfrequentie wordt bereikt, zodat de skeletspieren van meer energie kunnen worden voorzien.

In eerste instantie is dit een nuttig aanpassingsproces. Er kunnen allerlei cognitieve en gedragsmatige acties worden ondernomen om de spanningoproepende situatie te wijzigen of te laten verdwijnen (= "copinggedrag"). Bij het tekortschieten van dit copinggedrag waardoor de bedreigende, vervelende situatie blijft aanhouden treden er allerlei fysiolgische reacties op die op den duur schadelijk kunnen zijn.

Het vermoeden bestaat dat het herhaaldelijk en/of langdurig optreden van deze verhoogde fysiologische activiteit (met name van het sympatische zenuwstelsel) op den duur tot chronische veranderingen van het cardiovasculaire systeem kunnen leiden en daarmee tot een blijvende hypertensie (Kaplan, 1978, Folkow e.a.1966, 1977). Von Uexküll (1964) wees eveneens reeds op de mogelijkheid van een chronisch worden van de hypertensie door een aanpassing van de pressorreceptoren (= baroreceptoren) aan de verhoogde bloeddrukwaarden ten gevolge van emotionele stress of door inschakeling van de renine-angiotensinekringloop bij vaatspasmen van de nier.

In dit verband zijn de onderzoekingen van Sheperd (1981) van belang waarbij werd vastgesteld dat bij emotionele stress een zekere weerstandsverhoging van de niervaten optreedt, waarbij een verhoogde renine-productie tot stand komt. Dit enzym renine zet het in de bloedeiwitten aanwezige angiotensine in angiotensine II om, wat tenslotte een verhoogde systolische en diastolische bloeddruk teweeg brengt. Ook Julius en Esler (1975) hebben opgemerkt dat het renine-angiotensine systeem onder grote invloed staat van de sympatische activiteit.

Het verband tussen stress en hypertensie wordt middels een aantal onderzoekslijnen duidelijk aangetoond:

\section{a. Dier-experimenteel onderzoek.}

Dier-experimenten hebben aangetoond dat via herhaaldelijk oproepen van de zogenaamde "defensie-reactie" waarbij bloeddrukverhoging (zowel tonisch als fasisch) optreedt, na verloop van tijd een blijvende hypertensie ontwikkeld wordt (Henry e.a. 1967, 1975). Er vinden onomkeerbare vaatveranderingen plaats waardoor de bloeddruk hoog blijft. Door een langdurige blootstelling aan een grotere druk gaat de vaatwand dikker worden, zo betogen Folkow 
e.a. (1977). Hierdioor worden ook de vasoconstrictieve eigenschappen van de vaatwand veranderd. Gedurende fluctuaties van de bloeddruk zal de vaatwand dan veel sterker contraheren dan voorheen. Ook kunnen structurele veranderingen leiden tot een verandering van de verhouding vaatwand/lumen.

Door Dahl e.a. (1962) werd er op gewezen dat de blijvende verhoging van de bloeddruk zich vooral voordeed bij ratten met een genetische predispositie die na zoutopname sterk reageerden met de bloeddruk. De 'defensie-reactie' kan experimenteel worden opgeroepen door electrische stimulatie van de hypothalamus (Folkow e.a., 1982) of indirect binnen een zogenaamde "shockavoidance" opstelling of een situatie van 'overbevolking' (Henry, Stephens, 1977).

Door Koolhaas e.a. (1983) is aangetoond dat het regelmatig 'opjagen' van de bloeddruk bij ratten via allerlei 'sociale' prikkels uiteindelijk tot hypertensie kan leiden. $\mathrm{Zij}$ bestudeerden daartoe het territoriumgedrag van mannetjesratten. Over het algemeen vertoonden de meest agressieve ratten ook het meest actieve verdedigingsgedrag en hadden zij de heftigste bloeddrukreacties. Het ontwikkelen van een permanent verhoogde bloeddruk bleek echter af te hangen van de positie binnen de groep ratten. De 'machtigste" rat die nooit een territorium-gevecht verloor, ontwikkelde geen hypertensie en ook geen andere lichamelijke klacht. Het waren met name de subdominante ratten die hypertensie ontwikkelden: zij hadden veel geldingsdrang en moesten vaak vluchten. Passief ingestelde ratten daarentegen hielden een normale bloeddruk. De echte verliezers, helemaal onderaan in de hiërarchie, die het steeds weer opnieuw moesten ontgelden, kregen geen hypertensie maar ontwikkelden wel in enkele gevallen maagzweertjes.

b. Hypertensie in verschillende beroepsgroepen.

Er zijn aanwijzingen dat hypertensie vaker voorkomt in enkele beroepsgroepen zoals vliegverkeersleiders (Cobb, 1973), telefonistes (Miasnikov, 1961), bus en tramchauffeurs (Holme e.a., 1977) en gevangenbewaarders (Kalimo, 1980). Deze onderzoeken suggereren dat het onder een permanente (mentale) spanning staan kan leiden tot een hogere prevalentie van hypertensie. In hoofdstuk 3 zullen we hier nader op ingaan.

\section{c. Macro-sociale factoren.}

Binnen leefgemeenschappen waarin traditionele vormen hoog worden geprezen en er sprake is van veiligheid en cohesie, stijgt de bloeddruk meestal niet met de leeftijd en is de bloeddruk over het algemeen lager dan in andere culturen. Emigreren deze mensen echter naar een meer geïndustrialiseerde samenleving dan stijgt de bloeddruk sterk en komt vaker hypertensie voor (Cassel, 1974).

In paragraaf 2.2 worden enkele socio-culturele studies nader besproken. 


\section{d. 'Life events onderzoek'.}

In enkele overzichtsartikelen (Gutman en Benson 1971, Shapiro en Goldstein 1982, Harrell 1980) wordt duidelijk het verband aangetoond tussen het meemaken van stressvolle gebeurtenissen en hypertensie. In deze artikelen wordt aannemelijk gemaakt dat aanpassing-vereisende gebeurtenissen een rol spelen in de etiologie van essentiële hypertensie. Zo is gebleken dat gedurende het meemaken van een orkaan, oorlogsituatie en andere ernstige situaties de bloeddruk langere tijd verhoogd kan zijn, hetgeen mogelijk tot hypertensie aanleiding kan geven. Over het proces dat aan deze relatie ten grondslag ligt, bestaat nog weinig overeenstemming. Onduidelijk is in welke mate andere factoren een modererende werking hebben zoals de sociale context waarin een bedreigende gebeurtenis zich afspeelt, persoonlijkheidskenmerken en sociale steun. Dit onderzoek is nog in volle gang.

In de volgende paragrafen zullen we nader ingaan op een aantal psychosociale factoren die hierboven reeds kort zijn aangehaald. Uitvoerig wordt ingegaan op onderzoeksresultaten betreffende persoonlijkheidskenmerken die in verband worden gebracht met essentiële hypertensie.

Lazarus (1980) heeft er op gewezen dat de verschillen in fysiologische reacties gedeeltelijk te verklaren zijn door de wijze waarop men gebeurtenissen en problemen waarneemt en ermee omgaat. Hierbij zijn naast de aard van de gebeurtenissen en problemen ook persoonsgebonden eigenschappen van belang. Deze onderzoekslijn zal in hoofdstuk 3 uitgebreider aan de orde komen.

\subsection{SOCIALE OMGEVING}

'Hypertensie, een ziekte van de moderne samenleving', schrijft Eyer (1975). Volgens hem is essentiele hypertensie een ziekte die alleen voorkomt in moderne samenlevingen, zoals bijvoorbeeld in West Europa, de Verenigde Staten, Taiwan, Japan en ook in alle Oost-bloklanden. Welke faktoren zijn er nu verantwoordelijk voor deze stijging van de bloeddruk? Eyer (1975) noemt er twee:

1. Verstoring van de kleinere sociale netwerken;

2. Hiërarchisch gecontroleerd en onder tijdsdruk uitgevoerd werk.

Deze factoren zijn volgens Eyer essentiële kenmerken van het modernisatieproces dat verbonden is aan de industriële samenleving en geen toevallige bijverschijnselen. Een nevenverschijnsel als de grootscheepse migratie naar de steden kan ook nog genoemd worden in dit verband. De hierdoor veroorzaakte populatiedichtheid vergroot de kans op intermenselijke conflicten en territoriumstrijd.

Ook Hinkle (1973) schrijft de toename van zogenaamde 'stress-ziekten' toe aan de moderne samenleving, vooral aan de toegenomen complexiteit van de 
maatschappij in termen van sociale en interpersoonlijke relaties. Sociale relaties stellen vaak veel eisen aan het individu en kunnen daardoor een bron vormen van conflicten. Mensen worden voortdurend gedwongen veel van hun directe behoeftes en verlangens uit te stellen of te verhullen ten behoeve van het sociale netwerk waarvan ze deel uitmaken. Dit zou volgens Hinkle verantwoordelijk kunnen zijn voor de stijging van de bloeddruk met de leeftijd die zo kenmerkend is voor de moderne samenleving.

In hoofdstuk 1 bespraken we, dat over het algemeen gesteld, de bloeddruk stijgt naarmate men ouder wordt. Dit is echter niet altijd het geval. Uit epidemiologisch onderzoek (zie Henry en Stephens, 1977) blijkt dat de bloeddruk van mensen die leven in stabiele culturen niet altijd stijgt met de leeftijd. Het betreft hier dan leefgemeenschappen waarin traditionele vormen nog hoog geprezen worden en de meeste mensen een duidelijke en omlijnde rol vervullen in de gemeenschap en zich daarbij zeker en veilig voelen. Dat de bloeddruk van deze mensen niet altijd stijgt met hun leeftijd kan slechts gedeeltelijk verklaard worden door een lagere zoutconsumptie binnen deze culturen; het is waarschijnlijk dat psychologische factoren een belangrijker rol spelen. Ook binnen westerse landen zijn groepen mensen te onderscheiden waarbij de bloeddruk geen stijging vertoont met het voortschrijden der jaren (Jenkins e.a., 1983). Zij analyseerden bloeddrukgegevens, gemeten gedurende 14 achtereenvolgende jaarlijkse medische keuringen van 172 voornamelijk blanke employees. Het bleek dat slechts bij de helft van de mensen de bloeddruk geleidelijk met het stijgen der jaren toenam. Bij de andere helft was dat dus niet het geval:

'it seems that acknowledgment of stress and distress may be a characteristic of people whose blood pressure does not increase systematically with age" (Jenkins e.a. 1983,p 11).

Ook in een onderzoek bij vliegverkeersleiders treft hij aan dat vooral bij die mensen die rapporteren geen 'stress' te ervaren, een stijging van de bloeddruk wordt gemeten. In hoofdstuk 3 komen we hier nader op terug.

Evenmin kan gesteld worden dat essentièle hypertensie uitsluitend in geindustrialiseerde landen voorkomt. Ook in zogenaamde onderontwikkelde landen is dat het geval. In Ghana bijwoorbeeld komt essentiële hypertensie bijna even vaak voor als in Nederland. Ook bij de negerbevolking van Panama komt essentiële hypertensie ongewoon vaak voor. Dit gegeven ontkracht dan weer gedeeltelijk de eerdere verklaringen van Eyer (1975) en Hinkle (1973) betreffende hypertensie als ziekte van de moderne samenleving.

Verschillende publicaties (Scotch en Geiger 1963, Syme e.a., 1974) geven aan dat bij de negerbevolking in bepaalde delen van de Verenigde Staten en met name in de grote steden vaker essentiële hypertensie voorkwam dan bij de plaatselijke blanke bevolking. De verklaring hiervoor kon niet worden gezocht in eet- en leefgewoonten. 
Er zijn ook bloeddrukverschillen geconstateerd tussen de stedelijke en de plattelandsbevolking. Zulu's die in steden woonden hadden veelal een hogere bloeddruk dan Zulu's die op het platteland woonden. Scotch (1961) merkt in dit geval echter op dat deze verschillen in bloeddruk niet simpelweg verklaard kunnen worden door culturele aspecten of gevolgen van urbanisatie. Een cruciale factor die meebepaalt of stedelijke Zulu's hypertensie ontwikkelen is, het ervaren van moeilijkheden met de leefgewoonten in een stad. De Zulu's die zich goed konden aanpassen ontwikkelden veel minder vaak essentiële hypertensie.

Over de gevolgen voor hypertensie van migratie van een landelijke omgeving naar een meer Westerse en geürbaniseerde omgeving is veel onderzoek. verricht. Herhaaldelijk wordt aangetoond dat bij diegenen die geëmigreerd zijn de bloeddruk sterker stijgt dan bij de 'thuisblijvers'. In het overzichtsartikel stelt Marmot (1984) dat de zogenaamde "urbanisatie-theorie" niet altijd van kracht is. De cardiovasculaire veranderingen die mogelijk optreden kunnen ook het gevolg zijn van andere eetgewoonten en verminderde lichaamsbeweging. Mann (1986) wijst in dit verband nog op een andere mogelijke 'verstoorder' van de relatie emigratie en hypertensie: ...'migration is not a random event and there may be hidden selection factors among the migrants'. (pag. 530)

Onderzoek is eveneens verricht naar mogelijke verbanden tussen hypertensie en sociaal-economische klasse. Volgens het survey-onderzoek van Harburg e.a. $(1973,1979)$ uitgevoerd in de Verenigde Staten komt in de lagere sociaaleconomische klassen een relatief hoge frequentie van hypertensie voor. Dit kan volgens de auteurs verklaard worden door armoede en slechtere medische verzorging.

In enkele studies zoals die van Dyer e.a. (1976), Holme e.a. (1976), werden echter geen positieve correlaties gevonden tussen hypertensie en sociaaleconomische klasse, inkomen of opleiding.

Ook in de Framingham studies treft men geen werschil in bloeddruk aan tussen bepaalde beroepsgroepen. Wel was er een gering verschil in opleidingsniveau: hoger opgeleide mensen hebben een iets lagere bloeddruk (Kannel, 1973).

Stamler e.a. (1967) toonden aan dat de mortaliteit tengevolge van hypertensie het laagst is bij de hoogste inkomensgroepen. Dit gold alleen voor de blanke bevolkingsgroep. De mortaliteit was het hoogst bij niet-blanke mensen uit de laagste inkomensgroepen.

Het opmaken van de balans betreffende het belang van socio-economische aspecten in verband met de ontwikkeling en instandhouding van hypertensie is niet eenvoudig. Een aantal publicaties geven aan dat de prevalentie hoger is in de lagere klasse. Het is mogelijk dat de selectie van personen een belangrijke invloed heeft. In enkele Amerikaanse studies betreft het vaak 
immigranten. Ze zijn afkomstig uit een ander cultuurpatroon en vertonen mogelijk aanpassingsproblemen.

In een bevolkingsonderzoek ter opsporing van hoge bloeddruk werd door Eide (1982) bij 915 personen de levensomstandigheden geregistreerd, zoals werkspecten, slaapgewoonten, vrijetijdsbeleving en familie-omstandigheden. Mannen zonder eigen inkomen en mannen met een eigen zaak hadden een hogere bloeddruk dan mannen met een vast maandelijks inkomen. Slechte bereikbaarheid en/of langere afstand huis-werkplaats geeft ook een hogere bloeddruk te zien. Door Eide werden tevens verschillen in bloeddruk aangetroffen tussen gehuwden en niet-gehuwden. Ongetrouwde mannen hebben een hogere bloeddruk dan getrouwde mannen. Bij vrouwen zijn het niet zozeer werkvariabelen maar variabelen uit de persoonlijke en relationele sfeer die van invloed zijn op het bloeddrukniveau: veel problemen met de partner en met de kinderen gaat gepaard met hogere bloeddruk.

\subsection{LEVENSGEBEURTENISSEN}

De 'alloude' gedachte dat er een verband zou bestaan tussen het meemaken van ingrijpende gebeurtenissen en gezondheidsklachten is pas recent onderwerp van wetenschappelijke studie. Zowel retrospectief als prospectief onderzoek dat de relaties tussen deze gebeurtenissen en het optreden van lichamelijke en geestelijke problemen tracht te specificeren, is op gang gekomen. Holmes en Rahe (1967) stellen dat een gebeurtenis als 'stresswol' kan worden opgevat, als het optreden ervan een belangrijke sociale (her)aanpassing betekent voor de betrokkene(n). Zij gaan ervan uit dat het accent ligt op de verandering in een bepaalde toestand en niet op de psychologische betekenis, emotie of sociale wenselijkheid van een gebeurtenis. In de Anglo-Saksische literatuur wordt met de term 'life events' verwezen naar een gebeurtenis die op de een of andere wijze van ingrijpende betekenis is voor iemands bestaan. Of de nadruk wordt gelegd op sociale aanpassing of op de emotionele betekenis, is meestal ter keuze van de onderzoeker. Enkele voorbeelden van "life events" zijn: in het huwelijk treden, overlijden van partner of geliefd familielid, geboorte van een kind. In een overzichtsartikel concluderen Holmes en Masuda (1974) dat de aanpassing aan veranderingen significant gerelateerd is aan het optreden van gezondheidsstoornissen en dat naarmate de te leveren inspanning groter is, de waarschijnlijkheid toeneemt dat de betrokkenen klachten zullen ontwikkelen. Hierbij moeten we echter aantekenen dat de gevonden correllaties weliswaar zeer significant, maar over het algemeen niet erg substantieel waren. Zelden werd een Pearson-correlatie gevonden hoger dan .20 .

Over het proces dat aan deze relatie ten grondslag ligt, bestaat nog weinig overeenstemming. Zo is er onder andere verschil van mening over de invloed van de omstandigheden waaronder gebeurtenissen plaatsvinden, over de rol 
van de perceptie van de betrokkenen, de beschikbare sociale steun en over de wijze waarop men zich tegen gevolgen van levensgebeurtenissen teweer weet te stellen. In hoofdstuk 3 gaan we daar verder op in. Voor een deel zijn deze controverses ook terug te voeren tot een aantal methodologische kritiekpunten die betrekking hebben op de techniek waarop de recent meegemaakte gebeurtenissen geregisteerd worden door de lijst van Holmes en Rahe (Paykel, 1983, Zimmerman 1983, Sarason e.a. 1983), Elders zijn wij hierop gedetailleerd ingegaan (Van de Willige, Schreurs, Tellegen, Zwart, 1985).

Het is aannemelijk dat aanpassing-vereisende gebeurtenissen een rol spelen in de etiologie van essentiële hypertensie. Uit verschillende studies is gebleken dat door het meemaken van noodsituaties en crisissituaties zoals een oorlog, een orkaan of overstroming, de bloeddruk gedurende langere tijd kan worden verhoogd (Ruskin e.a., 1948; Scotch en Geiger, 1963; Gutman en Benson, 1971).

Een verdere ondersteuning van dit gegeven treffen we aan bij Lal, Ahuja, Madhukar (1982). In dit onderzoek wordt een inventarisatielijst van Tennant en Andrews (1978) voorgelegd aan 54 hypertensieven en een groep normotensieven, gematched op leeftijd, sexe en economische status. De hypertensieven rapporteerden meer gebeurtenissen dan de normotensieven. De ervaren mate van ongemak die deze gebeurtenissen met zich meebrachten, verschilden eveneens significant. Dit werd met name vastgesteld voor hypertensieve mannen boven de 45 jaar.

Alle bovengenoemde resultaten geven echter geen uitsluitsel over een rechtstreeks causaal verband tussen levensgebeurtenissen en hypertensie bij de mens. Het is niet te verwachten dat iedere persoon die wordt blootgesteld aan belastende psychosociale gebeurtenissen een te hoge bloeddruk zal ontwikkelen. Het is dan ook noodzakelijk om andere factoren bij dit onderzoek te betrekken, zoals persoonlijkheidskenmerken en omstandigheden waarin deze gebeurtenissen plaatvinden. Het is mogelijk dat deze een bufferende of beschermende, dan wel een stimulerende rol kunnen spelen bij de ontwikkeling van essentiele hypertensie.

Een algemeen methodologisch probleem in de studie naar de invloed van levensgebeurtenissen op de bloeddruk betreft het feit dat deze nagenoeg altijd retrospectief is onderzocht. Een te hoge bloeddruk gaat meestal niet ter zelfde tijd gepaard met merkbare vervelende lichamelijke verschijnselen. Een gedragsanalyse, ofwel functionele analyse, waarbij getracht wordt omstandigheden en gebeurtenissen te koppelen aan somatische verschijnselen, is derhalve niet goed uit te voeren.

Onderzoek van de laatste jaren naar de relatie 'life events' en hypertensie wijst erop dat de kwestie inderdaad erg gecompliceerd is. 
Svensson en Theorell (1983) hebben een groot aantal 18-jarige mannen geinterviewd waarbij gevraagd werd naar meegemaakte gebeurtenissen in hun leven. $\mathrm{Zij}$ vinden geen verschil in gerapporteerde gebeurtenissen tussen hypertensieven, normotensieven en hypotensieven. Deze conclusie correspondeert met de onderzoeksresultaten van Wheatly e.a. (1975) die ook geen significant verschil aantreffen tussen het aantal gebeurtenissen (gemeten met de lijst van Paykel, 1971) en hypertensie.

Door Theorell (1982) wordt erop gewezen dat hypertensie-patienten die zich melden bij hun arts waarschijnlijk allerlei vervelende gebeurtenissen hebben meegemaakt die hen ertoe brengen om nu de arts te bezoeken. Indien deze personen in een onderzoekspopulatie worden opgenomen dan wordt uiteraard een bevestiging gevonden van de positieve relatie tussen gebeurtenissen en hypertensie. Worden de hypertensieven echter gerecutreerd tijdens een bevolkingsonderzoek, dan constateren Svensson e.a. (1983) en Theorell e.a.(1985) dat hypertensieven juist minder recent meegemaakte gebeurtenissen rapporteren.

Onderzoek naar de etiologische betekenis van levensgebeurtenissen is pas goed mogelijk in een prospectieve studie waarbij herhaaldelijk en verspreid over langere tijd bij dezelfde mensen de bloeddruk wordt gemeten.

\subsection{SOCIALE STEUN}

Het begrip sociale steun ('social support') komt men veelvuldig in de psychologische literatuur tegen. De definiëring van het begrip en de wijze waarop het geoperationaliseerd wordt wijken echter sterk van elkaar af. Zo wordt het gemeten door bijvoorbeeld te vragen naar de aanwezigheid van een vertrouwelijke relatie, of naar de kwaliteit van de relatie met de partner, of naar vriendschapsbanden, naar de omvang van het sociale netwerk en/of sociale contacten. Zelden wordt zowel naar het sociale netwerk gekeken als naar de ervaren sociale steun. De laatste jaren is er echter in toenemende mate sprake van een consensus betreffende de conceptualisering van sociale steun. Men onderscheidt (Schaefer e.a. 1981):

a. emotionele steun (vriendschap, begrip),

b. waarderingssteun (respect, bewondering, waardering),

c. aanwezigheidssteun of netwerksteun (deel uitmaken van een netwerk, aanwezigheid van anderen, zich opgenomen weten in een groep), en

d. instruments steun (financiële hulp, advisering).

Een definitie waarin deze vier soorten van steun duidelijk te herkennen zijn komt van Cobb (1976): bij sociale steun gaat het om informatie die iemand de overtuiging geeft dat men om hem geeft, dat men hem waardeert, dat hij deel uitmaakt van een netwerk van mensen die onderling contact onderhouden en elkaar helpen. Het wezen van sociale steun is de zekerheid waarmee men zich bemind en gewaardeerd weet en denkt op hulp en aanwezigheid van 
anderen te kunnen rekenen. Het gaat dus om een cognitief evaluatieproces.

Er zijn duidelijke aanwijzingen dat sociale steun en kenmerken van het sociale netwerk waarvan lemand deel uitmaakt, een rol spelen bij het ontstaan en het beloop van tal van somatische en psychische klachten (Winnubst e.a., 1982; Kobasa e.a., 1983). Het prospectieve onderzoek van Berkman en Syme (1979) wees uit dat het sterfte-risico mede afhangt van factoren als burgerlijke staat, de aanwezigheid van vertrouwenspersonen en een goede vriendenkring. De meningen lopen echter uiteen over de sterkte van het directe dan wel indirecte effect van 'social support' met betrekking tot het woorkomen van lichamelijke en psychische klachten. Een belangrijk aandachtsveld is geweest of support als een onafhankelijke variabele kan worden opgevat of als een voorwaardelijke. In dit laatste geval wordt de gezondheidstoestand van iemand die in belastende omstandigheden verkeert niet aangetast dankzij de bufferende ofwel beschermende werking van de ontvangen sociale steun (Ormel, 1980; Winnubst e.a., 1982).

Verder is het nog onvoldoende duidelijk via welk werkingsmechanisme sociale steun een rol speelt (Kleber,1986). Biedt het de persoon de kans om tijdelijk de ervaren spanning te reduceren? Of biedt het iemand die in problemen zit de kans om de situatie rustig te bekijken en opnieuw te evalueren waardoor eventueel het bedreigende karakter van de situatie verminderd wordt? Een gebeurtenis kan als minder schokkend worden geïnterpreteerd wanneer men zich gesteund voelt door andere mensen. De ervaren sociale steun kan de zelfwaardering verhogen waardoor de interpretatie van eigen vaardigheden om het probleem te hanteren kan veranderen. Men kan door de sociale steun weer het gevoel krijgen de situatie aan te kunnen. Uit onderzoek van Kobasa e.a. (1983) en van Eijk (1979) is duidelijk geworden dat het simpelweg stellen dat 'social support' een beschermende werking voor de gezondheid heeft, ongenuanceerd is. De aanwezigheid van sociale steun kan er weleens toe leiden dat men het probleemoplossend vermogen beperkt en dat men daarmee veranderingen van de situatie blokkeert. De ervaren sociale steun kan volgen op een ongewenst (inefficiënt) gedrag en, door het belonende karakter van de bemoedigende opmerkingen van de steun gevende omgeving, kan dit ongewenst gedrag vaker gaan optreden in gelijksoortige situaties.

Onderzoek van French en Caplan (1972) toont aan dat steun van collega's en vooral van superieuren de kans vergroot dat mensen beter met de 'job stress' kunnen omgaan in de zin dat lichamelijke klachten voorkómen kunnen worden. Kobasa e.a. (1983) geeft in een serie onderzoeken aan dat mensen duidelijk verschillen in de mate waarin ze gebruik maken van de beschikbare sociale steun en dat steun binnen een bepaald netwerk (bijvoorbeeld het gezin) niet per definitie beschermend werkt voor problemen binnen een ander netwerk (bijwoorbeeld het werk).

Mede dankzij deze onderzoeken is duidelijk geworden dat het begrip sociale 
steun een complex fenomeen omvat. Zo kan het van belang zijn om binnen het onderzoek onderscheid te maken tussen de personen of groepen die de steun verlenen, de aard van de problemen waarvoor men steun ontvangt en de wijze waarop deze steun wordt verleend.

In een onderzoek van Van Bastelaer en Van Beers (1982) wordt gebruik gemaakt van een korte lijst om de ervaren sociale steun te meten in de werksituatie. Zij tonen onder andere aan dat sociale steun mede van invloed is op de hoogte van de bloeddruk. Ook door Winnubst e.a. (1982) wordt deze relatie vermeld.

$\mathrm{Er}$ is geen onderzoek bekend waarbij de rol van sociale steun in de etiologie en de handhaving van hypertensie expliciet en goed geoperationaliseerd is onderzocht. De bovenbeschreven opvattingen over de mogelijke modererende werking van sociale steun tussen de relatie stress en hypertensie verdient verdere toetsing. We willen in ons eigen onderzoek een eerste aanzet hiertoe geven.

\subsection{REACTIVITEIT VAN DE BLOEDDRUK}

In studies van langere tijd geleden werd er op gewezen dat hypertensieven in vergelijking met normotensieven een sterkere bloeddrukreactie vertonen op verschillende taken waaronder de "cold pressor test', waarbij de hand of voet gedurende 1 of 2 minuten in ijswater wordt ondergedompeld (Harlan e.a., 1964, Thomas e.a., 1982), 'stressful interview' (Wolf e.a., 1955) en geheugentesten (Jost e.a., 1952). Dit zou op een endogene factor duiden, met andere woorden deze hyperreactiviteit zou wel eens kunnen voorspellen of mensen in een later stadium hypertensie ontwikkelen.

Betreffende de specificiteit van fysiologische responsen en met name de cardiovasculaire reacties hebben Lacey en Lacey (1974) de 'intake-rejection' hypothese geformuleerd. Zij stellen dat cardlovasculaire processen samengaan met en functioneel zijn voor informatieverwerking. Bloeddrukverhoging en hartslagversnelling zouden horen bij 'rejection': het selectief en cognitief buitensluiten van informatie, terwijl het tegendeel zich zou voordoen bij 'intake": het opnemen van informatie. Lacey stelt dat dit proces van belang kan zijn voor de etiologie van essentiële hypertensie. Hypertensieven zouden een individuele response-specificiteit vertonen, waarbij 'rejection' op de voorgrond zou staan. Dit wil zeggen dat zij over verschillende situaties heen, dezelfde responsen vertonen waarbij informatie uit de buitenwereld wordt geweerd.

In hoofdstuk 4 zullen we verder terugkomen op deze zeer interessante aspecten van informatieverwerking en de wijze van omgaan met bedreigende stimuli.

Momenteel staat deze hyperreactiviteit weer volop in de belangstelling. 
Diverse onderzoekers hebben het concept van hyperreactiviteit een belangrijke plaats toegekend in hun theoretische uitgangspunten betreffende de etiologie van hypertensie, zoals Obrist (1981), Steptoe en Ross (1981), Surwit, Williams, Shapiro (1982), Folkow (1982) en Von Eiff (1984). Volgens Engel en Bickford (1961) zijn binnen het geheel wan fysiologische reacties op bedreigende stimuli de bloeddrukreacties geprononceerder aanwezig bij hypertensieven. Ook Schachter (1957) is van mening dat hypertensieven met grotere bloeddrukveranderingen reageren op diverse situaties. Als voorbeeld gaf hij bepaalde situaties waarbij men gevoelens van woede en angst ervaarde. Een ondersteuning van deze bevinding geven eveneens Richter Heinrich e.a. (1969) waarbij ze opmerken dat er ook sterkere bloeddrukreacties vertoond worden op zogenaamde neutrale geluidsprikkels.

Baumann e.a. (1973) hebben er vervolgens op gewezen dat deze fasische bloeddrukveranderingen (tijdelijk van aard en gesuperponeerd op een bepaalde basiswaarde) van hypertensieven vaak 15 tot 20 minuten kunnen aanhouden in vergelijking met de 2 à 3 minuten bij normotensieven.

Onderzoek van meer recente datum toont echter aan dat de aard van de stressoren een grote rol speelt voor de grootte van de bloeddrukreacties. In verscheidene onderzoeken wordt aangetoond dat mensen met een licht verhoogde bloeddruk normale bloeddrukreacties vertonen op de 'cold pressor test" (Eliasson e.a., 1983) maar ook op statische en dynamische oefeningen (Sannerstedt e.a., 1972; Julius e.a., 1968). Wel worden er meer geprononceerde bloeddrukreacties geconstateerd wanneer het mentale taken betreft zoals rekensommen, het vermijden van schokken en de "color-word interference' test (Jern 1984).

Obrist (1976) heeft gesteld dat associatie van somato-motorische en cardiovasculaire veranderingen samenhangt met het appèl dat een situatie of een uit te voeren taak met zich meebrengt. Dit appè kan resulteren in een actieve dan well een passieve wijze van reageren. Een taak die om een actieve response vraagt is bijvoorbeeld, zo snel mogelijk reageren op een toon teneinde een electrisch schokje te vermijden. De taken die echter een passieve respons uitlokken zijn de 'cold-pressor-test', het kijken naar een schokkende film. Het zijn meestal taken die men moet 'ondergaan'. Bij een dergelijke passieve manier van omgaan met een aversieve situatie zouden de veranderingen in bloeddruk en hartfrequentie in gelijke mate opgaan met de voedings- en zuurstofbehoefte van het somatomotorische systeem. Bij een actieve wijze van omgaan met deze stimuli kan er een dissociatie optreden: de cardiovasculaire veranderingen zijn erop gericht om een motorische inspanning mogelijk te maken ( sterkere systolische bloeddruk en hogere hartfrequentie), maar aangezien deze niet altijd volgt, is er sprake van een zuurstofoverschot. Obrist (1976) wijst hierbij op mogelijke gevolgen voor het ontwikkelen van hypertensie. Eerdere bevindingen van Brod $(1959,1960)$ wijzen in dezelfde 
richting. Gedurende emotionele stress zoals bij een interview of gedurende zware lichamelijke inspanning wordt er bloed aan de ingewanden en de huid onttrokken en stroomt het vooral naar de skeletspieren. Dit treedt zowel bij hyper- als bij normotensieven op, maar bij eerstgenoemden vindt dit ook plaats tijdens periodes van rust. Volgens Brod (1960), Kaplan (1978) en Groen e.a. (1982) is het mogelijk dat er bij essentiële hypertensie sprake is van een verstoorde regulatie van deze haemodynamische reacties die nodig zijn om het organisme voor te bereiden op lichamelijke inspanning. Deze onderzoeken wijzen op een hyperreactiviteit van hypertensieven op bepaalde (vooral mentale) stressoren. Duidelijkheid op dit gebied is er echter nog allerminst. Het is mogelijk dat hyperreactiviteit een gevolg is van cardiovasculaire veranderingen die in de loop van de tijd hebben plaatsgevonden. Volgens Steptoe (1984) is de selectie van de patiëntenpopulatie van het betreffende onderzoek van groot belang. Indien de patiënten worden gerecruteerd uit het medische kanaal dan bestaat de mogelijkheid tot een scheve verdeling met betrekking tot het aantal lichamelijke en psychische klachten, met name neuroticisme en depressiviteit (Steptoe e.a., 1984; Haynes e.a., 1978). Tevens bestaat de mogelijkheid dat een verhoogde bloeddruk reeds enkele jaren aanwezig is en dat mogelijke afwijkingen aan nieren en vatenstelsel mede van invloed zijn op de reactiviteit van het cardiovasculaire stelsel. Dat het innemen van bloeddrukverlagende medicatie eveneens van invloed hierop kan zijn spreekt voor zich. Indien men wil aantonen dat geprononceerde bloeddrukreacties op diverse stressoren een voorspellende waarde hebben voor een blijwende hypertensie, dan zal men dit middels een longitudinaal onderzoek moeten aantonen. Een tweetal onderzoeken waarbij een dergelijke follow up van meerdere jaren is uitgevoerd toont aan dat hyperreactiviteit op een 'cold pressor test' geen extra risico is (Harlan e.a. 1964; Thomas e.a. 1982). Verder is er een longitudinaal onderzoek uitgevoerd naar de relatie tussen hyperreactiviteit op cognitieve taken en cardiovasculaire complicaties. Aan adolescenten met een licht verhoogde bloeddruk werden een aantal mentale taken voorgelegd. $\mathrm{Na}$ een aantal jaren bleek dat juist die groep een blijvende hypertensie ontwikkelde die ook sterkere bloeddrukreacties vertoonde op de taken (Falkner e.a.1981).

We kunnen concluderen dat er nog onvoldoende evidentie bestaat voor de veronderstelling dat hyperreactiviteit op stressoren in een laboratorium situatie, een groot risico betekent voor het ontwikkelen van een blijvende hypertensie en cardiovasculaire complicaties. De gedachte en bevindingen van de onderzoeksgroep van Obrist zullen in een longitudinaal onderzoek getoetst moeten worden. Een eerste aanzet hiertoe vinden we in het longitudinale onderzoek van Falkner e.a. (1981). 


\subsection{PERSOONLIJKHEIDSKENMERKEN, ATTITUDES, GEDRAGSSTIJLEN}

\subsubsection{ONDERDRUKTE AGRESSIE}

De rol van persoonlijkheids- en gedragskenmerken bij het ontstaan van psychosomatische klachten is reeds vele jaren onderwerp van discussie.

Aan het eind van de jaren dertig, toen er een sterke opleving van de psychosomatische geneeskunde te bespeuren viel, meldden psychoanalytici dat hypertensiepatiënten angstig zijn en hun gevoelens van woede onderdrukken (Alexander, 1939). Een onderzoeksgroep in Chicago onder leiding van Alexander verrichtte pionierswerk op dit gebied. Psychoanalitici stelden aan de hand van protocollen van hypertensiepatiënten een psychodynamisch persoonlijkheidsprofiel op. Men constateerde dat er veelal sprake was van een onderdrukking van gevoelens van woede en agressie en formuleerde de 'repressed-hostility' hypothese (Alexander, 1939). Deze hypothese stelt dat er enerzijds sprake is van agressieve impulsen en dat er anderzijds een sociale controle bestaat om deze impulsen te onderdrukken. Tijdens de socialisatie- periode in de kinderjaren worden aanvallen van woede en agressie vaak door streng autoritaire ouders de kop ingedrukt. Hierdoor onstaat angst, die interfereert met het optreden van volgende agressieve handelingen en uitingen van woede die gericht kunnen zijn op bepaalde personen. Deze angst leidt tot een vlucht in een passieve, afhankelijke houding, waardoor conflicten met de buitenwereld kunnen worden vermeden. De woedegevoelens worden echter niet helemaal uitgeschakeld maar slechts onderdrukt. Daardoor blijft het autonome zenuwstelsel in geactiveerde staat hetgeen op den duur kan leiden tot een chronisch verhoogde bloeddruk.

Deze theorie omtrent de psychodynamische structuur van de hypertensiepatieent heeft veel clinici maar ook vele onderzoekers geïnspireerd. Een verzameling van gevalsbeschrijvingen levert een kleurrijk beeld op. Ter illustratie een enkel voorbeeld:

Binger e.a. (1945) omschrijven hypertensiepatiënten als volgt:

$\mathrm{Zij}$ hebben een onvermogen gemeenschappelijk om agressieve impulsen vrij uit te drukken. Ze hebben verder een opmerkelijke graad van zelfbeheersing. Oppervlakkig bezien geven ze de indruk van goed aangepaste en rijpe persoonlijkheden. Ze zijn bijzonder meegaand en proberen het de omgeving naar de zin te maken. Alhoewel ze bewust ambitieus zijn, beperken ze hun competitie tot hun fantasiewereld. Ze zijn onderdanig ten opzichte van autoritaire figuren die ze tegelijkertijd haten. Hun normale zelfbewustzijn is geïnhibeerd wat leidt tot zelfbeschuldiging en het verlies van zelf fertrouwen. Hoe onderdaniger en meegaander deze mensen zich tonen, hoe groter hun reaktieve vijandigheid wordt ten opzichte van degenen die de aanleiding voor hun onderdanigheid vormen. Er is een geprononceerd conflict tussen passief- 
afhankelijke en agressieve impulsen. Hypertensieven vertonen een sexuele inhibitie; 'verboden' rellaties veroorzaken angst en schuldgevoelens omdat deze in conflict zijn met hun geïnternaliseerde autoriteit. Zelfs het vechten tegen hun eigen onderdanigheid roept angst op en dringt ze terug naar de passief afhankelijke houding. Een vicieuze cirkel ontstaat, omdat de passieve afhankelijkheid minderwaardigheidsgevoelens bij hen oproept alsmede gevoelens van vijandigheid. Er ontstaat een emotionele verlamming door tegenstrijdige tendenzen van onderdanigheid en agressie.

Vele van deze patiënten hebben een arbeidsverleden dat gekenmerkt wordt door slecht betaalde en inspannende werzaamheden die ze jarenlang hebben aangehouden doordat hun competitie en zelfbewuste houding geinhibeerd is. Liever verrichten ze onprettige karweitjes, dan dat ze dat aan een ondergeschikte vragen, uit angst voor een negatief antwoord dat bij hun woede zou kunnnen oproepen die ze dan weer niet zouden kunnen uitdrukken. Omdat ze geen gebruik durven maken van de sociaal toegestane uitlaatkleppen van hun agressie verkeren ze in een chronische toestand van onderdrukte woede.

Ten aanzien van de wetenschappelijkheid van bovengeschetste beschrijving kan een vraagteken gezet worden. De beschrijving is uiterst subjectief en moeilijk repliceerbaar. In enkele gevallen is er weliswaar sprake van nauwkeurige observaties maar er ontbreken veelal geschikte controlegroepen. Zo kan men zich afvragen of de onderzochte groepen wel representatief zijn voor de populatie van hypertensieven als geheel. Immers, juist mensen met een meer dan gemiddelde mate van hulpvaardigheid, offerbereidheid, en neiging tot onderwerping zouden meer dan anderen bereid kunnen zijn zich voor langere tijd beschikbaar te stellen voor onderzoek en zich te melden voor therapie. Met andere woorden misschien is er sprake van een selectie-bias waardoor ten onrechte bovengenoemde eigenschappen worden toegedicht aan alle mensen met hypertensie.

Behalve rapportages van clinici bevestigden ook onderzoekers met eenzelfde psycho-analytische achtergrond nog lange tijd het bovengeschetste beeld van de hypertensiepatiënt die gebukt gaat onder een intrapsychisch conflict. Zij maakten hierbij gebruik van projectieve technieken zoals de Rorschach test, de 'Rozenzweig Picture Frustration test' en de 'Draw-a-person-test" (Van de Loo, 1952).

Een algemeen kenmerk van projectieve technieken is dat zij de persoon ambigu en ongestructureerd stimulusmateriaal bieden, waarop deze zijn eigen structuur kan projecteren. Alhoewel deze projecties een rijke bron van informatie voor de onderzoeker zijn, levert een gebrek aan objectiviteit bij het scoren door een inadequate standaardisatie en twijfelachtige validiteit nogal wat problemen op. 
Uit de verrichte onderzoeken is er niet een die duidelijke uitspraken kan rechtvaardigen over een specifieke persoonlijkheidsstructuur van hypertensieven. In veel gevallen is gewerkt zonder juiste referentiegroepen en zijn er slechts summiere gegevens beschikbaar over de hypertensiegroep, zodat generalisatie niet altijd verantwoord is.

De 'repressed-hostility' hypothese is eveneens getoetst met meetinstrumenten die over het algemeen een hogere mate van betrouwbaarheid bezitten dan de projectietesten. Door Hokanson e.a. $(1961,1962,1963)$ werd de repressedhostility hypothese verder theoretisch uitgebreid en getoetst via een serie experimenten. Er wordt gesteld dat het blokkeren van agressieve gevoelens, frustrerend werkt en de vijandige gevoelens nemen daardoor eerder toe dan af (agressie-angst). Personen met een hoge agressie-angst zullen ook sterke gevoelens van woede ervaren. $\mathrm{Zij}$ voelen zich hierover erg schuldig met als gevolg dat het uiten van de agressieve gevoelens weer onderdrukt wordt.

In een serie laboratoriumexperimenten toonden Hokanson e.a. $(1961,1962$, 1963) aan dat personen die hoog scoorden op 'hostiliteit' nadat zij waren geconfronteerd met een experimentele frustratiebron, een sterke toename van systolische en diastolische bloeddruk vertoonden mits ze geloofden dat ze gestraft konden worden voor een onvoldoende prestatie. Angst belemmerde het uiten van woedegevoelens, hetgeen gepaard ging met bloeddrukstijging. De expressie van agressie ging echter eveneens gepaard met een stijging van de bloeddruk maar verdween weer vrij snel nadat de woede was geuit. Dit gebeurde echter alleen wanneer men ook tevreden was over de wijze waarop men de betreffende gevoelens van woede had geuit en niet wanneer men zich hierover schuldig voelde vanwege strijdige normen of rolopvattingen.

'Anger, hostility, and aggression have long been regarded as important factors in the etiology of essential hypertension', aldus Spielberger e.a. (1985). $\mathrm{Ze}$ wijzen er op dat de begrippen echter zeer verschillend worden geoperationaliseerd in de diverse onderzoeken waardoor het moeilijk wordt om de resultaten eenduidig te interpreteren. Gegeven de overlap tussen de begrippen spreken ze dan ook van het AHA-syndroom waarvan de woede het belangrijkste onderdeel is. Zij stellen de volgende definities voor:

'Anger refers to an emotional state that consists of feelings that vary in intensity, from mild irritation to rage. Hostility involves angry feelings and has the connotation of a complex set of attitudes that motivate aggressive behaviour directed toward destroying objects or injuring other people. Agression implies destructive behaviour directed towards other persons or objects' (Spielberger e.a., 1985, p 7).

Het verband tussen de bloeddruk en het al dan niet uiten van gevoelens van woede, werd in een uitgebreid onderzoeksprogramma van Harburg en zijn medewerkers nader bestudeerd. Er werd een vragenlijst geconstrueerd die een aantal hypothetische woede-uitlokkende situaties bevatte. Personen werden 
geclassificeerd als "anger-in". als ze aangaven geen gevoelens van woede te ervaren in de betreffende situaties of wel woedend waren maar dit niet lieten merken. Personen die wel gevoelens van woede ervaarden en deze ook uitten, werden ingedeeld als 'anger-out'. De vragenlijst bevatte tevens items waarbij werd nagegaan in hoeverre men zich over het uiten van deze gevoelens van woede schuldig voelde (guilt - no guilt). Harburg e.a. (1973) toonden aan dat in een 'high socioecological stress area' ( hoge bevolkingsdichtheid, veel criminaliteit, laag inkomen) personen die hun gevoelens van woede inhouden, een hogere diastolische bloeddruk hebben. Ongeveer één van de vijf "anger-in" respondenten werden gediagnosticeerd als hypertensief tegenover eén op de acht 'anger-out' respondenten. Vooral personen met een copingstijl omschreven als 'anger-in/guilt' (ofwel 'suppressed hostility'), hadden een hogere diastolische bloeddruk in wergelijking met de groep omschreven als 'anger-out/no guilt' ('expressed hostility":.... 'an individual's tendency to inhibit aggresive attitudes or actions and feel guilty if such behavior should be expressed'). Dit effect wordt sterker indien er ook nog andere risicofactoren aanwezig zijn; zo lopen niet-blanke mannen die hun gevoelens van woede niet uiten en in een 'hoog stress' gebied wonen de grootste kans op het ontwikkelen van hypertensie (Harburg e.a. 1979).

Van der Ploeg e.a. (1985) constateren dat hypertensieven die naar de polikliniek komen ter controle van hun reeds langere tijd bestaande hypertensie, significant meer boosheidsreacties rapporteren. Dit verschil werd alleen bij de mannelijke respondenten aangetrof fen. Ook Dimsdale e.a. (1986) constateren een hogere systolische bloeddruk bij repondenten die volgens de indeling van Harburg zouden behoren tot de groep 'anger-in'. Dit verband bleef aanwezig ook al werd er gecorrigeerd voor leeftijd, gewicht en sociale klasse, maar was alleen van toepassing voor de groep van blanke mannen. Het onderzoek van Gentry e.a. (1982) toont aan dat de relatie tussen gevoelens van woede (al dan niet geuit) en bloeddruk gecompliceerder is en dat er belangrijke tussenschakels dan wel interactie-effecten aanwezig zijn: personen die gewoonlijk hun woede uiten wanneer ze daartoe door anderen worden uitgedaagd, hebben over het algemeen een lagere systolische en diastolische druk in vergelijking met diegenen die hun woede niet uiten. De onderzoekers brengen echter een verdere detaillering aan door te wijzen op enkele mediërende factoren zoals werkbelasting of problemen in het gezin: personen met zowel een hoge werkbelasting (of gezinsproblemen) als een tendens om hun woede te onderdrukken ('anger-in') hebben de hoogste diastolische bloeddruk. Dit interactie-effect van werkbelasting treedt niet op bij personen die hun woede wel kunnen uiten.

Cottington e.a. (1985) wijzen eveneens op een belangrijke tussenschakel: vooral die personen die hun woede onderdrukken en die chronisch in een situatie verkeren waarbij deze woede telkens wordt opgeroepen, lopen het grootste risico om hypertensie te ontwikkelen. Dit zou volgens hun met name kunnen gebeuren in een chronische werkbelasting. 
Door Spielberger e.a. (1985) worden echter enkele kritische kanttekeningen geplaatst met betrekking tot de validiteit van de door Harburg geintroduceerde vragenlijst: zowel wat de begripsvaliditeit betreft als de generaliseerbaarheid van de gegevens naar andere bevolkingsgroepen dan stedelingen. Tevens zetten ze een wraagteken bij de twcedeling 'anger-in' en 'anger-out'. In de eerste categorie werden ook die personen geplaatst die ten aanzien van de beschreven situaties in de vragenlijst aangeven dat ze geen woede ervaren. Spielberger e.a. (1985) ontwikkelden een eendimensionele vragenlijst die het uiten van woede zou meten ( de Anger-Expression Scale). $\mathrm{Zij}$ yerwijzen in het artikel naar een intern rapport van Johnson waarin deze de lijst heeft voorgelegd aan 1114 studenten waarbij tevens twee keer de bloeddruk werd gemeten. Door Johnson werd geconstateerd dat voor mannen en vrouwen een positieve relatie bestaat tussen de mate waarin gevoelens van woede werden geïnhibeerd en de systolische en de diastolische bloeddruk.

Uit bovenstaande onderzoeken blijkt dat inhibitie van gevoelens van woede een stijging van de bloeddruk kan veroorzaken. Dit effect wordt sterker indien deze gevoelens in een bepaalde situatie vaak worden opgeroepen.

\subsubsection{NEUROTICISME EN ANGST}

\section{Neuroticisme}

Naast onderzoek omtrent de 'repressed-hostility hypothese' is het verband nagegaan tussen hoge bloeddruk en diverse psychologische kenmerken waaronder 'neuroticisme'. De definitie en de operationalisering van het begrip neuroticisme lopen echter zeer sterk uiteen maar in de meeste gevallen is gebruik gemaakt van neuroticisme score, gemeten met de Eysenck Personality Inventory (Eysenck,1964). Een verband tussen neuroticisme en de hoogte van de bloeddruk is herhaaldelijk aangetoond (Sainsbury 1964; Robinson, 1962, 1968; Cochrane, 1969; Drunkenmölle, 1976). Cochrane (1973) wijst er echter op dat ook mensen met andere psychosomatische klachten een hoge neuroticisme-score hebben, zodat het geen specifiek kenmerk van mensen met hoge bloeddruk thoeft te zijn. Robinson (1962) toonde aan dat hypertensieven die onder medische behandeling stonden een hogere score op de neuroticisme vragenlijst hadden dan hypertensieven die waren geselecteerd uit de algemene bevolking. Cochrane (1969) bevestigde dat hypertensieven die behandeld worden weliswaar neurotischer zijn dan andere patiënten, maar dat dit niet van toepassing is voor mensen waarbij recent de hypertensie is ondekt. We moeten dus ernstig rekening houden met somatopsychologische aspecten.

Robinson (1968) stelt:

..thus the observations could be explained in terms of selection by the general practioner, or by the patient himself in his decision to consult a doctor about a particular symptom, without the necessity of any causal relationship between neuroticism and hypertension' (pag. 63). 
Ook Davies (1970) heeft erop gewezen dat er psychologische verschillen aanwezig zijn tussen mensen die ervan op de hoogte zijn dat hun bloeddruk te hoog is en mensen die zich daar niet bewust van zijn. Hij pleitte er daarom voor om voortaan een onderscheid te maken tussen zogenaamde 'awarehypertensives' en 'non-awares'.

In een onderzoek bij een bedrijfsgeneeskundige dienst trof Davies (1970) zelfs een lagere score voor neuroticisme aan bij mannen van middelbare leeftijd bij wie recent een verhoogde bloeddruk werd geconstateerd. Dit gegeven werd eveneens gevonden door Cochrane (1973): personen van wie tijdens het bevolkingsonderzoek bleek dat de bloeddruk te hoog was scoorden lager op Eysenck's neuroticismelijst. Hij concludeerde dat de hogere neuroticisme scores ( $\mathrm{N}$-score) voor hypertensieven, geconstateerd in andere onderzoeken, wel eens het gevolg kunnen zijn van het feit dat deze personen ervan op de hoogte waren dat hun bloeddruk te hoog is en zich derhalve zorgen maken over mogelijke risico's voor de gezondheid.

Een lagere $\mathrm{N}$-score voor hypertensieven rapporteren ook Berglund e.a. (1975), Meyer e.a. (1977) en Santonastaso e.a. (1984).

\section{Angst}

Er zijn zeer vele studies verricht naar de relatie tussen angst en bloeddruk waarbij gebruik gemaakt werd van zeer uiteenlopende meetinstrumenten. We zullen slechts enkele onderzoeken bespreken.

Baer e.a.(1979) toonden in een cross-sectionele studie aan, dat hypertensieven hogere angstscores hebben dan normotensieven. Als angstmaat werd een vragenlijst gehanteerd die bij ons vrij onbekend is, de Baer Self Report Scale. Banahan e.a. (1979) gebruiken de State-Trait Anxiety Scale van Spielberger, een lijst die ook in de Nederlandse taal beschikbaar is (Van der Ploeg e. Et, 1980). Ze constateren dat personen met een hoge angstdispositie een hogere systolische bloeddruk hebben en dat personen met een hoger toestandsangst zowel een hogere systolische als diastolische bloeddruk hebben. Verschillen in angstscores tussen de als hypertensief gediagnosticeerde personen en normotensieven, bleken echter niet aantoonbaar.

In Nederland is een vragenlijst-onderzoek verricht naar de relatie angst en hypertensie door Van der Ploeg e.a. (1985). Zij treffen hogere toestandsangst en dispositie-angst ( zie voor omschrijving van de begrippen 6.1.5) aan bij hypertensieven. De steekproef bestond uit hypertensieven die reeds langer een verhoogde bloeddruk hadden en daarvoor behandeld werden.

Schalling e.a.(1984) hebben een onderzoek uitgevoerd bij jonge mensen die weliswaar een verhoogde bloeddruk hadden maar nog niet gelabeld waren als 'hypertensie-patient'. Zij bleken angstiger te zijn dan een gematchte controlegroep. De angstmaat werd echter uitgedrukt in een verhoogde activiteit van het autonome zenuwstelsel en een hogere spierspanning. Behalve 
dat ze angstiger zijn voelen ze zich ook onzekerder in interpersoonlijke relaties en zijn ze subassertiever. Het is onduidelijk of een hoge mate van angst ook een belangrijke rol speelt in de etiologie van hypertensie.

\subsubsection{SUBASSERTIVITEIT}

De onderzoeken betreffende de 'repressed-hostility' hypothese zoals onder andere uitgewerkt door Hokanson (1963) brengen Manuck (1984) op de gedachte dat hypertensieven subassertief zijn.

Linden (1984) wijst echter op de problemen rondom de definiëring van het begrip. In de loop van de tijd zijn er aan het begrip assertiviteit verschillende betekenissen toegekend. Onder het begrip assertiviteit vallen min of meer agressieve gedragingen maar ook vriendschappelijke, affectieve en andere niet met angst gepaard gaande gevoelens. Brutten en Shoemaker (1967) geven in een theoretisch model het veronderstelde verband tussen sociale angst (angst gekoppeld aan sociale situaties of gedragingen) en subassertiviteit. $\mathrm{Zij}$ wijzen erop dat dezelfde stimulus die het sociaal gedrag ontlokt aan de persoon, leidt tot angst en spanningsgevoel dat zo sterk is, dat het het te ontlokken overte sociale gedrag hindert of verhindert op te treden. Problematisch sociaal gedrag is dan verstoring door angst (stotteren) of vermijden van angst (b.v. weglopen, iets onredelijks niet weigeren).

Dit betekent dat sociale angst en subassertiviteit moeilijk te onderscheiden zijn omdat ze dezelfde stimulus hebben en mede vanwege het gegeven dat er sprake is van wederzijdse beïnvloeding.

Een omschrijwing van het begrip assertiviteit waarin we ons het best kunnen vinden en dat we ook in het onderzoek centraal willen stellen, wordt door Van Son (1978) gegeven. Assertiviteit kan volgens Van Son (1978) omschreven worden als 'het omgaan met anderen, niet gehinderd of verhinderd door angst om met die ander om te gaan en zodanig dat het op korte en lange termijn leidt tot overwegend positieve gewenste gevolgen, zonder dat anderen er onterecht door benadeeld worden' (Van Son, 1978 pag. 7).

Het moge duidelijk zijn dat assertiviteit een vaardigheid is die in belangrijke mate het sociale gedrag kan bepalen. Mensen met een geringe mate van assertiviteit uiten hun gevoelens niet, kunnen aan hun eigen wensen vaak niet tegemoetkomen. Een logisch gevolg hiervan kan zijn een gevoel van angst, frustratie en woede, begrippen die telkens bij de omschrijving van de hypertensieven weer terugkeren.

In verschillende studies is dit aspect van subassertiviteit in verband met hypertensie herhaaldelijk aangetoond. In het onderzoek van Saslow, Gressel, Sobe, Dubois, Schroeder (1950) waarbij gebruik werd gemaakt van de interview-methode, werd duidelijk dat hypertensieven in vergelijking met 
normotensieven veel minder assertief waren en tegelijkertijd een hogere mate van angst vertoonden. Ook het onderzoek van Kalis, Harris, Sokolov en Carpenter (1957), waarbij gebruik werd gemaakt van psychodrama, ondersteunt deze bevindingen.

Na bestudering van de onderzoeken van Harris e.a. (1953), Gressel (1949), Wolf en Wolff (1951), Pilowsky e.a. (1973), Katzenstein e.a. (1974), Keane e.a. (1982), Linden en Feuerstein (1983), komen Julius en Cottier (1983) tot de volgende omschrijving:

"the personality of patients with borderline and mild hypertension is characterized by submissiveness to other people's views, by a motivation for contact with other people by an attempt to control behavior so as to be socially acceptable and by difficulties in expressing hostile feelings" (pag. 277).

Al deze gegevens ondersteunen de gedachte dat hypertensieven over het algemeen subassertiever zouden zijn dan normotensieven. Het betreft echter veelal studies met 'hypertensie-patiënten' die bekend zijn met hun diagnose en die zich onder behandeling hebben gesteld. Al eerder hebben we verwezen naar een opmerking van Steptoe (1985) waarbij gesteld wordt dat een patiënten-groep zich onderscheidt van niet-patienten op grond van psychologische kenmerken en lichamelijke problemen. Het is dus mogelijk dat er sprake is van een selectie-bias en het blijft een vraag of subassertief gedrag ook een mogelijke oorzaak kan zijn van hypertensie.

\subsubsection{BEHEERSINGSORIËNTATIE}

In paragraaf 2.3 hebben we de relatie tussen levensgebeurtenissen en hypertensie besproken. Hierbij werd zijdelings opgemerkt dat de wijze waarop men gebeurtenissen waarneemt, van belang kan zijn voor de gedragsmatige en fysiologische reacties die kunnen plaatsvinden. Deze wijze van waarnemen en betekenis geven aan de situatie is mede het gevolg van vroegere leerervaringen, persoonlijkheidskenmerken maar ook van de huidige ofwel actuele leefomstandigheden van betrokkene. In dit verband gaan we nader in op het theoretisch concept beheersingsorientatie, beter bekend onder de Engelse term 'locus of control'. Het concept is ontwikkeld en beschreven door Rotter (1966) . Mensen verschillen, zegt Rotter (1966) in de mate waarin ze het idee hebben zelf invloed of controle uit te kunnen oefenen op hun omgeving. Zij die menen dat factoren zoals geluk, kans, lot, of machtige anderen daarvoor bepalend zijn, worden 'externen' genoemd. Zij leggen de plaats van de beheersing van de gebeurtenissen meer buiten zichzelf en het eigen gedrag. 'Internen' daarentegen zijn mensen die een causaal verband leggen tussen eigen gedrag en consequenties van dat gedrag.

Hoewel het concept 'locus of control' erg breed is en theoretisch niet geheel 
uittgewerkt (Cohen en Dekker, 1980) is er erg veel onderzoek mee gedaan. Enkele bevindingen vatten we hier kort samen: internen zijn succesvoller op school en in hun werk, proberen meer inhoud te geven aan hun leven en spannen zich meer in om problemen op te lossen dan externen (Lefcourt, 1976). Een externe locus of control hangt samen met een grotere mate van angst en met een slechter functioneren (Phares, 1976).

Een interne beheersings-oriëntatie is niet altijd een voorwaarde om beter met problemen om te kunnen gaan. Indien de problemen in feite niet direct oplosbaar zijn door actief te handelen dan is een passief ondergaan van de situatie een adequatere strategie. De aard van de situatie is dus van even groot belang als de verwachtingen van de persoon.

De relatie tussen meegemaakte gebeurtenissen en gezondheidsstoornissen en gevoelens van onwelbevinden is groter bij externen dan bij internen (Parkes, 1984). Het is mogelijk dat externen andere strategieën gebruiken om met. onplezierige gebeurtenissen om te gaan.

Het is dus alleszins de moeite waard om de rol van de beheersingsoriëntatie eens nader na te gaan bij hyper- en normotensieven.

Er zijn slechts twee studies bekend over het verband tussen "locus of control" en hypertensie: een onderzoek van Naditch (1974) en een van Wennerholm en Zarle (1976). De laatsten vonden geen verschil in de mate van externaliteit tussen een groep patiënten met essentiële hypertensie en een groep normotensieven. Naditch vond wel een verband tussen externaliteit en bloeddruk. Dit verband was echter niet rechtstreeks, in die zin dat externaliteit op zich een goede voorspeller was voor hypertensie. Alleen bij personen die extern scoorden en ontevreden waren over "hoe de wereld er voor hen op dat moment uitzag', vond Naditch een hoog percentage ( $42.6 \%$ ) hypertensieven. Dus bij de mensen die het meest ontevreden zijn en tegelijkertijd het idee hebben geen invloed op hun omgeving te kunnen uitoefenen (en mogelijk door deze combinatie het meest gefrustreerd raken), komen de meeste hypertensieven voor. Deze relatie deed zich alleen bij mannen voor. Externaliteit functioneert hier als een moderator variabele voor de relatie tussen ontevredenheid en hypertensie. Deze relatie werd echter alleen geconstateerd bij mannelijke respondenten.

Het onderzoeksresultaat van Naditch (1974) zou erop kunnen wijzen dat hypertensieven weliswaar controle nastreven over hun eigen situatie waarmee ze ontevreden zijn, maar dat ze geloven geen daadwerkelijke verandering te kunnen weegbrengen. Deze gedachte is eerder door Graham $(1962,1972)$ gelanceerd zonder dat hij daarvoor hard bewijs kon leveren. Hij veronderstelde dat hypertensieven constant het gevoel hebben in een psychologisch gevaarlijke omgeving te verkeren, ze staan permanent klaar om deze bedreigende situatie het hoofd te bieden. 
De laatste jaren is veel aandacht geschonken aan een ander gedragspatroon, het zogenaamde coronary-prone-behavior-pattern. Dit gedragspatroon wordt in verband gebracht met een verhoogd risico op een hartinfarct en staat bekend onder de naam type-A gedrag. Hoewel de begrippen 'locus of control' en type-A zeer verschillend zijn kunnen er toch enige paralellen getrokken worden. We zullen in de volgende paragraaf dit type-A gedrag en de relatie met hypertensie uitvoeriger aan de orde stellen.

\subsubsection{TYPE-A GEDRAGSPATROON}

Het gedragspatroon type-A wordt door Jenkins (1979) als volgt gedefinieerd:

'The type-A behavior pattern is considered to be an overt behavioral syndrome or style of living characterized by extremes of competitiveness, striving for achievement, restlessness, hyperalertness, explosiveness of speech, tenseness of facial muscles, and feeling of being under the pressure of the time and under the challenge of responsibility. Persons having this pattern are often so deeply committed to their vocation of profession that other aspects of their lives are relatively neglected. Not all aspects of this syndrome or pattern need to be present for a person to be classified as possessing it. The pattern is neither a personality trait nor a standard reaction to a challenging situation, but rather the reaction of a characterologically predisposed person to a situation that challenges him or her. Different kinds of situations evoke maximal reactions from different persons'.

Een uitgewerkte theorie van het type-A gedragspatroon, dat begint bij het sociale systeem en eindigt bij problemen met de gezondheid, is afkomstig van Price (1982). Zij gaat ervan uit dat type-A gedrag een sterk cultureel geaccepteerde wijze van omgaan met angsten is. De angsten die aan het type-A gedrag ten grondslag zouden liggen zijn:

a. angst, dat men niet de moeite waard is,

b. angst dat er snel een einde komt aan alles dat op dit moment goed gaat, en

c. angst, onvoldoende mogelijkheden te bezitten om zich te "handhaven".

Sinds het type-A gedragspatroon in verband is gebracht met coronaire hartziekten door Rosenman e.a. (1964) is men er in veel studies impliciet vanuit gegaan dat het type A ook wel geassocieerd zou zijn met hypertensie. De kans dat een hypertensiepatiënt een myocard-infarct zal krijgen, is namelijk $4 \mathrm{x}$ zo groot als bij normotensieven (Pooling Project, 1978).

Rosenman, Friedman, Strauss, Wurm, Jenkins en Messinger (1966) constateerden inderdaad hogere blloeddrukwaarden bij type-A mannen. Dit was echter alleen het geval bij mannen jonger dan 50 jaar. Shekelle, Schoenberger, Stamler (1976) evenals Jenkins (1979) vinden echter geen relatie tussen het type-A gedrag en de bloeddruk, noch bij mannen noch bij vrouwen. Het is mogelijk dat de verschillende en soms zelf strijdige resultaten verklaard 
kunnen worden door het verschil in meetmethoden. Rosenman e.a. (1966) maakten gebruik van het gestructureerde 'type-A interview' (Rosenman en Friedman, 1964) waarbij ook gekeken wordt naar de stijlkenmerken wan het gedrag, terwiji de andere onderzoekers een vragenlijst hanteren, de Jenkins Activity Survey (Jenkins, Rosenman, Friedman, 1967).

In geen van bovenvermelde studies is vooralsnog aangetoond dat type-A een groter risico zou lopen om hypertensie te ontwikkelen dan type-B.

\section{Type-A en bloeddrukreacties op stressoren.}

De literatuur betreffende cardiovasculaire reactiepatronen van type-A mensen is vrij omvangrijk en weinig gestructureerd. De aard van de verschillende experimentele taken (actief versus passief) die aan het type-A worden aangeboden blijkt van groot belang. De verschillen in bloeddrukreacties op de betreffende taken kan eveneens tot stand gebracht worden door de wijze waarop de proefpersonen de taken opvatten (appraisal) namelijk als een bedreiging of een uitdaging, al dan niet plezierig en/of oplosbaar.

Dembroski e.a. (1977) vonden bij type-A, in vergelijking met type-B, sterkere systolische bloeddrukresponsies tijdens het uitvoeren van een milde stressor zoals een binaire keuzetaak.

Manuck e.a. (1978) lieten proefpersonen moeilijke cognitieve problemen onder tijdsdruk oplossen. $\mathrm{Zij}$ vonden sterkere systolische bloeddrukresponsies bij mannen van het type-A terwijl hartfrekwentie en diastolische bloeddruk geen verschil aangaven.

Het verschil in activiteit van het cardiovasculaire systeem op stressoren tussen type-A en B mensen komt dus vooral tot uiting in de systolische bloeddrukreacties. Dit geldt in mindere mate voor de hartslagfrekwentie en niet voor de diastolische bloeddruk. Het verschil in systolische bloeddrukreacties trad meestal op bij confrontatie met zogenaamde activerende situaties ook al vragen die op zichzelf weinig inzet. De type-A mensen lijken dus gekenmerkt door de neiging om in elke situatie een maximale prestatie te willen leveren. De bevinding dat het actief omgaan met de stressvolle situatie een tijdelijke systolische bloeddrukverhoging veroorzaakt, sluit aan bij de theorie van Obrist $(1976,1979)$. Hij concludeert dat adrenergische invloeden eerder opgeroepen of in stand worden gehouden als men aktief probeert om te gaan met taken of gelooft dat te kunnen doen. In een experimentele opstelling waarbij een situatie wordt gecreêerd waarin de proefpersonen zelf hun werktempo en de moeilijkheidsgraad van de opdrachten mogen bepalen, vonden zij de volgende resultaten: type-A legt zichzelf een hoger werktempo op en kiest ook voor een hogere werklast. Zij gaan hiermee echter beter om dan een vergelijkbare groep van type-B mensen. Op binaire-keuze-tests reageert type-A sneller, is accurater en bereikt een hoger aantal goede antwoorden in vergelijking met type-B. $\mathrm{Zij}$ spannen zich daarvoor niet meer 
in dan type-B, zowel gemeten op een zelf in te vullen vragenlijst als gemeten aan de hand van het adrenalinegehalte.

Zoals gezegd is in geen enkel onderzoek aangetoond dat type-A gedragspatroon en hypertensie duidelijk aan elkaar gekoppeld is. Toch is het goed voorstelbaar dat dit gedragspatroon een belangrijke risicofactor kan vormen in combinatie met andere factoren zoals het verkeren in een chronische sociale problematiek. We willen daarom nog even stil staan bij de vraag of type-A mensen zich ook duidelijk onderscheiden in het omgaan met problematische en moeilijk oplosbare situaties.

In het onderzoek van Glass e.a. (1977) wordt, kort samengevat, aangetoond dat type-A mensen rigide en onaangepast gedrag vertonen wanneer ze geconfronteerd worden met niet-controleerbare taken. $\mathrm{Zij}$ wijzen erop dat type-A grote angst hebben om de controle te verliezen over hun situatie. Als men wordt gedwarsboomd, reageert men agressief en zal men zich extra inspannen om obstakels te overwinnen. Type-A is prestatiegerichter, ook wanneer de taak niet bijzonder uitdagend is. Ook zijn ze in staat om langer door te werken en hebben ze de neiging om vermoeidheid te verdringen.

Smith en Brehm (1981) stellen dat type-A mensen een attitude bezitten waarbij men problemen en moeilijkheden niet uit de weg gaat.

In het algemeen zou men het volgende kunnen stellen: Bij een frusterende taak tonen type-A meer tekenen van ongeduld en boosheid dan type-B. Type-A is geneigd zich bij een fysieke takk meer in te spannen dan type-B. Na afloop zeggen ze echter minder vaak dat zij vermoeid zijn dan type-B. Type-A is geneigd sneller te werken wanneer de taak saillant is en de uitkomst iets onvoorspelbaars heeft. Vanwege hun competitief karakter werkt type-A harder dan type-B, ook als daar geen aanleiding toe is.

Verschillende andere onderzoeken hebben aangetoond dat type-A mensen bij confrontatie met bedreigende situaties verschillende defensiemechanismen zoals ontkenning en repressie hanteren (Carver, Coleman en Glass, 1976; Matthews en Brunson, 1979; Weidner en Matthews, 1978). Dit verschil in reactiewijzen tussen type-A en type B kan pas geconstateerd worden, zeggen Pittner en Houston (1980), in een zogenaamde 'threat to-self-esteem condition'.

In het onderzoek van Vickers, Hervig, Rahe en Rosenman (1981) wordt de relatie tussen A/B typologie en coping met psychosociale problemen op systematische wijze bestudeerd. 'Coping' wordt gedefinieerd in termen van: 'undistorted perceptions, a rational evaluation of the situation and appropriate action planning' (Vickees e.a., 1981, pag. 384). 'Defense' wordt gedefinieërd als een vervorming van de perceptie, onlogische cognitieve processen en een rigide gedrag. Er blijkt geen significante correlatie te bestaan tussen type-A gedrag en de scores op de coping-en defensielijsten. 
Vingerhoets en Flohr (1984) treffen een duidelijke correlatie aan tussen type$\mathrm{A}$ en enkele factoren van de copinglijst 'ways of coping' (Folkman en Lazarus, 1980): Type-A scoort hoger op de factoren 'problem focused / help seeking", 'selfblame' en lager op de factor 'acceptance'.

We willen in ons eigen onderzoek nagaan in hoeverre er een verband is tussen type-A, persoonlijkeidskenmerken en coping-gedrag.

\subsubsection{SAMENVATTING}

Ondanks het vele onderzoek naar specifieke persoonlijkheidskenmerken van hypertensieven is er nog niet veel duidelijkheid gecreëerd. Een gedeeltelijke verklaring voor de veelal strijdige onderzoeksresultaten kan worden gezocht in het feit dat meestal gebruik wordt gemaakt van subjectieve 'rating scales'. Er wordt soms gebruik gemaakt van zelf ontwikkelde vragenlijsten. Het probleem ligt hierbij vooral in het ontbreken van psychometrische gegevens zodat er onvoldoende inzicht is in wat de lijst precies meet en hoe betrouwbaar deze is (Ostfeld en Eaker, 1985).

Tevens is generalisatie van resultaten vaak onmogelijk dan wel hachelijk omdat in de betreffende publicaties zeer summiere gegevens worden vermeld over de wijze waarop de experimentele groep van hypertensieven is samengesteld. Het ontbreken wan gegevens omtrent leeftijd, criteria voor diagnose hypertensie, duur wan de hypertensie en het feit of medicatie ter verlaging van de bloeddruk wordt voorgeschreven, kunnen als voorbeeld worden genoemd.

De meeste onderzoeken betreffende persoonlijkheidskenmerken en hypertensie, zijn correlationeel van aard waardoor oorzaak en gevolg niet altijd even duidelijk van elkaar te scheiden zijn. Longitudinale panelstudies kunnen een oplossing bieden. Hierbij wordt gebruik gemaakt van lineaire structuur-technieken zoals Lisrel om causale verbanden te achterhalen (zie Ormel, 1980; Marcelissen, 1987).

Psychollogische karakteristieken van hypertensieven kunnen zeer wel een oorzakelijke factor vormen maar het kan ook zijn dat zij de gevolgen zijn van de langdurige bloeddrukverhoging. Vooral bij personen die reeds lang een hypertensie hebben, kan er hypertrofie zijn opgetreden van de perifere arteriolen. Deze hypertrofie kan dan op zichzelf de hoge bloeddruk tot gevolg hebben danwel handhaven.

Persoonlijkheidskenmerken ofwel omgevingsfactoren zoals 'life events" kunnen dus wel aan de basis van het etiologisch proces staan, maar ze kunnen gewijzigd, veranderd of verdwenen zijn wanneer de bloeddruk zich uiteindelijk gestabiliseerd heeft op een te hoog niveau.

De kennis hypertensie te hebben (consequenties op korte en lange termijn voor 
de gezondheidstoestand) kan een grote psychologische invloed hebben op de persoon in kwestie (Cochrane, 1969, Berglund e,a,, 1975; Monk, 1980); Steptoe, 1985). De psychologische kenmerken die gemeten worden bij hypertensieven kunnen derhalve als mogelijke consequenties worden opgevat van de wetenschap omtrent de gestelde diagnose hypertensie. Ook de onderzoeken van Haynes e.a. (1978) en Baer e.a. (1979) bevestigen de hypothese dat iemands gedrag ofwel persoonlijkheid kan veranderen tengevolge het feit dat men weet hypertensie-patient te zijn.

Na vijfig jaar onderzoek kunnen we stellen dat nog steeds onvoldoende duidelijk is welke persoonlijkheidskenmerken in verband gebracht kunnen worden met hypertensie. Er zijn echter wel duidelijke aanwijzingen dat de manier van omgaan met aanpassing vereisende situaties van invloed kan zijn op het ontstaan van essentiële hypertensie. Binnen dit proces spelen persoonlijkeidskenmerken een belangrijke rol.

Wij onderschrijven de gedachte van Weiner (1979) dat een ingewikkeld samenspel van verschillende factoren op zowel sociaal, psychologisch, cultureel, als fysiologisch niveau aan de basis ligt van het ontstaan van essentiële hypertensie. Men kan spreken van een mozaïek dat als een puzzel in elkaar moet worden gelegd. 







\section{HOOFDSTUK 3}

\section{STRESS, COPING EN HYPERTENSIE}

Iedereen krijgt in zijn leven meermalen of soms zelfs voortdurend te maken met problemen en aanpassing vereisende gebeurtenissen. Deze confrontatie betekent voor velen een belasting hetgeen op den duur kan leiden tot het ontstaan van lichamelijke en/of psychische klachten.

De opvatting dat het hierbij alleen om zelden voorkomende situaties en zeer ingrijpende "life events" gaat is inmiddels verlaten. Ook chronische problemen die zich kunnen uiten in dagelijks terugkerende irritaties blijken van belang voor het ontstaan van klachten (Burks en Martin, 1985). Onder 'life events' verstaat men veranderingen in de dagelijkse gang van zaken, die op de een of andere manier van betekenis zijn voor iemands bestaan. Men doelt dan op gebeurtenissen als een huwelijk, verhuizing, ontslag, enz. Een gebeurtenis is van betekenis als hierdoor schade of verlies voor de betrokkene is veroorzaakt of als belangrijk geachte doelen en plannen bedreigd worden of wanneer het zelfbeeld van de betrokkene in gunstige of ongunstige zin wordt beinvloed.

Om de relatie tussen gebeurtenissen en gezondheidsklachten duidelijker te krijgen, hebben Dohrenwend en Dohrenwend (1974) diverse aspecten van een gebeurtenis in een aantal dimensies onderverdeeld. De volgende dimensies worden hierbij onderscheiden:

- de mate van aanpassing die vereist is

- de duur en frequentie van de gebeurtenis

- de mate van (on)wenselijkheid of wel (on)plezierigheid

- de mate van voorspelbaarheid

- de mate van controleerbaarheid

Het pionierswerk van Holmes en Rahe (1967) betreffende levensgebeurtenissen heeft aangetoond dat er sprake is van een significante correlatie tussen het aantal meegemaakte gebeurtenissen en het optreden van gezondheidsstoornissen. De onzekerheid over eigen mogelijkheden om controle uit te oefenen tijdens confrontatie met aanpassing vereisende gebeurtenissen bepaalt volgens Manuck (1984) voor een belangrijk deel de aard van cardiovasculaire reacties.

Binnen zijn experimentele opstelling is controle over de taken feitelijk niet mogelijk. Aan een groep proefpersonen wordt echter gesuggereerd dat controle wel degelijk mogelijk is. Bij een andere groep wordt deze suggestie achterwege gelaten. Tijdens het uitvoeren van de taak treedt er een duidelijk verschil op in bloeddrukreacties tussen beide groepen. De personen die in de overtuiging waren dat er een mogelijkheid was om controle uit te oefenen 
vertoonden een hogere systolische bloeddruk. Dit was echter alleen het geval bij een moeilijke taak en niet bij een makkelijk uitvoerbare taak.

De fysiologische reactiepatronen op taken en gebeurtenissen hangt dus in grote mate af van de wijze waarop ze geinterpreteerd worden: of een situatie bedreigend is, hangt in eerste instantie af van de interpretatie van de betrokkene en is niet zonder meer af te leiden uit de 'feitelijke' gegevens.

De interpretatie van en de reactie op moeilijke omstandigheden wordt door Lazarus (1966) als twee afzonderlijke processen beschreven, respectievelijk aangeduid met 'appraisal' en 'coping'.

"Appraisal" is het cognitieve proces op grond waarvan een situatie wordt geinterpreteerd en geëvalueerd. Een bepaalde situatie kan voor iemand irrelevant blijken maar kan ook leiden tot aanpassing doordat hij als stressvol wordt geïnterpreteerd in de zin van: schadelijk, bedreigend dan wel uitdagend. Deze interpretatie gaat gewoonlijk gepaard met allerlei fysiologische veranderingen. Situaties die door de meeste mensen als onschadelijk of triviaal worden gezien, kunnen voor andere zeer bedreigend zijn. Deze waarneming en beoordeling van psychosociale stimuli zijn essentiële componenten bij de verwerking van ingrijpende gebeurtenissen en problemen. Wat blijkt in dit verband nu bij hypertensieven?

Door Graham (1972) is er op gewezen zoals we reeds eerder meldden, dat hypertensieven constant het gevoel zouden hebben in een psychologisch gevaarlijke omgeving te verkeren en dat ze daarom permanent klaar moeten staan om de bedreigende situaties het hoofd te bieden. Het is niet duidelijk dat hypertensieven zich hiervan steeds bewust zijn.

Uit verschillende onderzoeken (Handkins en Munz, 1978, Sapira e.a., 1971) komt naar voren, dat mensen met essentiële hypertensie bepaalde situaties systematisch anders percipiëren dan mensen met een normale bloeddruk. Situaties die door personen met een normale bloeddruk als bedreigend werden aangemerkt (het ging hier om de perceptie van problematische interpersoonlijke relaties) werden door mensen met hoge bloeddruk niet als zodanig waargenomen en beoordeeld. Met andere woorden: het bedreigende karakter van de situatie werd door hen ontkend.

Sapira e.a. (1971) verrichtte een experiment, waarin films werden vertoond met betrekking tot verschillen in arts-patiënt relatie. Eén variant van de film toonde een ongeinteresseerde, kortaf sprekende arts. In een andere variant trad de arts de patiënt zeer vriendelijk tegemoet. Tijdens het interview dat na het vertonen van de film plaats vond, bleek dat hypertensieven geen melding maakten van de onprettige arts-patiënt relatie. De bloeddrukreacties die tegelijkertijd werden gemeten waren echter beduidend hoger dan bij de normotensieven die de onprettige relatie in de film wel onderkenden. Dit buitensluiten van informatie blijkt in dit geval dus een weinig effectieve 
manier om controle op de situatie uit te oefenen. Op fysiologisch niveau brengt dit zelfs een verhoogde activatie met zich mee, waarbij vooral het sympatische zenuwstelsel is betrokken.

Ook in het onderzoek van Linden en Feuerstein (1983) wordt aangetoond dat hypertensieven minder 'stress' rapporteren dan normotensieven in een rollenspelsituatie. Weiner, Singer en Reiser (1962) merkten dat hypertensieven zich in een potentieel bedreigend klinisch interview isoleerden door zich af te schermen en niet te involveren.

Deze bovengenoemde onderzoeken steunen de veronderstelling dat hypertensieven allerlei gebeurtenissen en levensomstandigheden anders percipiëren in vergelijking met normotensieven.

Behalve deze verschillen in waarneming en beoordeling van psychosociale stimuli zijn er ook aanwijzingen dat de wijze van ermee omgaan, eveneens kan afwijken.

Reeds geruime tijd geleden omschreven Wolff en Wolf (1951) psychosomatische klachten als "a disease as a way of life". Het is een ziekte, een uitdrukkingsvorm van iemands persoonlijke stijl van leven. Een manier om zich aan te passen aan bedreigende situaties. Tegenwoordig spreekt men van 'coping'.

In navolging van Lazarus (1966) kan men 'coping' opvatten als de inspanningen van een individu indien de aan hem/haar gestelde eisen relevant zijn voor het welzijn (gezondheid, sociaal functioneren en zelfvertrouwen) en wanneer deze eisen een beroep doen op het aanpassingsvermogen. Deze definitie benadrukt adaptieve inspanningen (gedragsmatig, cognitief en emotioneel) die niet routinematig zijn; het resultaat van de anpassing is onzeker en de grenzen van het aanpassingsvermogen wan het individu kunnen bereikt worden. Uit deze definitie blijkt eveneens dat het begrip buitengewoon breed is en niet verwijst naar een eenmalige of specifieke actie. Coping is dan ook geen statische aangelegenheid maar is een proces dat uit vele afzonderlijke gedragingen bestaat. Een proces dat continu verandert, afhankelijk van nieuwe informatie, feedback en resultaten van bepaalde handelingen. Het is een complex stelsel van gedachten en gedragingen, waarbij verschillende copingvormen afwisselend of gelijktijdig op elkaar inwerken.

Op grond van in de literatuur beschreven copinggedragingen zoals door bijvoorbeeld Lazarus (1980), Pearlin en Schooler (1978), Robbins en Tanck (1978), Westbrook (1979) en Plutchik e.a. (1979), kunnen we drie copingcategorieën, ofwel strategieën onderscheiden:

1. Gedrag dat direct gericht is op de problematische situatie. Dit copinggedrag heeft rechtstreeks betrekking op het veranderen van de bedreigende situatie (instrumentele coping).

2. Cognities en emoties die gericht zijn op de beinvloeding van de perceptie 
en evaluatie van een probleem of gebeurtenis (de appraisal). Ze hebben ten doel om het bedreigende karakter van een situatie te veranderen, zonder dat hierbij de situatie zelf feitelijk wordt gewijzigd. Oorspronkelijk werd vooral vanuit psycho-analytische benadering veel aandacht besteed aan defensiemechanismen. Ook vormen van selektief waarnemen en interpreteren vallen hieronder, die meer in de richting gaan van 'comforting cognitions'. Een voorbeeld hiervan is argumenten aanvoeren om jezelf gerust te stellen in een moeilijke situatie. We zullen dit intra-psychisch copinggedrag noemen, waartoe we ook defensiemechanismen willen rekenen. Soms zullen door ons de begrippen defensie en coping naast elkaar gebruikt worden. Indien het begrip defensiemechanisme gehanteerd wordt, dan refereren we meestal naar onderzoeksgegevens verkregen vanuit een psychodynamische achtergrond en wanneer gebruik is gemaakt van de Defensie Mechanisme Lijst van Gleser en Ihilevich $(1969$, zie verder par. 5.1.3.7.).

3. Coping-gedrag dat is gericht op het reduceren van de ervaren lichamelijke en psychische spanning. Hieronder verstaan we wat Lazarus (1980) omschrijft als "symptom directed palliative modes of coping'. Door bijwoorbeeld veel te roken of te drinken worden pogingen ondernomen om de ondervonden spanning te verminderen (palliatieve coping).

In de praktijk blijkt dat het moeilijk is onafhankelijke copinggedragingen te onderscheiden omdat er veelal sprake is van een proces dat zich afspeelt tussen de persoon en diens omgeving. De meeste gedragingen beïnvloeden elkaar doordat ze zowel betrekking kunnen hebben op de situatie, de perceptie of de spanning.

Welk coping-gedrag men hanteert is afhankelijk van de betekenis die men aan de situatie toekent, van ervaringen die men in het verleden heeft opgedaan en van bepaalde persoonlijkheidskenmerken.

Of een bepaalde strategie effectief (in de zin van het voorkomen van lichamelijke kllachten en ziekten) genoemd kan worden hangt per geval af van de context waarin het gebeuren plaatsvindt. Een strategie als 'ontkenning' is mogelijk effectief op korte termijn als er geen actieve patronen van verweer mogelijk zijn of wanneer ingrijpen in de situatie de macht en de vaardigheden van de persoon te boven gaat. Vermoedelijk worden dergelijke passieve defensiemechanismen inadequaat wanneer ze noodzakelijke veranderingen gaan blokkeren.

Er is een aantal gegevens voorhanden dat er op duidt dat mensen met hoge bloeddruk bedreigende situaties op een andere manier aanpakken dan mensen met een normale bloeddruk. Uit onderzoek van Zimmerman (1979) en Minsky (1978) kwam naar voren dat hypertensieven in uiteenlopende situaties meer gebruik maken van 'passieve' copingsstrategieën dan normotensieven.

Ook Minsky (1978) concludeert dat hypertensieven meer gebruik maken van de defensiemechanisme 'ontkenning' en 'repressie' zoals gemeten met de vragenlijst Defense Mechanism Inventory van Gleser en Ihilevich (1969). Het betrof echter voornamelijk oudere hypertensiven $(\bar{x}=63$ jaar $)$. 
Manuck e.a. (1984) vatten de resultaten van deze onderzoeken als volgt samen: 'a defensive style that may promote submissive, deferential and inhibited behaviour in hypertensives by permitting a more benign appraisal of situations typically calling for assertive responding' (pag. 151).

Tenslotte willen we in dit verband nog wijzen op het belangrijke onderzoek van Jenkins e.a. (1984). In dit predictieve onderzoek werd onder meer nagegaan welke persoonlijkheidskenmerken en welk coping-gedrag het ontwikkelen van hypertensie bij vliegverkeersleiders kunnen voorspellen. Middels een speciaal ontwikkelde vragenlijst werd nagegaan: de wijze waarop men met de werkbelasting omging, de mate van betrokkenheid bij het werk, het sociale netwerksysteem en de recent meegemaakte gebeurtenissen werden gemeten. De vliegverkeersleiders werden gedurende drie jaar gevolgd waarna ze werden ingedeeld in een drietal categorieën: a. normotensieven zowel in het begin als op het eind van de periode, b. hypertensieven zowel in het begin als op het eind en tenslotte c. een groep 'toekomstige' hypertensieven. Deze laatste groep werd gevormd door die respondenten die in het begin van de studie nog een normale bloeddruk hadden maar op het einde van de 3-jarige periode een hypertensie hadden ontwikkeld. De 'toekomstig' hypertensieven verschilden in vergelijking met de normotensieven niet in toestandsangst en niet in boosheidsdispositie. Wel vertoonden ze een lagere angstdispositie, een lagere depressie-score zowel in vergelijking met de normo- als met de hypertensieve groep. 'Toekomstige' hypertensieven rapporteren ook minder levensgebeurtenissen, minder 'burn out', dat wil zeggen een gevoel dat men vaardigheid en energie verliest in verband met de baan. Verder zeggen ze significant vaker dat ze zich niet veel opofferingen hoeven te getroosten vanwege hun carrière, tevreden te zijn met het werk en geen problemen op dat gebied te ervaren, ze ontkennen vaker dat eventuele spanningen interfereren met hun persoonlijk, dagelijks leven.

Het idee dat 'ontkenning' van belastende situaties en problemen een rol kan spelen in de etiologie van essentiële hypertensie heeft ook fysiologisehe aanknopingspunten. Miller (1980) en Miller en Dworkin (1977) opperden reeds de veronderstelling dat hypertensieven geleerd hebben in bedreigende omstandigheden hun bloeddruk te verhogen doordat de baroreceptorstimulatie gepaard gaat met een 'verdovend' effect ("by elevating blood pressure so as to produce the sedativelike effects that accompany'). Deze verhogingen van bloeddruk tijdens stressvolle gebeurtenissen kunnen bekrachtigend werken doordat de vervelende emotie onderdrukt wordt. Ook Lacey en Lacey (1974) wijzen op dit fenomeen bij hun bespreking van de 'intake-rejection-theorie': bloeddrukverhoging kan ertoe leiden dat informatie uit de buitenwereld tijdelijk wordt afgesloten. Op de lange termijn kan het herhaald optreden van deze bloeddrukverhogingen leilden tot een 'hemodynamische disregulatie", volgens Schwartz (1977, 1979), hetgeen het begin kan zijn van essentiële hypertensie. 


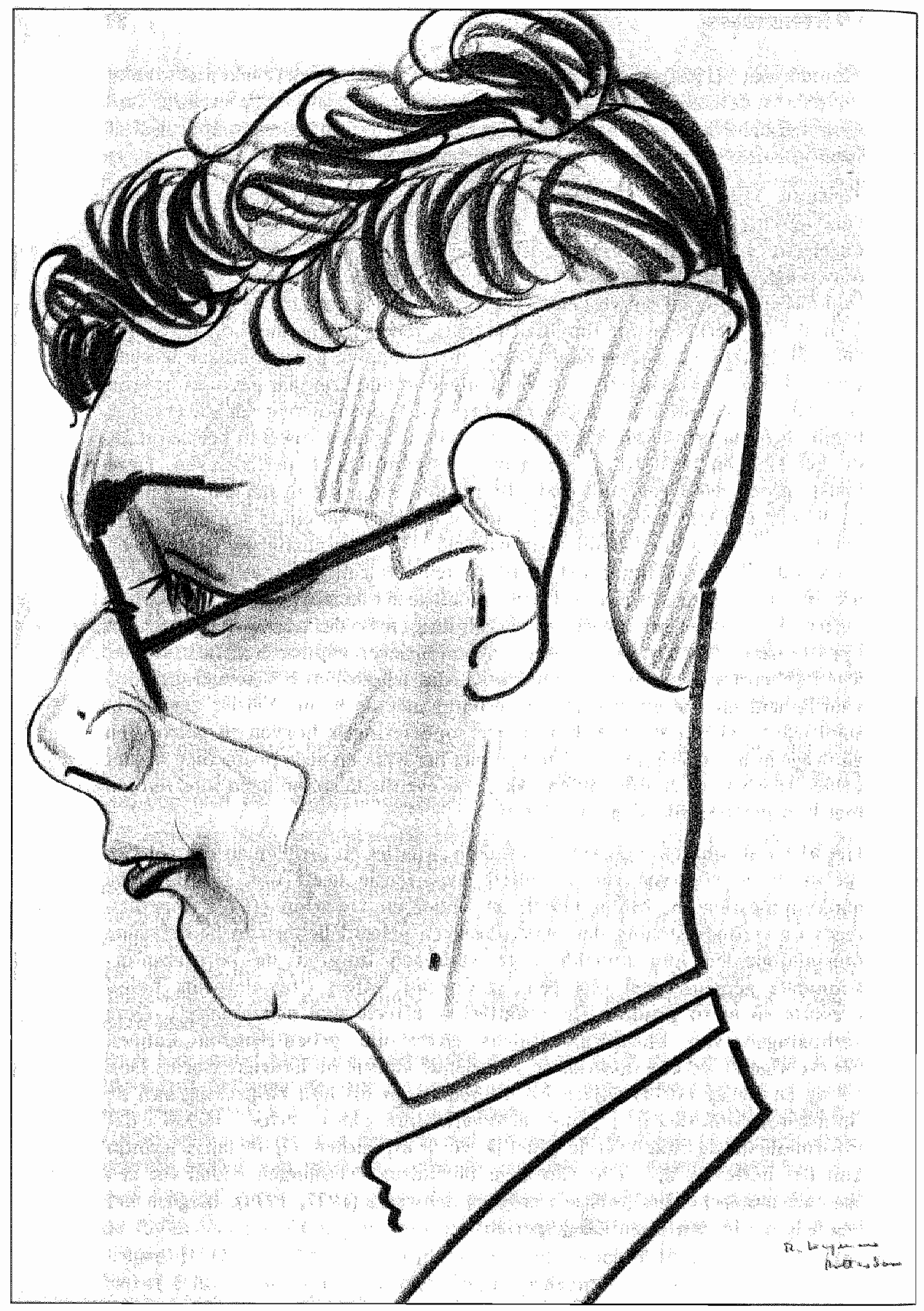




\section{HOOFDSTUK 4}

\section{THEORETISCHE UITGANGSPUNTEN EN VRAAGSTELLING VAN HET ONDERZOEK}

Zoals uit de vorige hoofdstukken moge blijken is het inzicht gerijpt dat het zoeken naar verbanden tussen psychosociale aspecten en hypertensie zich niet moet beperken tot enkelvoudige relaties. Men streeft ernaar om binnen het onderzoek duidelijkheid te krijgen of een cluster van persoonskenmerken en/of bepaalde gedragsstijlen in verband gebracht kunnen worden met de etiologie en het beloop van essentiële hypertensie. Daarnaast acht men het van belang dat verschillende andere risicofactoren gelijktijdig in het onderzoek worden betrokken (WHO, 1983; Shapiro e.a. 1979). Hierbij moet men vooral denken aan woon-, werkomstandigheden, het sociale netwerk en het support systeem, het meemaken van problemen en gebeurtenissen en wooral de eigen geschatte vaardigheid om met deze problemen om te gaan.

We onderschrijven de gedachte van Weiner (1979) dat een ingewikkeld samenspel van verschillende factoren op zowel sociaal, psychologisch, cultureel als fysiologisch niveau, aan de basis ligt van het ontstaan van essentiële hypertensie. Door het vele onderzoek dat de afgelopen 50 jaren is verricht is dit eveneens duidelijk geworden. Men spreekt in dit verband van een mozaïek dat als een puzzel in elkaar moet worden gelegd.

Als ordeningsprincipe voor het onderzoek naar de relatie tussen psychosociale factoren en essentiële hypertensie stellen we een onderzoeksmodel voor, waarin elementen uit diverse stress-modellen geïntegreerd zijn, zoals die van Lazarus (1980), Kagan en Levi (1974).

Het model staat afgebeeld in fig. 4.1

Dit multiconditionele model beschrijft het proces dat aanvangt met een psychosociale 'gebeurtenis (aanpassing vereisende gebeurtenis of problematische levensomstandigheid) en dat kan leiden tot essentiële hypertensie. De tussenliggende factoren hebben onder andere betrekking op de persoon die toegerust met bepaalde persoonlijkheids- en gedragskenmerken de belastende stimuli percipieert en ermee omgaat. Van stress kunnen we spreken wanneer de waargenomen eisen vanuit de omgeving de waargenomen eigen competentie om ermee om te gaan overschrijden. Een situatie kan als bedreigend of schadelijk worden ingeschat. Deze bedreiging heeft betrekking op de belemmering van belangrijk geachte doelen of plannen en op de persoonlijke integriteit wan de betrokkene, waaronder de aantasting van het zelfbeeld. Het ervaren van een gebeurtenis of omstandigheid als een bedreiging, gaat gepaard dat er een verhoogde fysiologische activiteit. Deze 


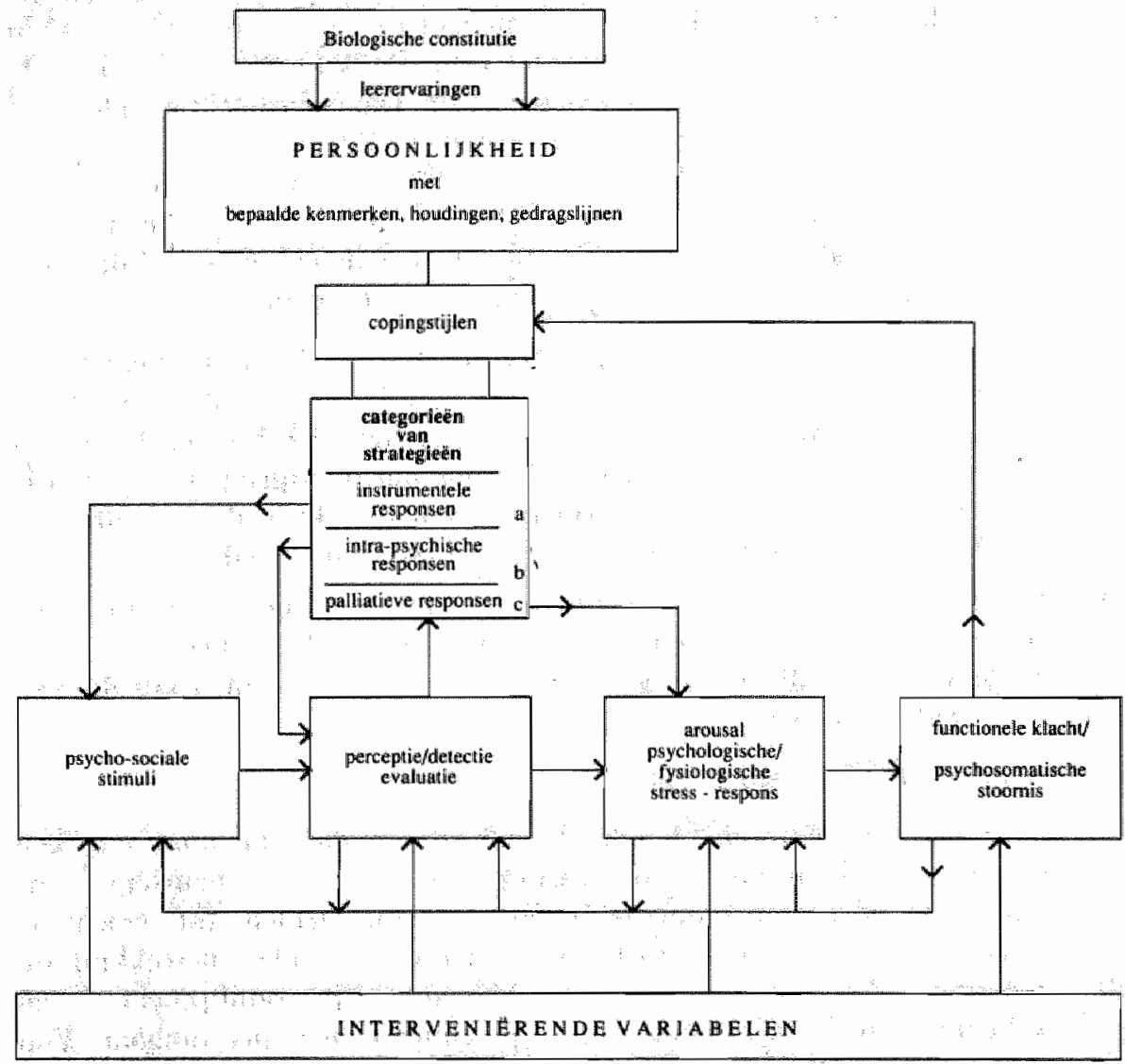


verhoogde activiteit van het centrale zenuwstelsel kan direct leiden tot merkbare lichamelijke klachten. Er kunnen veranderingen in de functie van de orgaansystemen optreden die eventueel leiden tot onomkeerbare veranderingen indien deze verhoogde fysiologische activiteit voortduurt of herhaaldelijk gedurende langere tijd plaatsvindt.

Een centraal concept binnen het onderzoeksmodel is 'coping': de manier waarop iemand zowel gedragsmatig, cognitief als emotioneel op aanpassing vereisende omstandigheden reageert, met het doel overmatige arousal te elimineren of te reduceren.

Hierbij zijn twee dimensies van belang: situationele variabelen en persoonlijkheids-variabelen. Onder situationele variabelen verstaan we de omgevingseigenschappen zoals die in de bedreigende situatie, het werk of het sociale netwerk zijn terug te vinden. Het gaat hierbij niet om objectieve eigenschappen van de omgeving maar om de subjectieve verwerking (zie hoofdstuk 5). Daarnaast zijn de dispositionele persoonlijkheidsvariabelen van belang zoals capaciteiten of vaardigheden, attituden, motivatie. $\mathrm{Zij}$ bepalen samen met de situationele variabelen de aard van het copingproces.

Het is de bedoeling om enkele onderdelen van het onderzoeksmodel nader te bekijken. Allereerst wordt nagegaan of bepaalde persoonlijkheidskenmerken en copingstrategieen hypertensieven van normotensieven kunnen onderscheiden. Plaatsen we de resultaten van de studies omtrent de 'hypertensie-persoonlijkheid' tegen de achtergrond van de huidige opvatting betreffende de begrippen stress en coping dan valt het volgende op: het lijkt erop dat er twee groepen hypertensieven zijn te onderscheiden op grond van persoonlijkheildskenmerken en de wijze waarop er met gebeurtenissen en problemen wordt omgegaan.

Een subgroep kenmerkt zich doordat ze op een 'compulsieve manier' controle op hun omgeving nastreven (Garamoni e.a. 1986). Het lijkt of ze gedreven worden door een rusteloosheid en angstig zijn dat ze de grip op de omgeving verliezen. $\mathrm{Zij}$ vertonen daarbij een actief coping gedrag. We willen hierbij ook wijzen op de visies van Glass e.a. (1977) en van Price (1982). De beschrijving stemt overigens ook overeen met het denkbeeld van Graham (1962). In zijn 'specificity of attitude' hypothese stelt hij dat .... "the hypertensive person feels threatened with being harmed by an ever-present danger: as a result, he or she feels the need to be on guard, and prepared to meet all threats' (Graham,1962, pag.702). Het beeld sluit ook goed aan op Alexanders' 'repressed hostility' hypothese.

De andere subgroep bestaat uit hypertensieven die vaak het defensiemechanisme 'denial' (ontkennen) hanteren. Zij kenmerken zich door een selectieve waarneming van gebeurtenissen en problemen. Op deze wijze proberen zij een confrontatie met de bedreigende aspecten ervan te 
voorkomen. $\mathrm{Ze}$ reageren dus met passieve copingsstrategieën waarbij ontkenning en vermijding centraal staan.

Het onderzoek van Baer e.a. (1979) ondersteunt de hypothese dat er twee groepen hypertensieven te onderscheiden zijn. Zij suggereren dat er mogelijk sprake is van een curvilineair verband tussen persoonlijkheidskenmerken en hypertensie. Op de 16 PF Cattell konden Baer e.a. (1979) twee groepen hypertensieven onderscheiden aan de hand van verschillende profielscores. Hypertensieven en normotensieven verschillen voornamelijk met betrekking tot twee affecten namelijk hostiliteit en angst, concluderen Baer e.a. (1979). De vergelijking met de groep 'compulsieve controleerders' en de 'ontkenners' dringt zich op.

Een centrale vraagstelling van het onderzoek is of er binnen de groep hypertensieven een dergelijk onderscheid tussen 'compulsieve controleerders' en 'ontkenners' gemaakt kan worden:

In onderstaande tabel worden de psychologische kenmerken genoemd die deze beide groepen zou kunnen onderscheiden.

Tabel 4.1. Hypothetisch onderscheid in twee subgroepen var hypertensieven op grond wan psychologiche kenmerken

\begin{tabular}{ll}
\hline "compulsieve controle" & "ontkenners" \\
\hline agressief & niet agressief \\
type-A gedrag & - \\
hoge boosheidsdispositie & lage boosheidsdispositie \\
hoog angstig & laag angstig \\
actief copinggedrag & passief copinggedrag, zoals ontkennen, afwachten en vermijden \\
\hline
\end{tabular}

Het is mogelijk dat het 'compulsieve' gedragspatroon veelal in de beginfase van essentiële hypertensie optreedt. Indien iemand deze kenmerken bezit en tevens in een situatie verkeert waarbij dit gedragspatroon regelmatig wordt uitgedaagd, dan zou dit een vergroot risico voor hypertensie kunnen betekenen (zie ook Price, 1982). Het gedragspatroon kan een weinig effectieve manier zijn om met bedreigende situaties om te gaan en problemen op te lossen. Dit kan met name het geval zijn, wanneer de problemen zich niet goed lenen voor een actief copinggedrag om tot een oplossing te komen. Het bedreigende karakter van de situatie blijft derhalve voortduren. Het veroorzaakt een verhoogde activiteit van het centrale zenuwstelsel en dus een tijdelijk verhoogde bloeddruk. Op den duur kunnen chronische veranderingen van het hart- en vatenstelsel een blijvend hoge bloeddruk veroorzaken via verhoging van de perifere weerstand. Het is mogelijk dat na verloop van tijd de moeilijke levensomstandigheden van destijds inmiddels opgelost zijn. Het kan echter ook zijn dat men meer berust in zijn lot en het bestaan van 
moeilijke problemen en situaties ontkent. In dit geval verwijzen we (zie hoofdstuk 3) naar de onderzoeksresultaten van Minsky (1978), Zimmerman (1979), Handkins en Munz (1978) en Jenkins (1984).

Deze vraagstelling betreffende subgroepen van hypertensieven wordt in een tweetal cross-sectionele studies verder geexploreerd. Hiervoor is het noodzakelijk yeel aandacht te besteden aan de psychologische meetinstrumenten die geacht mogen worden de meest relevante persoonlijkheidskenmerken te kunnen registreren. Enkele instrumenten bleken in het Nederlands taalgebied niet voorhanden te zijn zodat deze vertaald c.q. gewijzigd moesten worden zoals de lijst recent meegemaakte gebeurtenissen', de 'defensie-mechanisme lijst', 'extraversie' en 'neuroticisme" en een lijst om het coping-gedrag te meten.

Het eerste onderzoek is uitgevoerd bij de Bedrijfsgeneeskundige Dienst 'Utrecht'. Hieraan hebben ongeveer 50 mannelijke hypertensieven en 50 normotensieven deelgenomen. De volgende psychologische variabelen werden gemeten: beheersingsoriëntatie, assertiviteit, angst, neuroticisme, extraversie, type A-gedrag, defensiemechanismen. Tevens wordt nagegaan hoeveel recent meegemaakte gebeurtenissen men heeft meegemaakt.

In dit onderzoek zijn we in eerste instantie geïnteresseerd in de vraag welke persoonlijkheidskenmerken, hypertensieven en normotensieven onderscheiden. Tevens wordt reeds een aanzet gegeven om het bestaan van subgroepen binnen hypertensieven te exploreren.

Het tweede onderzoek is uitgevoerd bij de Nederlandse Spoorwegen. Eenzelfde soort vraagstelling werd onderzocht maar er vonden enkele wijzigingen en uitbreidingen plaats. Ook de onderzoeksgroep is aanzienlijk groter. Hierdoor is het mogelijk om binnen de groep personen met een verhoogde bloeddruk een onderverdeling te maken met betrekking tot het al dan niet bekend zijn met de diagnose hypertensie, de duur van de hypertensie en het gebruik van hypotensieve medicatie. Het is tevens mogelijk een groep respondenten te onderscheiden bij wie voor het eerst een verhoogde bloeddruk wordt ontdekt. Op deze wijze kunnen we bekijken of de bekendheid met de diagnose hypertensie belangrijke psychologische implicaties met zich meebrengen.

De tweede uitbreiding van het onderzoek bestaat hierin, dat het meetinstrumentarium is aangepast en uitgebreid. Met name is in samenwerking met Van de Willige aandacht geschonken aan de vaststelling van de levensomstandigheden (wonen, werken, sociale steun). De lijst recent meegemaakte gebeurtenissen is verder aangepast. Eveneens hebben we aandacht geschonken aan de ontwikkeling van een meetinstrument om het copinggedrag te scoren, de Utrechtse Coping Lijst. 


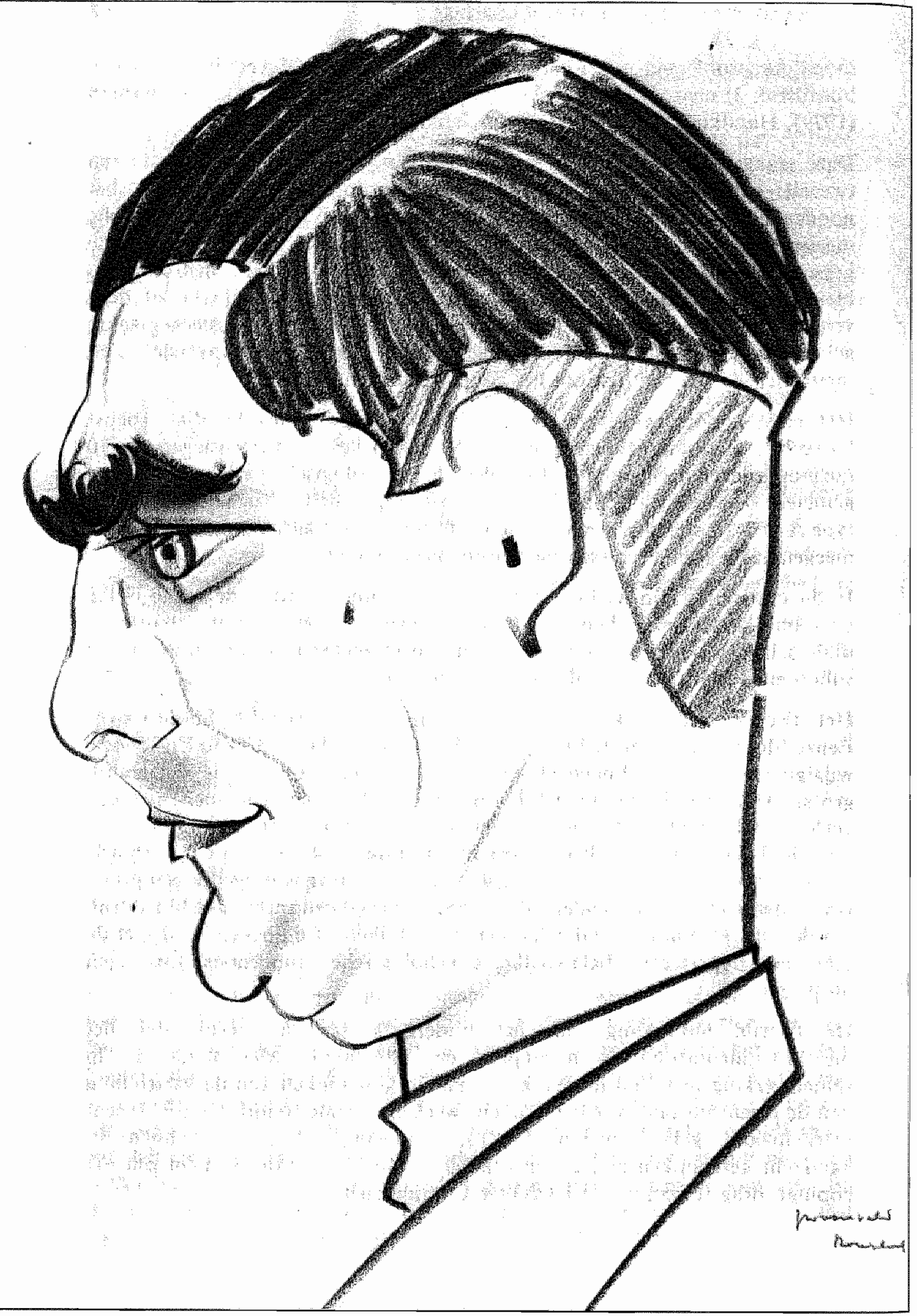




\title{
EMPIRISCH GEDEELTE
}

\section{HOOFDSTUK 5}

\author{
PERSOONLIJKHEIDSKENMERKEN EN \\ ESSENTIËLE HYPERTENSIE \\ Het BGD-onderzoek
}

\subsection{METHODE}

Het hier te beschrijven onderzoek werd verricht bij de Stichting Bedrijfsgezondheidsdienst "Utrecht'. Bij deze dienst hebben zeer uiteenlopende bedrijfstakken de verplichte periodieke medische keuring van hun personeelsleden ondergebracht. Via een brief van de directeur van de Stichting werd ad random aan een aantal recent gekeurde personen de vraag voorgelegd of ze medewerking wilden verlenen aan een onderzoek van de Rijksuniverstiteit Utrecht. Er werd op gewezen dat de gegevens anoniem verwerkt zouden worden. Door middel van het terugsturen van een antwoordstrook kon men kenbaar maken te willen deelnemen aan het onderzoek.

Vervolgens kregen de respondenten verschillende vragenlijsten (zie 5.1.2) thuisgestuurd met het doel deze in te vullen onder vermelding van een codenummer.

Van alle respondenten werden de volgende gegevens verkregen: leeftijd, geslacht, sociaal economische positie (volgens een classificatieschema ontworpen door het Instituut Toegepaste Sociologie te Nijmegen), gewicht, lengte, bloeddrukwaarden van alle eerdere keuringsdata, chollesterolgehalte, medicijngebruik en verschillende psychologisch variabelen.

\subsubsection{HYPOTHESEN}

In hoofdstuk 4 is ingegaan op de theoretische uitgangspunten van het onderzoek. De centrale vraagstelling is: zijn er psychologische verschillen tussen hypertensieven en normotensieven en zijn deze verschillen herkenbaar in een crosssectionele studie? Exploratief willen we nagaan of er twee psychologisch onderscheidbare groepen hypertensieven zijn. Hieronder staan de volgende hypothesen die getoetst zullen worden.

1. Getoetst wordt of hypertensieven meer recent meegemaakte gebeurtenissen rapporteren dan normotensieven en/of deze meer aanpassing met zich meebrengen.

2. Getoetst wordt of er een significant verschil in gemiddelde scores is tussen hypertensieven en normotensieven met betrekking tot de volgende persoonlijkheidskenmerken: angst gemeten met de TMAS, neuroticisme en 
extraversie gemeten met de EPI, type A gedrag met de JAS, assertiviteit en socialle angst met de LLSS, interne beheersingsoriëntatile met de Rotter I-E, defensiemechanismen met de DMI.

(De beschrijvingen van de verschillende meetinstrumenten staan vermeld in par.5.1.3.)

Verder willen we exploratief nagaan of hypertensieven zich onderscheiden in 2 subgroepen, die ieder op zich verschillen in persoonlijkheidskenmerken van normotensieven. Een groep van hypertensieven kenmerkt zich door een "compulsief" gedragspatroon. Dit gedragspatroon wordt geoperationaliseerd door type-A gedrag, hoog angstig, hoge boosheidsdispositie en een actief copinggedrag. Deze subgroep zal voorall zijn aan te treffen bij die hypertensieven bij wie de bloeddruk recent verhoogd is.

De andere subgroep van hypertensieven zal in vergelijking met normotensieven vaker positiever of neutraler reageren op situaties waarvan men in het algemeen kan verwachten dat ze belastend of negatief zijn. $\mathrm{Ze}$ maken meer gebruik van defensiemechanismen zoals 'ontkenning" en 'rationalisering'. Ze zullen minder gebeurtenissen rapporteren, zijn minder angstig en agressief en hebben een lagere boosheidsdispositie.

Deze groep zal vooral zijn aan te treffen bij die hypertensieven bij wie de bloeddruk reeds geruime tijd verhoogd is.

\subsubsection{BESCHRIJVING VAN DE STEEKPROEF}

In totaal werden 120 personen verzocht om medewerking te verlenen. Allereerst werden in willekeurige volgorde 60 personen geselecteerd uit een populatie van personeelsleden, die in het jaar voorafgaande aan ons onderzoek door de BGD waren gekeurd en waarbij de diagnose essentiële hypertensie was gesteld. Tevens werden 60 personen gekozen waarbij geen hypertensie was vastgesteld.

Voor de samenstelling van de groep personen met essentiële hypertensie werden de volgende criteria gehanteerd:

- een systolische bloeddruk hoger dan of gelijk aan $160 \mathrm{~mm} \mathrm{Hg}$

- en/of een diastolische bloeddruk hoger dan of gelijk aan $100 \mathrm{~mm} \mathrm{Hg}$

- deze waarden moesten in het jaar voorafgaande aan ons onderzoek minimaal 2 keer zijn gemeten door huisarts, bedrijfsarts of specialist

- of, het voorgeschreven krijgen van bloeddrukverlagende medicatie vanwege een door de arts vastgestelde hypertensie.

De referentiegroep bestond uit personen met een normale bloeddruk bij wie nooit eerder een verhoogde bloeddruk en ook geen andere cardiovasculaire klachten waren geconstateerd.

Tevens werden bij de selectie van alle personen de volgende criteria gehanteerd: 
- leeftijd tussen 30 en 65 jaar en van het mannelijk geslacht,

- niet gehandicapt,

- Nederlandse nationaliteit,

- laatste jaar medisch (goed) gekeurd,

- geen secundaire hypertensie,

- geen hartafwijkingen,

- geen nierstoornissen.

Van de 120 aangeschreven personen hebben 46 hypertensieven en 49 normotensieven aan het onderzoek meegewerkt. De redenen van weigering zijn niet te achterhalen. Wel is vastgesteld dat de 'non-responders' binnen de beide groepen niet verschilden van de 'responders" met betrekking tot sociaaleconomische klasse, gewicht, lengte en bloeddruk.

In onderstaande tabel staan enkele gegevens vermeld van de groep hypertensieven en van de groep normotensieven, $\mathrm{Er}$ zijn significante verschillen $(p<0.5)$ te constateren met betrekking tot leeftijd $(t$-waarde $=$ $4.22, \mathrm{p}=.01$ ) en quetelet-index ( $\mathrm{t}$-waarde $=-4.11, \mathrm{p}=.01$ ) en titeraard met de systolische en diastolische bloeddruk.

Tabel 5.1. Overzicht van gemiddelden en standaard deviaties van enkele gegevens met betrekking tot de groep hypertensieven en de groep normotensieven

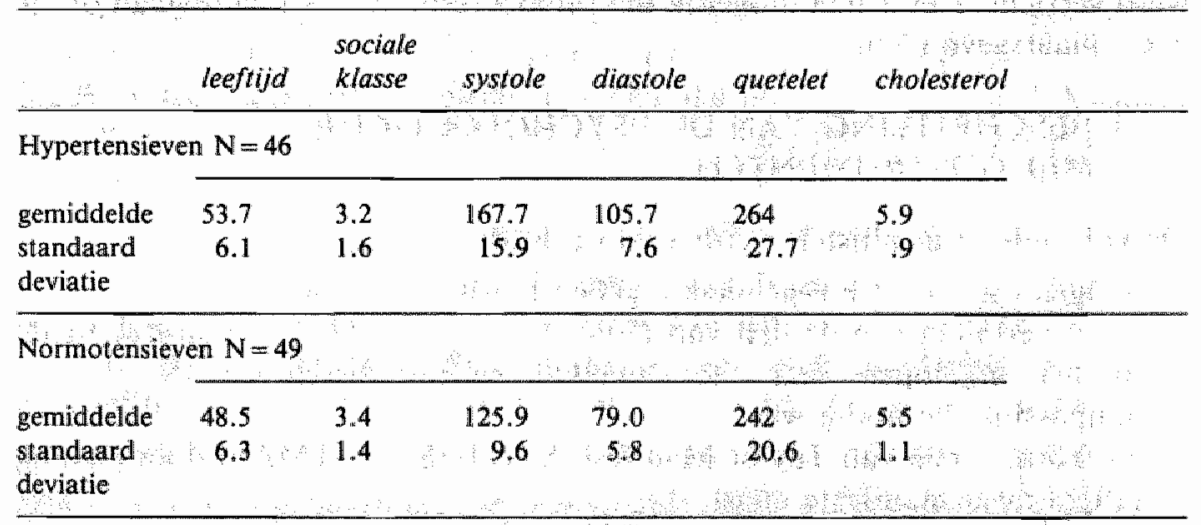

In het theoretische gedeelte in hoofdstuk 2 is er op gewezen dat de relatie tussen psychosociale factoren en hypertensie 'verstoord' kan worden door verschillende variabelen. Als mogelijke confounders (verstoorders) kunnen worden opgevat leeftijd en quetelet-index. De variabele leeftijd zal binnen ons onderzoek als covariaat bij de verschillende statistische analyses betrokken worden.

Tevens is door onder andere Schalling (1984) en Steptoe (1985) opgemerkt dat het noodzakelijk is om binnen de hypertensiepopulatie te differentiëren met 
betrekking tot gebruik van hypotensieve medicatie en duur van de hypertensie.

Teneinde na te gaan of hypertensieven die hypotensieve medicatie gebruiken zich psychologisch onderscheiden van hypertensieven die geen medicijnen gebruiken, is de totale groep hypertensieven alsvolgt opgesplitst:

- Subgroep hypertensieven met medicatie: HYPMED.

- Subgroep hypertensieven die geen medicatie ontvangt: HYPZONDER.

Tevens wordt de groep hypertensieven opgesplitst naar de duur van de hypertensie:

- Een subgroep hypertensi even met een verhoogde bloeddruk die reeds langer dan 2 jaar aanwezig is: HYPLANG.

- Een subgroep hypertensieven bij wie de bloeddruk niet langer dan 2 jaar verhoogd is : HYPKORT.

Met betrekking tot deze laatste indeling naar duur van de hypertensie dienen we enkele kanttekeningen te maken. De indeling komt tot stand op grond van het antwoord op de vraag. "Hoe lang geleden is het dat bij u hoge bloeddruk werd ontdekt"? Aangezien een te hoge bloeddruk jarenlang ongemerkt aanwezig kan zijn is het antwoord op bovengestelde vraag pas valide als bij de respondenten periodiek (minstens 1 maal per jaar) een bloeddrukmeting werd verricht. Het is niet mogelijk om bij alle respondenten na te gaan of dit heeft plaatsgevonden.

\subsubsection{BESCHRIJVING VAN DE PSYCHOLOGISCHE MEETINSTRUMENTEN}

De volgende vragenlijsten werden voorgelegd:

a. Vragenlijst recent meegemaakte gebeurtenissen (VRMG), eigen vertaling van de lijst van Holmes en Rahe (1967): inventariseert de in het afgelopen jaar meegemaakte gebeurtenissen en de vereiste aanpassing die nodig was.

b. Verkorte versie van Taylor Manifest Anxiety Scale (TMAS) door Bendig (1956) meet manifeste angst.

c. Eysenck Personality Inventory (EPI), vertaling van de lijst van Eysenck (1964) conform de formulering van de betreffende items zoals opgenomen in de Amsterdamse Biografische Vragenlijst (ABV): meet neuroticisme en extraversie.

d. Leidse Lijst van Sociale Situaties (LLSS) ontwikkeld door De Groot en Walburg (1977): meet de angst of spanning voor sociale situaties en de mate waarin die situaties worden uitgevoerd.

e. Internal-external locus of control (I-E scale) van Rotter(1966) in een vertaling van Rodenburg (1974): meet beheersingsoriëntatie.

f. Jenkins Activity Survey (JAS) in een vertaling van Appels (1979): meet het type A-gedragspatroon. 
g. Defense Mechanism Inventiory (DMI) van Gleser en Ihilevich (1969) in een vertaling van Passchier (1986): meet diverse defensie mechanismen.

De vragenlijsten worden in de volgende paragrafen uitgebreider besproken. Hierbij gaan we, voor zover van toepassing, verder in op de hypothetische constructen en worden enkele relevante psychometrische eigenschappen besproken.

\subsubsection{VRAGENLIJST RECENT MEEGEMAAKTE GEBEURTENISSEN (VRMG, versie 1)}

Met behulp van de 'life chart' van Wolf ontwierpen Holmes en Hawkins de 'Schedule of Recent Experience' (SRE) (Hawkins e.a., 1957).

Men kon hiermee aangeven welke gebeurtenissen de voorgaande 10 jaar hadden plaatsgevonden en wanneer. De gebeurtenissen die in de SRE genoemd worden, representeren een breed spectrum van gebeurtenissen, onderverdeeld in de categorieën: gezondheid, gezin en familie, werk, persoonlijke en sociale omstandigheden en financiën. Met deze lijst kon echter alleen het aantal gebeurtenissen vastgesteld worden.

Holmes en Rahe (1967) bewerkten de oorspronkelijke versie en ontwikkelden een vragenlijst, waarmee de mate van 'life change' en de sociale aanpassing konden worden gemeten: de Social Readjustment Rating Questionnaire (SRRQ). De onderzoekers veronderstelden, dat het gemeenschappelijk aspekt van alle in de SRRQ omschreven gebeurtenissen is, dat het voorkomen ervan een zogenaamd adaptief - of copinggedrag van de betrokkene vereist.

Holmes en Rahe namen vervolgens de SRRQ af op een groep gezonde personen, met het doel voor elke afzonderlijke gebeurtenis een standaardscore te kunnen bepalen. De respondenten kregen de instruktie, voor elke op de lijst voorkomende gebeurtenis de gemiddelde mate van noodzakelijke sociale anpassing te bepalen en dit in een getal uit te drukken.

Aan de hand van de uiteenlopende scores van de individuele respondenten, kon voor iedere gebeurtenis een gemiddelde waarde worden berekend.

De waarden worden 'Life Change Units' (LCU's) genoemd en vormen een maat waarmee scores van individuele respondenten op de SRE kunnen worden vergeleken.

In prospektief onderzoek met de SRRQ bleek de samenhang tussen de objektieve schatting van de aanpassing en gezondheid echter laag (Rahe e.a., 1974).

Om deze reden heeft Rahe de Recent Life Changes Questionnaire RLCQ ontwikkeld (Rahe, 1978), waarbij de door de repondent subjektief ervaren aanpassing centraal staat. Deze lijst is door ons vertaald en aangepast aan de 
Nederlandse situatie. Voor een gedetailleerde bespreking ervan verwijzen we naar Van Kuilenburg (1980).

\subsubsection{TAYLOR MANIFEST ANXIETY SCALE (TMAS, in verkorte versie van Bendig):}

het meten van manifeste angst

Taylor (1953) ontwikkelde de 'Manifest Anxiety Scale' (MAS). Angst wordt hierbij voorgesteld als 'emotional reactivity or excitability'. In deze visie heeft angst een motivationele functie. De 50 items van de MAS zijn afkomstig van een grote itempool bestaande uit 200 items van de MMPI.

Door Bendig (1956) is een verkorte en verbeterde versie gemaakt van de MAS. De correlatie tussen de TMAS en de verkorte Bendig-versie bleek in de betreffende proefgroep van 744 respondenten hoog te zijn namelijk .93. De interne consistentie, gemeten volgens Cronbach alpha was .76. Hoe hoger de score, hoe angstiger men is.

De vragenlijst is in het Vlaams vertaald en psychometrische gegevens zijn te vinden in Nuttin en Beuten (1977). De begripsvaliditeit bleek goed met de Engelse versie overeen te komen en de interne consistentie gemeten volgens Cronbach was voldoende. De meeste items van de Manifeste Angst Schaal zijn ook opgenomen in de Nederlandse MMPI en de formulering wijkt op enkele plaatsen enigszins af. Vanwege de goede vergelijkbaarheid met onderzoeksresulaten van deze veelgebruikte MMPI hebben wij besloten om de betreffende formulering van de items over te nemen. De interne betrouwbaarheid van de schaal hebben we berekend en de Cronbach alpha was .89 .

\subsubsection{EYSENCK PERSONALITY INVENTORY (EPI) het meten van extraversie en neuroticisme}

De Eysenck Personality Inventory is een gewijzigde versie van de Maudsley Personality Inventory. Het is een verkorte versie en meet extraversie en neurotiscisme (Eysenck, 1964). Een extravert persoon is naar buiten gericht, sociaal gemakkelijk in de omgang, is impulsief, heeft vele sociale contacten en neemt vaak deel aan groepsactiviteiten. Aan het andere eind van deze schaal staat de introverte persoon. Introvert is iemand die nogal teruggetrokken is, introspectief, gereserveerd is en geen impulsieve stappen en beslissingen neemt. Hoe hoger de score hoe extraverter men is.

Een hoge score op de Neurotiscisme schaal duidt op een emotionele instabiliteit en grote prikkelbaarheid.

Volgens Eysenck verklaren de twee dimensies, extraversie-introversie en neuroticisme-stabiliteit het overgrote deel van de variantie in de persoonlijkheid. Hij heeft hierover een uitgebreide theorie, de 'inhibitie- 
theorie', geformuleerd, die we hier verder niet zullen bespreken.

De EPI telt 12 items. De meeste van deze items zijn opgenomen in de Amsterdamse Biografische Vragenlijst. We hebben deze Nederlandse vertaling van de items overgenomen. De betrouwbaarheidscoëfficiènten, gemeten met de Cronbach alpha, bedroeg voor de schaal Extraversie" slechts .59 en voor de schaal 'Neuroticisme' .75 .

\subsubsection{LEIDSE LIJST SOCIALE SITUATIES (LLSS) \\ het meten van sociale angst}

In de loop van de tijd zijn aan het begrip 'assertiviteit' verschillende betekenissen toegekend. Sub-assertief gedrag wordt veelal beschreven in termen van angst, die ervaren wordt in interpersoonlijke conflictsituaties en die het uitdrukken van ware gevoelens en het vertonen van adequaat, effectief gedrag verhindert.

Een bredere definitie wordt door de Moor en Orlemans (1972) gegeven. Assertief gedrag wordt omschreven als reakties in de intermenselijke relatie, waarbij iemand zich op een normale wijze laat gelden, zelfbewust is, voor zijn mening uitkomt, voor zijn rechten opkomt, zich niet in een hoek laat drukken, uiting durft te geven aan positieve gevoelens van vriendschap, liefde en genegenheid. Tenslotte vermelden we nog de omschrijving van assertiviteit door Van Son (1978): "het omgaan met anderen, niet gehinderd of verhinderd door angst om met die ander om te gaan en zodanig dat het op korte en lange termijn leidt tot overwegend positieve gewenste gevolgen, zonder dat anderen er onterecht door benadeeld worden' (Van Son, 1978, p. 7).

Het begrip assertiviteit is de laatste jaren enorm verbreed. Bleef de omschrijving in eerste instantie beperkt tot 'opkomen voor jezelf' en 'nee kunnen zeggen', momenteel wordt er veel nadruk gelegd op het nemen van positief (of toenaderings-)gerichte gedragingen als het uitspreken van waardering of het kunnen tonen van onzekerheild (Arrindell e.a, 1984).

Bij gebrek aan een voor Nederland te gebruiken assertiviteitsschaal hebben Kraaimaat, Van Dam, de Groot en Walburg een schaal geconstrueerd waarbij werd uitgegaan van de bovenbeschreven definities van assertiviteit van de Moor en Orlemans, en Van Son (de Groot en Walburg, 1977).

Er werden naast het meten van angst of spanning voor sociale situaties ook vragen gesteld over het daadwerkelijk voorkomen van sociaal adequaat gedrag. Er werd een itempool geconstrueerd van 750 items waarop vervolgens een inhoudsanalyse werd uitgevoerd. De items waren afkomstig van Nederlandse en buitenlandse meetinstrumenten van (sub)assertief gedrag. Er werd gewerkt met een 8-tal categorieën die het begrip assertiviteit zouden dekken. Deze a priori indeling bleek ook in het empirisch materiaal terug te vinden te zijn. 
De gedragscategorieën zijn:

1. contact initiëren,

2. negatieve feedback geven,

3. positieve feedback geven,

4. weigeren van onredelijke verzoeken,

5. omgaan met positieve feedback,

6. omgaan met negatieve feedback,

7. aandacht en hulp vragen,

8. eigen mening nalar voren brengen.

De LLSS-versie die wij gebruiken bevat 47 items die tweemaal gescoord worden op een 5-puntsschaal. Eenmaal voor de mate van ervaren spanning/angst als men het beschreven gedrag zou ervaren (schaal LLSS'spanning'), en de tweede keer voor de frequentie waarmee men het betreffende gedrag uitvoert (schaal LLSS-'frequentie'). Een hoge score op de LLSS-spanning staat voor een hoge sociale angst. Een hoge score op de LSSSfrequentie staat voor een hogere frequentie waarmee sociale situaties wordt uitgevoerd. Psychometrische gegevens zijn samengevat in de Groot, Walburg (1977). De hoge betrouwbaarheidscoëfficiënten (Cronbach alpha .90) worden ook in ons onderzoek aangetroffen.

(De LLSS is nadat ons onderzoek was gestart verder bewerkt en in een iets gewijzigde versie onder de naam Schaal voor Interpersoonlijk Gedrag gepubliceerd (Arrindell, de Groot, Walburg, 1984). Slechts een enkel item is toegevoegd zodat vergelijking van de LLSS met de SIG goed mogelijk is).

\subsubsection{INTERNE-EXTERNE LOCUS OF CONTROL (IE): het meten van beheersingsoriëntatie}

De persoonlijkheidsfactor 'interne gerichtheid' ofwel de Anglo-Saksiche term 'internal-external locus of control', komt voort uit de sociale leertheorie van Rotter (1966). De theorie beoogt menselijk gedrag in concrete probleemsituaties te verklaren en te voorspellen. Gedrag wordt bepaalld door verwachtingen, cognities en bekrachtiging. Gedrag in sociale situaties wordt geleerd doordat het beloond wordt. Het effect van die beloningen is echter afhankelijk van de mate warin de persoon een causale relatie tussen zijn eigen gedrag en de beloning percipièert. Door generalisatie van specifieke naar algemene situaties, ontstaat er een verwachting ten aanzien van de causale relatie tussen eigen gedrag en de gevolgen daarvan.

Men verschilt, zegt Rotter (1966) in de mate waarin men gelooft zelf invloed of controle uit te kunnen oefenen op het bereiken van bepaalde doelen. $\mathrm{Zij}$, die geloven dat factoren zoals geluk, kans, lot, of machtige anderen, bepallend zijn voor het bereiken van het doel, worden EXTERNEN genoemd. INTERNEN daarentegen zijn mensen die een causaal verband leggen tussen eigen gedrag en de gevolgen daarvan. $\mathrm{Zij}$ denken invloed te kunnen uitoefenen op hetgeen hen overkomt. 
Om deze interne-externe gerichtheid of wel beheersingsoriëntatie te kunnen meten ontwikkelde Rotter een vragenlijst, de zogenaamde Locus of control scale.

Het begrip interne-externe controle is door Rotter gedefiniëerd als de gegeneraliseerde verwachting omtrent de mate van controle over het optreden van bekrachtigingen. Bij de constructie van de vragenlijst ging hij ervan uit dat twee soorten generalisaties optreden: generalisatie van verwachtingen die betrekking hebben op verschillende bekrachtigingen in dezelfde soort situaties, generalisatie van ervaringen in zeer verschillende situaties met betrekking tot dezelfde soort bekrachtigingen.

Deze I-E lijst van Rotter is door Rodenburg (1974) vertaald en bestaat uit 29 iterns, waarvan er 6 bij de scoring niet meetellen, de zogenaamde filler-items. Bij elk item moet men uit twee uitspraken er één kiezen waarvan men vindt dat die het beste past bij de eigen manier van leven en denken. Het gaat hierbij om een keuze tussen een interne of een externe beheersingsoriëntatie. De extern gescoorde items worden opgeteld en vormen de score op de vragenlijst. Een hoge score staat derhalve voor een externe gerichtheid.

Rodenburg (1974) geeft resultaten van twee studies waaruit blijkt dat de I-E lijst een redelijke mate van interne consistentie bezit.

Ook ten aanzien van de validiteit zijn er enige kanttekeningen te maken. In het overzichtswerk van Halfens (1985) wordt duidelijk dat betwijfeld kan worden of het begrip 'locus of control' wel een-dimensioneel is. Verschillende factoranalyses van de Rodenburg versie tonen aan dat er meer dimensies aanwezig zijn.

De vragenlijst is door ons afgenomen bij ongeveer 700 respondenten die deelnamen aan een bevolkingsonderzoek in Krimpen a.d. Jssel ter opsporing van hoge bloeddruk (Schreurs en Corpeleijn, 1977). Factoranalyses (Varimax PA2) bij zowel vrouwen als mannen leverden 3 redelijk goed interpreteerbare factoren op. De interne consistentie van de gehele lijst was echter vrij hoog (betrouwbaarheidscoëfficiënt Cronbach alpha is .79) zodat is besloten de lijst niet onder te verdelen in subschalen.

\subsubsection{JENKINS ACTIVITY SURVEY (JAS): \\ het meten van type-A-gedragspatroon}

In paragraaf 2.6.5 is het concept van type-A gedragspatroon" uitvoerig beschreven. Dit gedrag kan door middel van een gestructureerd interview valide worden bepaald. Dit interview is ontwikkeld door de ontdekkers van het zogenaamde 'coronary prone behavior pattern', de cardiologen Friedman en Rosenman.

Ook met behulp van een vragenlijst is dit gedragspatroon valide te meten: $\mathrm{Er}$ 
zijn diverse lijsten beschikbaar (ook Nederlandstalig) zoals de Framingham Type-A scale, Sales type-A measure, Bortner scale (zie voor beschrijvingen Van Bastelaer en Van Beers, 1982). De meest geschikte vragenlijst is de Jenkins Activity Scale (JAS) yanwege het feit dat deze theoretisch goed is gefundamenteerd (Jenkins, Rosenman, Friedman, 1967).

De JAS meet het zogenaamde type-A gedrag dat wordt gedefinieerd als een chronische, niet aflatende strijd om steeds meer te bereiken in steeds minder tijd, en als het nodig is dat te doen tegen alle tegenwerkende krachten of personen in. De belangrijkste kenmerken van dit gedragspatroon zijn: gejaagdheid, haast, ambitie, agressivitiet, het gevoel onder de druk van de tijd te leven, prestatiegerichtheid en een hoge mate van werkbetrokkenheid (Appels, 1979).

Type-B personen vertonen dit gedrag in veel mindere mate. Het type-A gedragspatroon is strikt genomen geen persoonlijkheidstrek, maar een verzameling overte gedragingen die uitsluitend in de aanwezigheid van de juiste uitlokkende situationele factoren wordt opgewekt (Glass, 1977, Price, 1982).

De JAS heeft in de loop van zijn ontwikkeling verschillende versies gekend. Als uitgangspunt voor de Nederlandse bewerking heeft Appels (1979) de derde Amerikaanse versie gekozen. Deze versie bestond uit 64 items waarvan er enkele zo typisch Amerikaans waren, dat zij a priori niet in de Nederlandse bewerking konden worden opgenomen. De lay-out van de vragen werd gewijzigd om de beantwoording en de verwerking te vergemakkelijken. Jenkins en Zyzanski hadden de JAS zodanig gecontrueerd dat deze naast een algemene type-A schaal ook drie factoren bevatte, die op zichzelf een mogelijke cardiovasculaire relevantie hadden. Deze schalen zijn 'Speed and lmpatience' (S), 'Job Involvement' (J) en 'Hard driving and competitive' $(H)$. De validiteit van deze drie subschalen blijkt enjgszins tegen te vallen (zie handleiding JAS, Appels, 1985), zodat deze indeling voor de Nederlandse bewerking niet werd nagestreefd.

Volgens de constructeurs van de lijst representeren de items van de schaal het construct type-A vrij goed. Een hoge score wijst op een gedragspatroon dat gekenmerkt wordt door haastigheid en gejaagdheid, door activiteit en betrokkenheid op het werk, door ambitie en een gemakkelijk prikkelbaar en vurig temperament.

Het aspect agressiviteit is echter zwak gerepresenteerd, evenals het aspect vijandigheid (Appels, 1985).

Wij maken gebruik van de JAS in de vertaling van Appels. De lijst bestaat uit 36 items met twee tot vijf antwoordalternatieven. Met behulp van een latente structuuranalyse kunnen aan de antwoorden op de 36 items gewichten worden toegekend, zodat een totaalscore berekend kan worden: de A/B 
latente trekscore. Ervaringen met deze ingewikkelde scoring zijn niet onverdeeld gunstig. In een eigen onderzoek hebben we zowel de latente trekscore berekend alswel een sterk vereenvoudigde scoring toegepast. Hierbij worden alle scores op de 36 items omgezet in een 5-puntsschaal; een hoge score correspondeert met type-A gedrag en een lage score representeert meer het type-B gedrag. De Pearson-correlatie tussen beide scoringen bleek erg hoog, namelijk .96 .

\subsubsection{DEFENSIEMECHANISMEN LIJST (DMI):}

het meten van defensie-mechanismen

De 'defense mechanism inventory' is ontwikkeld door Gleser en Thilevich (1969) en in het Nederlands vertaald door Passchier e.a. (1986). In samenwerking met Van de Willige hebben wij de lijst verder aangepast aan de Nederlandse situatie. De DMI is bedoeld om een betrekkelijk groot aantal defensie-mechanismen te meten. Bij het samenstellen van de test is uitgegaan van de gedachte dat defensiemechanismen ten doel hebben om innerlijke conflicten (conflicten tussen wat de persoon waarneemt en de geinternaliseerde waarden) op te lossen.

De defensie-mechanismenlijst is een vrij ongewone test. Hij bevat 10 situatieschetsen rondom de thema's autoriteit, onafhankelijkheid, mannelijkheid of vrouwelijkheid, competitie en situationeel bepaalde conflicten. De keuze voor deze gebieden motiveren Gleser en Ihilevich (1969) vanuit de veronderstelling dat het hier gaat om belangrijke menselijke conflicten waarmee de meeste mensen in aanraking zijn geweest of waarvan men kan aannemen dat zij zich deze makkelijk kunnen voorstellen. Dit is van belang om verschillen in de persoonlijke voorkeur van gehanteerde defensiemechanismen te kunnen signaleren.

Bij iedere beschrijving worden 20 verschillende responsmogelijkheden gegeven verdeeld over 4 groepen. De eerste groep bevat items betreffend actueel gedrag in de beschreven situatie, de tweede groep items verwijzen naar gedrag in fantasie, de derde groep betreft items aangaande gedachten die men in de beschreven situatie heeft en de laatste categorie gaat over gevoelens die men ervaart tijdens de geschetste gebeurtenis. De respondent moet nu binnen iedere groep aangeven welk item het beste weergeeft hoe men handelt, fantaseert, denkt, en voelt (pluspunt). Tevens geeft men ook aan welk item van deze 4 groepen dit het minst doet (minpunt). Het totaal aantal pluspunten minus het aantal minpunten geeft dan een maat van de consistentie van iemands defensies over de verschillende niveaus (actueel gedrag, fantasiegedrag, gedachten en gevoelens).

De defensiemechanismen worden in de volgende groepen opgesplitst:

- 'Turning Against Object? (TAO); het conflict wordt opgelost door zich tegen het object te keren, dat als bedreigend of frustrerend wordt gezien. 
Defensiemechanismen als identificatie met de agressor en "displacement" vallen hieronder.

- Projectie ("Projection", PRO); hieronder vallen defensies, die agressie tegen een extern object rechtvaardigen door er negatieve bedoelingen of karakteristieken aan toe te kennen.

- Principalization' (PRN); in deze groep defensies worden conflicten aangepakt door het toepassen van het algemene principe van 'afsplitsing': bij innerlijke conflicten wordt het gevoel van de inhoud gescheiden en vervolgens onderdrukt, zoals het geval is bij defensiemechanismen als intellectualisatie, rationalisatie en isolatie.

- 'Turning against self", (TAS): het conflict wordt aangepakt door de agressie tegen zichzelf keren. Defensies als masochisme en autosadisme zijn ondergebracht.

- 'Reversal' (REV); 'omkering', waarin defensiemechanismen als ontkenning, negeren, overdekking door het tegendeel opgenomen zijn, die alle inhouden dat er op positieve of neutrale wijze wordt gereageerd op objecten die naar verwacht mag worden, bij vele mensen een negatieve reactie op kunnen roepen.

Voor psychometrische gegevens van de DMI yerwijzen we naar Gleser en Ihilevich (1969), Juni (1982) en voor wat betreft de Nederlandse versie naar Passchier e.a. (1986). Gedetailleerde gegevens over de door ons aangepaste versie van de DMI staan vermeld in Brosschot (1985). We volstaan hier met de opmerking dat de interne consistentie van de 5 schalen, berekend met de Cronbach alpha, varieerde van .65 tot 85 . De schalen werden berekend middels een factanalyse (Varimax). Met betrekking tot de validiteit zijn echter nog te weinig gegevens voorhanden om conclusies te trekken.

De intercorrelaties tussen de DMI-schalen zoals berekend over 105 personen met een gemiddelde leeftijd van 50 jaar, staan hieronder vermeld:

Tabel 5.2. Intercorrelaties DMr-schalen

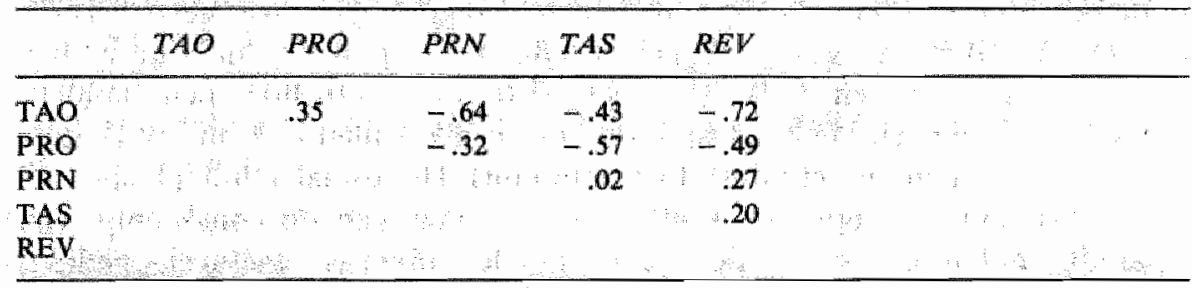

De correlaties tussen de schalen geven nagenoeg hetzelfde beeld zoals gepresenteerd door Gleser en Thilevich (1969): een contrast tussen enerzijds de schalen TAO en PRO en anderzijds de schalen PRN en REV. TAO en PRO betreffen vooral defensies waarbij affectregulatie naar buiten is gericht 
('acting out gedrag') terwijl bij PRN en REV er eerder sprake is van een repressie van affect.

Juni (1982) creëerde een nieuwe schaal die een betere predictor bleek te zijn van de reactie op frustratie. De schaal, de composietschaal genoemd, werd samengesteld uit de subschalen TAO + PRO-PRN-REV. Het betreft een continuum met aan de ene kant defensiemechanismen die duiden op een expressie van agressie en aan de andere kant staan defensiemechanismen die deze agressie naar buiten inhiberen: externalisatie versus internalisatie.

In ons onderzoek zullen we naast de originele 5 schalen van de DMI eveneens gebruik maken van de samengestelde schaal TAO/PRO die het zogenaamde 'acting out gedrag' kan meten en van de door Juni (1982) geïntroduceerde composietschaal.

\subsubsection{INTERCORRELATIES PSYCHOSOCIALE VARIABELEN}

Bij een statistische toetsing op univariaat niveau van de verschillen in scores op de persoonlijkheids vragenlijsten tussen hyper-en normotensieven, kunnen de variabelen leeftijd en in sommige gevallen de variabelen sociaaleconomische klasse als mogelijke verstoorders van de samenhang opgevat worden. Het is bekend dat leeftijd een sterk verband vertoont met de bloeddruk. Aangezien de onderzoeksgroepen hyper- en normotensieven sterk verschillen in gemiddelde leeftijd zal via een covariantie-analyse deze variabelen als covariaat worden opgenomen.

De variabelen leeftijd, quetelet-index en sociaal-economische klasse kunnen echter ook een samenhang vertonen met de persoonlijkheidsvragenlijsten. Om dit nader te onderzoeken hebben we Pearson-correlaties berekend tussen de variabelen leeftijd, quetelet-index en sociaal-economische klasse enerzijds en de verschillende persoonlijkheidsvragenlijsten anderzijds. We hanteren een significatieniveau van $5 \%$.

De leeftijd speelt met name een rol bij de JAS: het type-A gedrag neemt kennelijk iets aan kracht af bij het klimmen der jaren. Daarentegen is er een significante positieve correlatie met 'Reversal'. Met de subschaal 'spanning" van de LLSS (LLS) en met de I-E schaal correleert de leeftijd in beperkte mate en niet significant.

De sociaal-economische klasse speelt zoals te zien in tabel 5.3 bij diverse vragenlijsten een rol van betekenis. De correlaties met de JAS $(r=.27)$, met de I-E ( $r=-.38)$ en met 'Reversal' $(r=-.36)$ zijn significant: een hogere sociaaleconomische klasse gaat gepaard met type-A gedrag, terwijl men een interne beheersingsorientie heeft en minder vaak gebruik maakt van het defensiemechanisme "Reversal".

Tenslotte valt uit tabel 5.3 op te maken dat de quetelet-index significant correleert met de schaal 'Reversal', De correlaties met extraversie $(r=.22)$ en met TAO $(\mathrm{r}=-.20)$ zijn niet significant. 
Tabel 5.3. Pearson correlaties tussen de variabelen leefijd, sociabl-economische klasse en met de verschillende persoonlijkheids wragenlijstem.

\begin{tabular}{|c|c|c|c|}
\hline varlabele & leefiujd & soctate klasse & quetelet \\
\hline \multicolumn{4}{|l|}{ LLSS (souciale angst) } \\
\hline - Spanning & .14 & -.16 & -.04 \\
\hline - Frequentie & -.03 & .14 & .05 \\
\hline \multicolumn{4}{|l|}{ EPI } \\
\hline - Extraversie & -.02 & -.12 & $.22 *$ \\
\hline - Neuroticisme & -.02 & -.16 & -.06 \\
\hline JAS (A-type) & -.20 & $.27 * *$ & .02 \\
\hline TMAS (angst) & -.09 & -.07 & .02 \\
\hline $\begin{array}{l}\text { I-E (beheersings- } \\
\text { orientatie) }\end{array}$ & -.12 & $-.38^{* * * *}$ & -.05 \\
\hline VRMG (gebeurtenissen) & -.01 & -.12 & .05 \\
\hline \multicolumn{4}{|l|}{ DMI } \\
\hline - Turning Against Object & -.20 & .12 & -.20 \\
\hline - Projection & -.09 & .11 & -.09 \\
\hline - Principalization & .03 & .19 & .06 \\
\hline - Turning against self & .05 & -.08 & .01 \\
\hline - Reversal & $.27 * *$ & $-.36 * * *$ & $.28^{* *}$ \\
\hline
\end{tabular}

Een algemene conclusie die getrokken kan worden uit bovenstaande, is dat de scores op enkele psychologische vragenlijsten nogal beinvloed worden door leeftijd en de sociale klasse waartoe men behoort.

Een ander probleem met betrekking tot de analyse van zoveel variabelen is, dat we te maken hebben met onderling afhankelijke metingen en dat rekening moet worden gehouden met een samenhang van de variabelen. In tabel 5.4 hebben we de intercorrelaties samengevat.

Tabel 5.4. Intercorrelaties russen enkele persoonlijkheids-vragenlijsten

\begin{tabular}{|c|c|c|c|c|c|c|c|}
\hline variabele & $L L S$ & $L L F$ & EXTRA & NEURO & $J A S$ & $T M A S$ & $I-E$ \\
\hline LLS (sociale angst) & - & $-.30 * *$ & $-.36^{* * *}$ & $.40^{* * * *}$ & .17 & $.49^{* * *}$ & .10 \\
\hline LLF (frequentie angst) & & - & $.25^{* *}$ & .12 & $.32 * *$ & .06 & $-.25^{*}$ \\
\hline EXTRAVERSIE & & & - & $.30^{* *}$ & .12 & $-.36 * * *$ & -.15 \\
\hline NLUROTICISME & & & & - & $33^{* * * *}$ & $.79 * *$ & .15 \\
\hline JAS (A-type) & & & & & - & $.39 * * *$ & $-.27 * *$ \\
\hline TMAS (angst) & & & & & & 一 & .15 \\
\hline
\end{tabular}

$* \mathrm{p}<.05 \quad * * \mathrm{p}<.01 \quad * * \mathrm{p}<<.001$

De subschaal 'spanning' van de LLSS, die de ervaren spanning tijdens sociale situaties meet, correleert hoog met de andere angstschaal, TMAS $(r=.49)$. De subschaal 'frequentie' van de LLSS die de frequentie meet waar in het 
betreffende gedrag wordt uitgevoerd correleent met het type-A gedrag $(\mathrm{r}=.32)$.

Extraversie correleert met Neuroticisme met een $r$ van .30 en met LLSSspanning een $r$ van -.36 , en met TMAS een $r$ van -.36 .

De Neuroticisme-score komt sterk overeen met de score op de TMAS $(r=79)$ en de score op de $\operatorname{LLS}(r=.40)$ en in mindere mate met extraversie $(r=.30)$ en het type-A gedrag $(r=.33)$.

Het type-A gedrag correleert behalve met angst $(\mathrm{r}=39)$ ook met neuroticisme $(r=.33)$ en de frequentie-schaal van de LLSS $(r=32)$. Verder kunnen we een significant verband $(r=.27)$ constateren tussen type-A gedrag en een interne beheersingsorientatie.

De angstschaal (TMAS) correleert hoog (Pearson $r=.49$ ) met de ervaren spanning tijdens sociale situaties (LLS), met neuroticisme $(r=.79)$ en er is ook een significante correlatie met introversie $(r=.36)$ en het type-A gedrag $(r=.39)$.

In tabel 5.5 zijn de correlaties tussen de DMI-schalen en de overige vragenlijsten samengevat.

Tabel 5.5. Correlaties tussen enkele persoonlijkheids-vragenlijsten en de subschalen van de DMI

\begin{tabular}{lccccc}
\hline variabele & $T A O$ & $P R O$ & $P R N$ & $T A S$ & $R E V$ \\
\hline LLS (sociale angst) & .01 & -.20 & -.15 & $.30^{* *}$ & .04 \\
LLF (frequentie angst) & -.04 & -.06 & -.03 & .01 & .13 \\
EXTRAVERSIE & -.04 & .08 & .12 & -.18 & .04 \\
NEUROTICISME & .04 & -.11 & $-.26^{*}$ & $.24^{*}$ & .06 \\
JAS (A-type) & $.26^{*}$ & .12 & -.18 & -.10 & -.20 \\
TMAS (angst) & .06 & -.10 & -.19 & .20 & -.01 \\
1-E (beheersing) & .05 & .04 & -.13 & -.01 & .02 \\
\hline
\end{tabular}

* $p<.05 * n<.01$

Bestudering van de correlaties van de verschillende DMI-schalen met de overige persoonlijkheids-vragenlijsten kan ertoe bijdragen dat we een beter inzicht krijgen in de begripsvaliditeit van de DMI, een lijst die althans in Nederland niet veel wordt gebruikt. 'Turning against others' (TAO), (zich tegen iets keren dat als bedreigend wordt gezien) correleert met het A-type gedrag $(r=.26)$ hetgeen conform de verwachting is. De subschaal principalisatie' (bij innerlijke conflicten wordt het gevoel gescheiden van de inhoud en dit gevoel wordt vervolgens onderdrukt) correleert negatief met neuroticisme $(r=-26)$ en TMAS $(r=-.19)$. De subschaal TAS (de agressie tegen zichzelf keren), correleert 30 met de subschaal spanning', net introversie $(r=18)$, met neuroticisme $(r=25)$ en angst $(r=22)$. De laatste subschaal 'Reversal', (omkering ofwel ontkenning), correleert -20 met de JAS. 
Tot sllot de onderlinge samenhang tussen de persoonlijkheidsvragenlijsten met de vragenlijst recent meegemaakte gebeurtensissen (VRMG).

In tabel 5.6 staan alleen de significante Pearson correlaties $(\mathrm{p}=<0.5)$ vermeld met een $\mathrm{r}$ boven .20 , berekend over alle respondenten.

Tabel 5.6. Belangrijkste Pearson correlaties van de subcategorie-van de lijst recent meegemaakte gebeurtenissen (VRMO) met persoowijkheidskenmerken.

aqural gebeurtenissen per categorie

gezondheid

- Neuroticisme $\quad 35$

$1 \mathrm{TMAS} \quad .21$

$-1-\mathrm{E}^{\mathrm{N}}-.33$

werk

Neuroticisme : $\quad .43$

$\triangle$ TMA $\quad .28$

- LLIT: $\quad \therefore \quad .23$

- A/B-type $\quad .30$

- DMI-TAO 21

- DMI-PRN

21
3
43
28
3
30
21
28

aantal gebewrienissen per categorie

persoonlinke omstandigheden

- A/B-type

.36

financiele omstandigheden

- A/B-type

roval aantal gebeurtenissen

- Neuroticisme

.33

- TMAS

- A/Butype

- DML-TAO

- DMI-PRN

$-.27$

- DMI-composiet

Opvallend is dat het aantal meegemaakte gebeurtenissen vaak samengaat met een hogere score voor angst (TMAS) en Neuroticisme. Verder zien we dat type-A personen meer gebeurtenissen meemaken hetgeen conform de verwachting is.

\subsubsection{STATISTISCHE PROCEDURES}

Van de 46 hypertensieven en de 49 normotensieven die in het onderzoek zijn opgenomen, beschikken we over nagenoeg alle gegevens betreffende leeftijd, sociale klasse, quetelet-index en de systolische en diastolische bloeddruk. Alleen de gegevens over het al dan niet gebruiken van bloeddrukverlagende medicijnien en over de duur van de hypertensie, zijn niet altijd met zekerheid vast te stellen. De betreffende analyses met deze variabelen zullen dan ook uitsluitend verricht worden met de goed interpreteerbare data.

Er zijn enkele missende data met betrekking tot de persoonlijkheidsvragenlijsten. Indien er meer dan $10 \%$ van een vragenlijst ontbreekt dan wordt de gemiddelde score op deze lijst voor de betreffende respondent als 'missing data' gedeclareerd. Bij het ontbreken van slechts enkele items van de lijst wordt de gemiddelde score hiervoor gecorrigeerd door de totaalscore te delen door het aantal correct ingevulde items.

Student's t-test voor onafhankelijke metingen wordt toegepast om de groep van hypertensieven te vergelijken met de normotensieven op de variabelen leeftijd, quetelet-index, sociaal economische klasse en cholesterolgehalte: We 
zullen telkens uitgaan van een significantie-niveau van $5 \%$ en een tweezijdige toetsing.

Om de verschillen in scores op de persoonlijkheidslijsten tussen de subgroepen van de hypertensieven te onderzoeken voeren we een variantie-analyse uit (Anova, SPSS-X programmatuur, 1983) met als covariaat de leeftijd.

Om een nauwkeurige analyse te maken van de relatieve discriminatieve waarde van de belangrijkste onafhankelijke variabelen voor hypertensie, hebben we een multivariate discriminant analyse uitgevoerd via stapsgewijze procedure (SPSS-programmatuur). Een discriminant-analyse is een multivariate analyse die het mogelijk maakt om verschillende variabelen tegelijkertijd in de analyse op te nemen. Een discriminant-analyse biedt de mogelijkheid een statistisch onderscheid te maken tussen twee groepen. Men kan nagaan welke variabelen die groepen het best van elkaar onderscheiden. Met deze methode wordt een discriminant-functie berekend waarin de onafhankelijke variabelen een bepaald gewicht krijgen (canonische discriminant functie coëfficiënt). Volgens de stapsgewijze procedure wordt allereerst de best discriminerende variabele geselecteerd. Deze variabele beschrijft de variantie het best en minimaliseert tevens de lambda het meest. Deze Wilks' lambda is een mat voor de voorspellende kracht met betrekking tot de plaatsing van de personen in de hypertensieve of in de normotensieve groep. Naarmate op basis van de score van deze variabele beter voorspeld kan worden in welke groep de persoon hoort, ligt de waarde van lambda dichter bij 0.

Nadat de variabele die het best discrimineert geselecteerd is, wordt gezocht naar een tweede variabele, die het beste in staat is om het onderscheidende vermogen te vergroten. De procedure wordt stopgezet als de resterende variabelen niet meer in staat zijn een significante bijdrage te leveren aan het discriminerend vermogen. Gegeven de discriminant-functie en de individuele scores op de onafhankelijke variabelen waarbij rekening wordt gehouden met de gewichten van de variabelen in de functie, kunnen personen statistisch worden ingedeeld in groepen. Deze statistische indeling kan vervolgens vergeleken worden met de werkelijke indeling.

\subsection{RESULTATEN}

\subsubsection{LEEFTIJD EN QUETELET-INDEX}

Uit gegevens van de bevolkingsonderzoeken in Zoetermeer (Valkenburg, 1980) en Krimpen a/d IJssel (Prins, 1979) is duidelijk aangetoond dat de bloeddruk stijgt met het klimmen der jaren. De leeftijd heeft dus een sterk voorspellende waarde. In tabel 5.7 zien we dat de gemiddelde leeftijd van de groep hypertensieven hoger ligt dan die van de normotensiewen ( $t$-waarde = -4.37 , d.f $=92, p<001$ ). We zullen derhalve bij de toetsing van de hypothesen hiermee rekening dienen te houden. 
Een andere variabele waarvan eveneens een sterke samenhang werwacht mag worden is de quetelet-index. Inderdaad zien we dat deze index significant hoger is bij de hypertensieven in vergelijking met de normotensieven (t-waarde $=-3,99$, d.f. $=79, \mathrm{p}=<.001$ )

Tabel 5.7. De gemiddelde leefijid en quetelet-index wan mormotensieven en hypertensieven en de resultaten van de t-tests:

\begin{tabular}{|c|c|c|c|c|c|c|c|}
\hline & \multicolumn{7}{|c|}{ leefivid } \\
\hline & $N$ & 8 & s.d & twaarde & d.f. & $p$-waarde & \\
\hline \multirow{4}{*}{$\begin{array}{l}\text { normotensiewen } \\
\text { hypertensieven }\end{array}$} & 48 & 48,1 & 6,3 & \multirow{2}{*}{-4.36} & \multirow{2}{*}{92} & \multirow{2}{*}{$<.001$} & \\
\hline & 46 & 53,7 & 6,2 & & & & \\
\hline & \multicolumn{6}{|c|}{ quetelet-index } & \\
\hline & $N$ & $x$ & $s . d$ & & & & \\
\hline normotensieven & 49 & 24,3 & 2,1 & \multirow{2}{*}{-3.99} & \multirow{2}{*}{79} & \multirow[t]{2}{*}{$<.001$} & \\
\hline hypertensieven & 45 & 26,4 & 2,9 & & & & \\
\hline
\end{tabular}

\subsubsection{PSYCHOLOGISCHE VERSCHILLEN TUSSEN SUBGROEPEN HYPERTENSIEVEN}

Op grond van de argumenten aangedragen in paragraaf 5.1.1. zijn de hypertensieven opgesplitst in subgroepen naargelang de hypertensie korter of langer dan 2 jaar aanwezig is (HYPKORT versus HYPLANG), Eveneens maken we een indeling in twee subgroepen van hypertensieven op grond van het feit dat de hypertensieven al dan niet bloeddrukverlagende medicatie gebruiken (HYPMED versus HYPZONDER).

Allereerst is onderzocht of de subgroepen HYPMED en HYPZONDER van elkaar verschillen in persoonlijkheidskenmerken zoals deze door ons zijn gemeten via vragenlijsten. Om deze verschillen te toetsen voeren we een variantieanalyse uit met als covariaat leeftijd.

In tabel 5.8 staan de resultaten weergegeven. Naast de gemiddelde scores op de persoonlijkheids-vragenlijsten geven we tevens enkele relevante gegevens betreffende leeftijd, quetelet-index en de bloeddruk.

De resultaten vatten we kort samen: De verschillen met betrekking tot de subgroepen HYPMED en HYPZONDER zijn statistisch net niet significant voor de scores op de lijst Extraversie en de lijst Neuroticisme. Hypertensieven die medicijnen gebruiken zijn lets meer extraverter en iets minder "neurotisch" dan de hypertensieven die geen medicijnen gebruiken. Ook rapporteert de subgroep HYPZONDER meer recent meegemaakte gebeurtenissen maar ook dit verschil met subgroep HYPMED is statistisch niet siginificant. Indien we bovenstaande variantie-analyses uitvoeren met én leeftijd én quetelet-index als covariaten, dan veranderen de $\mathbf{F}$-waarden nauwelijks. $\mathrm{De} F$-waarden 
Tabel 5.8 Gemiddelde leeftijd, quetelet, cholesverol en bloeddruk en de gemiddelde scores op de persoonlijkheidsuragenlijsten voor de subgroepen HYPMED en HYPZONDER (hypertensieven met en zonder bloeddruk-verlagende middelen), Verschillen zijn getoetst met varianiti-analyse met als covariaat de leefrija.

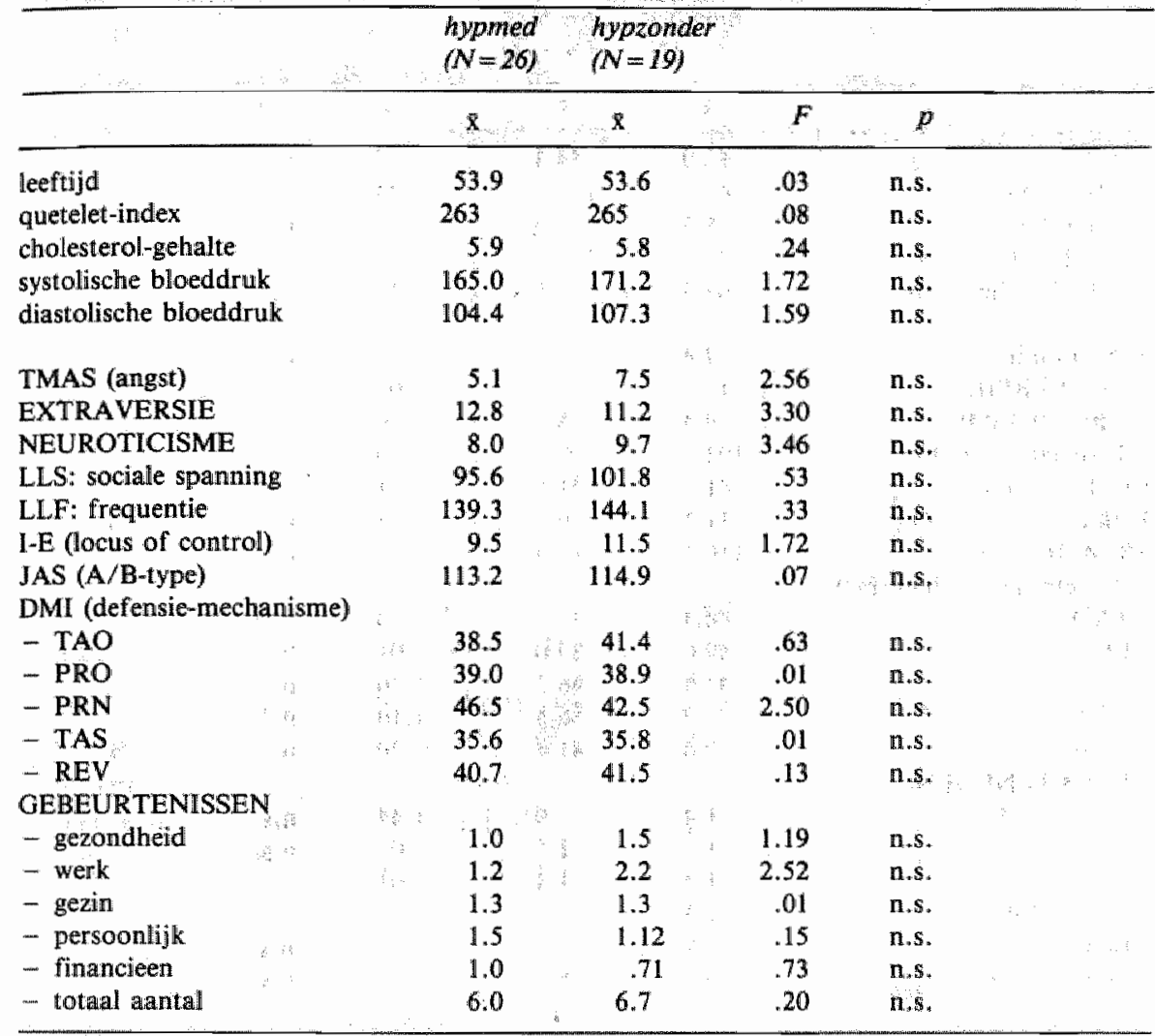

behorende bij de schalen Neuroticisme, Extraversie en Gebeurtenissen vallen iets lager uit.

De verschillen in persoonlijkheidskenmerken tussen de hypertensie groepen HYPLANG en HYPKORT zijn eveneens zeer gering. De resultaten staan vermeld in de volgende tabel.

Alleen op de subschaal van de Defensie-mechanismelijst is er een verschil tussen beide groepen dat het significantie-niveau benaderd. De gemiddelde score op de DMI-schaal TAO ('turning against object') van personen met een hypertensie korter dan 2 jaar bedraagt 44.3 en van degenen bij wie de hypertensie langer dan 2 jaar bestaat $37.0(\mathrm{~F}=2.90, \mathrm{p}=09)$. Indien we bovenstaande variantie-analyse uitvoeren met zowel leeftijd én quetelet-index als covariaten, dan veranderen de $\mathrm{F}$-waarden nauwelijks. Alleen de $\mathrm{F}$-waarden behorende bij de DMI-schalen TAO en REV worden statistisch significant 
Tabel 5.9 Gemiddelde leefijid, quetellet, cholesterol en bloeddruk en de gemiddelde scores op de persoonlijkheidswragentijsten voor de subgroepen HYPKORT en HYPLANG (hypertensieven met respectiewelijk een verhoogde bloeddruk korter of langer dan 2 jaar, Verschillen zijn getoetst via variantie-analyse met als covariaat de leefild.

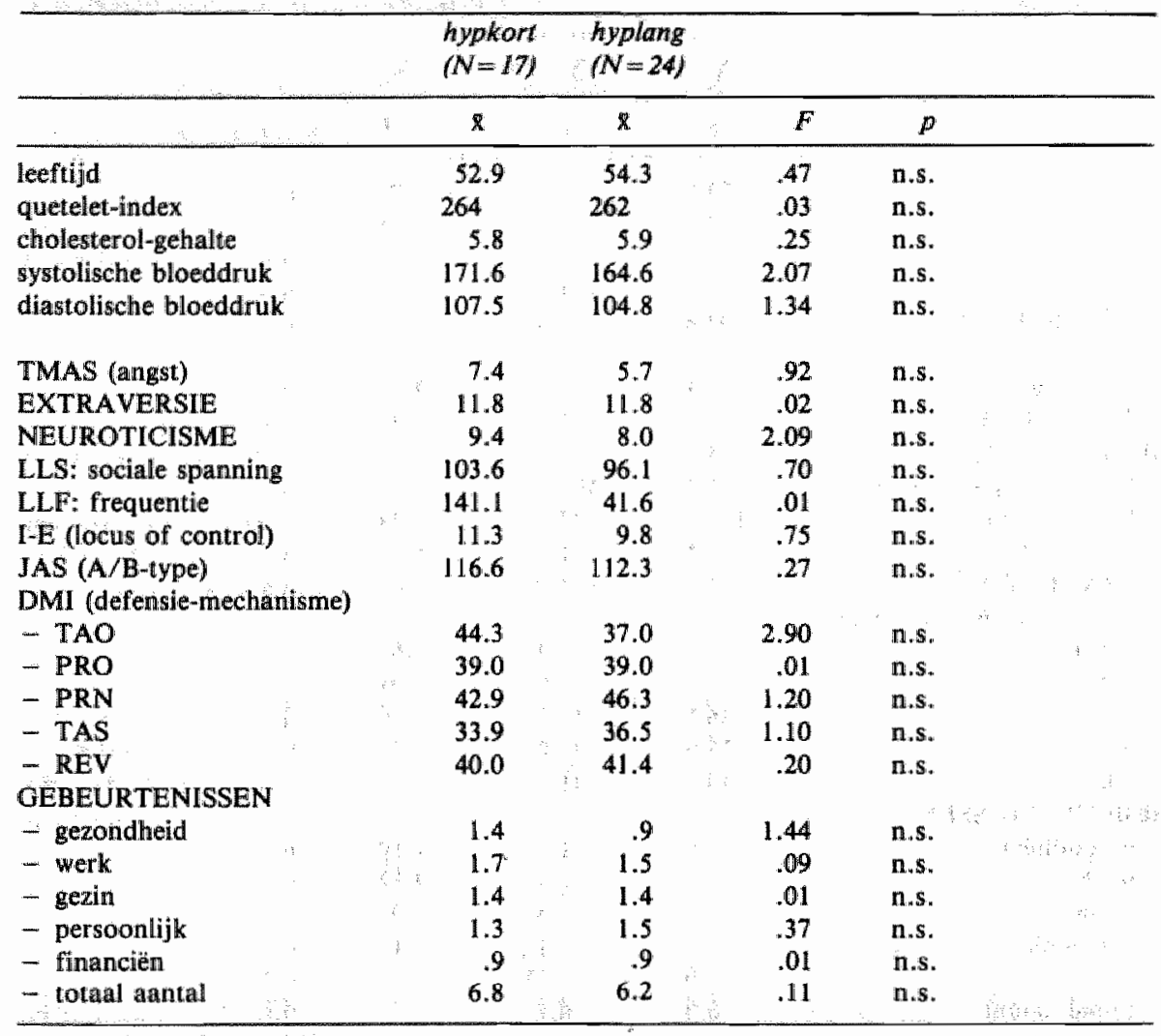

$(p<0.5)$. Het geeft een tendens weer dat hypertensieven, bij wie recent de bloeddruk is verhoogd, hun agressie meer naar buiten keren. Omtrent de mogelijke theoretische impliclaties voor de etiologie van hypertensie komen we in paragraaf $5: 2.3 .2$ terug.

\subsubsection{PSYCHOLOGISCHE VERSCHILLEN TUSSEN HYPERTENSIEVEN EN NORMOTENSIEVEN}

\section{5,2.3.1 LEVENSGEBEURTENISSEN}

We zijn geïnteresseerd in de vraag of hypertensieven het afgelopen jaar meer dan wel minder gebeurtenissen hebben meegemaakt en hoeveel aanpassing deze gebeurtenissen vergden. Het aantal gebeurtenissen dat men meemaakt kan namelijk verband houden met bepaalde gedragskenmerken, Overigens moet er rekening mee worden gehouden dat er duidelijke verschillen bestaan 
tussen jongere en oudere mensen met betrekking tot het meernaken danwel rapporteren van gebeurtenissen. We hebben hierover elders uitvoerig gerapporteerd (Van de Willige, Schreurs, Tellegen en Zwart, 1985).

In tabel 5.10 hebben we het aantal gebeurtenissen vermeld yoor zowel de hypertensieven als de normotensieve groep, waarbij er een covariantie-analyse is uitgevoerd, met als covariaat de leeftijd.

Tabel 5.10. Gemiddelde score van aantal gebeurtenissen per subcategorie voor hypertensieven en normotensieven, en de resultaten wan de wariantie-analyse met als covariat de leeflija.

\begin{tabular}{|c|c|c|c|c|}
\hline$\therefore$ & $\begin{array}{l}N=46 \\
\text { hyper } \\
\text { tensiewen }\end{array}$ & $\begin{array}{l}N=49 \\
\text { nommo- } \\
\text { temsieven }\end{array}$ & $F$ & $\begin{array}{llll}+5 & \\
p & \end{array}$ \\
\hline aantal gezondheidsgebeurtenissen & 1.2 & .7 & 2.2 & 16 \\
\hline werkgebeurtenissen & 1.6 & 1.0 & 3.3 & .07 \\
\hline gezinsgebeurtenissen & 1.3 & .9 & 1.3 & .26 \\
\hline persoonlijke gebeurtenissen & 1.3 & 1.4 & 3 & a \\
\hline financiële gebeurtenissen & 9 & .6 & 5.5 & $\quad 02$ \\
\hline totaal aantal gebeurtenissen & 6.2 & 4.5 & 4.7 & .03 \\
\hline
\end{tabular}

Het blijkt dat hypertensieven het afgelopen jaar vaker bepaalde gebeurtenissen hebben meegemaakt dan normotensieven.

Tegenover gemiddeld 6.2 gebeurtenissen staan er 4.5 voor de normotensieve groep $(F=4.75, p=.031)$. We constateren tevens een verschil in gerapporteerde gebeurtenissen betreffende financien als we naar de verschillende subcategorieen kijken. Toetsing van bovenstaande verschillen met zowel leeftijd én quetelet-index als covariaten, levert geen verandering in resultaten op.

Er is ook getoetst of de beide groepen verschillen in de totale aanpassing die deze gebeurtenissen vergden. In onderstaande tabel staan de resultaten van de covariantie analyse (covariaat leeftijd).

Tabel 511. Som yan de aanpassingsseore per subcategorie yoor hypertensieven en normotensieven en de resultaten van de variantie-analyse met als covariaat de leeftijd.

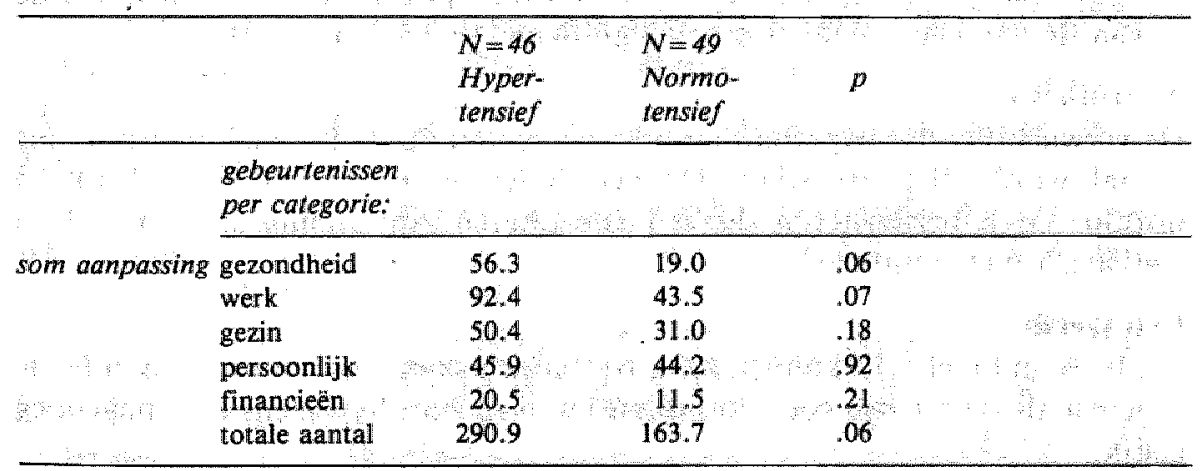


We zien een gering verschil tussen de som van de aanpassingsscores op de gebieden gezondheid, werk en het totaal aantal gebeurtenissen. Toetsing van deze verschillen met leeftijd én quetelet als covariaten levert geen ander resultaat. Resumerend kunnen we stellen dat hypertensieven iets meer gebeurtenissen rapporteren dan normotensieven en dat er een tendens is dat deze gebeurtenissen een hogere aanpassingsscore met zich meebrengen.

\subsubsection{PERSOONLIJKHEIDSKENMERKEN}

In paragraaf 2.3.4 hebben we onderzoeksresultaten besproken betreffende de relatie tussen persoonlijkheidskenmerken en hypertensie. Een voorzichtige conclusie was dat er geen duidelijkheid bestaat over de vraag of hypertensieven zich van normotensieven onderscheiden wat betreft de persoonskenmerken extraversie, sociale angst, beheersingsoriëntatie en type A gedrag en defensiemechanismen. Wel zijn er aanwijzingen dat er een verschil is in de mate van angst en neuroticisme: Hypertensieven zouden angstiger zijn en hoger scoren op de Neuroticisme-lijst in vergelijking met normotensieven. Het is echter niet uitgesloten dat deze kenmerken ook bij personen met andere psychosomatische klachten worden aangetroffen.

We toetsten of hypertensieven zich van normotensieven onderscheiden door hogere scores op extraversie, angst en subassertiviteit, beheersingsoriëntatie, type A gedrag, neuroticisme en de verschillende defensiemechanismen.

In onderstaande tabel 5.12 worden de resultaten weergegeven van de covariantie-analyse waarbij leeftijd als covariaat is opgenomen.

\section{Angst}

Als angstmaat nemen we de score op de verkorte versie van de 'Taylor Manifest Anxiety' schaal (zie 5.1.3.2). De verwachting dat hypertensieven hoger op deze schaal scoren wordt bevestigd. Hypertensieven hebben een gemiddelde score van 6.1 en normotensieven een gemiddelde van 4.0 ( $F=$ $7.95, \mathrm{p}=.006$ ). Corrigeren we voor zowel leeftijd als quetelet, dan wordt de F-waarde iets lager maar nog wel significant $(\mathrm{F}=5.2, \mathrm{p}=.03)$.

\section{Neuroticisme}

De verwachting dat hypertensieven hoger scoren op de Eysenck-neuroticisme schaal wordt niet bevestigd. De verschillen in neuroticisme-score tussen normo- en hypertensieven die wij constateren zijn weinig substantieel en statistisch niet significant.

\section{Extraversie}

Zoals we in tabel 5.12 kunnen zien, treffen wij geen verschil aan tussen beide groepen: de scores zijn voor normotensieven en voor hypertensieven nagenoeg gelijk. 
Tabell 5.12. Gemididelde scores op de persoonlijkheidswragenlijsten van hyper-en normotensieven en de resultaten van de variantie analyses met als covariaat de legtüd.

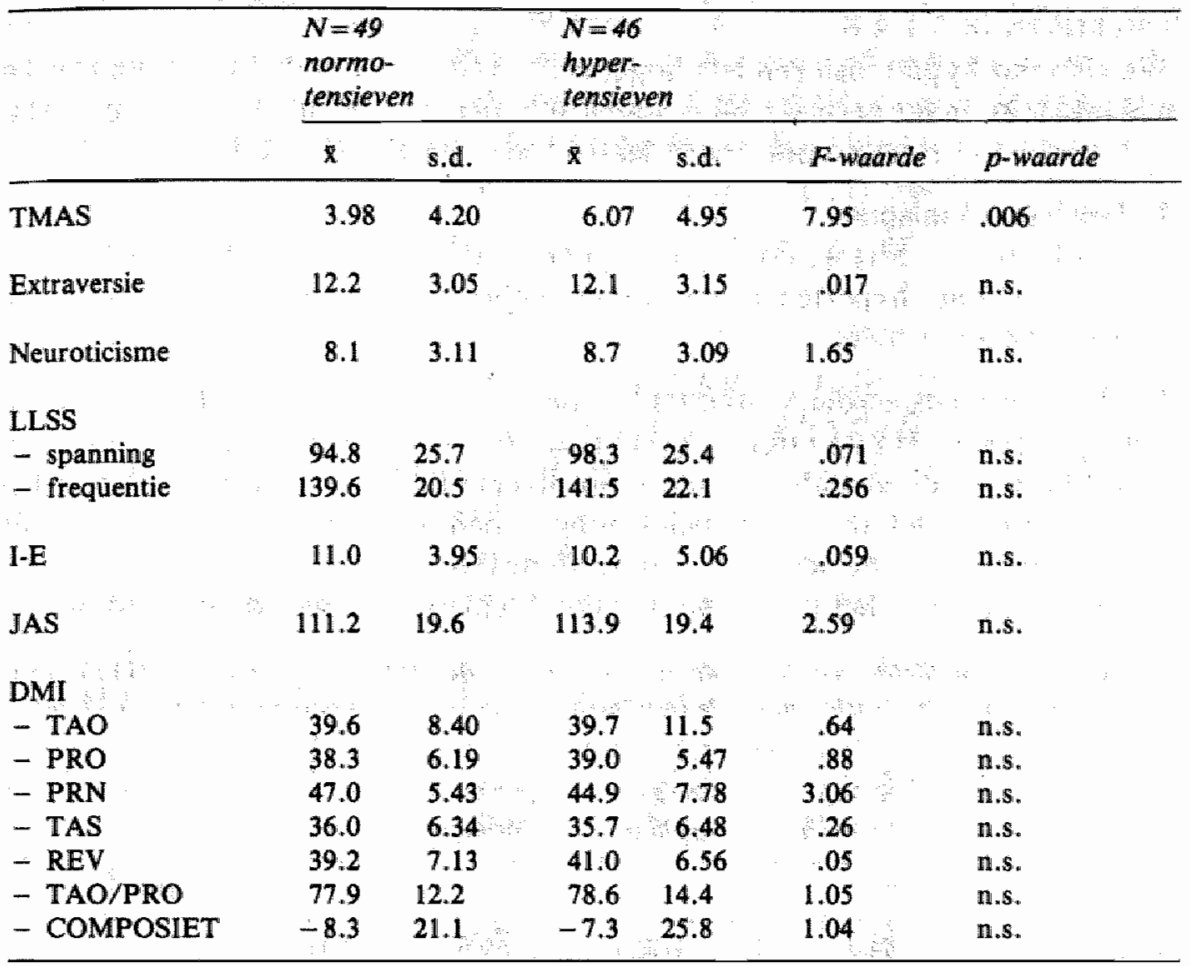

\section{Assertiviteit}

De mate van assertiviteit meten we met de Leidse Lijst Sociale Situaties (LLSS) zoals we die beschreven in 5.1.3.4.

De scores op de schaal 'spanning' van de LLSS verschillen niet tussen hyperen normotensieven. De gemiddelde scores bedragen respectievelijk 94.8 en 98.3 ( $\mathrm{F}=.071$, n.s.).

Ook de schaal 'frequentie' van deze lijst discrimineert niet tussen beide groepen. Normotensieven hebben een gemiddelde score van 139.6 versus hypertensieven met een score van $141.5(F=.256, \mathrm{n} . \mathrm{s}$.$) .$

\section{Beheersingsoriëntatie}

Als maat voor het meten van het begrip 'locus of control' ofwel beheersingsoriëntatie gebruiken we zoals vermeld in 5.1.3.5 de Nederlandse vertaling van de Rotter I-E lijst.

In tabel 5.12 zien we dat hypertensieven slechts een fractie interner scoren $(X=10.2)$ dan normotensieven $(X=11.0)$. Dit verschil is, gecorrigeerd voor leeftijd, niet significant. Correctie voor zowel leeftijd én quetelet levert geen ander resultaat $(\mathrm{F}=.23, \mathrm{p}=\mathrm{n.s}$. $)$. 


\section{Type-A gedragspatroon}

In ons onderzoek maken we gebruik van de Jenkins Activity Survey zoals beschreven in 5.1.3.6.

We zien dat hypertensieven iets hoger scoren $(X=113.9)$ dan normotensieven $(\mathrm{X}=111.2)$, maar het verschil is statistisch niet significant $(\mathrm{F}=2.59, \mathrm{p}=.11)$, ook niet na correctie voor zowel leeftijd als quetelet $(F=2.4, p=n . s$.$) .$

\section{Defensiemechanismen}

In hoofdstuk 3 'Stress, coping en hypertensie', hebben we de mogelijkheid besproken dat hypertensieven vaker gebruik maken van verschillende defensiemechanismen.

We hebben reeds eerder vastgesteld in par, 5.2.2 dat er tussen de subgroepen hypertensieven HYPKORT en HYPLANG geringe verschillen zijn met betrekking tot de gemiddelde score op diverse DMI-schalen. Om deze reden willen wij de indeling in deze beide subgroepen handhaven om ze vervolgens te vergelijken met de scores van normotensieven.

In onderstaande tabel geven we de gemiddelden weer van de drie groepen.

Tabel 5.13. Gemiddelde scores op de subschalen van de DMI van de groepen HYPKORT, HYPLANG en normotensieven, en de resultaten van de variantie-analyses met als covariaat de leeftijid.

\begin{tabular}{llcccc}
\hline & $\begin{array}{l}N=12 \\
\text { hypkort }\end{array}$ & $\begin{array}{l}N=22 \\
\text { hyplang }\end{array}$ & $\begin{array}{l}N=48 \\
\text { normo's }\end{array}$ & & \\
& & 7 & & $F$ & $p$-waarde \\
\hline TAO & 44.3 & 37.0 & 39.6 & 2.41 & n.s. \\
PRO & 39.0 & 39.0 & 38.3 & .45 & n.s. \\
PRN & 42.9 & 46.3 & 47.0 & 2.40 & n.s. \\
TAS & 33.9 & 36.5 & 36.0 & .77 & n.s. \\
REV & 40.0 & 41.4 & 39.2 & .10 & n.s. \\
TAO/PRO & 83.3 & 76.0 & 779 & 1.64 & n.s. \\
COMPOSIET & 4 & -11.7 & -8.3 & 1.44 & n.s. \\
\hline
\end{tabular}

Nadere bestudering van bovenstaande tabel leidt tot de conclusie dat er een redelijk verschill is in gemiddelde scores op de DMI-schalen TAO en PRN, tussen hypertensieven bij wie de bloeddruk nog niet langer dan 2 jaar verhoogd is versus de normotensieven. Deze hypertensieven zijn dus meer geneigd dan normotensieven om hun agressie naar buiten te richten, getuige de hogere scores op de subschaal TAO. Het verschil is echter statistisch net niet significant $(\mathrm{p}=.09)$ maar wél na correctie voor leeftijd én quetelet. Tevens maken zij minder gebruik van de defensiemechanismen rationalisatie of wel intellectualisatie. Dit is ook wel te verwachten gezien de hoge negatieve correlatie van - 67 tussen de schalen TAO en PRN. Ook dit verschil tussen de 3 groepen is statistisch niet significant $(p=10)$. Na correctie voor leeftijd én quetelet wordt de F-waarde wel net significant $(\mathrm{p}<05)$.

De personen in de groep HYPKORT bewegen zich over het algemeen op de 
composietschaal, met als continuüm internalisatie-externalisatie, iets meer in de richting van externalisatie dan normotensieven, $\mathrm{Zij}$ hebben meer dan normotensieven de neiging om conflicten op te lossen door zich tegen een reëel of veronderstell extern frustrerend object te keren en hebben minder de neiging om conflicten op te lossen door gebruik te maken van het principe van 'afsplitsing", waarbij het gevoel van de inhoud wordt gescheiden en vervolgens onderdrukt. Indien we de variantie-analyse uitvoeren met leeftijd én queteletindex als covariaten, dan wordt ook deze $F$-waarde statistisch significant $(\mathrm{p}=<.05)$.

Samenvattend kunnen we stellen dat hypertensieven en normotensieven niet verschillen in gemiddelde scores op de volgende persoonlijkheidswragenlijsten: beheersingsoriëntatie (I-E), type-A gedragspatroon (JAS), neuroticisme (EPI$\mathrm{N}$ ), extraversie (EPI-E) en assertiviteit (SIG). Er is alleen sprake van een hogere angstscore op de betreffende vragenlijst.

We constateren dat hypertensieven meer recent meegemaakte gebeurtenissen rapporteren. Dit verschil wordt voornamelijk veroorzaakt door de hogere scores op de VRMG van de groep hypertensieven die pas kort (niet langer dan 2 jaar) een verhoogde bloeddruk heeft.

Een gering verschil in gedragspatroon zien we met betrekking tot de gehanteerde defensiemechanismen zoals gemeten met de DMI. Met name de personen die kort een verhoogde bloeddruk hebben richten hun agressie meer naar buiten.

We zullen in hoofdstuk 7 nader terugkomen op de resultaten van deze univariate analyses.

\subsubsection{SUBGROEPEN HYPERTENSIEVEN}

Om nader te analyseren welke psychologische variabelen een relatief voorspellende waarde hebben voor hypertensie, is een multivariate discriminantanalyse uitgevoerd via stapsgewijze procedure (SPSSprogramma Discriminant, methode Wilks). De discriminant-anallyse gaat na welke variabelen hypertensie het best van normotensieven kan onderscheiden. Er wordt een discriminant-functie berekend waarin de onafhankelijke variabelen een bepaald gewicht krijgen (canonische discriminantfunctie coëfficient). Gegeven de discriminantfunctie en de individuele scores op de onafhankelijke variabelen waarbij rekening wordt gehouden met de gewichten van de variabelen in de functie, kunnen personen statistisch worden ingedeeld in groepen. Deze statistische indeling kan vervolgens vergeleken worden met de werkelijke indeling.

De discriminant analyse is uitgevoerd over 12 variabelen: naast de leeftijd en het gewicht, de persoonlijkheidskenmerken en het aantal recent meegemaakte gebeurtenissen. Uiteindelijk werden 5 variabelen opgenomen in de 
discrïminantfunctie namelijk leeftijd, quetelet, TMAS (angst), I-E (interne beheersingsoriẻntatie) en TAO/PRO ('acting out gedrag').

In onderstaande tabel zijn de resulltaten samengevat.

Tabel 5.14. Discriminamt analyse met als afhankelike variabele hypertensie.

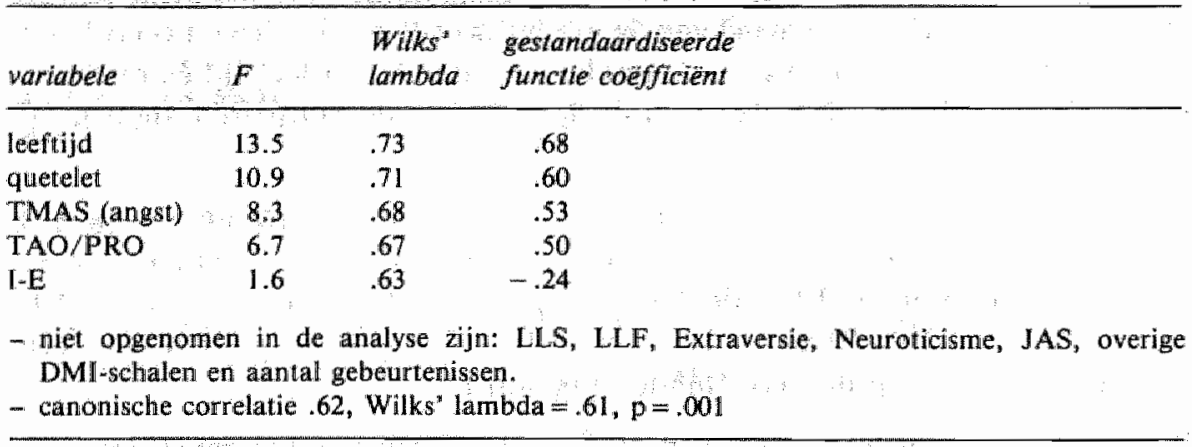

De Wikinsons lambda, omgezet tot een chi-square score is significant. Ook de canonische correlatie-coëfficiënt die is op te vatten hoe goed beide groepen van elkaar gescheiden kunnen worden middels de betreffende variabelen, is redelijk. $39 \%$ van de proportie variantie in de discriminantfunctie wordt door de variabelen verklaard. Hiervan nemen echter de variabelen leeftijd en quetelet-index het grootste gedeelte voor hun rekening.

De capaciteit van de gestandaardiseerde canonische discriminant functie is redelijk goed. Van alle respondenten wordt $77 \%$ correct ingedeeld. Van de normotensieven zijn er 46 in de analyse opgenomen en van hen wordt $81 \%$ correct in de normotensieve groep geplaatst. Van de 36 hypertensieven die zijn opgenomen in de analyse wordt $69 \%$ correct in deze groep geplaatst.

Indien we een discriminant analyse uitvoeren teneinde een onderscheid te maken tussen normotensieven en hypertensieven die pas sinds twee jaar een verhoogde bloeddruk hebben dan zien we een duidelijker statistisch verschil. Middels de zogenaamde stapsgewijze procedure worden er uiteindelijk 6 variabelen in de discriminantfunctie opgenomen, namelijk TAO/PRO, leeftijd, quetelet, TMAS, LLF en aantal gebeurtenissen. De resultaten zijn vervat in tabel 5.15 .

De Wilkinsons lambda is in vergelijking met de eerste analyse aanzienlijk Jager, hetgeen er op duidt dat de variabelen de twee groepen goed kunnen onderscheiden. Ook de canonische correlatiecoefficiënt is zeer significant. Gezamenlijk verklaren de betreffende variabelen die zijn opgenomen in de discriminantfunctie $49 \%$ van de variantie. De capaciteit van de gestandaardiseerde canonische discriminant functie om de hypertensieven en de normotensieven correct te classificeren is $96 \%$; van de hypertensieven wordt $82 \%$ correct geplaatst en van de normotensieven wordt zelfs $100 \%$ juist geplaatst. 
Tabel 5.15. Discriminant analyse met als afhankelijke variabele hypertensie korter dan 2 jaar

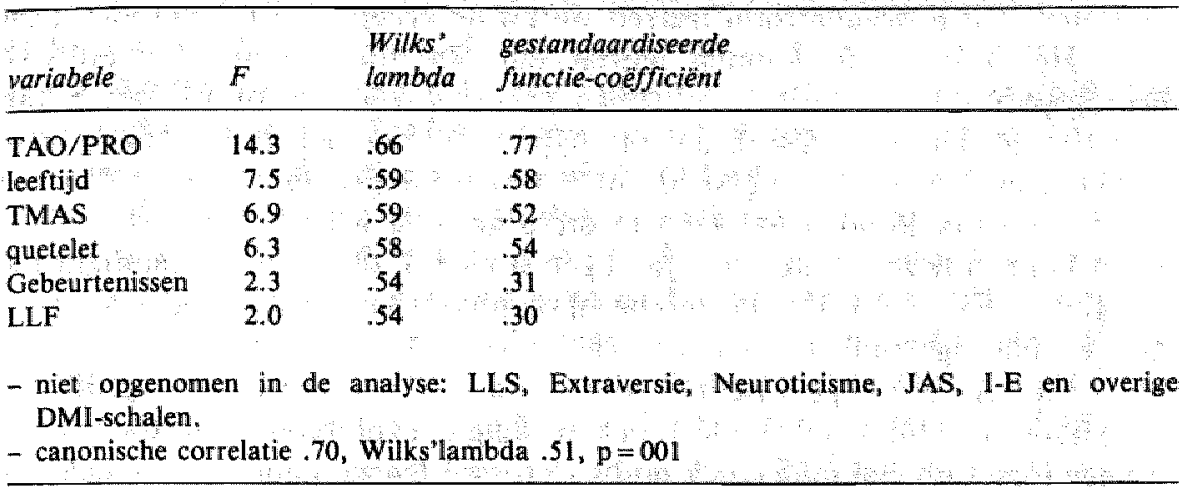

In hoofdstuk 4 hebben we geconstateerd dat er mogelijkerwijs sprake is van verschillende subgroepen van hypertensieven met betrekking tot persoonskenmerken.

We formuleerden de hypothese dat binnen de groep hypertensieven zich een subgroep zou onderscheiden die gekarakteriseerd zou kunnen worden door een zogenaamd compulsief gedragspatroon. We operationaliseerden dit gedrag door een angstig type-Agedrag, met een hoge boosheidsdispositie en een 'acting out gedrag' waarbij de agressie naar buiten zou worden gericht. In bovenstaande discriminant analyse waarbij we hebben gekeken welke psychologische variabelen een zo goed mogelijk onderscheid kunnen maken tussen normotensie en hypertensie korter dan 2 jaar is dit "compulsief" gedragspatroon gedeeltelijk terug te vinden. We zien dat de hypertensieven angstiger zijn en dat zij eventuele conflicten eerder oplossen door zich tegen het betreffende object te keren. Het verdient aanbeveling om deze vraagstelling verder te onderzoeken.

In hoofdstuk 4 is eveneens de mogelijkheid geopperd van het bestaan van een subgroep hypertensieven die hun emoties onderdrukken en het bestaan van problemen en van aanpassing vereisende gebeurtenissen ontkennen dan wel bagatelliseren. Zij zouden positiever of neutraler reageren op situaties en gebeurtenissen die bij andere mensen vaak een negatieve reactie oproepen. Reeds bij de bespreking van de resultaten met betrekking tot de VRMG (de lijst recent meegemaakte gebeurtenissen), werd echter duidelijk dat hypertensieven over het algemeen meer gebeurtenissen rapporteren dan normotensieven. Het gemiddeld aantal gebeurtenissen lag significant hoger bij een gelijke spreiding. Ook de gemiddelde aanpassingsscore is voor de hypertensieven hoger.

Als we de subschalen van de DMI bekijken en rekening houden met de subgroepen HYPKORT en HYPLANG, dan valt echter wel een onderscheid ten opzichte van de normotensieven te constateren. Personen in de groep 
HYPKORT vertonen een tendens om iets meer 'acting out' gedrag te vertonen. Dit gedragpatroon treffen we bij de groep HYPLANG niet meer aan. Het zou er op kunnen wijzen dat het zogenaamde 'compulsieve gedragspatroon' de basis kan hebben gevormd voor de ontwikkeling van hypertensie. Het is mogelijk dat pre-hypertensieven zich gedurende langere tijd voor problemen zagen gesteld ( meer recent meegemaakte gebeurtenissen) die ze moeilijk konden oplossen (grotere agressie naar buiten). $\mathrm{Na}$ enkele jaren kunnen deze problemen zijn opgelost en zijn de levensomstandigheden ten gunste weranderd. De chronische en onomkeerbare vaatveranderingen die hebben plaatsgevonden, zorgen er echter voor dat de bloeddruk verhoogd blijft vanwege een hogere perifere weerstanden. Het is echter onmogelijk om deze hypothese binnen ons onderzoek grondig te exploreren. Daartoe hebben we een longitudinaal onderzoek nodig ('crossed-lagged panel' onderzoek, zie Marcelissen, 1987), waarbij een groot aantal personen gedurende langere tijd wordt onderzocht.

In het onderzoek dat in het volgende hoofdstuk zal worden beschreven is wederom de vraag gesteld of hypertensieven zich op een aantal persoonlijkheidskenmerken onderscheiden van normotensieven. De hypertensieven die de onderzoeksgroep vormden binnen het BGD-onderzoek waren allen bekend met de door een arts vastgestelde diagnose hypertensie. $\mathrm{Zij}$ stonden dus min of meer geboekt als 'patiënt' ook al kregen zij niet allemaal een medicamenteuze behandeling. Reeds eerder hebben wij erop gewezen dat de 'impact' van deze diagnose mogelijk terug te vinden is in de beantwoording van verschillende persoonlijkheidsvragenlijsten. Zo kan men zich ernstig ongerust maken over de mogelijke consequenties van de te hoge bloeddruk. Men kan zich bewuster worden van zijn leefwijze die kan hebben bijgedragen aan de verhooggde bloeddruk en/of men kan overwegen zijn leefpatroon en zijn copinggedrag te wijzigen. 
In het nu volgende onderzoek participeren we in een periodiek geneeskundig onderzoek voor personeelsleden van de Nederlandse Spoorwegen. In dit onderzoek worden nagenoeg alle personeelsleden om de vijf jaar opgeroepen voor een lichamelijk onderzoek waarbij de bloeddruk op gestandaardiseerde wijze wordt gemeten. Op deze manier is het mogelijk om naast bekende hypertensie' ook respondenten te selecteren bij wie voor het eerst een te hoge bloeddruk wordt geconstateerd en dus niet bekend staan als 'hypertensief'. Behalve een dergelijke uitbreiding met betrekking tot de groep hypertensieven worden er ook een aantal andere factoren bij het onderzoek betrokken. Zo worden de huidige levensomstandigheden van betrokkenen geinventariseerd waaronder zijn woonomgeving, zijn werkbelasting, het sociale netwerk en de ervaren steun. Tenslotte wordt aandacht besteed aan het copinggedrag. 


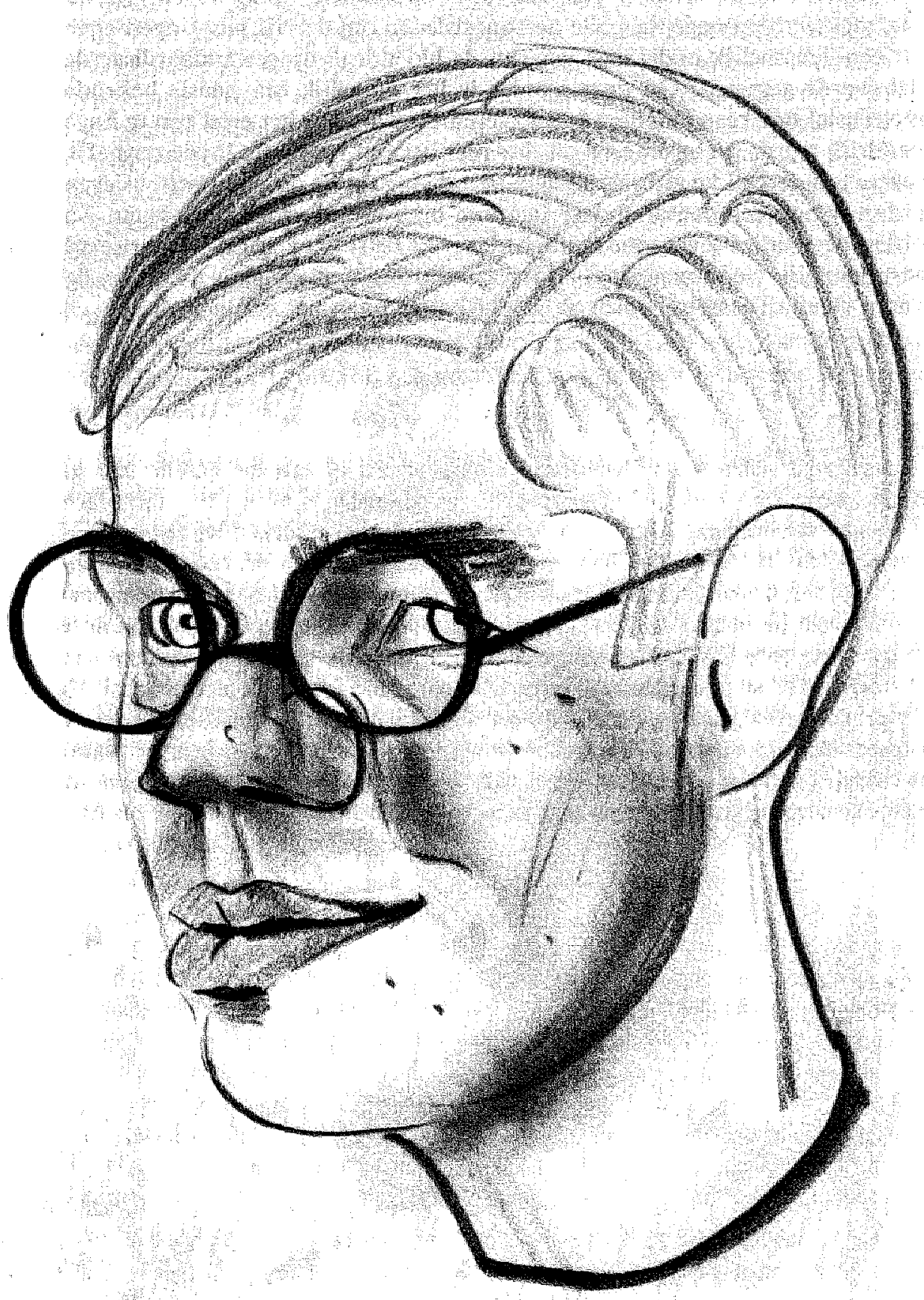




\section{HOOFDSTUK 6}

\section{PSYCHOSOCIALE FACTOREN EN ESSENTIÊLE HYPERTENSIE: Op het spoor van coping; het NS-onderzoek}

\subsection{METHODE}

Het onderzoek is opgezet aan de hand van het multiconditioneel onderzoeksmodel zoals beschreven in Hoofdstuk 4. De te onderzoeken variabelen hebben betrekking op verscheidene onderdelen uit dit model, te weten:

- psychosociale stimuli (aanpassing vereisende gebeurtenissen en problematische levensomstandigheden),

- cognitieve factoren (perceptie en evaluatie van de bedreigende situatie),

- persoonlijkheids- en gedragskenmerken (A/B type, sub-assertiviteit, angsten boosheidsdispositie, beheersingsoriëntatie, defensiemechanismen en copinggedrag).

Het onderzoek is uitgevoerd bij de Nederlandse Spoorwegen (NS), een bedrijf met meer dan 27.000 werknemers en gevarieerde werkterreinen. In het kader van een periodiek bedrijfsgeneeskundig onderzoek, dat om de 5 jaar plaatsvindt, worden personeelsleden van de N.S. medisch gekeurd.

De medische keuring omvat het volgende:

- Bepaling lichaamslengte en -gewicht

- Bloeddrukmeting

- Electrocardiografie

- Bloedchemie (niet nuchter): cholesterol, glucose, S.G.O.T., gamma G.T.

- Longventilatie-onderzoek

- Visuscontrole

- Gehooronderzoek

$\mathrm{Na}$ afloop van de medische keuring is aan personeelsleden afkomstig uit alle functiegroepen om medewerking gevraagd an een onderzoek van de vakgroep Klinische Psychologie van de R.U. Utrecht. Door de medisch assistente werd een korte toelichting gegeven en benadrukt dat de verwerking van de gegevens volledig anoniem zou geschieden. In een korte begeleidende brief van de direkteur van de gezondheidsdienst stond een verdere toelichting over de aard van het onderzoek. Nadat de respondent zijn toestemming had gegeven voor deelname aan het onderzoek, ontving hij een vragenlijstboekje dat thuis kon worden ingevuld. In een bijgesloten enveloppe kon men de ingevulde vragenlijsten terugsturen.

In de periode van september 1981 tot mei 1982 heeft de dataverzameling plaatsgevonden. De keuringen vonden plaats in twee onderzoekscentra: er was 
een permanente onderzoeksplaats in Utrecht en verder was er een tot onderzoeksruimte verbouwde bus beschikbaar die het hele land doortrok. De medewerkers van de centra waren medisch assistenten en analisten met een ruime werkervaring. De medische keuring vond plaats volgens een vast protocol.

Voor een periodieke medische keuring die meestal om de 5 jaar plaatsvindt, worden alleen personeelsleden opgeroepen die deelnemen aan het arbeidsproces. Degenen die langdurig ziek zijn en arbeidsongeschikt komen niet voor een dergelijke keuring in aanmerking.

Aan 1690 personeelsleden met de Nederlandse nationaliteit werd medewerking gevraagd. In totaal hebben 1619 personen het vragenlijstboekje meegenomen waarvan er uiteindelijk 1172 zijn geretourneerd. Volgens gegevens van de medische dienst van de Nederlandse Spoorwegen wijken de bloeddrukwaarden van de niet-respondenten niet af van de respondenten. Met betrekking tot eventuele psychologische verschillen tussen deze groepen zijn geen gegevens beschikbaar.

\subsubsection{HYPOTHESEN}

Op grond van theoretische overwegingen zoals besproken in hoofdstuk 4 en met in achtneming van de resultaten van het hiervoor beschreven onderzoek in hoofdstuk 5, werden de volgende nul-hypothesen geformuleerd:

1. Hypertensieven verkeren niet vaker in belastende levensomstandigheden dan normotensieven: de hypertensieven zijn niet meer ontevreden over hun woonsituatie en hun financiële positie, zij ervaren geen hogere werkbelasting, ontvangen niet minder sociale steun en hun jeugdherinneringen zijn niet minder prettig in vergelijking tot de normotensieven.

2. Er bestaat geen directe relatie tussen essentiële hypertensie en de volgende persoonlijkheidskenmerken:

- type A-gedragspatroon (JAS),

- interne versus externe gerichtheid (I-E lijst),

- assertiviteit (SIG),

- boosheid (ZAV),

- dispositionele angst (ZBV),

- copingmechanismen (UCL),

- defensiemechanismen (DMI)

Verder willen we exploratief nagaan of hypertensieven zijn onder te verdelen in twee subgroepen, die ieder op zich van normotensieven verschillen wat betreft persoonlijkheidskenmerken. Een subgroep hypertensieven kenmerkt zich door een 'compulsief' gedrag. Deze hypertensieven hebben een hoge angstscore en vertonen het type-A gedrag en een actief coping gedrag. 
De andere subgroep kenmerkt zich door een onderdrukking van emoties en door het ontkennen van het bestaan van problemen of belastende gebeurtenissen. Men reageert positiever op situaties en gebeurtenissen die over het algemeen vaak bij anderen een negatieve reactie oproepen. Hierbij worden defensie-mechanismen zoals 'ontkenning' en 'intellectualiseren' en passieve copingstrategieën zoals 'afwachten en vermijden' vaker toegepast, $\mathrm{Ze}$ zijn minder angstig en agressief en hebben een lagere boosheidsdispositie.

\subsubsection{BLOEDDRUKMETING}

De bloeddruk werd op gestandaardiseerde wijze gemeten door ervaren medisch-assistenten met behulp van een zogenaamde random-zero sfygmomanometer. Doordat de kwikkolom een variabel nulpunt heeft, wordt de invloed van de waarnemer op het resultaat van meting niet beïnvloed. Bij alle respondenten is de standaardmanchet gebruikt (maat 23 bij $14 \mathrm{~cm}$ ) volgens de richtlijnen van de Nederlandse Hartstichting.

De bloeddrukmetingen werden verricht onder gelijke omstandigheden en volgens een vast protocol. De bloeddruk werd aan de rechterarm gemeten in liggende positie. De meting werd na ongeveer 10 minuten herhaald. De systolische druk en de diastolische druk (4e en $5 \mathrm{e}$ fase) zijn geregistreerd. In ons onderzoek gaan we voor de bepaling van de diastolische druk uit van de druk die gemeten is in de $5 \mathrm{e}$ fase, conform het advies van de Gezondheidsraad (1983).

Aan de respondenten werd eveneens gevraagd of bij hen ooit een verhoogde bloeddruk is geconstateerd en zo ja, of zij hiervoor momenteel een dieet of medicijnen krijgen voorgeschreven. Tevens werd gevraagd hoe lang de verhoogde bloeddruk, wanneer daarvan sprake, reeds aanwezig is.

\subsubsection{BESCHRIJVING VAN DE STEEKPROEF}

Van de 1690 vragenlijsten zijn er 1172 geretourneerd. De vrouwelijke respondenten zijn uiteindelijk niet opgenomen in de onderzoeksgroep vanwege een te gering aantal. Slechts 61 vrouwen hebben deelgenomen aan het onderzoek. Veertien respondenten hebben een hart- of nierziekte. Hoewel deze ziekte vaak een gevolg kan zijn van een langdurig aanwezige hypertensie, is het echter niet uitgesloten dat de stoornissen aan hart en mieren een verhoogde bloeddruk kunnen veroorzaken, Reden om deze personen niet op te nemen in de onderzoekspopulatie.

Hieronder worden enkele relevante gegevens samengevat van de in het onderzoek betrokken 1097 mannelijke respondenten met de Nederlandse nationaliteit:

Van de respondenten blijkt een ruime meerderheid getrouwd te zijn, namelijk $88 \%$. Ongeveer 9\% geeft aan geen partner te hebben. 


\begin{tabular}{lccc}
\hline variabele & & \multicolumn{1}{c}{ s.d. } & \\
\hline leeftijd & 43.8 & 10.8 & \\
lengte $(\mathrm{cm})$ & 77.4 & 6.5 & \\
gewicht (kg) & 78.3 & 9.9 & \\
quetelet-index & 249 & 28 & \\
cholesterol (mmol/l) & 5.6 & 1.2 & \\
systoilsche bloeddruk eerste meting & 134.2 & 16.0 \\
diastolische bloeddruk eerste meting & 81.8 & 8.7 \\
systolische bloeddruk tweede meting & 129.8 & 14.6 \\
diastolische bloeddruk tweede meting & 81.3 & 8.7 \\
\hline
\end{tabular}

De respondenten vermelden de volgende opleiding te hebben genoten:

\begin{tabular}{ll}
\hline opleiding & percentage \\
\hline - lagere school & 15 \\
- LTS, LEAO, LAVO, ITO & 34 \\
- MULO, MAVO, IVO, 3 jr HBS & 34 \\
- HBS, GYM., ATH., HAVO & 10 \\
- HTS, HEAO, soc. of ped. akademie & 4 \\
- universiteit, hogeschool & 3 \\
\hline
\end{tabular}

De respondenten zijn ook ingedeeld naar sociale klasse. Hierbij is uitgegaan van het classificatieschema zoals dat is ontworpen door het Instituut Toegepaste Sociologie te Nijmegen. Het schema levert de volgende indeling op:

\begin{tabular}{lc}
\hline Sociaal-economische klasse & percentage \\
\hline - ongeschoolde arbeid & 20 \\
- geschoolde arbeid & 10 \\
- lagere employees & 42 \\
- middelbare employees & 22 \\
- hogere beroepen & 6 \\
\hline
\end{tabular}

\subsubsection{CRITERIA VOOR 'HYPERTENSIE' EN 'NORMOTENSIE'}

De bloeddruk werd, zoals vermeld, twee keer gemeten met een tussenpoze van ongeveer 10 minuten. De systolische druk van de eerste en de tweede meting correleerde met een $r$ van .87 (uitgedrukt in Pearsson correlatie). De diastolische waarden correleerden met een $r$ van .93 .

In onderstaande frequentieverdelingen wordt dë bloeddrukdistributie van de betreffende steekproef weergegeven voor de diastolische en de systolische bloeddruk. 
Tabel 6.1. Frequentiewerdeling wan de gemiddelde systolische en de diastolische bloeddruk van alle respondenten

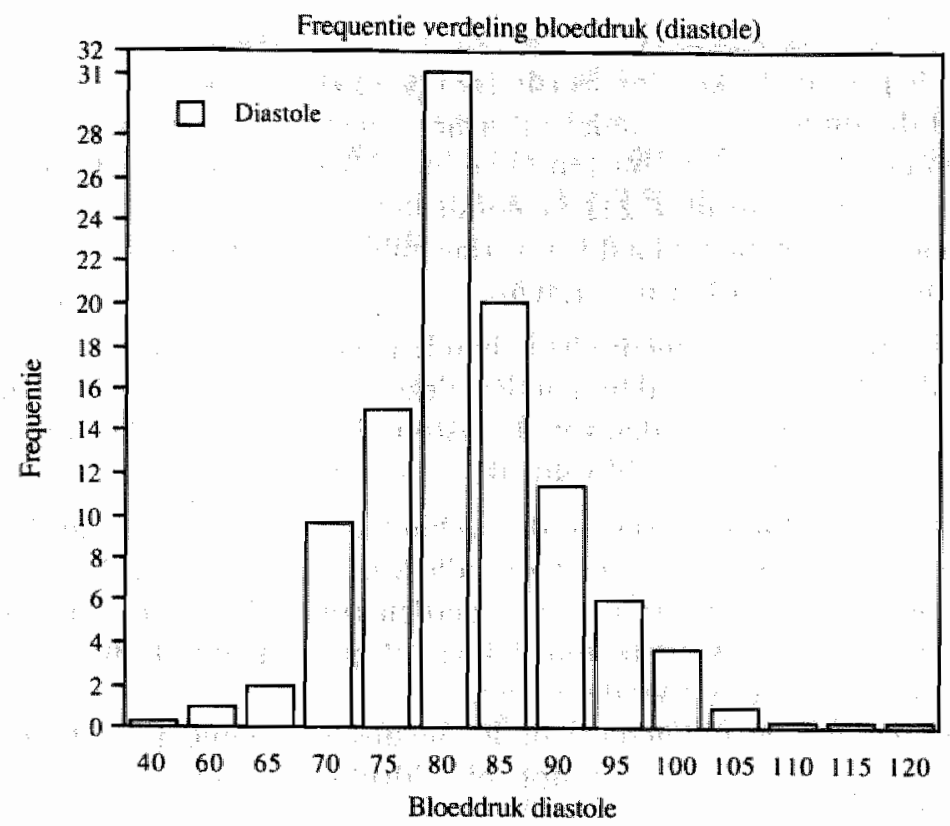

Frequentie verdeling bloeddruk

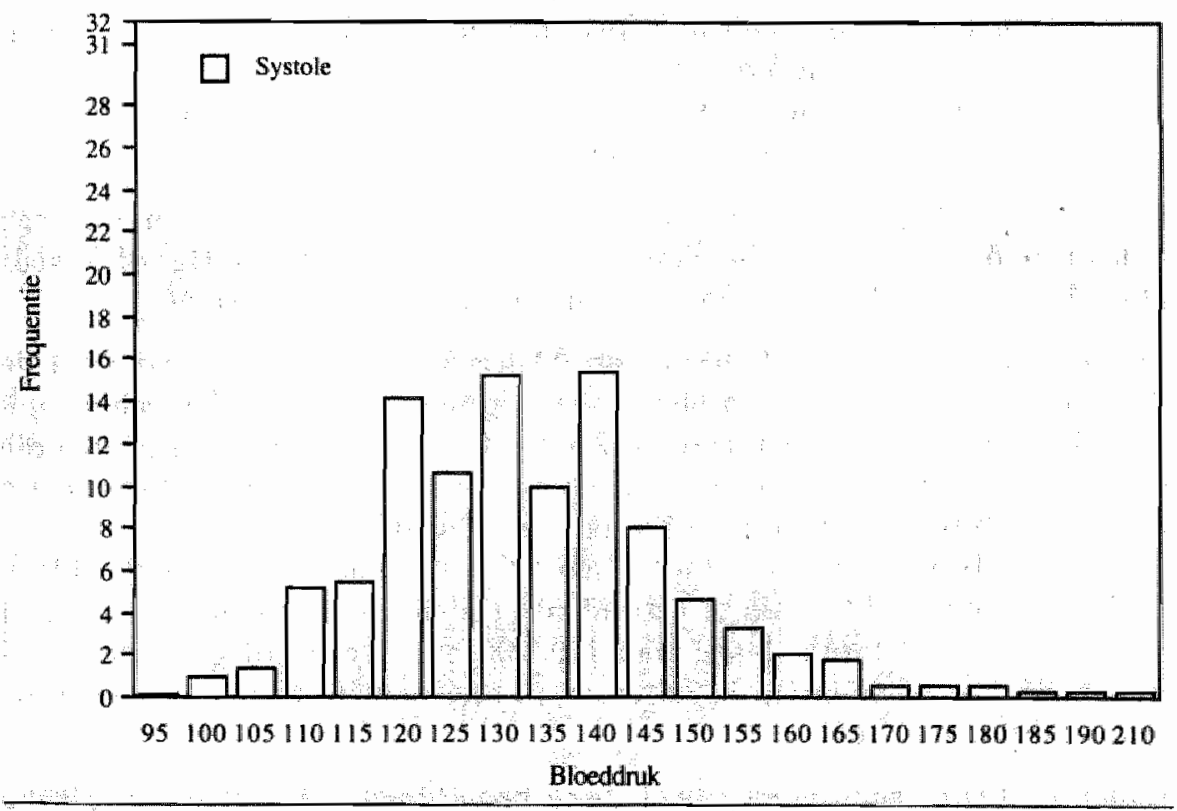


Als onderdeel van het psychologisch gedeelte van het onderzoek werd tevens gevraagd naar lichamelijke klachten en ziekten waaraan men momenteel lijdt. Op de vraag: 'Heeft $u$ hoge bloeddruk'?, antwoordden 116 mensen bevestigend.

Tijdens de periodieke keuring wordt door de respondenten ook een vragenlijst ingevuld die onder andere nader informeert naar cardiovasculaire klachten. Op de vraag: 'Is er bij u ooit een hoge bloeddruk vastgesteld'?, antwoordde 242 bevestigend. Van deze 242 respondenten zeggen er 61 dat ze momentel behandeld worden met bloeddrukverlagende middelen en 33 respondenten zeggen dieetvoorschriften te krijgen.

In veel gevallen zal deze medische behandeling effect sorteren en zal derhalve de bloeddruk lager zijn dan zonder deze voorschriften. Het is dus niet mogelijk de continue waarden van de systolische en diastolische bloeddruk als indelingscriteria voor hoge bloeddruk te hanteren.

De volgende indelingscriteria werden gehanteerd conform die van het BGDonderzoek, richtlijnen van de Gezondheidsraad (1983) en Van der Feen (1977). In de groep 'hypertensieven' werden respondenten opgenomen met: 1. een systolische druk $\geq 160 \mathrm{~mm} \mathrm{Hg} \mathrm{en/of} \mathrm{een} \mathrm{diastolisch} \mathrm{druk} \geq 100 \mathrm{~mm}$ $\mathrm{Hg}$ tijdens eerste en de tweede meting,

2 . respondenten die momenteel onder medische behandeling staan wegens verhoogde bloeddruk en hiervoor bloeddrukverlagende middelen krijgen voorgeschreven.

In de groep 'normotensieven' werden opgenomen:

1. respondenten die op géén van de twee bloeddrukmetingen een waarde laten registreren boven $160 / 100 \mathrm{~mm} \mathrm{Hg}$,

2. respondenten die géén van de twee schriftelijke vragen naar het vóórkomen van hypertensie positief beantwoordden.

In de groep 'hypertensieven' zijn dus respondenten opgenomen met een bloeddruk die hoger is dan het gestelde criterium $(160 / 100 \mathrm{~mm} \mathrm{Hg})$ of wegens bloeddrukverlagende middelen onder medische behandeling staan.

Personen die maar ten dele beantwoordden aan de gestelde criteria voor de 'hypertensieve groep' werden hierin niet opgenomen. Zij werden echter ook uitgesloten voor de referentiegroep. Zo werden respondenten uitgesloten die bijvoorbeeld wel één van de twee vragen naar het voorkomen van hypertensie positief beantwoordden en men een normale bloeddruk liet meten tijjdens de keuring. Zelfs als men beide vragen naar het voorkomen van hoge bloeddruk positief beantwoordde maar er desondanks tijdens de medische keuring toch geen te hoge bloeddruk (hoger dan $160 / 100 \mathrm{~mm} \mathrm{Hg}$ ) werd gevonden, dan werd men niet in de groep hypertensieven opgenomen maar ook niet in de groep normotensieven.

Indien de betreffende vragen over de te hoge bloeddruk niet of onvolledig 
waren ingevuld dan werd men niet verder opgenomen in de beide onderzoeksgroepen. Eveneens werden respondenten uitgesloten die meer dan $20 \%$ van de medische of psychologische gegevens onvolledig hadden ingevuld.

Op grond van bovenstaande criteria zijn 127 'hypertensieven' en 770 'normotensieven' opgenomen in het onderzoek.

Hieronder volgt een overzicht van de respondenten die aan het onderzoek hebben meegedaan en van de hyper-en normotensieven die uiteindelijk in de onderzoeksgroepen zijn opgenomen.

Tabel 6.1. Overzicht van de samenstelling wan de onderzoeksgroep

wragemlijst in ontvangst genomen

wragenlijst geretoumeerd

niet opgenomen in het onderzoek:

- gantal vrouwen

- personen met hart- of nieraandoening

- niet classificeerbaar of uitgesloten wegens het slechts gedeeltelijk

woldoen aan de bovengestelde criteria

totaal aantal respondenten opgenomen

in het onderzoek:

- aantal 'Thypertensieven'

- aantal "normotensieven"
1619

1172

61

1.4

200

897

127

770

\subsubsection{PSYCHOSOCIALE VARIABELEN: BESCHRIJVING VAN DE MEETINSTRUMENTEN}

\subsubsection{LEVENSOMSTANDIGHEDEN (LOM)}

Deze lijst is door de auteur in samenwerking met Van de Willige speciaal voor dit onderzoek ontwikkeld. Het doel is om een gedetailleerd beeld te krijgen van de aard van de levensomstandigheden van elke respondent op het ogenblik van de invuldatum. Per deelgebied worden vragen over min of meer feitelijke gegevens alsmede over perceptie en evaluatie van een ervaren situatie gesteld.

De lijst bevat 161 items betreffende vragen naar woonomstandigheden, werkomstandigheden, relaties met partner, sociale steun van de netwerken familie, vrienden, buren en collega's. Verder gaat het om vragen naar de invulling van de vrije tijd, de financiële situatie en jeugdervaringen.

Verreweg de meeste vragen kunnen met ja/nee beantwoord worden. Enkele vragen worden beantwoord door aankruising op een 10-puntsschaal. Het betreft in dit geval vragen naar de mate van tevredenheid van de woonsituatie, werksituatie, partnerrelatie en de financiële situatie. 
Data-reductie is toegepast via factor-analyse (Varimax). Uiteindelijk bleek een analyse, waarbij 9 factoren werden verkregen het beste te interpreteren. Ook kwamen de factoren goed overeen met de indeling van levensomstandigheden zoals die a priori was vastgesteld. Alleen items met een factorscore die boven $.40 \mathrm{lag}$, werden opgenomen in de betreffende factor. Items die op meer factoren hoog laadden, werden niet opgenomen.

De aldus verkregen factoren staan hieronder genoemd onder vermelding van de betrouwbaarheidsmaten (Cronbach alpha).

Tabel 6.2. Factoren van de lijst Levensomstandigheden (LOM) en de interne consistentie (Cronbach alpha).

\begin{tabular}{ll}
$\begin{array}{ll}\text { Facroren, van de lijst } \\
\text { Levensomstandigheden }\end{array}$ & Bet \\
\hline - woondissatisfactie & .80 \\
- werkbelasing & .71 \\
- socialle steun van: & \\
- buren collega's en vrienden & .75 \\
- familie & .67 \\
- partnerrelatie & .78 \\
- jeugdervaring & .77 \\
- vrijetijdsbesteding & .55 \\
- problemen met kinderen & .67 \\
- financiële problemen & .79
\end{tabular}

De scores op de factoren zijn alswolgt te interpreteren:

- factor woondissatisfactie: een hoge score betekent een hoge mate van ontevredenheid met de woonsituatie

- factor werkbelasting: een hoge score betekent een hoge mate van ervaren belasting op het werk

- factor sociale steun: cen hoge score staat voor een hoge mate van ervaren steun

- factor partnerrelatie: een hoge score betekent een hogere mate van ontevredenheid met de partnerrelatie

- factor jeugdervaring: een hoge score staat voor een prettige jeugdervaring

- factor vrijetijdsbesteding: een hoge score betekent hoge mate van tevredenheid

- factor problemen met kínderen: een hoge score betekent veel problemen met de kinderen

- factor financiele problemen: een hoge score ștaat voor veel financiële problemen.

De factoren met de bijbehorende vragen van de lijst 'levensomstandigheden' (LOM) staan vermeld in bijlage $\mathrm{A}$.

\subsubsection{VRAGENLIJST RECENT MEEGEMAAKTE GEBEURTENISSEN (VRMG)}

Het uitgangspunt voor de 'Vragenlijst Recent Meegemaakte gebeurtenissen' (VRMG) was de 'Recent Life Change Questionnaire' (RLCQ) van Rahe (1978). Deze lijst hebben we vertaald en opgenomen in het BGD-onderzoek zoals beschreven in hoofdstuk 5 . 
Uit de analyse van de resultaten bleek dat de beantwoording van de lijst moeilijkheden opleverde. Het was omslachtig omdat men eerst alle meegemaakte gebeurtenissen moest aankruisen en deze vervolgens, na het lezen van een tweede instructie, van een zogenaamde aanpassingsscore moest voorzien. Ook het begrip aanpassingsscore bleek voor velen niet geheel duidelijk. Verder was op deze lijst dezelfde kritiek van toepassing als op de RLCQ: uit de aanpassingsscore kon niet afgeleid worden of een gebeurtenis als positief of negatief, dan wel als wenselijk of onwenselijk werd gewaardeerd. Daarnaast bestond er twijfel over de volledigheid van de lijst en leverde de korte formulering van de items moeilijkheden op bij de interpretatie van de scores. Om deze redenen besloten Van de Willige en de auteur een nieuwe lijst te construeren. Ter aanvulling van de item-pool werden enkele items van 'gebeurtenissen-lijsten' van Paykel e.a. (1971), Tennant en Andrews (1976) Sarason e.a. (1983) opgenomen. Eveneens werd geput uit de in Nederland toegepaste interview-methode van Ormel (1980). Aangezien gebeurtenisen die anderen overkomen, voor de respondent een aanzienlijke belasting met zich mee kunnen brengen, is een inventarisatie hiervan in de lijst opgenomen. Het betreft dan voornamelijk gebeurtenissen die familieleden hebben meegemaakt of personen uit de directe omgeving.

Voor de nieuwe vragenlijst werd een subjectieve scoringsmethode ontwikkeld, waarbij zowel met negatieve als positieve aspecten van een gebeurtenis rekening werd gehouden. In navolging van Ormel is gekozen voor een scoring van de mate van 'onplezierigheid' en 'plezierigheid'. Aan de respondenten wordt gevraagd om aan te geven welke van de in de lijst genoemde gebeurtenisen zij in de afgelopen 12 maanden hebben meegemaakt. Bij de aangekruiste items dient men vervolgens zowel de ondervonden plezierigheid als de onplezierigheid te scoren op een vijf-puntsschaal.

We hebben ons beperkt tot gebeurtenissen die zich in het jaar voorafgaande aan de afname hebben voorgedaan. Bij een langere periode is de kans op vergeten onevenredig groot en kan er een verschuiving optreden van de mate van subjectief ervaren (on)plezierigheid (Horowitz e.a., 1974).

In de uiteindelijke lijst zijn 59 gebeurtenissen opgenomen, die met onderverdelingen tezamen 115 verschillende items omvatten. De gebeurtenissen zijn gerubriceerd in vijf categorieën, te weten:

'gezondheid', 'werk', 'familie, vrienden of relaties', 'persoonlijke omstandigheden' en 'financiën'.

Voor psychometrische gegevens verwijzen we naar Van de Willige, Schreurs, Tellegen en Zwart (1985). De vragenlijst en enkele gegevens zijn opgenomen als bijlage $B$ en $C$. 


\subsubsection{ZELF BEOORDELINGS VRAGENLIJST (ZBV): het meten van angst}

Voor het meten van angst is gebruik gemaakt van de Zelf Beoordelings Vragenlijst (ZBV). Het is een Nederlandse bewerking van de Spielberger State-Trait Anxiety Inventory (Van der Ploeg, Defares en Spielberger, 1980). In dit onderzoek is alleen gebruik gemaakt van de schaal 'angstdispositie'. Hieronder wordt verstaan relatief stabiele individuele verschillen in angstgeneigdheìd'.

Voor gedetailleerde psychometrische gegevens verwijzen we naar de handleiding van de vragenlijst (Van der Ploeg e.a., 1980).

\subsubsection{SCHAAL VOOR INTERPERSOONLIJK GEDRAG (SIG): het meten van assertiviteit}

In het eerder beschreven onderzoek bij de BGD is gebruik gemaakt van de Leidse Lijst voor Sociale Situaties (LLSS) om de mate van assertief gedrag te meten (De Groot, Walburg, 1977).

De lijst heeft verschillende experimentele versies gekend, waarbij telkens eenzelfde factorstructuur werd aangetroffen. In de laatste versie die 50 items bevat en waarbij de lijst een nieuwe naam kreeg namelijk 'Schaal voor Interpersoonlijk Gedrag' (SIG), komt men echter tot een nieuwe factorindeling van 4 subschalen. De SIG kent in zijn definitieve vorm 4 schalen: schaal 1: Het uiten van negatieve gevoelens: kritiek geven, weigeren (NEG); schaal 2: Het uiten van onzekerheid en eigen ontoereikendheid: kritiek ontvangen, aandacht en hulp vragen (ONZ);

schaal 3: Jezelf kenbaar maken: kontakt leggen, mening geven (KEN);

schaal 4: Het uiten van positieve gevoelens: komplimenten, waardering geven en ontvangen (POS);

totaalschaal: $\mathrm{NEG}+\mathrm{ONZ}+\mathrm{KEN}+\mathrm{POS}+\mathrm{UIT}$ :

De schalen 1 (NEG) en 3 (KEN) meten sociaal gedrag dat Arrindel e.a.(1984) omschrijven als klassieke assertiviteit. De schalen 2 (ONZ) en 4 (POS) hebben te maken met het laten zien van gevoelens van onzekerheid en positieve gevoelens.

De items van de SIG moeten twee keer gescoord worden de eerste maal voor spanning en de tweede maal voor frequentie van voorkomen. De SIG verschilt niet wezenlijk van de eerdere versie van de LLSS zoals we die in het onderzoek bij de BGD (zie H5) hebben opgenomen. Aangezien de SIG echter verder is uitgewerkt en er een handleiding met psychometrische gegevens voorhanden is (zie Arrindel, de Groot, Walburg, 1984) hebben we besloten deze gewijzigde versie in het vragenlijstpakket op te nemen.

In ons onderzoek maken we alleen gebruik van de twee totaalscores: de totaalscore op de 'Spannings-schaal' (SIGSP) en de totaalscore op de 'Frequentie-schaal' (SIGFR). 


\subsubsection{INTERNE-EXTERNE 'LOCUS OF CONTROL' (I-E):} het meten van beheersingsorientatie

In het eerste onderzoek hebben we gebruik gemaakt van de vertaalde versie van de Rotter I-E schaal. Ook in dit onderzoek wordt gebruik gemaakt van deze lijst. Voor verdere gegevens verwijzen we derhalve naar 5.1.3.5 en naar Rodenburg (1974).

\subsubsection{JENKINS ACTIVITY SURVEY (JAS):}

het meten van het type $\mathrm{A}$ gedragspatioon

Evenals in het vorige onderzoek wordt gebruik gemaakt van de vertaalde versie van de JAS (Appels, 1979). Voor verdere gegevens verwijzen we naar par. 5.1.3.6.

In 1985 is door Appels een handleiding uitgegeven van een verkorte versie van de JAS (Appels, 1985). Deze bevat 24 items.

We hebben de scores op de uitgebreide 36 item-lijst gecorreleerd met de korte versie hetgeen resulteerde in een Pearson $r$ van 92. In het onderhavige onderzoek worden de resultaten besproken met betrekking tot de uitgebreide versie.

\subsubsection{ZELF ANALYSE VRAGENLIJST (ZAV):}

het meten van boosheids-dispositie

De zelfanalyse vragenlijst (ZAV) is een Nederlandse vertaling van de Spielberger State Trait Anger Scale (Van der Ploeg e.a., 1982), De ZAV bestaat uit twee afzonderlijke zelfrapportage vragenlijsten waarmee een tweetal boosheid-concepten kan worden gemeten: toestandsboosheid ("state anger') en boosheidsdispositie ('trait anger'). Met toestandsboosheid bedoelen de auteurs 'de voorbijgaande emotionele conditie van het individu gekenmerkt door subjectief ervaren gevoelens van spanning, boosheid, kwaadheid en woede, irritatie, ergernis, opvliegendheid en driftigheid plus activiteit van het autonome zenuwstelsel'. Boosheidsdispositie verwijst naar relatief stabiele individuele verschillen in de tendenties om boosheid of woede als toestand te ervaren, $d, w . z$. naar verschillen tussen mensen in hun dispositie om een veellheid aan situaties te ervaren als frustrerend en die kwaadheid of ergermis uitlokken. In ons onderzoek zullen we alleen de boosheidsdispositie meten.

De ZAV boosheidsdispositie bestaat uit 10 items betreffende uitspraken hoe men zich in het algemeen voelt.

Personen met een grote mate van boosheidsdispositie zijn meer geneigd om toestandsboosheid te ervaren. $\mathrm{Zij}$ ervaren ook meer intense verhogingen van de toestandsboosheid wanneer frustrerende of hinderende, ergernis uitlokkende situaties zich voordoen. 
Voor gedetailleerde gegevens verwijzen we naar de handleiding van de ZAV (Van der Ploeg e.a., 1982).

\subsubsection{DE UTRECHTSE COPINGLIJST (UCL): het meten van coping}

De veronderstelling dat de wijze van omgaan met problemen en bedreigende gebeurtenissen van grote invloed is op het psychologisch, fysiek en sociaal welzijin is in verscheidene onderzoeken bevestigd (zie Kleber, 1986). Zoals besproken in hoofdstuk 3 en 4 speelt coping eveneens een belangrijke rol met betrekking tot de ontwikkeling en instandhouding van essentiële hypertensie.

Aangezien binnen het cognitief-leertheoretisch kader geen geschikte vragenlijst beschikbaar was, hebben we een dergelijk instrument zelf ontwikkeld.

Copinggedrag wordt gedefinieerd als de manier waarop iemand zowel gedragsmatig cognitief als emotioneel op aanpassingvereisende omstandigheden reageert (zie voor een uitvoerige beschrijving hoofdstuk 3 en Schreurs e.a., 1987)

Als basis voor de ontwikkeling van een Nederlandstalige copinglijst werd de classificatie van copinggedrag van Westbrook (1979) genomen. De reden hiervoor was op de eerste plaats de geschikte lengte van de lijst, namelijk 30 korte items. Bovendien ligt in deze lijst de nadruk op het gedragsmatig aspekt van coping.

Westbrook stelde aan de hand van de literatuur een lijst samen van 30 items. Via een multidimensionele analyse kwam zij tot 6 clusters van strategieèn;

1. actie/confrontatie,

2. vermijding,

3. zoeken van sociale steun,

4. optimisme,

5. fatalisme en

6. controle over de situatie.

De items werden vertaald en de lijst werd in het kader van een onderzoek naar de rol van psychosociale faktoren bij essentiële hypertensie bij de Bedrijfsgeneeskundige Dienst Utrecht afgenomen bij 105 mannen (Schreurs e.a., 1984).

Bij beschouwing van de frequentieverdelingen bleek dat van diverse items de voorkeur voor een van de beide antwoordcategorieen zo hoog was (van 10 items viel minstens $90 \%$ van de antwoorden in een categorie), dat de discriminatieve waarde van deze items als zeer laag beschouwd kan worden. Bovendien bleek dat bij een analyse van de correlaties tussen de items slechts 3 van de 6 clusters van Westbrook geïdentificeerd konden worden. Om deze redenen werd besloten de lijst in deze vorm, niet langer te gebruiken. 
Aan de hand van verder literatuuronderzoek werd een indeling in een drietal categorieën van copinggedrag geformuleerd:

a. Coping-gedrag dat gericht is op het aanpakken van de situatie (confrontatie).

b. Copinggedrag dat gericht is op het beïnloeden van de perceptie en evaluatie van problemen en gebeurtenissen. Hierbij wordt de probleemsiuatie niet direct aangepakt of veranderd maar indirect via cognitieve herstructurering.

c. Copinggedrag dat in eerste instantie gericht is op de reduktie van ervaren lichamelijk en psychische spanning. Dit kan via het gebruik van tranquillizers, consumptie van alcohol, drugs en sigaretten en dergelijke. Dit gedrag wordt palliatief genoemd.

Er werden nieuwe items toegevoegd, afkomstig uit een pool van items van diverse 'copinglijsten' zoals van Folkman en Lazarus, (1980), Robbins en Tanck (1978) en Plutchik (1979). Uiteindelijk werden 49 items in de nieuwe lijst opgenomen.

Deze yersie werd uitgetest bij 225 studenten psychologie en medicijnen. Op deze gegevens werd een factoranalyse uitgevoerd volgens de Hoofdassenmethode (factoren met een eigenwaarde groter 1.0 werden verder geroteerd met de Varimaxmethode). Dit leverde tien factoren op die redelijk tot goed te interpreteren bleken en die in grote lijnen overeenkwamen met de a priori classificatie van copinggedrag. Vervolgens werden schalen gevormd door van elke factor die items op te nemen die een lading hadden van boven .40 en die tevens niet op andere factoren hoog laadden. De aldus gevormde schalen bleken redelijk tot goed betrouwbaar (Cronbach's alpha variëerden van .70 tot .82 ). Deze resultaten gaven aanleiding om op de ingeslagen weg door te gaan en deze versie van de lijst te verbeteren. Zo was het noodzakelijk om de items die op geen enkele factor een hoge lading hadden, of op verscheidene factoren hoog laadden, inhoudelijk aan te passen of in het geheel te verwijderen. Schalen die minder dan 3 items bevatten werden uitgebreid danwel geheel verwijderd. Het totale aantal items kwam hiermee op 47 en de lijst werd de 'Utrechtse Coping Lijst' (UCL) genoemd (Schreurs e.a., 1984).

Deze versie van de UCL werd aan ongeveer 600 personeelsleden van de Nederlandse Spoorwegen voorgelegd. De Jeeftijd variëerde van 23 tot 55 jaar met een gemiddelde van 42 jaar $(s . d .=10.9)$. Van de factoranalyse bleek de analyse waarin werd geroteerd met 7 factoren, het best te interpreteren en ook het meest aan te sluiten op de a priori indleling. De volgende subschalen werden gedefinieerd:

Schaal A - aanpakken, problemen proberen op te lossen Omschrijving: de situatie rustig van alle kanten bekijken, de zaken op een rijtje zetten; doelgericht en met vertrouwen te werk gaan om het probleem op te lossen. 
Schaal $\mathbb{P}$ - palliatieve reaktie

Omschrijving: afleiding zoeken en zich met andere dingen bezighouden om niet aan het probleem te hoeven denken: proberen zich wat prettiger te voelen door te roken, te drinken of zich wat te ontspannen.

Schaal V - vermijden, afwachten

Omschrijving: de zaak op zijn beloop laten, de situatie uit de weg gaan of afwachten wat er gaat gebeuren.

Schaal S - sociale steun zoeken

Omschrijving: het zoeken van troost en begrip bij anderen; zorgen aan iemand vertellen of hulp vragen.

\section{Schaal D - depressief reaktiepatroon}

Omschrijving: zich volledig door de problemen en de situatie in beslag laten nemen, de zaak somber inzien, zich piekerend in zichzelf terugtrekken, niet in staat om iets aan de situatie te doen; piekeren over het verleden.

Schaal E - expressie van emoties/boosheid

Omschrijving: het laten blijken van ergernis of kwaadheid: spanningen afreageren.

Schaal G - geruststellende en troostende gedachten

Omschrijving: zichzelf geruststellen met de gedachte dat na regen zonneschijn komt, dat anderen het ook wel eens moeilijk hebben of dat er nog wel ergere dingen gebeuren; jezelf moed inspreken.

\section{INTERCORRELATIES}

Inzicht in de relaties tussen de subschalen onderling kan leiden tot een betere interpretatie van de inhoud van elke schaal. In tabel 6.3 staan de intercorrelaties vermeld, berekend met de Pearson-correlatie. Als data zijn de testscores van 1200 NS-personeelsleden gebruikt.

Tabel 6.3. Intercorrelaties yan de UCL-schalen

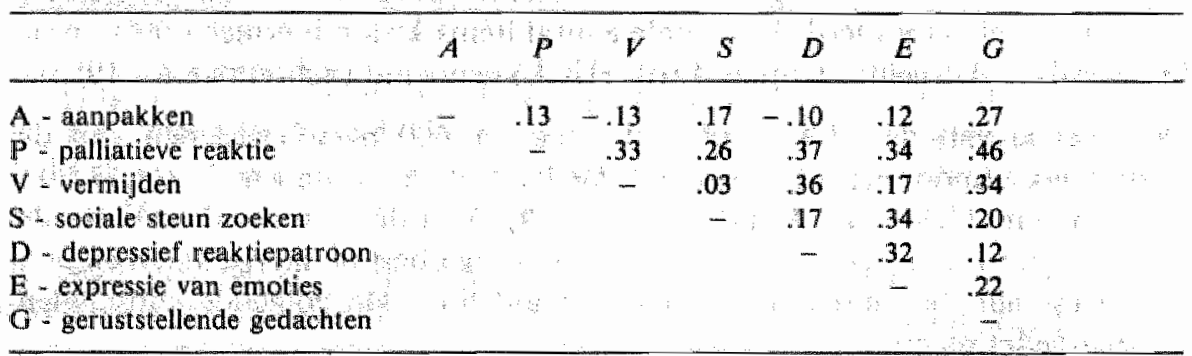

Opvallend zijn de iets hogere correlaties van de schaal $P$ (palliatieve reactie) met bijna alle andere schalen, behalve met de eerste (A, actief aanpakken). In al deze schalen lijkt een element te zitten van het ontwijken van het probleem, en het geven van prioriteit aan het reguleren van de opgeroepen spanning. Een 
andere opvallende correlatie, namelijk die tussen vermijden, afwachten (V) en depressieve reactie (D) zal ook geen verbazing wekken. In beide manieren van coping zit een duidelijk element van inadequatie, een laag zelfbeeld, vanwege de hoge correlaties met de betreffende subschaal van de NPV en de ZBVangstdispositie ( Van der Ploeg, 1982 en Bleijenberg, p.c.). Een derde groep correlaties die opvalt, die tussen de E-schaal enerzijds en de $P, S$, en $D$-schaal anderzijds. Dat wil zeggen dat 'uiten van gevoelens van $k$ waadheid' verband houdt met een hogere score op de schaal palliatieve reacties en op de schaal 'zoeken van sociale steun' en de schaal 'depressieve reacties'.

\section{BETROUWBAARHEID EN VALIDITEIT}

De afgelopen drie jaar is er door verschillende onderzoekers ervaring opgedaan met de UCL. De lijst werd in veel studies opgenomen als onderdeel van een uitgebreide batterij vragenlijsten. De resultaten die betrekking hebben op psychometrische eigenschappen van de lijst zoals betrouwbaarheid en validiteit staan vermeld in de handleiding van de UCL (Schreurs e.a.,1987). We zullen hier kort de belangrijkste conclusies samenvatten.

De schalen van de LCL zijn vergeleken met:

Nederlandse Persoonlijkheids Vragenlijst (Luteijn e.a. 1975): deze meet inadekwatie, rigiditeit, verongelijktheid, dominantie, zelfgenoegzaamheid en zelfwaardering;

Locus of control test (Andriessen,1972): deze meet de mate van beheersingsoriëntatie;

Zung-depressie schaal (Zung, 1965): deze meet de mate van depressiviteit;

Prestatie-Motivatie Test (Hermans, 1976): deze meet negatieve en positieve faalangst;

Vragenlijst Ervaren Gezondheid (Dirken, 1967);

Zelf Analyse Vragenlijst (Van der Ploeg e.a., 1982): deze meet de boosheidsdipositie en de toestandsboosheid;

Zelf Beoordelings Yragenlijst: deze meet de angst-dispositie en de toestandsangst;

Jenkins Activity Survey (Appels e.a.,1979): deze meet het type-Agedragspatroon;

Ways of Coping van de onderzoeksgroep rond Lazarus (zie Folkman en Lazarus, 1980): deze meet zowel probleem-gerichte coping alswel emotiegerichte coping.

In onderstaande tabel staan een aantal substantiële Pearson correlaties (boven .20 en alle significant) tussen deze vragenlijsten en de schalen van de UCL. Het betreft een samenvatting van resultaten van onafhankelijk van elkaar uitgevoerde onderzoeken.

Schaal A (aanpakken) correleert goed met de subschaal 'probleem-gerichtecoping', met de lijst 'habituele actie-bereidheid', met 'interne beheersingsoriëntatie, met 'Inadekwatie' en met de Prestatie-Motivatie test. 
Tabel 6.4. Pearsion correlaties tussen verschillende psychologische vragenijisten en de UCLschalen*.

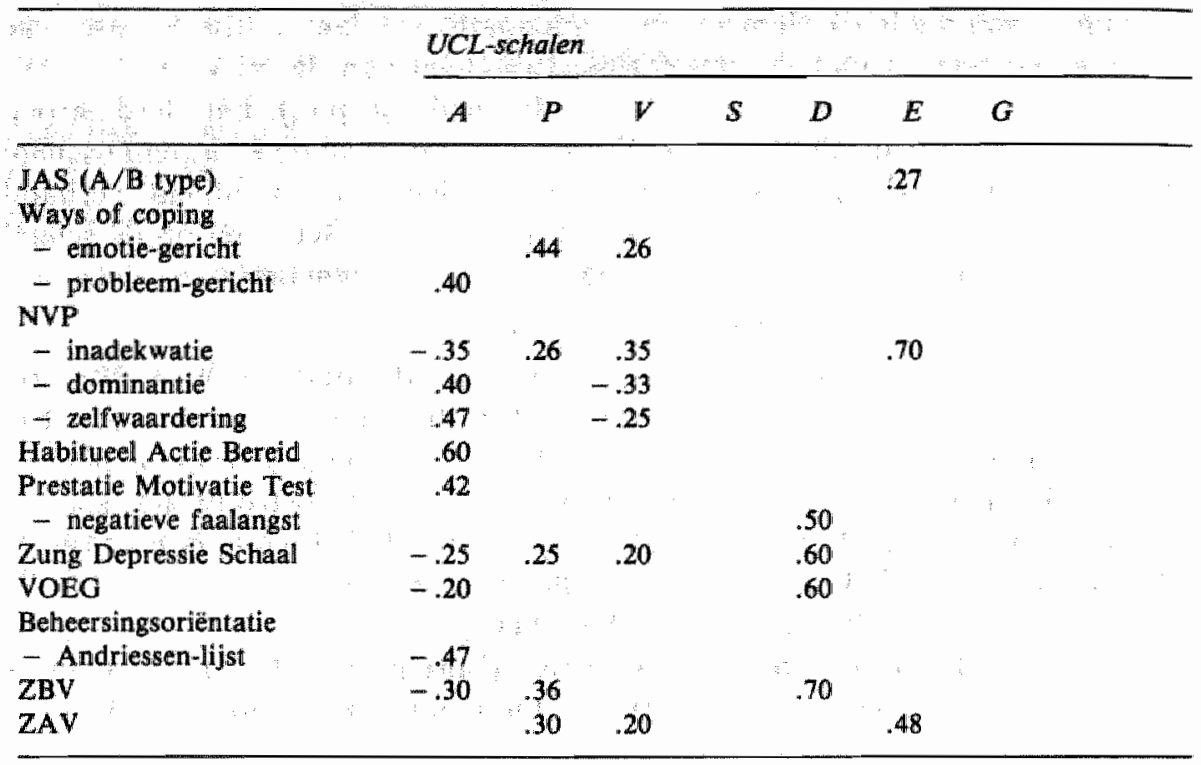

* weergegeven zijn uitsluitend correlaties hoger dan 20

* alle vermelde correlaties zijn significant op 5\%-niveau

* UCL-schalen: $A=$ aanpakken, $\mathbb{P}=$ palliatieven, $V=$ vermijden / afwachten, $S=$ sociale steun zoeken, $\mathrm{D}=$ depressief reactiepatroon, $\mathrm{E}=$ uiten van emoties, $\mathrm{G}=$ geruststellende gedachten.

Er bestaat verder een positief verband met "gevoelens van zelfwaardering". Voorzichtigheid bij de interpretatie van deze schaal is geboden vanwege mogelijke invloeden van de factor sociale wenselijkheid.

Schaal P (palliatieve reacties) correleert goed met de subschaal 'emotiegerichte-coping". Verder is er een verband met angst- en boosheidsdispositie, met gevoelens van insufficiëntie en met de depressie-schaal.

Schaal V (vermijden en afwachen) correleert zwak met "emotie-gerichtecoping', 'inadekwatie', 'dominantie' en angstdispositie.

Schaal S (sociale steun zoeken) is nog niet uitgebreid gecorreleerd met een gelijksoortige lijst. Wel is duidelijk dat de factor slechts ten dele overeenkomt met het begrip 'social support' zoals gedefinieerd door Cobb (1976).

Schaal D (depressief reactiepatroon) heeft duidelijke overeenkomsten met 'inadekwatie' en met angstdispositie. Verder bestaat er een goede correlatie met de lijst VOEG (ervaren gezondheid), met de Zung-depressie-lijst en met negatieve faalangst.

Schaal E (emoties uiten) correleert goed met de boosheids-dispositie en er is een zwakker verband met het type-Agedrag. 
Schaal G (geruststellende gedachten) correleert zeer laag met alle hierboven genoemde vragenlijsten.

Tenslotte nog een opmerking over de betrouwbaarheid van de schalen. De interne correlatie berekend met de Cronbach alpha over ongeveer 1200 respondenten van de Nederlandse Spoorwegen varieert van .64 tot .82. Ook in het onderzoek van Van der Ploeg (1982) worden deze alpha's teruggevonden.

Test-hertest gegevens met een interval van 6 weken zijn eveneens uit deze studie afkomstig. Voor de schalen bedraagt de correlatie respectievelijk . .79, $.52, .64, .74, .69, .70, .61$. Ook de gegevens afkomstig uit het astma-project (Vromans, persoonlijke communicatie) waarbij ongeveer 200 astma-patiënten de UCL na een jaar nogmaals invullen, wijzen op een redelijk consistent en vergelijkbaar beeld. Voor verdere psychometrische gegevens verwijzen we naar de handleiding wan de UCL (Schreurs e.a., 1987) en Ormel en Sanderman (in voorbereiding).

De lijst is opgenomen als bijlage $\mathrm{D}$.

\subsubsection{DEFENSIE MECHANISMEN LIJST (DMI):}

het meten van defensiemechanismen

In het eerder beschreven onderzoek bij de BGD is gebruik gemaakt van de integrale en lange versie van de 'Defense Mechanism Inventory' (DMI) (zie 5.1.3.8).

Deze versie bevat telkens voor ieder thema (autoriteit, onafhankelijkheid, mannelijkheid of vrouwelijkheid, competitie en situationeel bepaalde conflicten) twee situatieschetsen. Omdat de gehele D.M.I. voor het N.S.onderzoek te uitgebreid werd bevonden, zijn slechts 5 van de 10 situaties opgenomen. In de verkorte versie is telkens die variant gekozen die in het BGD-onderzoek de hoogste interne consistentie bleek te hebben (' $x$ '-versie). Op de gegevens van de scores op de verkorte versie van ongeveer 900 personeelsleden N.S. is wederom de betrouwbaarheid van de schalen nagegaan. De resultaten hiervan staan in tabel 6.5 .

Tabell 6,5. Betrouw baarheidscoefficiènten (Cronbach alfa) van de D.M.L-schalen van de verkorte versie ( $\mathrm{x}$-versile)

$\begin{array}{ll}\text { B.O. D. onderzoek } & \text { N.S. -onderzoek } \\ x \text {-versie } & x \text {-versie } \\ 93 \text { mannen } & 901 \text { mannen }\end{array}$

DMII-schalen

- Turning Against Object (TAO)

- Projectie (PRO)

- Principalisatie (PRN)

- Turning Against Self (TAS)

- Reversal (REV)

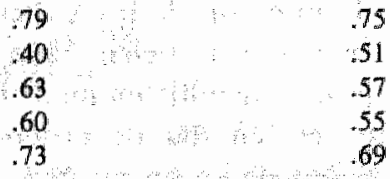


In de tabel zijn ter vergelijking de betrouwbaarheden van de DMI-versie van het BGD-onderzoek opgenomen: De X-versie staat dus voor de variant met de hoogste betrouwbaarheid. Het lijkt erop dat de 'halve', D.M.I. niet veel minder betrouwbaar uitvalt. De Cronbach alfa's zijn overigens nagenoeg identiek aan die welke de auteurs van de lijst rapporteerden (Gleser en Ihilevich, 1969).

\section{INTERCORRELATIES VAN DE SCHALEN}

De correlaties tussen de schalen laten hetzelfde beeld zien als dat van Gleser \& Ihilevich (1969): een fel kontrast tussen enerzijds TAO en PRO en anderzijds PRN en REV. De gegevens vertonen een goede gelijkenis met de resultaten die we hebben verkregen met de volledige lijst, zoals gebruikt in het BGD-onderzoek.

Tabel 6.6. Intercorrelaties DMI-schalen (verkorte of wel $x$-versie)

\begin{tabular}{lcrrrr}
\hline variabele & TAO & PRO & PRN & TAS & REV \\
\hline TAO & - & .36 & -.57 & -.53 & -.64 \\
PRO & & - & -.44 & -.46 & -.54 \\
PRN & & & - & .05 & .19 \\
TAS & & & & - & .18 \\
REV & & & & & - \\
\hline
\end{tabular}

De tegenstellingen tussen de verschillende factoren zoals die in de intercorrelaties waarneembaar zijn, komen terug in de resultaten van een factoranallyse (Varimax) die is uitgevoerd over ongeveer 900 respondenten. In dit onderzoek maken we gebruik van de 5 originele schalen en van twee samengestelde variabelen, namelijk TAO/PRO en de composietschaal. De schaal TAO/PRO wordt samengesteld door optelling van de scores op de schalen TAO en $\mathrm{PRO}$, Deze score kan inhoudelijk worden opgevat als 'acting out gedrag" . De composietschaal is opgebouwd uit de score op TAO en op PRO minus de score op PRN en op REV. Deze score kan worden opgevat als maat voor externalisatie versus internalisatie. Externalisatie is de expressie van agressie en onder internalisatie wordt verstaan defensies die agressie naar buiten inhiberen (juni, 1982).

De vragenlijst is opgenomen als bijlage $\mathrm{E}$.

\subsubsection{RELATIE LEEFTIJD EN PSYCHOSOCIALE VARIABELEN}

Alvorens we naar de intercorrelaties kijken betreffende de in het onderzoek toegepaste psychosociale variabelen gaan we na in hoeverre de variabele leeftijd de scores op de vragenlijsten mede bepaalt. Dit gegeven kan van extra belang zijn, gezien het feit dat de groep hypertensieven in dit onderzoek significant ouder is dan de groep normotensieven. 
In onderstaande tabel staan de verschillende Pearson correlaties tussen leeftijd met respectievelijk de persoonlijkheidskenmerken, aantal recent meegemaakte gebeurtenissen (VRMG) en de factoren van de Levensomstandigheden-lijst.

Tabel 6.7. Pearson correlaties woor de variabele leefijd met de persoontikheidskewmerken, het aantal recent meegemaakte gebeurtenissen en de factoren wan de Levensomstandigheden-lust.

\begin{tabular}{|c|c|c|c|c|}
\hline & & leefijid & & \\
\hline ZBV (angst) & & $.08 * *$ & VRMG (gebeurtenissen) & $-.21 * * *$ \\
\hline I-E (beheersing) & & .01 & LOM (omstandigheden) & \\
\hline JAS (type A) & $\because$ & $.11^{* * *}$ & - Noononteviedenhejd & $-13^{* * *}$ \\
\hline SIGSP (spanning) & & $.19^{* * *}$ & - sociale steun & 3 \\
\hline SIGFR(frequentie) & & $-.09 *$ & -buren & -.03 \\
\hline ZAV (boosheid) & & $.14 * * *$ & - collega"s &,$- 09 * *$ \\
\hline UCL (coping) & & & - familie & $\therefore-20^{* * *}$ \\
\hline - aanpakken & & $-.12 * * *$ & - vrienden & $\because-.16 * *$ \\
\hline - palliatieven & & .03 & - werkbelasting & $-13^{* * * *}$ \\
\hline - vermijden & & .05 & - partnerrelatie & $-.07^{*}$ \\
\hline - sociale steun & & $-.13^{* * *}$ & - problemen met: & .05 \\
\hline - depressief & & $.06 *$ & kinderen & 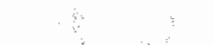 \\
\hline - emoties & & -.02 & - vrije tijd & .05 \\
\hline - geruststellen & & $.11 * * *$ & - financiële problemen & $-.13^{* * *}$ \\
\hline DMI & & & - jeugdervaring & .01 \\
\hline - TAO & & $-.15 * * *$ & & \\
\hline - PRO & & .02 & & \\
\hline - PRN & & -.06 & 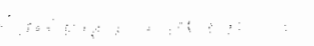 & $\because:$ \\
\hline - TAS & & $.11^{* *}$ & $\therefore: 18$ & $\therefore$ \\
\hline - REV & & $.15^{* *}$ & & \\
\hline - TAO/PRO & & $-20 * * * \quad$ & & \\
\hline - Composietschaal & & $-09^{* *}$ & 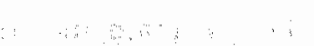 & \\
\hline
\end{tabular}

$* \mathrm{p}=.05^{* *} \quad \mathrm{p}=.01^{* * *} \mathrm{p}=.001$

In bovenstaande tabel vallen enkele cijfers op. De Pearson-correlaties betreffende de variabele leeftijd zijn in veel gevallen statistisch significant maar niet altijd even substantieel. Enkele relaties waarmee rekening moet worden gehouden, zijn: 'Spanning voor sociale situaties' $(r=19)$, de defensiemechanismen 'agressie naar buiten' $(r=-15)$ en 'omkering' $(r=.15)$, en verder met het aantal recent meegemaakte gebeurtenissen $(r=-21)$. De factor 'support van familie' van de Levensomstandigheden-lijst correleert met een $r$ van -.20 met de leeftijd. Bij de toetsing van de hypothesen van dit onderzoek moet dus in een aantal gevallen rekening gehouden worden met de variabele leeftijd.

\subsubsection{INTERCORRELATIES TUSSEN PSYCHOLOGISCHE VARIABELEN}

Om een beter inzicht te krijgen in de psyehologische begrippen die de verschillende vragenlijsten meten, bekijken we de onderlinge correlaties. In 
tabel 6.8. staan de intercorrelaties tussen alle psychologische variabelen vermeld.

Tabel 6.8. Intercorrelaties wan de psychologische variabelen, witgedrukt in Pearson r's.

\begin{tabular}{|c|c|c|c|c|c|c|c|}
\hline & $Z B W$ & $I-E$ & $J A S$ & SIGSP & SIGFR & $Z A V$ & $V R M G$ \\
\hline \multicolumn{8}{|l|}{ COPING } \\
\hline - aanpakken & $-.21 *$ & $-.18^{*}$ & $.18 * *$ & $-.18 *$ & $.27^{* *}$ & $-.11 * *$ & $.15 * *$ \\
\hline - palliatieven & $34^{* *}$ & $.07 *$ & $.20 * *$ & $.18^{-*}$ & $.15^{* * *}$ & $.28 * *$ & $.18 * *$ \\
\hline - vermijden & $.20 *$ & $.18^{* *}$ & $=02$ & $.32 *$ & -.04 & $.21 *$ & .02 \\
\hline - sociale steun zoeke & en $.09 \%$ & $-.07 *$ & $.15 *$ & .03 & $.20^{* * *}$ & $.16^{*}$ & $.15 * *$ \\
\hline - depressief & $67^{* * *}$ & $.16^{* * *}$ & $.28 * *$ & $36 * *$ & -.04 & $.42 *$ & $.17 * *$ \\
\hline - uiten emoties & $.29 * *$ & $.06^{*}$ & $.27 * *$ & $.19^{* *}$ & $.12^{* *}$ & $.47 *$ & $.13^{* *}$ \\
\hline \multicolumn{8}{|l|}{ - gerustellende } \\
\hline gedachten & .05 & $.09 * *$ & $10^{* * *}$ & $.15^{* *}$ & $.17 * *$ & $.13^{* *}$ & $.07 * *$ \\
\hline ZBV (angst) & $r$ & $.21^{* * *}$ & $.37 * *$ & $.44^{* *}$ & $-.08^{* *}$ & $.53 * *$ & .11 ** \\
\hline IE (beheersing) & & $:$ & -.05 & $.18 * *$ & $-.10^{* *}$ & $.18 * *$ & -.02 \\
\hline JAS (A-type) & & & & $.16^{* *}$ & $.08^{* * *}$ & $.47^{* *}$ & $\therefore 12 *$ \\
\hline SIGSP (sociale spanni & ing) & & & & $-.09^{* *}$ & $.37 * *$ & .02 \\
\hline SIGFR (frequentie) & & & & & & .02 & $.12^{* *}$ \\
\hline ZAV (boosheid) & & & & & & & $.07^{*}$ \\
\hline
\end{tabular}

$* p<0.5 * p<0.1$

Bij de bespreking van bovenstaande tabel beperken we ons voornamelijk tot correlaties met een Pearson $r$ boven .20 .

Allereerst de subschalen van de UCL, de copinglijst. De schaal 'aanpakken' correleert in beperkte mate met de angstschaal $(r=-.21)$. Een iets sterker verband zien we met de SIGFR, de frequentie waarin diverse sociale activiteiten worden uitgevoerd $(r=.27)$.

De subschaal "palliatieven" correleert met angst $(r=.34)$ en met de boosheidsschaal $(r=.28)$.

De subschaal 'vermijden' correleert met de angstdispositie $(r=.29)$ en spanning voor sociale situaties $(r=.32)$ en met boosheid $(r=.21)$.

De schaal 'Social support zoeken' houdt licht verband met de frequentieschaal van de $\operatorname{SIG}(r=.20)$.

De subschaal 'depressief reactiepatroon' correleert hoog met angstdispositie $(r=.67)$, boosheidsdispositie $(r=.42)$ en sociale angst $(r=.36)$ en in iets mindere mate met de JAS $(r=.28)$.

De subschaal 'het uiten van emoties' correleert met de boosheidsschaal $(r=.47)$, met angst $(r=.29)$ en met de JAS $(r=.27)$.

De laatste coping-schaal 'zichzelf geruststellen' correleert met geen enkele psychosociale variabele. 
De score op de ZBV, de angstschaal, correleert goed met de score voor sociale angst $(r=.44)$, met boosheids-dispositie $(r=.53)$ en met het type A-gedrag $(\mathrm{r}=.37)$.

De I-E schaal, de interne-externe beheersingsoriëntatie, correleert niet substantieel met enige andere psychologische variabele.

De JAS, die het type A-gedrag meet, correleert met de boosheidsschaal $(r=.47)$, de angstschaal $(r=.37)$ en UCL-subschaal 'depressief reactiepatroon' $(r=.28)$ en de UCL-schaal 'uiten van emoties' $(r=.28)$.

De SIGSP, de spanningsschaal van de SIG, correleert met de ZBV $(r=.44)$ en de boosheidsschaal $(r=.37)$.

De SIGFR, de frequentieschaal van de SIG, correleert in beperkte mate met de subschaal 'aanpakken' van de UCL $(r=.27)$.

De boosheidsdispositie van de ZAV heeft verscheidene substantiële verbanden zoals met de ZBV $(r=.53)$, met de JAS ( $r=.47)$, met de UCL-schaal 'uiten van emoties' $(r=.47)$. Verder is er nog een verband met de SIPSP $(r=.37)$ en zien we een significante correlatie met de UCL-schaal 'depressief reactiepatroon' $(\mathrm{r}=.42)$.

De VRMG, de gebeurtenissenlijst, heeft met geen enkele andere variabele een redelijk sterk verband, opmerkelijk genoeg ook niet met de JAS en de UCLsubschaal 'aanpakken'.

Tenslotte nog de correlaties van de Defensie Mechanismen Lijst (DMI) met de andere psychologische vragenlijsten. In onderstaande tabel staan de Pearson-correlaties weergegeven.

Tabel 6.9. Pearson correlaties woor de DMI-schalen met de overige in het onderzoek opgenomen psychologische vragenlijsten.

\begin{tabular}{|c|c|c|c|c|c|}
\hline 8 & $\begin{array}{l}\text { Turning } \\
\text { against } \\
\text { object } \\
\text { (TAO) }\end{array}$ & $\begin{array}{l}\text { Projection } \\
\text { (PRO) }\end{array}$ & $\begin{array}{l}\text { Principa- } \\
\text { lisation } \\
(P R N)\end{array}$ & $\begin{array}{l}\text { Turning } \\
\text { against } \\
\text { self } \\
(T A S)\end{array}$ & $\begin{array}{l}\text { Reversal } \\
(R E W)\end{array}$ \\
\hline $\mathrm{ZBV}$ & $.15^{* * *}$ & $.08^{* * *}$ & $-.22 * *$ & $.11 *$ & $-.16^{* * *}$ \\
\hline $1-E$ & $.08^{\text {* * }}$ & $.07^{*}$ & $-.11 *$ & „04 & -.03 \\
\hline JAS & $.19^{* * * *}$ & $.10^{* *}$ & $-.12^{* * *}$ & -.01 & $-.22^{*}$ \\
\hline SIGSP & $.10^{* * *}$ & .03 & -.21 & $16^{*}$ & $-111^{*}$ \\
\hline SIGFR & .01 & .05 & .01 & $-10^{* *}$ & .03 \\
\hline $\mathrm{ZAV}$ & $.28^{* * *}$ & $.13^{* * * * * * *}$ & -.27 & -.02 & $-.22^{*}$ \\
\hline $\begin{array}{l}\text { UCL-A } \\
\text { aanpakken }\end{array}$ & -.01 & .04 & $.10^{* * *}$ & $-.09 *$ & -.02 \\
\hline UCL-P & .03 & $.07 * *$ & $-.08^{*}$ & 04 & $-.07 * *$ \\
\hline
\end{tabular}

$* p=.05 \quad * p=.01 \quad * * * 0.001$ 


\begin{tabular}{lccccc}
\hline & $\begin{array}{l}\text { Turning } \\
\text { against } \\
\text { object } \\
\text { (TAO) }\end{array}$ & $\begin{array}{l}\text { Projection } \\
\text { (PRO) }\end{array}$ & $\begin{array}{l}\text { Principa- } \\
\text { lisution } \\
\text { (PRN) }\end{array}$ & $\begin{array}{l}\text { Torning } \\
\text { against } \\
\text { self } \\
(T A S)\end{array}$ & $\begin{array}{l}\text { Reversat } \\
\text { (REV) }\end{array}$ \\
\hline $\begin{array}{l}\text { UCL-V } \\
\text { yermijden } \\
\text { UCL-S } \\
\text { sociale steun }\end{array}$ & .02 & .02 & -.05 & $.11^{* * *}$ & $-.10^{* *}$ \\
$\begin{array}{l}\text { UCL-D } \\
\text { depressief }\end{array}$ & $.06^{*}$ & .02 & -.04 & -.01 & -.05 \\
$\begin{array}{l}\text { UCL-E } \\
\text { emoties }\end{array}$ & $.12^{* * *}$ & $.11^{* * *}$ & $-.21^{* * *}$ & $.10^{* *}$ & $-.16^{* *}$ \\
$\begin{array}{l}\text { UCL-G } \\
\text { geruststellen }\end{array}$ & $.22^{* * *}$ & $.11^{* * *}$ & $-.18^{* * *}$ & -.06 & $-.18^{* *}$ \\
\hline
\end{tabular}

$* p=.05 \quad * \quad *=.01 \quad * * * a=.001$

Uit bovenstaande tabel valt te concluderen dat de 5 schalen van de DMI slechts enkele significante, substantiële verbanden hebben met de owerige vragenlijsten. Alleen de correlaties tussen de boosheidsdispositie met TAO (.28) en met PRN (-.27) zijn redelijk. Opvallend is het nagenoeg ontbreken van enig duidelijk verband tussen de DMI en de copinglijst UCL, waaruit we kunnen concluderen dat er verschillende hypothetische constructen worden gemeten.

\subsubsection{SECOND ORDER FACTOR ANALYSE}

Om een beter inzicht te krijgen in de samenhang tussen de verschillende constructen zoals gemeten met de betreffende vragenlijsten voeren we op schaalniveau een factoranalyse uit volgens de Hoofdassen-methode (factoren met een eigenwaarde groter dan 1.0 worden verder geroteerd met Varimax). Vervolgens wordt onderzocht of hypertensieven zich van normotensieven onderscheiden op grond van de nieuw verkregen dimensies.

Er worden 30 variabelen in de factoranallyse opgenomen (zie tabel 6.10) hetgeen resulteert in 9 factoren, die ook theoretisch goed interpreteerbaar zijn. Hieronder is de geroteerde factor-matrix weergegeven, waarbij alleen factorscores bowen .30 zijn opgenomen.

De factorindeling laat zich theoretisch goed verklaren. Factor 1 bestaat uit voornamelijk psychologische constructen rondom angst en boosheid. De twee subschalen van de DMI (defensiemechanismen) namelijk 'omkering' en 'acting-out' vormen als tegenpolen een aparte factor (factor 2). De systolische en diastolische bloeddruk, quetelet-index en leeftijd vormen zoals te verwachten was, een aparte factor 3 . In factor 4 zitten 3 subschalen van de copinglijst UCL. Zij vormen met name de meer palliatieve en passieve 
Tabel 6.10. Factor-analyse volgens Hoofdassen-methode met Varimox-methode over alle pariabelen.

\begin{tabular}{|c|c|c|c|c|c|c|c|c|c|}
\hline 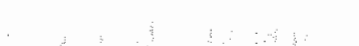 & $F l$ & $F 2$ & $F$ & F4 & $F S$ & $F 6$ & $F 7$ & $F 8$ & $F 9$ \\
\hline ZAV (boosheid) & .75 & & & & & & & & \\
\hline ZBV (angst) & .59 & & & & & .34 & & .43 & \\
\hline JAS (type-A) & .56 & & & & & & & & \\
\hline UCL-K (kwaadheid) & .52 & & & & ? & & & & \\
\hline UCL-D (depressie) & .51 & & & & & & & .44 & \\
\hline SIGSP (spanning) & .35 & . & & & & & & & \\
\hline UCL-S (steum) & .34 & & & & & & & & \\
\hline DMI-REV (omkering) & & -.89 & & & & & & & \\
\hline DMI-TAO/PRO & & .78 & & & & & & & \\
\hline DIASTOLE & & & .78 & & & & & & \\
\hline SYSTOLE & & & .70 & & & & & & \\
\hline QUETELET & & & .32 & & & & & & \\
\hline UCL-G (geruststellen) & & & & .68 & & & & & \\
\hline UCL-V (afwachten/vermijde & & & & .60 & & & & & \\
\hline UCL=P (palliatieven) & & & & .51 & & & & & \\
\hline UCL-A (aanpakken) & & & & & .64 & & & & \\
\hline SIGFR (frequentie spanning & & & & & .42 & & & & \\
\hline IE (beheersingsoriëntatie) & : & & & & -.31 & & & & \\
\hline Werkbelasting & & & & & & .48 & & & \\
\hline Financiële problemen & & & & & & .45 & & & \\
\hline Steun buren & & & & & & & .59 & & \\
\hline Steun vrienden & & & & & & & .54 & & \\
\hline Woondissatisfactie & & & & & & & -.36 & & \\
\hline Steun collaga's & & & & & & & .32 & & \\
\hline Ontevreden met partner & & & & & & & & $\cdot .37$ & \\
\hline Steun familie & & & & & & & &.- .33 & \\
\hline Leeftijd & & & .34 & & & & & & .51 \\
\hline Cholesterol & & & & & & & & & .35 \\
\hline
\end{tabular}

strategieën. In factor 5 zitten de meer actieve strategieën en een interne beheersingsoriëntatie. Werkbelasting en financiële problemen vormen factor 6. De 'social support' variabelen zijn verdeeld over de factoren 7 en 8 . Factor 9 tenslotte wordt gevormd door de variabele leeftijd en cholesterol.

\subsubsection{DATAVERWERKING EN STATISTISCHE PROCEDURES}

Van alle 1097 respondenten zijn de gegevens betreffende leeftijd, bloeddruk, cholesterolgehalte, gewicht en lengte bekend. Ook de gegevens van de psychologische vragenlijsten zijn nagenoeg volledig. Van de Schaal voor 
Interpersoonlijk Gedrag (SIG) ontbreken ongeveer 75 lijsten vanwege een omissie bij de reproductie van het vragenlijstboekje. Van de Defensie Mechanismen Lijst (DMI) ontbreken echter ruim 15\%. Dit is waarschijnlijk te wijten aan de vrij ingewikkelde manier van invullen van de lijst. De overige vragenlijsten zijn goed ingevuld.

Indien meer dan $10 \%$ van het totaal aantal items van een lijst niet goed was ingevuld dan werd de hele lijst als 'missing value' gedeclareerd. Bij het ontbreken van slechts enkele items werd de gemiddelde score van de lijst hiervoor gecorrigeerd door de totalscore te delen door het aantal ingevulde items.

Voor het verkrijgen van de resultaten zoals we die in de volgende paragraaf zullen bespreken, is gebruik gemaakt van de volgende SPSS- en SPSS-Xprogramma's: variantie-analyse met als covariaat de leeftijd, stapsgewijze multiple discriminant analyse, clusteranalyse en multiple regressie-analyse.

\subsection{RESULTATEN}

\subsubsection{VERSCHILLEN TUSSEN HYPERTENSIEVEN EN NORMOTENSIEVEN \\ - leeftijd, quetelet-index, cholesterol en sociale klasse}

De gemiddelde scores op de variabelen leeftijd, quetelet-index, cholesterolgehalte, sociale klasse en bloeddruk van de groep 'hypertensieven' en van de groep normotensieven zijn weergegeven in tabel 6.11 .

Tabel 6.11. Verschillen in gemiddelde scores van normotensieven en hypertensieven en de resultaten van de variantie-analyse met als covariaat de leeftijd.

\begin{tabular}{lcccl}
\hline & $\begin{array}{l}\text { normo- } \\
\text { tensieven } \\
N=770\end{array}$ & $\begin{array}{l}\text { hyper- } \\
\text { tensieven } \\
N=127\end{array}$ & & \\
\cline { 2 - 5 } & $\overline{\mathrm{x}}$ & $\overline{\mathrm{x}}$ & $F$ & $p$-waarde \\
\hline leeftijd & 42.7 & 50.2 & 23.4 & .001 \\
quetelet-index & 245.1 & 260.1 & 17.2 & .001 \\
cholesterol & 5.5 & 5.9 & 1.02 & n.s. \\
sociale klasse & 3.0 & 3.4 & 1.87 & n.s. \\
systolische druk & 129.0 & 155.5 & 354 & .001 \\
diastolische druk & 79.1 & 94.0 & 377 & .001 \\
\hline
\end{tabular}

Het leeftijdsverschil tussen hypertensieven en normotensieven blijkt aanzienlijk. Hypertensie komt met name bij iets oudere mensen voor $(\mathrm{F}=23.4, \mathrm{p}<.001)$. De quetelet-index is eveneens hoger bij hypertensieven vergeleken met normotensieven $(\mathrm{F}=17.2, \mathrm{p}=<.001)$. Ook dit resultaat is conform eerdere bevindingen van onder andere Hofman (1983).

Het serum-cholesterolgehalte bij hypertensieven is volgens verwachting ook 
enigszins hoger. Het verschil is statistisch echter niet significant.

Weliswaar komen de hypertensieven uit een iets hogere sociale klasse, dit verschil is echter niet significant.

De verschillen in systolische en diastolische druk tussen beide groepen spreken voor zich. Opgemerkt moet worden dat in de groephypertensieven zich een aantal personen bevindt dat hypotensieve medicatie krijgt voorgeschreven waardoor de bloeddruk gemiddeld lager zal zijn.

De bloeddruk wordt zoals vermeld twee keer gemeten met een tussenpoze van ongeveer 10 minuten. Het is bekend dat de tweede meting meestal lager uitvalt dan de eerste ("regression to the mean", Valkenburg e.a., 1980). De waarde van de systolische druk van de eerste en tweede meting correleerde; uitgedrukt in Pearson's correlatie maat .87. De diastolische druk correleerde hoger met elkaar $(r=.95)$.

De correlatie tussen de systolische en de diastolische druk bedroeg .55.

\subsubsection{INVLOED VAN MEDICIJNGEBRUIK, DIAGNOSE EN DUUR VAN DE HYPERTENSIE}

\section{MEDICIJNGEBRUIK}

In het BGD-onderzoek, beschreven in H5, is nagegaan of hypertensieven die bloeddrukverlagende medicijnen gebruiken zich psychologisch onderscheiden van de niet-gebruikers. Er werden geen substantiële verschillen aangetroffen tussen de twee groepen hypertensieven. In dit onderhavige onderzoek hebben we gebruikers van hypotensieve middelen onderscheiden (HYPMED) van niet-medicijngebruikers (HYPZONDER) op grond van een schriftelijk antwoord op de vraag: "Heeft $u$ hoge bloeddruk en zoja, krijgt $u$ hiervoor bloeddrukverlagende medicijnen'? Hieronder staan enkele gegevens voor beide groepen met betrekking tot leeftijd, quetelet, sociale klasse en cholesterolgehalte.

Tabel 6.12. Gemiddelden van enkele gegevens wan het periodiek gemeeskundig onderzoek en resulaten van de variantie-analyse.

\begin{tabular}{lccl}
\hline & $\begin{array}{l}\text { hypmed } \\
N=54\end{array}$ & $\begin{array}{l}\text { hypzonder } \\
N=73\end{array}$ & \\
\cline { 2 - 4 } & $\mathrm{x}$ & $\mathrm{x}$ & $p$-waarde \\
\hline leeftijd & 52.6 & 47.8 & $\mathrm{p}<.05$ \\
quetelet & 257 & 262 & $\mathrm{n} . \mathrm{s}^{*}$ \\
sociale klasse & 3.6 & 3.2 & $\mathrm{n.s.*}$ \\
cholesterol & 6.0 & 5.9 & $\mathrm{n.s.*}$ \\
\hline
\end{tabular}

HYPMED $=$ hypertensiewen met bloeddruk verlagende medicijnen HYPZONDER = hypertensieven zonder bloeddrak verlagende medicijnen * variantie-analyse uitgevoerd met als covariaat de leeftijd.

Alleen de verschillen in leeftijd zijn significant. 
Vervolgens is nagegaan (via variantie-analyse met als covariaat de leeftijd) of de beide groepen HYPMED en HYPZONDER verschillen in psychologische kenmerken en sociale omstandigheden. Dit blijkt voor geen enkele variabele het geval te zijn.

\section{IMPACT VAN DE DIAGNOSE}

Een andere variabele die invloed zou kunnen hebben op psychologische kenmerken is bekendheid met de diagnose verhoogde bloeddruk. Om dit te onderzoeken is de totale groep hypertensieven opgedeeld in twee subgroepen namelijk 'HYPBEWUST' versus 'HYPONBEWUST': De samenstelling van deze groepen vindt plaats op grond van de beantwoording van twee vragen die nagenoeg identiek zijn maar in verschillende vragenlijsten zijn opgenomen.

In een vragenlijst die onderdeel uitmaakt van de geneeskundige periodieke keuring van de Nederlandse Spoorwegen wordt gevraagd: 'Is bij u hoge bloeddruk geconstateerd'? De tweede vraag is opgenomen in de lijst 'Levensomstandigheden' en luidt: 'Heeft u hoge bloeddruk'? Indien het antwoord op beide vragen bevestigend is, dan wordt men ingedeeld in de groep HYPBEWUST. Men wordt ingedeeld in de groep HYONBEWUST indien het antwoord 'nee' is, maar bij de medische keuring tot tweemaal toe een te hoge bloeddruk volgens de vastgestelde criteria wordt gemeten. Hieronder staan enkele gegevens van beide groepen:

Tabel 6.13. Gemiddeldien van emkele gegevens van het periodiek geneeskundig anderzoek en de resultaten van de variantie-analyse

\begin{tabular}{lccl}
\hline & $\begin{array}{l}\text { hypbewust } \\
N=81\end{array}$ & $\begin{array}{l}\text { hyponbewist } \\
N=46\end{array}$ & p-waarde \\
\cline { 2 - 4 } & $\overline{\mathrm{X}}$ & $\overline{\mathrm{X}}$ & \\
\hline leeftijd & 51.1 & 45.9 & $\mathrm{p}<.05$ \\
quetelet & 262 & 257 & $\mathrm{n.s} *^{*}$ \\
sociale klasse & 3.5 & 3.3 & n.s.* \\
cholesterol & 5.9 & 5.9 & n.s.* \\
\hline
\end{tabular}

HYPBEWUST = hypertensieven die weten dat ze een te hoge bloeddruk hebben, HYPONBEWUST = personen bij wie tijdens de medische keuring een te hoge bloeddruk wordt geconstateerd.

* variantie-analyse, uitgevoerd met als covariaat de leeftijd

We treffen wederom een significant verschil in leeftijd aan. Toetsen we vervolgens de verschillen in gemiddelden van de diverse psychologische variabelen (variantie-analyse met als covariaat leeftijd), dan constateren we slechts een verschil in het aantal recent meegemaakte gebeurtenissen. De personen in de groep HYPONBEWUST hebben recent meer gebeurtenissen meegemaakt dan die in de groep HYPBEWUST ( $F=4.31, p=.04$ ). Dit is op zich een interessant gegeven en wijst op de mogelijkheid dat het meemaken van aanpassing vereisende gebeurtenissen een bloeddrukverhoging kan 
veroorzaken. Met betrekking tot de psychologische en sociale variabelen is er geen verschil tussen beide groepen.

\section{DUUR VAN DE HYPERTENSIE}

Tenslotte maken we een onderscheid met betrekking tot de tijd dat de hypertensie reeds aanwezig is. De groep HYPBEWUST wordt opgesplitst in een groep personen bij wie de bloeddruk niet langer dan 2 jaar is verhoogd (HYPKORT) en in een groep bij wie dat wel het geval is (HYPLANG). Er is reeds op gewezen dat deze indeling slechts dan betrouwbaar kan geschieden indien de respondenten regelmatig op hypertensie zijn gescreend. Van deze veronderstelling kunnen we niet uitgaan zodat de hieronder vermelde gegevens met de nodige voorzichtigheid geïnterpreteerd moeten worden. Hieronder volgen enkele gegevens van beide groepen.

Tabel 6.14. Gemiddelden van enkele gegevens van het periodiek geneeskundig onderzoek en de resultaten van de variantie-analyse.

\begin{tabular}{lccl}
\hline & $\begin{array}{l}\text { hypkort } \\
N=25\end{array}$ & $\begin{array}{l}\text { hyplang } \\
N=48\end{array}$ \\
\cline { 2 - 4 } & $\mathrm{x}$ & $\mathrm{x}$ & p-waarde \\
\hline leeftijd & 50.2 & 50.8 & n.s. \\
quetelet & 261 & 263 & n.s.* \\
sociale klasse & 3.5 & 3.5 & n.s.* \\
cholesterol & 5.8 & 5.9 & n.s.* \\
\hline
\end{tabular}

HYPKORT = hypertensieven die niet langer dan 2 jaar een verhoogdle bloeddruk hebben, HYPLANG = hypertensieven die langer dan 2 jaar een verhoogde bloeddruk hebben.

* variantie-analyse uitgevoerd met als covariaat de leeftijd

De verschillen in leeftijd, quetelet, sociale klasse en cholesterolgehalte zijn geen van alle significant. Ook treffen we geen onderscheid aan tussen de groepen met betrekking tot de in het onderzoek opgenomen psychologische kenmerken.

\subsubsection{SOCIALE OMSTANDIGHEDEN EN VERSCHILLEN TUSSEN HYPERTENSIEVEN EN NORMOTENSIEVEN}

Bij de toetsing van de verschillen tussen de diverse groepen van hypertensieven, (ingedeeld naar respectievelijk gebruik van medicijnen, bewust van de diagnose hypertensie en duur van de hypertensie) is geconstateerd dat voor geen van de sociale variabelen een statistisch significant werd geconstateerd. Daarom worden normotensieven met hypertensieven vergeleken waarbij dus geen rekening wordt gehouden met bovenvermelde indeling. De resultaten van de verschillende ANCOVA's, waarbij telkens leeftijd als covariaat is opgenomen, staan hieronder vermeld. Toetsing met zowel leeftijd als quetelet-index, veranderde het resultaat niet. Opgemerkt moet worden dat de ruwe scores van de items die tot de betreffende factor behoren, zijn omgezet in z-scores. Dit is noodzakelijk 
ondat enkele items ja/nee antwoorden betreft en op andere items een score mogelijk was van 1 tot 10 .

Tabel 6.15. Verschillen in gemiddelde z-scores op de factoren wan de lijst levensomstandigheden (LOM) van normo- en hypertensieven, berekend volgens ANCOVA met als covariaat leeftijd.

\begin{tabular}{|c|c|c|c|c|}
\hline \multirow[b]{2}{*}{ variabele } & \multirow{2}{*}{$\begin{array}{l}\text { normotensieven } \\
N=770\end{array}$} & \multicolumn{2}{|c|}{$\begin{array}{l}\text { hypertensieven } \\
N=127\end{array}$} & \multirow[b]{2}{*}{$p$} \\
\hline & & 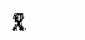 & $F$ & \\
\hline Woondissatisfactie & .06 & -.45 & .34 & n.s. \\
\hline \multicolumn{5}{|l|}{ Sociale steun: } \\
\hline - buren & -.01 & .03 & .65 & n.s. \\
\hline - collega"s & -.01 & .05 & .58 & n.s. \\
\hline - familie & .09 & -.30 & .43 & n.s. \\
\hline - vrienden & .02 & -.11 & 2.00 & $\mathrm{n} . \mathrm{s}$. \\
\hline Partnerrelatie & .01 & -.61 & 2.83 & n.s. \\
\hline Werkbelasting & .05 & -.10 & .22 & n.s. \\
\hline \multicolumn{5}{|l|}{ Financiele } \\
\hline problemen & .01 & -.26 & .02 & n.s. \\
\hline Jeugdervaring & -.05 & .20 & .35 & n.s. \\
\hline \multicolumn{5}{|l|}{ Problemen met } \\
\hline kinderen & 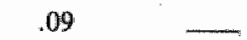 & -.24 & 1.25 & n.s. \\
\hline
\end{tabular}

\section{Woon- en buurtsituatie}

De lijst levensomstandigheden bevat een factor die de mate van ontevredenheid met de woon- en buurtsituatie meet. Over het algemeen is men redelijk tevreden over de woning en de buurt. Door hypertensieven wordt in vergelijking met de normotensieven niet verschillend gescoord.

\section{Sociale steun en partnerrelatie}

Er is een groot aantal items opgenomen die de mate van ervaren sociale steun meten en het netwerk-systeem inventariseren. Uit deze item-pool zijn na factoranalyse 4 subschalen gevormd die respectievelijk de sociale steun meten van buren, collega's, familie en vrienden. Zoals we in tabel 6.15 kunnen zien is er geen enkel significant verschil in z-scores op deze schalen tussen hypertensieven en normotensieven.

Daarnaast is er nog een aparte schaal die de mate van tevredenheid van de partnerrelatie probeert te meten. Onder partner wordt verstaan degene met wie men (al dan niet getrouwd) een vaste relatie heeft en met wie men in één huis samenwoont. Ongeveer $9 \%$ geeft aan geen partner te hebben. De verdeling hypertensief-normotensief is voor deze alleenstaanden niet afwijkend van de verdeling binnen de groep samenwonenden. Degenen die aangeven wel over een partner te beschikken blijken over deze relatie zeer tevreden te zijn. Men zegt dat de partner voldoende aandacht heeft voor de werksituatie en de interesses $(91 \%)$ en dat men persoonlijke moeilijkheden met elkaar bespreekt $(88 \%)$ ). Slechts $10 \%$ zegt dat men er wel eens over gedacht heeft om uit elkaar te gaan en dat men eigenlijk naast elkaar leeft. 
Hypertensieven zijn nog iets meer tevreden met hun partner, maar dit verschil met de normotensieven is niet significant.

\section{Werkbelasting}

Op de vraag 'Hoe tevreden bent u over het geheel genomen met uw huidige werkzaamheden', antwoorden de hypertensieven eveneens niet afwijkend van de normotensieven. Men is redelijk tevreden.

Redenen van ontevredenheid zijn voornamelijk: vaak te koud of te warm $(20 \%)$, te weinig invloed op de werkomstandigheden $(20 \%)$, te weinig beslissingsmogelijkheden (13\%), teveel lawaai $(12 \%)$, teveel stank, stoffig of schadelijke stoffen $(8 \%)$, te weinig afwisseling $(9 \%)$ en te laag inkomen $(12 \%)$.

Een kwart van de respondenten zegt liever een ander soort werk te willen doen en de helft zegt dat bepaalde kanten wan het werk een nadelige invloed op het privé-leven hebben.

Op geen van deze variabelen verschillen hypertensieven van de overige respondenten. Ook komt hypertensie binnen onze onderzoeksgroep niet vaker voor bij bepaalde beroepsgroepen zoals machinisten, dienst- en werkeersleiders. Ze geven niet vaker leiding aan mensen in vergelijking met de normotensieven. Bij de interpretatie van deze gegevens moeten we ons echter realiseren dat onze onderzoeksgroep bestaat uit mensen die binnen het arbeidsproces werkzaam zijn. Degenen die thuis zijn wegens ziekte en dergelijke worden niet voor deze periodieke keuring opgeroepen.

Tenslotte is er nog gekeken naar het aantal werkuren. Ongeveer $19 \%$ van alle respondenten zegt meer dan 40 uur per week te werken. Het percentage hypertensieven binnen deze groep is echter niet verschillend van het percentage in de groep die minder dan 40 uur werkt.

\section{Financiële problemen}

Over het algemeen geven hypertensieven aan iets minder financiële problemen te hebben in vergelijking met de normotensieve groepen. Het verschil is statistisch echter niet significant.

\section{Jeugdervaring}

Een negatieve waardering van de jeugdjaren treffen we over het algemeen aan bij personen met een of meer psychosomatische klachten. Zij voelden zich vroeger vaker alleen staan en konden de problemen niet goed met hun ouders bespreken, er was vaker onenigheid met de ouders en de sfeer thuis ervoer men als minder prettig. Bij hypertensieven wordt deze tendens echter niet aangetroffen. Zij verschillen niet van de totale groep normotensieven.

\section{Problemen met kinderen}

Hypertensieven hebben niet meer problemen met hun kinderen in verband met de opvoeding dan normotensieven. 


\subsubsection{PSYCHOLOGISCHE VERSCHILLEN TUSSEN HYPERTENSIEVEN EN NORMOTENSIEVEN}

Er is reeds geconstateerd dat er geen significant verschil bestaat wat betreft de verschillende psychologische kenmerken tussen de diverse groepen van hypertensieven, ingedeeld naar respectievelijk gebruik van medicijnen, bewust van de diagnose en de duur van de hypertensie. Bij de vergelijking tussen hypertensieven en normotensieven behoeven deze variabelen dus niet als "verstoorders" te worden opgevat.Daarom worden de verschillen getoetst tussen de totale groep van hypertensieven en de groep van normotensieven. In onderstaande tabel hebben we de resultaten van een covariantie-analyse weergegeven waarbij leeftijd als covariaat is opgenomen. Toetsing met als covariaten leeftijd én quetelet-index veranderde het resultaat niet.

Tabel 6.16. Gemiddelde score op de verschillendle persoomlikheidsvrogenijisten wan normo- en hypertensieven, en de resultaten van de variantie-analyses met als covariaat de leefijd.

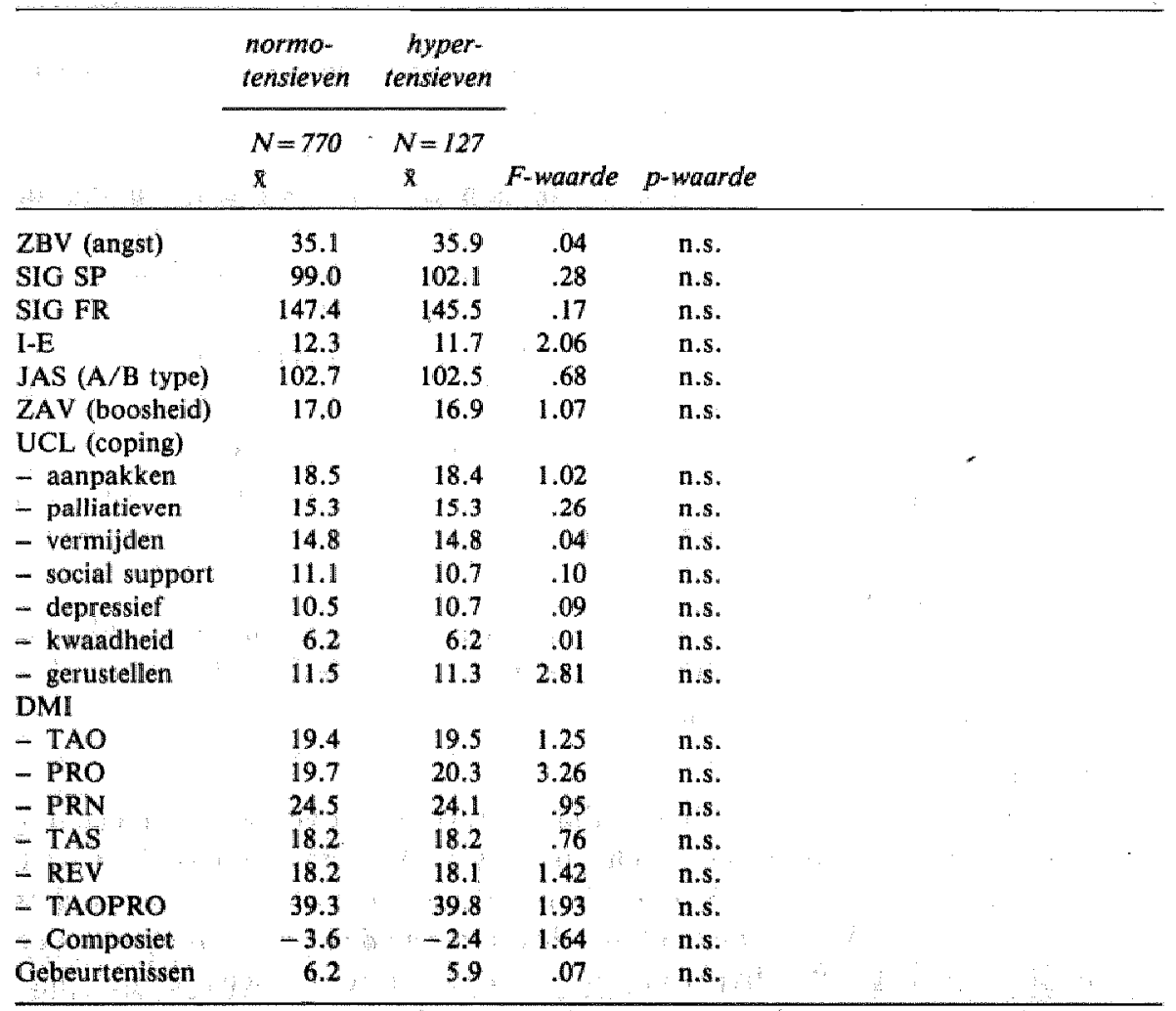

Op grond van de bovenstaande analyses, uitgevoerd op univariaat-niveau, kunnen we constateren dat hypertensieven zich niet onderscheiden van normotensieven met betrekking tot de in het onderzoek opgenomen psychologische variabelen. 
Vervolgens willen we onderzoeken of er op multivariaat niveau een onderscheid gemaakt kan worden tussen beide groepen. Zoals we hebben geconstateerd, vertonen verschillende psychosociale variabelen onderling een gemeenschappelijk verband ( zie par. 6.1.5.2). Ook is het niet uitgesloten dat de aanwezigheid van bepaalde kenmerken op meerdere psychosociale variabelen wel beide groepen $\mathrm{kan}$ onderscheiden. Om dit na te gaan is een multipele discriminant analyse (stapsgewijze) uitgevoerd. De procedure werd uitgevoerd over 16 variabelen; leeftijd, quetelet-index, cholesterol, sociale klasse, ZBV( angst), I-E (beheersingsoriëntatie), JAS (A-type), SIG (sociale angst), ZAV (boosheid), Coping-factoren $A$ en $V$ (aanpakken en afwachten/vermijden), de DMI-schalen TAO/PRO ('acting out') en Reversal, aantal recent meegemaakte gebeurtenissen en de LOM-factoren steun van collega's, steun van familieleden, partnerrelatie en ervaren werkbelasting. Het zijn met name die variabelen waarvan op grond van theoretische overwegingen en op grond van de resultaten van univariate analyses, de best discriminatieve waarde wordt verwacht.

Uiteindelijk zijn 9 variabelen opgenomen in de discriminant functie. In onderstaande tabel zijn de resultaten samengevat.

Tabel 6.17. Stapsgewijze multiple discriminant analyse voor de afhankelijke variabele hypertensie.

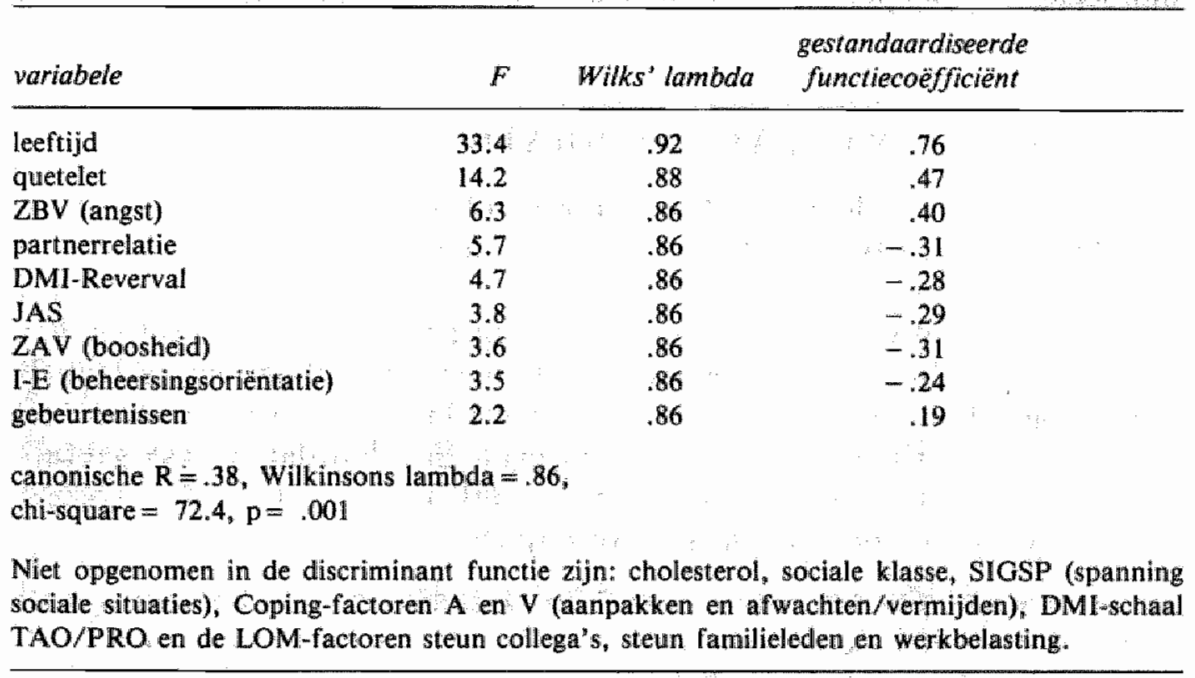

Van de variabelen die zijn opgenomen in de discriminant functie nemen de variabelen leeftijd en quetelet-index de grootste variantie voor hun rekening namelijk ongeveer $10 \%$. Gezamenlijk verklaren alle 9 variabelen slechts $15 \%$ van de totale variantie (canonical $R=.38$ ). Ook de lambda is erg hoog, hetgeen betekent dat de groepen niet zo duidelijk van elkaar verschillen.

Tenslotte willen we nagaan of het gelijktijdig aanwezig zijn van bepaalde 
persoonlijkheidskenmerken, zoals door ons gemeten, meer voorkomt bij hypertensieven dan bij normotensieven.

In paragraaf 6.1.6.3 hebben we de resultaten besproken van een factoranalyse zoals uitgevoerd over de gemiddelden van alle psychosociale variabelen en tevens met de variabelen leeftijd, bloeddruk, cholesterol-gehalte en queteletindex. We hebben reeds opgemerkt dat de factorstructuur zich goed laat interpreteren. Met name factor 1,2,4 en 5 zijn gedragskenmerken die relevant geacht kunnen worden voor de etiologie van essentiële hypertensie. Factor 1 wordt gevormi door constructen rondom de thema's angst en boosheid. De factoren 2,4 en 5 bevatten bepaalde defensie- en copingstijlen. Factor 2 kan worden omschreven als 'naar buiten richten van de aandacht en van agressie', afwachten en vermijden. Factor 4 bevat voornamelijk 'arousal-reducerende strategieën zoals geruststellen, vermijden en ontspaning zoeken. Factor 5 tenslotte bevat veelal copingstrategieën die gericht zijn op het veranderen en controleren van de probleemsituatie.

Via t-testen is nagegaan of de gemiddelde factorscores van hypertensieven en normotensieven op de betreffende factoren van elkaar verschillen. Dit bleek niet het geval te zijn. Deze resultaten zijn in overeenstemming met de hiervoor beschreven analyses en wijzen erop dat hypertensieven op grond van de in dit onderzoek opgenomen psychosociale variabelen niet verschillen van normotensieven.

\subsubsection{SUBTYPEN VAN HYPERTENSIEVEN}

In hoofdstuk 4 is de verwachting uitgesproken dat er binnen de groep hypertensieven een tweedeling kan worden gemaakt op grond van bepaalde gedragskenmerken. Deze gedragskenmerken, met name de wijze waarop met problemen en bedreigende situaties wordt omgegaan, zouden een rol kunnen spelen zowel binnen de etiologie als de instandhouding van essentiële hypertensie. Een subgroep zou zich kenmerken door een 'compulsief' gedragspatroon. De andere groep onderscheidt zich doordat ze vaak gebruik maakt van het defensiemechanisme 'ontkenning' en van passieve copingstrategieën, zoals 'afwachten/vermijden'.

De eerste groep, met het 'compulsieve' gedragspatroon, is in hoofdstuk 4 als volgt geoperationaliseerd: hoge angstscore, hoge score op de boosheidsschaal, een type-A gedrag en volgens de DMI-schaal een 'acting out' gedragspatroon hetgeen betekent dat men defensie-mechanismen gebruikt waarbij de affectregulatie naar buiten is gericht.

De groep 'ontkenners' is als volgt geoperationaliseerd: hoge score op de subschaal 'Omkering' van de DMI en hoge scores op factoren die passieve copingstrategieèn vertegenwoordigen, zoals 'afwachten/vermijden': Men ontkent dat zich vervelende gebeurtenissen hebben voorgedaan en/of dat men 
in minder plezierige levensomstandigheden verkeert. De leefsituatie wordt over het algemeen als gunstig en weinig problematisch beschreven. Men is minder angstig en agressief.

Teneinde exploratief na te gaan of deze tweedeling binnen de populatie van hypertensieven een empirische basis heeft, wordt een clusteranalyse uitgevoerd met behulp van het SPSS-programma Quick Cluster. Het programma clustert een $\mathrm{x}$-aantal subgroepen van respondenten op grond van hun kenmerken op de diverse psychosociale variabelen. Met behulp van deze hiërarchische clusteranalyse (contrastgroepen-analyse) wordt gepoogd groepen te beschrijven die wat betreft de scores op de diverse psychosociale variabelen zo homogeen mogelijk scoren. De variabelen die als basis dienen voor de a priori indeling (zie hypothetische indeling van subgroepen), worden in de clusteranalyse ingevoerd, te weten: ZBV, I-E, JAS, SIGSP, ZAV, UCLfactoren 'Actief aanpakken' en 'afwachten/vermijden', DMI-schalen TAO/PRO en REV. De clusteranalyse wordt uitgevoerd voor 2,3 en 4 subgroepen. Uiteindelijk blijkt dat de analyse, waarbij het programma 2 subgroepen moet onderscheiden, theoretisch het best te interpreteren.

In onderstaande tabel staan de gegevens weergegeven.

Tabel 6.18. Resulaten van de clusteranalyse. De groep hypertensiewen wordt onderverdeeld in twee subgroepen op grond van hun scares op de verschillende psychologische variabelen. De verschillen zijn getoetst met ANCOVA, met als covariaat leeftijd.

\begin{tabular}{|c|c|c|c|c|}
\hline & $\begin{array}{l}\text { Hypersen } \\
\text { chuster } \\
N=46\end{array}$ & $\begin{array}{l}\text { cluster } 2 \\
N=81\end{array}$ & $:$ & \\
\hline & $\pi$ & 8 & F-waarde & $p$-waarde \\
\hline ZEV (angst) & 40.5 & 33.1 & 4,04 & .047 \\
\hline JAS (type A) & 108.2 & 99.3 & 3,08 & .082 \\
\hline SIGSP (sociale angst) & 129.9 & 86.2 & 160.2 & .001 \\
\hline ZAV (boosheid) & 18.5 & 15.9 & 8.47 & .004 \\
\hline IE (beheersing) & 12.8 & 11.0 & 5.88 & .017 \\
\hline TAO/PRO (acting-out) & 41.6 & 38.7 & 4.86 & .030 \\
\hline REV (omkering) & 16.7 & 18.9 & 6.96 & .010 \\
\hline UCL-aanpakken & 17.6 & 18.9 & 2.89 & .091 \\
\hline UCL-vermijiden & 16.1 & 14.1 & 10.6 & 001 \\
\hline
\end{tabular}

Bij nadere beschouwing van de clusterindeling constateren we dat de hypertensieven in cluster 1 zich als volgt laten beschrijven: hoog angstige mensen, die veel spanning ervaren tijdens sociale situaties, een hogere boosheidsdispositie hebben, externer zijn op de beheersingsoriëntatie, hun agressie meer naar buiten richten, maar daarentegen ook meer de passieve copingstrategie hanteren zoals 'afwachten/vermijden'. De hypertensieven in 
cluster 2 zijn in vergelijking met de andere subgroep hypertensieven, significant minder angstig (zowel op de ZBV als op de SIG), hebben een lagere boosheidsdispositie, zijn interner op de beheersingsoriëntatie, keren hun agressie minder naar buiten en ze maken meer gebruik van het defensiemechanisme 'Omkering'.

Indien we deze beschrijvingen vergelijken met de hypothetische operationalisaties van de twee subgroepen hypertensieven, zoals geformuleerd in hoofdstuk 4, dan vallen duidelijke overeenkomsten op. Het lijkt erop dat de verwachting omtrent twee subgroepen bevestigd kan worden.

In voorgaande bespreking is aangetoond dat de hypertensieven zich op univariaat niveau niet onderscheiden van de normotensieven met betrekking tot de meeste psychosociale variabelen. Achteraf zou dit verklaard kunnen worden doordat de scores op verschillende psychosociale variabelen voor de ene subgroep hoog liggen en voor de andere groep laag. De scores van beide subgroepen worden namelijk gemiddeld en vervolgens vergeleken met de scores van de normotensieven.

De hierboven beschreven subgroepindeling van hypertensieven is tot stand gekomen op grond van de clusteranalyse uitgevoerd met die persoonlijkheidsen gedragskenmerken die theoretisch de a priori indeling van hypertensieven zouden operationaliseren. We willen nu nagaan of de, op deze wijze samengestelde subgroepen hypertensieven, zich ook onderscheiden met betrekking tot de overige psychologische en sociale factoren. In onderstaande tabel staat een overzicht van de gemiddelde score op de betreffende psychosociale factoren van achtereenvolgens de hypertensieven in cluster 1 (compulsieven) normotensieven en hypertensieven in cluster 2 (ontkenners). De volgorde is zo gekozen dat in de tabel duidelijk wordt dat de scores van de normotensieven in veel gevallen tussen die van de beide subgroepen hypertensieven liggen.

De verschillen tussen beide subgroepen hypertensieven met betrekking tot quetelet-index, cholesterolgehalte en sociale klasse zijn te verwaarlozen.

Richten we onze aandacht op de subgroep hypertensieven, die door de eerder uitgevoerde clusteranalyse in cluster 1 zijn ondergebracht, dan zien we het volgende beeld: zoals reeds besproken zijn er hoge angstscores op zowel de ZBV als de SIG. Men heeft een hogere boosheidsdíspositie en keert de agressie meer naar buiten. Ook het type A-gedrag is iets nadrukkelijker aanwezig. Een verdere ondersteuning van het bovengeschetste gedragsprofiel vinden we terug in een hogere score op de DMI-schalen TAO en een lagere score op REVERSAL,

Op grond van deze kenmerken zijn ze opgenomen in cluster 1 . Dit geschetste beeld wordt echter nog verder ondersteund door de scores op een aantal andere psychosociale factoren die niet binnen de clusteranalyse waren betrokken. 
Tabel 6.19. De gemididelde scores op de verschillende psychosociale variabelen wan respectievellok hypertensieven in cluster I, normotensieven, hypertensieven in cluster 2 en de resultaten van univariate analyses met als covariaat de leeftid.

\begin{tabular}{|c|c|c|c|c|c|c|}
\hline & $\begin{array}{l}\text { Hyper- } \\
\text { tensief } \\
\text { cluster I } \\
N=46\end{array}$ & $\begin{array}{l}\text { Normo- } \\
\text { tensief } \\
\text { tensief } \\
N=770\end{array}$ & $\begin{array}{l}\text { Hyper- } \\
\text { tensief } \\
\text { cluster } 2 \\
N=81\end{array}$ & & $\therefore$ & \\
\hline & $x$ & $x$ & $x$ & $F$ & $p$-waarde & \\
\hline leeftijd & 51.5 & 42.7 & 49.2 & 23.4 & .001 & \\
\hline quetelet & 26.4 & 24.5 & 25.7 & 9.4 & .001 & \\
\hline cholesterol & 6.1 & 5.5 & 5.8 & 3.12 & n.s. & \\
\hline socilalle klasse & 3.3 & 3.0 & 3.5 & 2.73 & .043 & \\
\hline systole & 156.1 & 129.4 & 155.0 & 145.5 & .001 & \\
\hline diastole & 94.2 & 79.1 & 94.1 & 188.3 & .001 & \\
\hline ZBV* & 40.5 & 35.1 & 33.1 & 12.0 & .001 & \\
\hline JAS* & 108.2 & 102,8 & 99.3 & 5.22 & .006 & \\
\hline SIGSP* & 129.9 & 99.2 & 86.2 & 39.4 & .001 & \\
\hline SIGFR & 142.7 & 147.4 & 146.6 & .22 & n.s. & \\
\hline $\mathrm{ZAV}^{*}$ & 18.5 & 16.9 & 15.9 & 7.48 & .001 & \\
\hline $\mathrm{IE}^{*}$ & 12.8 & 12.3 & 11.0 & 6.79 & .001 & \\
\hline UCL-A* & 17.6 & 18.5 & 18.9 & 1.86 & $\mathbf{n} s$ & \\
\hline UCL-P & 15.4 & 15.3 & 15.2 & .07 & n.s. & \\
\hline UCL-V* & 16.1 & 14.8 & 14.1 & 3.52 & .030 & \\
\hline UCL-S & 10.9 & 11.1 & 10.6 & ${ }_{n} 38$ & $\mathrm{n}, \mathrm{s}$ & \\
\hline UCL-D & 12.0 & 10.5 & 9.7 & 9.31 & .001 & \\
\hline UCL-K & 6.4 & 6.2 & 60 & 1.42 & nis: & \\
\hline UCL-G & 11.4 & 11.5 & 11.2 & 1.45 & n.s. & \\
\hline DMI-TAO & 20.3 & 19.4 & 18.8 & 1.96 & n.s. & \\
\hline DMI-PRO & 20.8 & 19.7 & 19.9 & 2.49 & n.s. & \\
\hline DML-PRN & 23.1 & 24.5 & 24.8 & 3.00 & .050 & \\
\hline DMI-TAS & 18.8 & 18.2 & 17.8 & 1.19 & n:s: & \\
\hline DMI-REV* & 16.7 & 18.2 & 18.9 & $3: 03$ & .049 & \\
\hline DMI-TAO/PRO* & 41.6 & 39.2 & 38.7 & 3.05 & .048 & \\
\hline DMI-COMPOSIET & .83 & -3.6 & -4.8 & 4.10 & .017 & \\
\hline gebeurtenissen & 6.1 & 5.9 & 5.8 & 1.71 & n.s. & \\
\hline woonsituatie & -.59 & .07 & -.37 & 41 & n.s. & \\
\hline steun collegal"s & -.06 & .02 & .22 & .78 & n.s. & \\
\hline buren & -.16 &.$\infty$ & $\therefore \quad 15$ & .24 & $n_{*}$ & \\
\hline familie & -.90 & .01 & .10 & 1.14 & n.s. & \\
\hline vrienden & -.60 & -.15 & .28 & 1.28 & $\mathrm{n} . \mathrm{s}$ & \\
\hline partnerrelatie & .44 & .00 & -.86 & 1.32 & n.s. & \\
\hline werkbelasting & .95 & .14 & -.63 & 3.44 & .003 & \\
\hline jeugdervaring & .07 & -.04 & .34 & .24 & n.s. & \\
\hline financièn & -.22 & .01 & -.27 & .07 & n.s. & \\
\hline
\end{tabular}

* variabelen die betrokken zijn geweest bij de samenstelling van de beide clusters 
Men is volgens de UCL somberder gestemd en piekert veel. Over het algemeen wijst de beantwoording van een aantal vragen van de Lijst Levensomstandigheden erop, dat de werkomstandigheden en het werk minder worden gewaardeerd en het werk als een belasting wordt ervaren; men zegt significant minder vaak een beroep te kunnen doen op de chef. Men heeft vaker problemen met de opvoeding van de kinderen en geeft te kennen dat men het contact met de kinderen dreigt te verliezen en zichzelf tekort voelt schieten als ouder.

De hypertensieven die door de eerder besproken clusteranalyse in cluster 2 worden opgenomen, zijn iets jonger dan de andere subgroep hoewel het verschil met de normotensieven nog steeds aanzienlijk is.

Deze subgroep hypertensieven, zo beschreven we eerder, onderscheidde zich door een lage angstscore op zowel de ZBV als op de SIG en ook een lagere score op de boosheidsdispositie. De score op de JAS is weliswaar lager dan die van normotensieven maar het verschil is niet significant. De scores op de copinglijst UCL wijzen erop dat deze subgroep van hypertensieven aangeeft weinig vermijdingsgedrag te vertonen, geen depressief reactiepatroon heeft en dat de strategie "zichzelf geruststellen" weinig voorkomt. De beantwoording op de DMI geeft een analoog beeld: weinig agressie naar buiten toe gericht maar wel meer gebruik makend van 'Omkering'.

Over het algemeen lijkt het dat de subgroep hypertensieven in dit cluster hun levensomstandigheden gunstiger beoordelen. Men zegt significant vaker dan normotensieven tevreden te zijn over het werk: men verveelt zich niet vaak, men hoeft op het werk niet altijd op te letten en men kan altijd een beroep doen op de chef. Ook kan men weleens iets anders gaan doen. Het werk heeft een minder nadelige invloed op het privé-leven.

Men is in vergelijking met de hypertensieven in cluster 1 en de normotensieven, over het algemeen iets meer tevreden met de woning en de buurt waarin men leeft, stelt contacten met familie en vrienden gunstiger voor en is zeer tevreden over de relatie met partner en de kinderen. Deze verschillen zijn echter net niet significant.

Deze uitvoerige beschrijving waarin een beeld is geschetst van de hypertensieve personen die hun leefsituatie erg gunstig voorstellen, geeft nog geen antwoord op de vraag of dit beeld met de werkelijkheid strookt. Is de situatie waarin men zich bevindt inderdaad gunstiger in vergelijking met anderen of hanteert men een passieve copingstrategie waarbij men problemen niet wil zien en men een ingewikkeld vermijdingsgedrag heeft ontwikkeld? We veronderstellen dat dit laatste het geval zal zijn.

Een belangrijke vraag is in hoeverre een dergelijke clustering van personen op grond van bepaalde psychosociale variabelen kenmerkend is voor subgroepen hypertensieven. Zou een dergelijke clustering niet eveneens tot stand komen binnen de groep normotensieven. Om dit na te gaan is wederom een 
clusteranalyse uitgevoerd met dezelfde variabelen maar nu op de data van alle respondenten. Het Quick Cluster-programma werd wederom opgedragen om twee subgroepen te onderscheiden die zo homogeen mogelijk scoren op de betreffende variabelen. In onderstaande tabel zien we het resultaat:

Tabel 6.20. Clusteranalyse witgevoerd op alle respondenten. Gemiddelde scores wan thee swbgroepen op verschillende psychosociale variabelen zijn getoetst met ANCOVA met als covariaat leeftijd.

\begin{tabular}{|c|c|c|c|c|}
\hline & \multicolumn{2}{|c|}{ Alle respondenten. } & \multirow[b]{2}{*}{$F$} & \multirow[b]{2}{*}{ p-waarde } \\
\hline & $\bar{x}$ & $\mathrm{x}$ & & \\
\hline ZBV (angst) & 40.0 & 32.7 & 178.0 & .001 \\
\hline JAS (type A) & 108.9 & 99.8 & 52.2 & .001 \\
\hline SIGSP (sociale angst) & 126.9 & 82.9 & 1469 & .001 \\
\hline ZAV (boosheid) & 19.1 & 15.6 & 1.12.6 & .001 \\
\hline IE (beheersing) & 13.1 & 11.7 & 25.8 & .001 \\
\hline TAO/PRO (acting-out) & 40.2 & 38.8 & 7.1 & .008 \\
\hline REV (omkering) & 17.6 & 18.4 & 9.5 & .002 \\
\hline UCL-aanpakken & 17.8 & 18.8 & 10.6 & .001 \\
\hline UCL-vermijden & 15.8 & 14.1 & 47.3 & .001 \\
\hline
\end{tabular}

Indien we bovenstaande clustering nader bekijken en vergelijken met het resultaat van de clusteranalyse zoals uitgevoerd op de data van uitsluitend hypertensieven, dan zien we een opmerkelijke gelijkenis. Via crosstabulatie is onderzocht of de verdeling van normotensieven en hypertensieven over beide clusters afwijkt van de te verwachten frequentieverdeling. Dit blijkt niet het geval te zijn. De chi-kwadraat is niet significant $(.14$, n.s. $)$. In onderstaande tabel is de kruistabel weergegeven:

Tabel 6.21 . Crosstabulatie van normom en hypertensieven over de twee chusters die wordien gevormd op grond van de scores op de betreffende variabelen van alle respondenten. De resulatem zijn getoetst met chi-kwadraat.

\begin{tabular}{lll} 
& cluster 1 & chuster 2 \\
\hline normotensieven & $\mathrm{N}=266$ & $\mathrm{~N}=504$ \\
hypertensieven & $\mathrm{N}=53$ & $\mathrm{~N}=74$ \\
\hline
\end{tabular}

Dit resultaat doet vermoeden dat de gedragskenmerken zoals genoemd in cluster 1 van de hypertensieven (angstig en boos) en in cluster 2 (ontkenners) geen specifieke kenmerken zijn voor uitsluitend hypertensieven. Ook bij normotensieven treffen we een dergelijke subgroep-indeling aan. 


\subsubsection{INTERACTIES TUSSEN SOCIALE FACTOREN EN PERSOONLIJKHEIDSKENMERKEN}

Het model dat we hebben besproken in hoofdstuk 4 en dat aanvangt met een psychosociale stressor en uiteindelijk resulteert in essentiële hypertensie, is uiterst ingewikkeld vanwege de vele mogelijke interacties tussen verschillende variabelen. Het model gaat ervan uit dat er een samenspel is tussen stabiele persoonsgebonden eigenschappen en 'life events' die zich binnen een bepaalde sociale context afspellen. Daarnaast worden er in het model ook nog enkelle biologische en constitutionele variabelen genoemd die mede bepalen of zich in latere jaren een hypertensie zal ontwikkelen. Welke variabelen en welke interacties het belangrijkst zijn, wat betreft de etiologie van essentiële hypertensie, blijft voorlopig nog een onbeantwoorde vraag. We hebben niet de pretentie gehad om het onderzoeksmodel in zijn geheel te toetsen. Om dit te kunnen doen dient een andere onderzoeksmethode gevolgd te worden. Hierbij is het in ieder geval noodzakelijk om een grote groep mensen (zowel hypertensief, pre-hypertensief als normotensief) gedurende langere tijd psychologisch en sociaal te volgen.

Het NS-onderzoek is cross-sectioneel en descriptief van aard. Er wordt op een bepaald moment in de tijd geïnventariseerd welke psychologische kenmerken de respondenten bezitten en in welke sociale omstandigheden ze momenteel. verkeren. De etiologische rol van sociale factoren is in een dergelijke crosssectionele studie niet aantoonbaar. Het is namelijk niet goed te achterhalen welke sociale omstandigheden er aanwezig waren op het moment dat een tijdelijk verhoogde bloeddruk op den duur resulteerde in een chronische hypertensie. Ook in retrospectief opzicht is de relatie tussen sociale omstandigheden en hypertensie moeilijk te achterhalen. Dit komt door een beperkt en selectief geheugen van de respondenten maar ook omdat essentiële hypertensie in de beginfase nauwelijks gepaard gaat met merkbare lichamelijke klachten of symptomen ('silent disease') waarvoor men zich onder medische behandeling stelt. In veel gevallen wordt een verhoogde bloeddruk 'toevallig' ontdekt tijdens een medische keuring voor bijvoorbeeld een andere baan, het afsluiten van een levensverzekeringspolis of tijdens deelname aan een bevolkingsonderzoek. Het is mogelijk dat de dan geconstateerde hypertensie reeds jarenlang aanwezig kan zijn. Zoals bekend past het cardiovasculair systeem zich aan aan de verhoogde druk op de vaatwanden. Er treden structurele veranderingen op die veelal onomkeerbaar worden geacht. De sociale omstandigheden die mogelijk hebben bijgedragen tot de ontwikkeling van de te hoge bloeddruk, kunnen (jaren later) totaal veranderd zijn.

Alle reserves in achtnemend willen we toch een poging wagen om de interactieeffecten op de bloeddruk na te gaan van enkele psychologische en sociale variabelen. We willen nagaan of we de gegevens van Theorell (1976), Harburg 
(1973, 1979), Gentry (1982) en Cottington e.a. (1985) zoals besproken in paragraaf 2.6.1 enigszins kunnen repliceren. We zullen kort de belangrijkste gegevens van deze studies memoreren.

In een onderzoek van Theorell (1976) wordt een interactie-effect tussen sociale en psychologische variabelen met een te hoge bloeddruk geconstateerd. Er worden geen directe verbanden aangetroffen tussen de mate van verantwoordelijkheid op het werk, tevredenheid met het werk en de bloeddruk. Ook wordt geen verband aangetoond tussen gevoelens van vijandigheid en hypertensie. Wel was er sprake van een hogere bloeddruk wanneer er zowel een hogere werkbelasting als gevoelens van vijandigheid aanwezig waren.

Ook in het epidemiologisch onderzoek van Harburg e.a. $(1973,1979)$ wordt een interactie-effect tussen bloeddruk en drie verschillende psychosociale variabelen aangetoond, te weten verhoogde vatbaarheid op constitutionele basis (zwarte versus blanke respondenten), omgevingsfactoren (wijken met. een hoge en met een . lage 'stress', gedefinieerd volgens hoge bevolkingsdichtheid, mobiliteit, criminaliteit, laag inkomen) en tenslotte de copingstijl (met name uiten of inhiberen van gevoelens van boosheid en schuldgevoelens). Naast een direct verband van deze variabelen met de bloeddruk trof men de hoogste diastolische druk aan bij die mensen die hoog scoorden op alle drie de risicofactoren.

Gentry (1982) en Cottington (1985) merken op dat personen die gevoelens van woede onderdrukken en dat vaak doen gezien de aard van de sociale omstandigheid waarin zij verkeren (in dit geval een chronische werkbelasting) een grotere kans lopen om hypertensie te ontwikkelen.

In ons onderzoek kunnen we dit nagaan via de scores op de ZAV (boosheidsdispositie) en werkbelasting. Hieronder staan de resultaten vermeld van een multiple stapsgewijze regressie-analyse.

Tabel 6.21. Multiple stapsgewijze regressie-analyse mer als afhankelijke variabele hypertensie en als onafhankelijke: de leeftijd, de gemiddelde scores op de LOM-schaal werkbelasting en de ZAI $V$ (boosheidsdispositie) en de interactie tussen werkbelasting en boosheid.

\begin{tabular}{lllllll}
\hline & \multicolumn{3}{l}{ hypertensite } & & & \\
\cline { 2 - 6 } variabele & simple $R$ & multiple $R$ & bêta & & Fcchange & sign \\
\hline leeftijd & .24 & .24 & .24 & 38.0 & .001 \\
ZAV X werkbelasting & .01 & .24 & .34 & 1.1 & n.s. \\
ZAV (boosheid) & -.01 & .25 & -.05 & 1.9 & n.s. \\
werkbelasting & -.02 & .25 & -.30 & 5.4 & .02 \\
\hline
\end{tabular}

Zoals we kunnen constateren voegt de interactiemaat $\mathrm{ZAV}^{*}$ : werkbelasting niets extra toe aan de verklaarde variantie voor de afhankelijke variabele hypertensie. 
Er zijn nog diverse andere regressie-analyses uitgevoerd met een aantal andere interactiematen waarvan in tabel 6.22 een kort overzicht van de resultaten zijn vervat.

Het betreft analyses waarvan de volgende afhankelijke variabelen zijn opgenomen:

- leeftijd, werkbelasting, ZAV (boosheidsdispositie), JAS (type-A) en de interactiemaat tussen deze laatste 3 variabelen,

- leeftijd, werkbelasting, ZAV, LOM-schaal partnerrelatie, en de interactiemaat tussen deze laatste 3 variabelen,

- leeftijd, werkbelasting, ZAV, LOM-schaal 'support vrienden' en de interactiemaat tussen deze laatste 3 variabelen,

- leeftijd, beheersingsorientatie (I-E), aantal recent meegemaakte gebeurtenissen en de interactiemaat tussen deze laatste 2 variabelen,

- leeftijd, werkbelasting, UCL-schaal 'afwachten/vermijden' en de interactiemaat tussen deze laatste 2 variabelen,

- leeftijd, werkbelasting, UCL-schaal 'aanpakken' en de interactiemaat tussen deze laatste variabelen.

Tabel 6.22. Samenvatting wan enkele multiple stapsgewijze regressie-analyses met als afhankelijke variabelen hypertensie. Weergegeven zijm alleen de gegevens m.b.t. leefijid en de interactiemaat.

\begin{tabular}{|c|c|c|c|c|c|}
\hline \multirow[b]{2}{*}{ variabele } & \multicolumn{5}{|c|}{ afhanklijke variabele hypertensie } \\
\hline & simple $R$ & multiple $R$ & bêta & F-change & sign \\
\hline leeftijd & .24 & .24 & .24 & 48.3 & .001 \\
\hline $\begin{array}{l}\text { werkbelasting } \mathrm{ZAV} \times \\
\text { JAS }\end{array}$ & .01 & .25 & .17 & .9 & n.s. \\
\hline leeftijd & .24 & .24 & .24 & 44.1 & .001 \\
\hline $\begin{array}{l}\text { werkbelasting } \times \mathrm{ZAV} \times \\
\text { partnerrelatie* }\end{array}$ & .01 & .24 & -.05 & $\mathbb{1 . 2}$ & n.s. \\
\hline leeftijd & .24 & .24 & .24 & 47.8 & .001 \\
\hline $\begin{array}{l}\text { werkbelasting } \times 2 \mathrm{AV} \times \\
\text { stewn vrienden* }\end{array}$ & .05 & .27 & .23 & 4.9 & .03 \\
\hline leeftijd & .24 & .24 & .24 & 46.7 & .001 \\
\hline I-E $\times$ Events $x$ & .06 & .27 & -.39 & 9.7 & .02 \\
\hline leeftijd & .24 & .24 & .24 & 49.1 & .001 \\
\hline werkbelasting $\times U C L-V>$ & $\times .01$ & .24 & .02 & - & n.s. \\
\hline werkbelasting $\times$ UCL-A & $\times .01$ & .24 & .01 & - & n.s. \\
\hline
\end{tabular}

We zien in enkele gevallen dat de bêta gewichten hoger uitvallen maar in geen van de regressie-analyses neemt een interactiemaat een redelijk deel van de verklaarde variantie voor zijn rekening. De meeste variantie wordt opgeëist door de variabele leeftijd. De interactie tussen werkbelasting, ZAV en steun 
van vrienden en de interactie tussen de beheersingsorièntatie en het aantal recent meegemaakte gebeurtenissen dragen weliswaar significant bij aan de variantie, maar het betreft echter een relatief geringe bijdrage. Het wijst wel in de richting dat toekomstig onderzoek op dit gebied zich moet concentreren op interacties tussen psychologische en sociale factoren bij pre-hypertensieven die gedurende enkele jaren worden gevolgd. 


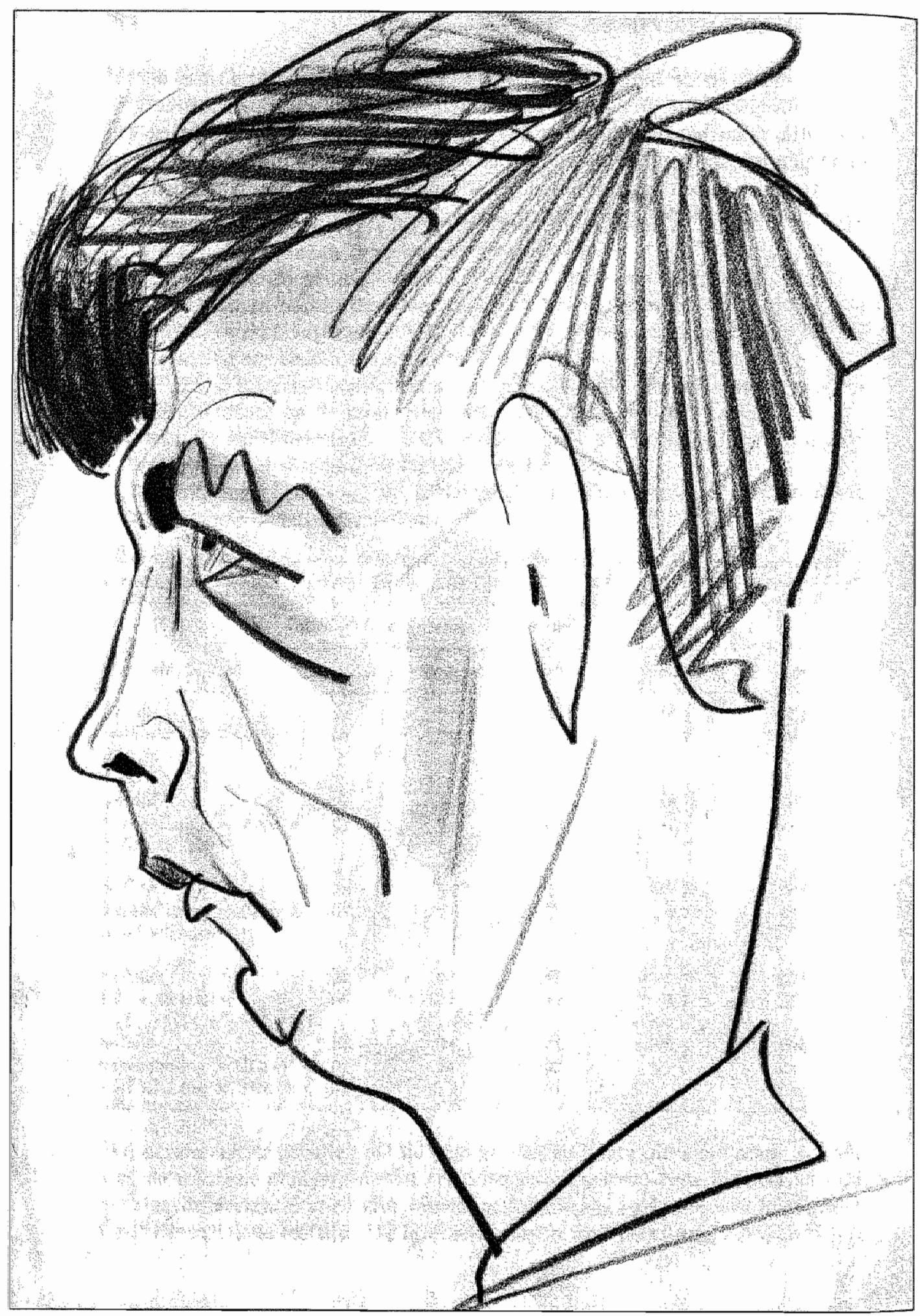




\section{HOOFDSTUK 7}

\section{NABESCHOUWING}

In de onderzoeken zoals beschreven in hoofdstuk 5 en hoofdstuk 6 is getracht enkele onderdelen nader te bestuderen van het onderzoeksmodel (hoofdstuk 4) betreffende de relatie tussen psychosociale factoren en essentiële hypertensie. In eerste instantie hebben we willen onderzoeken of bepaalde persoonlijkheidskenmerken vaker voorkomen bij hypertensieven dan bij normotensieven.

De onderzoeken zijn cross-sectioneel van aard zodat er geen uitspraak gedaan kan worden over causale relaties. De belangrijkste resultaten vatten we hieronder samen.

\subsection{INDELINGSCRITERIA VOOR HYPERTENSIE EN NORMOTENSIE}

Het samenstellen wan de groepen 'hypertensief' en 'normotensief' kan alleen maar op arbitraire wijze plaatsvinden. Internationaal worden er verschillende indelingscriteria gehanteerd met betrekking tot de hoogte van de bloeddruk (Jenkins e.a. 1984). De vele strijdige onderzoeksresultaten op het gebied van persoonlijkheidskenmerken en hypertensie, zoals we die in het theoretische gedeelte hebben besproken, kunnen mede hierdoor worden verklaard. Zowel in het BGD-onderzoek als in het NS-onderzoek werd de groep hypertensieven gevormd door personen die een gemiddelde bloeddruk hadden hoger of gelijk aan $160 / 100 \mathrm{~mm} \mathrm{Hg}$ en/of die vanwege hypertensie bloeddrukverlagende middelen gebruikten. We zijn nagegaan of een ander en mogelijk strenger criterium voor de NS-populatie ook een ander resultaat zou opleveren met betrekking tot psychosociale kenmerken tussen hypertensieven en normotensieven. Daartoe werd als enige criterium gehanteerd: de gemiddelde diastolische bloeddruk hoger dan of gelijk aan $100 \mathrm{~mm} \mathrm{Hg}$. De groep van 40 hypertensieven die op deze wijze werden geselecteerd is gemiddeld significant ouder dan de groep normotensieven ( 49 versus 43 jaar, $\mathrm{p}=.001$ ), heeft een hoger cholesterolgehalte $(6.2$ versus $5.5, F=4.41, p=.045)$ en heeft een hogere quetelet-index ( 267 versus $245, F=15.8, p=.001$ ). Ze verschilt niet in sociale klasse. Evenmin verschillen de scores op de psychosociale variabelen (gecorrigeerd voor leeftijdsverschillen). De resultaten wijken hiermee niet af van die zoals besproken in hoofdstuk 6, waar de groep hypertensieven werd gevormd door hantering van een iets ruimer criterium. We handhaven dus ons eerder vastgesteld criterium voor de samenstelling van de groepen 'hypertensief' en 'normotensief'. 


\subsection{MEDICIJNGEBRUIK}

In het theoretisch gedeelte hebben we de mogelijkheid besproken dat hypertensieven die bloeddrukverlagende middelen gebruiken zich op psychosociale aspecten onderscheiden van de niet-gebruikers. Door onder andere Cochrane (1973) is er op gewezen dat bepaalde persoonlijkheidskenmerken kunnen predisponeren tot het al dan niet inroepen van medische hulp. We zijn niet in staat om deze vraagstelling methodologisch verantwoord te onderzoeken. Dit vereist een andere onderzoeksopzet die het 'compliancegedrag' beter onder controle kan houden. Bekijken we desondanks de gegevens van het BGD-en het NS-onderzoek, dan treffen we slechts zeer geringe psychologische verschillen aan tussen hypertensieven die zeggen medicijnen te gebruiken en hypertensieven die geen medicatie ontvangen. In het BGD- onderzoek wordt op de schalal 'Extraversie' hoger gescoord door medicijngebruikers. Tevens scoren zij lager op de DMI-schaal 'Omkering": zij maken dus minder gebruik van defensiemechanismen zoals ontkennen, negeren of verdringen. De schaal 'Extraversie' is niet opgenomen in de testbatterij van het NS-onderzoek, waardoor replicatie niet mogelijk is. De verschillen op de DMI-schaal 'Omkering' vinden we niet terug in het NSonderzoek. Weliswaar is een verkorte versie van de schaal gebruikt maar dit zou het resultaat niet wezenlijk mogen veranderen gezien de nauwelijks afwijkende psychometrische eigenschappen van de twee versies van deze DMIschaal.

\subsection{IMPACT DIAGNOSE EN DE DUUR VAN DE HYPERTENSIE}

Ook het zich bewust zijn van de gestelde diagnose hypertensie kan zijn weerslag hebben op de beantwoording van een aantal vragen met betrekking tot de psychosociale toestand, zo stelden wij in paragraaf 2.6 .6 vast. In het BGD-onderzoek bestond de populatie hypertensieven uitsluitend uit personen die zich bewust waren van hun te hoge bloeddruk zodat we deze veronderstelling niet kunnen toetsen.

In het NS-onderzoek kunnen we een groep hypertensieven selecteren bij wie voor het eerst een te hoge bloeddruk wordt geconstateerd. Deze groep hypertensieven verschilt in psychologisch opzicht niet wezenlijk van de andere groep hypertensieven. $\mathrm{Ze}$ rapporteren wel meer recent meegemaakte gebeurtenissen. Dit is een interessant gegeven en een bevestiging van de 'life events theorie' zoals geformuleerd door Holmes en Rahe (1967) die stelt dat het meemaken van aanpassing vereisende gebeurtenissen een effect kan hebben op het lichamelijk functioneren en het ontwikkelen van klachten. De verhoogde activiteit van het sympatische zenuwstelsel kan de bloeddruk gedurende langere tijd verhogen. Deze 'life event theorie' vormt ook een essentieel bestanddeel van het onderzoeksmodel voor het ontstaan van essentiële hypertensie zoals beschreven in hoofdstuk 4 . In dit model vormen 
psychosociale stimuli weliswaar het beginpunt van een proces maar het is van groot belang hoe er met die stressoren wordt omgegaan. Dit copinggedrag wordt mede bepaald door verschillende persoonlijkheidskenmerken en door eerdere leerervaringen. We hebben onderzocht of de groep hypertensieven, bij wie pas recent de bloeddruk was verhoogd, ook in psychologisch opzicht verschilden van de andere hypertensieven. In het BGD-onderzoek (casecontrol study) bleek een verschil te bestaan: hypertensieven bij wie pas de bloeddruk verhoogd was, bleken volgens de DMI-schaal 'Turning against object' hun agressie meer naar buiten te richten. Het is dus mogelijk dat deze groep hypertensieven op ineffectieve wijze met problemen en gebeurtenissen omgaat en dat dit kan leiden tot een verhoogde bloeddruk. Een bevestiging van dit resultaat kunnen we echter niet terugvinden in het NS-onderzoek (survey-onderzoek). Helaas is in dit geval een exacte vergelijking niet mogelijk vanwege de verkorte versie van de DMI die is gebruikt.

\subsection{SOCIALE OMSTANDIGHEDEN}

Dat hypertensie meer voorkomt bij de lagere sociaal-economische klasse wordt door de resultaten van enkele Amerikaanse survey-studies gesuggereerd (WHO, 1983; Harburg e.a.,1973, 1979). In West-Europa is dit verband niet aangetroffen. Ook in onze onderzoeken is een dergelijke relatie tussen sociale klasse en hypertensie niet aangetroffen. Eerder is van het tegenovergestelde sprake: de hypertensieven komen over het algemeen uit een hogere sociale klasse dan normotensieven, maar dit verschil is statistisch niet significant. In de betreffende Amerikaanse studies werd de zogenaamde lagere sociaal economische klasse voornamelijk gevormd door immïgranten die veelal een andere culturele achtergrond hebben en die mogelijk allerlei aanpassingsproblemen kennen. Er kunnen dus andere variabelen in het geding zijn. Een vergelijkbare groep van respondenten is echter zowel in het BGD-als in het NS-onderzoek niet vertegenwoordigd. Het betreft respondenten die allen zijn opgenomen in het arbeidsproces in tegenstelling tot de respondenten uit de Amerikaanse studies.

Ook met betrekking tot de andere sociale factoren en levensomstandigheden zoals woonomstandigheden, werkbelasting, partnerrelatie en sociale netwerk, vinden we geen significante verschillen tussen hypertensieven en normotensieven. Het ontbreken van deze significante verschillen tussen hypertensieven en normotensieven achten wij conform de verwachting. De veronderstelling van een dergelijk verband zoals gesuggereerd door Eide (1982), kan zich namelijk niet baseren op een uitgewerkt theoretisch fundament. Wel is het mogelijk dat er interactie-effecten zijn tussen sociale omstandigheden, persoonlijkheidskenmerken en copinggedrag, hetgeen tot uiting komt in een verhoogde bloeddruk. Een mogelijke aanwijzing hiervoor hebben we aan het einde van hoofdstuk 6 besproken. Ook de onderzoeksresultaten van Harburg e.a. $(1973,1979)$, Cottington e.a. (1985), 
Gentry e.a. (1982) en Spielberger e.a. (1985) wijzen sterk in deze richting. Om deze interactie tussen sociale omstandigheden en gedragskenmerken en de invloed op de bloeddruk nauwkeuriger te onderzoeken, is meer intraindividueel onderzoek noodzakelijk. Pre-hypertensieven, hypertensieven en normotensieven zullen gedurende langere tijd gevolgd moeten worden, waarbij centraal staat: het copinggedrag bij verschillende aanpassing vereisende gebeurtenissen en de bloeddruk-effecten op korte en langere termijn.

\subsection{PSYCHOLOGISCHE KENMERKEN}

\subsubsection{ANGST EN NEUROTICISME}

In het BGD-onderzoek is gebruik gemaakt van de Taylor Manifest Anxiety Scale als angstmaat. We constateerden dat hypertensieven, van wie allen zich bewust waren van de diagnose hypertensie, hoger scoorden op deze lijst en bevestigden daarmee eerdere onderzoeken (Baer e.a. 1979). In het NSonderzoek hebben we gebruik gemaakt van de State-Trait Anxiety Inventory om de angstdispositie te meten. Deze lijst wordt internationaal weelvuldig gebruikt (Banahan e.a. 1979; Schalling, 1984; Van der Ploeg e.a. 1985) en we zijn daarom in staat onze resultaten beter te vergelijken. Wij vinden geen verschil in angstdispositie tussen hyper- en normotensieven en wijken hiermee af van genoemde publicaties op dit terrein.

Vergelijken we echter de groep hypertensieven met normotensieven die geen enkele (psycho)somatische klacht hebben, dan is er wel sprake van een significant verschil. Dit kan erop wijzen dat angst een centraal concept vormt voor de etiologie van psychosomatische klachten en niet zozeer een kenmerk is van uitsluitend hypertensieven.

Het overzicht van de onderzoeken met betrekking tot de relatie neuroticisme en hypertensie (zie par 2.6.2) leidde tot de conclusie dat er mogelijk belangrijke verschillen zijn in neuroticisme tussen hypertensieven die zich bewust zijn van hun te hoge bloeddruk en hypertensieven die dat niet zijn. Tevens werd er op gewezen dat een mogelijke selectie-bias kan zijn opgetreden ondat de onderzoeksgroep voomamelijk uit hypertensie-patiënten bestond die werden gerecruteerd uit het medische kanaal.

In het BGD-onderzoek werd gebruik gemaakt van de Neuroticisme-schaal van de Eysenck Personality Inventory. De verschillen in gemiddelde score op deze lijst tussen hyper-en normotensieven is niet significant. In het NS-onderzoek is deze lijst niet meer opgenomen in de testbatterij, zodat replicatie niet mogelijk is.

\subsubsection{SOCIALE ANGST EN SUBASSERTIVITEIT}

Zowel in het eerst uitgevoerde onderzoek (BGD-onderzoek) als in het tweede 
onderzoek (NS-onderzoek) treffen we geen enkel significant verband aan tussen de beide schalen 'spanning' en 'frequentie"' van de SIG. Op grond van de beantwoording van de items van deze lijst die pretendeert de mate van angst in sociale situaties te meten en de mate waarin men deze probeert te vermijden, kunnen we stellen dat hypertensieven niet subassertiever zijn dan de andere groep respondenten.

Deze bevinding is in strijd met de conclusies die Linden en Feuertstein (1983), Saslow e.a. (1950) en Manuck e.a. (1984) trekken op grond van hun onderzoeken. Een vergelijking met deze studies is echter moeilijk te maken omdat andere meetinstrumenten gebruikt werden en er ook sprake is van een andere onderzoeksopzet.

Wij hebben gebruik gemaakt van de Schaal voor Interpersoonlijk Gedrag (Arrindel e.a., 1984), een lijst die voldoende betrouwbaar en valide mag worden verondersteld. Op grond van deze resultaten kunnen wij stellen dat hypertensieven niet méér sociaal-angstig zijn en niet subassertiever zijn in vergelijking met mensen met een normale bloeddruk. Een dergelijke bevinding hebben wij ook reeds eerder geconstateerd in een onderzoek van het Gezondheidscentrum Krimpen aan de IJssel: Aan ongeveer 700 respondenten van het bevolkingsonderzoek ter opsporing van hoge bloeddruk, werd de Willems Sociale Angst-lijst (Willems e.a. 1973) voorgelegd. Deze lijst meet de mate van sociale angst. We troffen geen direct verband aan tussen de hoogte van de bloeddruk en de score op deze lijst (Schreurs, Van Son, Godaert, 1976).

\subsubsection{BEHEERSINGSORIËNTATIE}

Voor zover ons bekend zijn er slechts 2 onderzoeken gepubliceerd met betrekking tot de relatie tussen hypertensie en het construct 'locus of control' (Rotter, 1966) ofwell beheersingsoriëntatie. Wennerholm en Zarle (1976) treffen geen verschil aan tussen mate van interne of externe beheersingsoriëntatie en bloeddruk. In het onderzoek van Naditch (1974) werd gesteld dat 'externaliteit' als een moderator variabele is op te vatten tussen mate van ontevredenheid en hypertensie: mensen die erg ontevreden zijn en die tegelijkertijd het idee hebben geen invloed op hun omgeving te kunnen uitoefenen, hebben vaker hypertensie. Een directe relatie tussen beheersingsoriëntatie en hypertensie hebben wij echter in de beide onderzoeken niet kunnen aantonen.

Ook in het reeds genoemde bevolkingsonderzoek ter opsporing van hoge bloeddruk in Krimpen aan de IJssel hebben wij geen direct verband kunnen aantonen tussen "locus of control' en de hoogte van de bloeddruk (Schreurs en Corpeleijn, 1977). Ook in dit onderzoek maakten wij gebruik van de door Rodenburg (1974) vertaalde versie van de Rotter internal-external locus of control scale' (Rotter, 1966). Het is geen eenvoudige lijst om in te vullen en 
er kunnen twijfels gezet worden bij de begripswaliditeit en de betrouwbaarheid van de lijst. Mogelijk dat hierdoor het resultaat enigszins is beïnvloed. Reeds in paragraaf 2.6.4 is er op gewezen dat het construct 'locus of control' uiterst complex is en dat er mogelijk meer dimensies aan ten grondslag liggen (Cohen-Kettenis, Dekking, 1980; Halfens, 1985). Een alternatief was geweest de 'Interne-externe' lijst van Andriessen (1972) op te nemen in het onderzoek. Gezien de lengte en de lay-out van de lijst ( $t$ wee instructies) hebben we hierwan afgezien. Overigens verwachten we ook met deze lijst geen ander resultaat met betrekking tot de relatie 'locus of control' en hypertensie. Wel verwachten wij dat de beheersingsoriëntatie een belangrijke rol kan spelen met betrekking tot de wijze van omgaan met problemen en bedreigende situaties. We hebben dit echter niet gedetailleerd kunnen nagaan.

\subsubsection{TYPE-A GEDRAGSPATROON}

De conclusie die we op grond van beide onderzoeken kunnen trekken is dat er geen directe relatie bestaat tussen de score op de JAS en hypertensie. Dit resultaat komt overeen met onze conclusie die we stelden na analyse van de betreffende onderzoeken op dit gebied (zie 2.6.5).

\subsubsection{BOOSHEIDSDISPOSITIE}

Een directe relatie tussen hypertensie en de score op de ZAV, de schaal die de mate van boosheidsdispositie meet, wordt in geen van de door ons uitgevoerde onderzoeken geconstateerd. In paragraaf 2.6 .1 hebben we uitvoerig aandacht besteed aan de relatie onderdrukte agressie en hypertensie. We hebben gewezen op het AHA syndroom zoals geïntroduceerd door Spielberger (1985). Hij wil hiermee aangeven dat er een grote begripsverwarring bestaat tussen Anger, Hostility and Agression. Ook in het Nederlands taalgebied zijn de begrippen woede, boosheid en agressie niet altijd duidelijk te scheiden. Het instrument dat wij hanteerden om de mate van boosheidsdispositie te meten, de ZAV, is vrij goed gevalideerd. Het blijft echter een vraag of middels het afnemen van de ZAV nagegaan kan worden of mensen in interpersoonlijke relaties hun gevoelens van woede en boosheid onderdrukken. Dit is waarschijnlijk beter mogelijk in een rollenspelsituatie zoals is toegepast door Linden en Feuerstein (1983). Afgaande op onze resultaten kunnen we stellen dat een direct verband tussen score op de ZAV en hypertensie niet aanwezig is. Wel is het mogelijk dat gelijktijdige aanwezigheid van andere factoren, zoals een chronische werkbelasting of een slechte partnerrelatie het effect op de bloeddruk door het onderdrukken van boosheid kan versterken. De onderzoeken van Harburg e.a. $(1973,1979)$, Gentry e.a. (1982) en Cottington e.a (1985) wijzen duidelijk in deze richting.

\subsubsection{DEFENSIEMECHANISMEN}

In hoofdstuk 3 en 4 is de mogelijkheid geopperd dat een bepaalde groep 
hypertensieven het bestaan van problemen en stressvolle gebeurtenissen vaak zou ontkennen. Deze groep zou positiever of neutraler reageren op situaties die bij andere mensen vaak een emotionele reactie oproepen. Ook in het onderzoek van Minsky (1978) werd aangetoond dat hypertensieven meer gebruik maken van de defensiemechanismen 'ontkenning' en 'repressie' zoals gemeten met de 'Defense Mechanism Inventory". Het betrof echter slechts 17 hypertensie-patiënten met een gemiddelde leeftijd van 63 jaar.

In het BGD-onderzoek treffen we geringe verschillen aan tussen hypertensieven en normotensieven op enkele schalen van de DMI. We constateren ook dat personen met een recent ontdekte hypertensie agressieve gevoelens meer naar buiten richten en minder gebruik maken van het defensiemechanisme 'rationalisatie' dan normotensieven, maar ook meer dan hypertensieven bij wie de bloeddruk reeds langer dan 2 jaar is verhoogd.

In het NS-onderzoek treffen we dit resultaat niet meer aan maar zoals eerder vermeld is in dit onderzoek een verkorte versie van de DMI gebruikt die mogelijk minder goed discrimineert.

\subsubsection{COPING-GEDRAG}

Een belangrijke plaats in het in hoofdstuk 4 beschreven onderzoeksmodel werd ingenomen door het copinggedrag: de wijze waarop men met aanpassing vereisende problemen omgaat. Het copinggedrag van iemand wordt enerzijds bepaald door de aard van de probleemsituatie en anderzijds door persoonlijkheidskenmerken en vroegere leerervaringen. We hebben speciaal voor ons onderzoek een lijst geconstrueerd, de UCL, die dit copinggedrag zou kunnen meten. Er is inmiddels ook door andere onderzoekers op grote schaal onderzoek verricht met deze schaal. Het instrument lijkt voldoende betrouwbaar en valide. Enkele vragen betreffende de criteriumvaliditeit blijven echter nog onbeantwoord. In het NS-onderzoek hebben we geen enkele significante relatie aangetroffen tussen de UCL-schalen en hypertensie.

\subsection{SUBTYPEN VAN HYPERTENSIEVEN}

Zowel psychologisch als fysiologisch gezien, is essentiele hypertensie een heterogene stoornis. Op fysiologisch gebied kunnen er volgens Obrist (1981) en Weiner (1979) verschillende pathogeneses verondersteld worden. Bij een groep hypertensieven treedt de verstoring primair op in het cardiale systeem en komt deze voornamelijk tot uiting in een systolische bloeddrukverhoging. In eerste instantie is er sprake yan een verhoogd hartminuutvolume en door aanpassing van het circulatiesysteem kunnen secundair allerlei structurele veranderingen optreden in de vaatwand waardoor ook na verloop van tijd de diastolische bloeddruk hoog blijft tengevolge de verhoogde perifere weerstand.

Bij een andere groep hypertensieven is er primair sprake van perifere 
wasoconstrictie waardoor met name een diastolische bloeddrukstijging aanwezig is.

Zouden aan deze verschillende pathogeneses ook andere psychologische factoren ten grondslag kunnen liggen?

Esler e.a. (1977) vergeleken hypertensieven waarbij in het bloedplasma een hoog renine-gehalte werd aangetrof fen, met een groep hypertensieven met een normaal renine-niveau en tenslotte met een groep normotensieven, op een aantal parameters van de sympatische activiteit. De hoog-renine groep vertoonde duidelijk hogere sympatische activiteit. Zij bleken tevens op psychologische vragenlijsten significant meer verdrongen vijandigheid te rapporteren dan de andere twee groepen. Hier is dus sprake van verschillende subtypen hypertensieven op fysiologisch en psychologisch gebied.

Van Schijndel (1986) wijst eveneens op de mogelijke fysiologische en psychologische heterogeniteit van essentiële hypertensie. Alvorens dit experimenteel aan te tonen voor hypertensie deed hij enkele onderzoeken met normotensieven. Zij werden in een prestatie-situatie gebracht (oplossen van anagrammen) waarbij cardiovasculaire reacties werden gemeten, waaronder systolische en diastolische bloeddruk, polsdruk en hartfrequentie en ook psychologische variabelen zoals type A gedrag, prestatiedrift en faalangst. Er werd aangetoond dat de respondenten onderscheiden konden worden op grond van de hemodynamische reactiepatronen. De cardiovasculaire reacties hielden verband met de moeilijkheidsgraad van de taak maar ook met de mate van faalangst van de respondenten. Een replicatie van het verband tussen faalangst, taakprestatie en cardiovasculaire reacties wordt momenteel door Van Schijndel (persoonlijke communicatie) bij hypertensieven onderzocht.

Het is dus zeer waarschijnlijk dat er verschillende pathogeneses zijn en dat hierbij verschillende psychologische kenmerken een rol kunnen spelen. In het BGD-onderzoek troffen we een bepaald copinggedrag aan bij hypertensieven bij wie pas recent de bloeddruk was verhoogd en dat we als volgt omschreven: een actief, agressief reactiepatroon van personen die recent veel aanpassing vereisende gebeurtenissen hebben meegemaakt en die hoog angstig zijn.

In het NS-onderzoek is geprobeerd via een clusteranalyse de groep hypertensieven op te splitsen op grond van scores op een aantal persoonlijkheidsvragenlijsten. Het resultaat bleek in eerste instantie een duidelijke bevestiging van de veronderstelling van het bestaan van in ieder geval twee subtypen: een groep kenmerkte zich door een hogere angst- en boosheidsdispositie, een externe beheersingsoriêntatie en het vertonen van een agressiever gedrag. De andere groep hypertensieven kenmerkte zich door een tegenovergesteld beeld namelijk door een lagere angstscore, een interne beheersingsoriëntatie en een lagere boosheidsdispositie. Een clusteranalyse uitgevoerd op alle normotensieve respondenten leverde echter nagenoeg 
eenzelfde beeld op. Er zal in toekomstig onderzoek moeten worden nagegaan waarom deze beide gedragspatronen bij sommige personen wel tot hypertensie kan leiden en bij andere daarentegen niet.

\subsection{WIJZIGING VAN HET ONDERZOEKSPARADIGMA}

We zijn dit onderzoek in eerste instantie begonnen om na te gaan welke persoonlijkheidskenmerken hypertensieven en normotensieven onderscheiden.

Deze vraagstelling is zowel op theoretisch als op praktisch gebied relevant. Theoretisch is het van belang om de betekenis nader te analyseren van een aantal persoonlijkheidskenmerken waarvan verondersteld wordt dat ze een rol spelen binnen de etiologie van essentielle hypertensie. Binnen de wetenschapplijke literatuur is geen eenstemmigheid over een zogenaamde 'hypertensie-persoonlijkheid', zo hebben we in hoofdstuk 2 uitvoerig toegelicht. De onderzoeken bleken in veel gevallen methodologische tekortkomingen te kennen en daarbij zijn ze moeilijk met ellkaar vergelijkbaar vanwege hantering van verschillende indelingscriteria voor hypertensie.

Het beantwoorden van bovenstaande vraagstelling kan echter ook een groot praktisch belang hebben. Kennis omtrent specifieke persoonlijkheidskenmerken van hypertensieven kan leiden tot een betere indicatiestelling voor psychotherapie. Daarbij komt dat de wenselijkheid om effectieve nietmedicamenteuze therapieën te ontwikkelen voor 'lichte' hypertensie steeds nadrukkelijker is te vernemen. Enkele oorzaken hiervan zijn terug te voeren tot de geweldige omvang van het probleem hypertensie, de consequenties voor de volksgezondheid en de weinig positieve resultaten van medicamenteuze behandeling van 'lichte' hypertensie (Medical Research Council, 1985).

Elders zijn we reeds dieper ingegaan op de te volgen strategie bij de behandeling van essentiële hypertensie (Schreurs en Godaert, 1978; Schreurs en Van de Willige, 1985). In dit getrapte behandelingsmodel worden allereerst algemene en breedwerkende adviezen gegeven met betrekking tot verandering van eet- en leefgewoonten waarvan verondersteld wordt dat ze een extra risico vormen voor cardiovasculaire complicaties. Enkele vormen van behandelingen die reeds een vaste plaats hebben ingenomen zijn: Een gerichte (gedragstherapeutische) aanpak van het lichaamsgewicht (Basler e.a., 1982), het terugdringen van het zoutgebruik, van sigaretten-roken en van alcoholconsumptie (Joint National Committee on detection, evaluation and treatment of high blood pressure, 1984). Terzijde merken we op dat er in het NS-onderzoek eveneens een sterke samenhang wordt geconstateerd tussen lichaamsgewicht en hypertensie.

Indien deze interventies van algemene aard, niet het gewenste resultaat opleveren, of niet in aanmerking komen, dan kunnen andere interventies 
worden overwogen. Enkele voorbeelden hiervan zijn behandelingen die meer aangrijpen op de veronderstelde verhoogde activiteit van het sympatische zenuwstelsel. Verlaging door middel van relaxatietraining en/of door biofeedback behoren in dit geval tot de mogelijkheden (Godaert, 1986).

Deze laatste technieken om de bloeddruk te verlagen hebben ons inziens pas kans van slagen indien ze ertoe leiden dat men effectiever (in de zin van probleemoplossend en emotie-regulerend) met aanpassing vereisende gebeurtenissen en levensomstandigheden leert om te gaan. Essentieel hierbij is dat men uit de aangeboden therapie, een gevarieerder copingrepertoire verwerft (zowel instrumenteel als intra-psychisch). Deze interventies zullen daarom ingebed moeten zijn in een ruimer therapeutisch kader (Schreurs en Godaert, 1978; Schreurs en Van de Willige, 1985). In dat geval is het noodzakelijk om een uitgebreid psychodiagnostisch onderzoek te verrichten. Dit onderzoek zal zich moeten richten op persoonlijkheidskenmerken, de sociale omstandigheden en de context waarin zich eventueel problemen voordoen. Een duidelijk inzicht in de betekenis van deze factoren met betrekking tot de etiologie en de instandhouding van essentiële hypertensie, zou derhalve zeer nuttig zijn.

Het onderzoeksmodel zoals we dat in hoofdstuk 4 hebben beschreven kan voorlopig slectits als een theoretisch model worden gezien. Alvorens dit model in zijn geheel te toetsen hebben wij allereerst de vraag gesteld of bij hypertensieven vaker bepaalde persoonlijkheidskenmerken voorkomen dan bij normotensieven. Middels de onderzoeken zoals beschreven in hoofdstuk 5 en hoofdstuk 6 kunnen wij stellen dat binnen onze onderzoekspopulaties dit niet duidelijk het geval is. We sluiten hiermee aan op de conclusie van een aantal vooraanstaande onderzoekers opgetekend na afloop van een conferentie omtrent de relatie persoonlijkheidskenmerken en essentiële hypertensie:

'....in light of previous research, it appears that further retrospective or cross-sectional analyses of personality traits and cardiovascular diseases would not be worthwhile...'(Ostfeld en Eaker, 1985).

We achten het van groot belang dat onderzoek wordt verricht waarbij rekening wordt gehouden met de heterogeniteit en de multicausaliteit van essentiële hypertensie. Centraal in dit onderzoek zou moeten zijn: de wijze waarop men met aanpassing vereisende situaties omgaat en de consequenties voor de bloeddruk op korte en lange termijn. Het onderzoeksmodel zoals we dat in hoofdstuk 4 hebben gepresenteerd kan weliswaar gehandhaafd worden, maar het is zeer de vraag of de huidige persoonlijkheidsvragenlijsten geschikt zijn om dit dynamische proces voldoende te kunnen registreren. Diverse constructeurs van psychologische vragenlijsten maken reeds een onderscheid in 'Trait-State'. De 'trait' staat yoor dispositionele eigenschappen waarmee wordt bedoeld een relatief stabiel kenmerk van de persoon. Bij de 'state' 
wordt nagegaan of de betreffende eigenschap van de persoon ook in een gegeven situatie van toepassing is. Er wordt dan meer rekening gehouden met de individuele inschatting van een situatie die het gedragspatroon all dan niet kan uitlokken.

Ook in de slotconclusie van het zojuist aangehaalde rapport naar aanleiding van de conferentie over persoonlijkheidskenmerken en hypertensie wordt door Siegel (in Ostfeld en Eaker, 1985) gesteld:

'.... rather than pursue further studies of personality as it has been conceptualized, it may prove more useful to try to assess global orientations of individuals. Global orientations, as used here, shares three characteristics with personality traits. A global orientation is internal to the individual, it is relatively enduring, and it is capable of directing behavior. Global orientations differ from personality traits in that they represent an individual's way of conceptualizing the world more than they represent an individual's way of being, they are a product of experience rather than an underlying disposition, and as a result, they are more mutable than personality traits.' (pag. 337).

Het uitgangspunt voor verder onderzoek blijft de premisse dat psychosociale factoren in samenhang met hereditaire factoren een rol spelen in de etiologie van essentiële hypertensie. Voor deze veronderstelling achten wij voldoende redenen aanwezig zoals we ook in hoofdstuk 2 hebben besproken. Om de relatie tussen bepaalde psychosociale factoren en vooral de invloed van persoonsgebonden factoren nauwkeurig aan te tonen dienen meer intraindividuele en longitudinale studies plaats te vinden. Hierbij kunnen de volgende assessment-procedures behulpzaam zijn:

\section{directe observatie}

Deze assessment procedure bestaat eruit dat enkele mensen gedurende langere tijd gevolgd worden tijdens hun copinggedrag met natuurlijk optredende stresssituaties. Gedragsmatige, cognitieve en fysiologische reacties dienen gelijktijdig geregistreerd te worden. Ambulante meetmethoden van cardiovasculaire reacties zijn hierbij noodzakelijk.

\section{analoge studies}

Een alternatief voor de directe observatiemethode is het aanbieden van gesimuleerde stresssituaties waarbij emotionele reacties worden opgeroepen. 


\section{LITERATUURLIJST}

Alexander F. Emotional factors in essential hypertension: presentation of a tentative hypothesis. Psychosomatic Medicine, 1939, wol 1, pp 173-179

Alexander F. Psychosomatic Medicine. Its principles and applications. New York, Norton, 1950 Andrien L. Cardiovascular effects of noise. Acta Medica Scandinavica, suppl nr 657, 1982

Andriessen J H T. Interne of externe beheersing. Ned T Y Psychologie, 1972, vol 27, pp 173-189

Appels A, Haes W de, Schuurman J Een test ter meting van thet "coronary-prone behaviour pattern" type A. Ned T Psychologie, 1979, vol 34, pp 181-188

Appels A. JAS- Jenkins Activity Survey: Handleiding, Swets en Zeillinger, Lisse, 1985

Arrindell W A, de Groot P M, Walburg J A. De schaal voor interpersoonlijk gedrag. Handleiding deel 1. Swets en Zeitlinger, Lisse, 1984

Ayman D. The personality type of patients with arteriolar essential hypertension. Am J Med Science, 1933, vol 186, pp 213

Baer P E, Collins F H, Bourianoff G G, Ketchel M F. Assessing personality factors in essential hypertension with a brief self-report instrument. Psychosomatic Medicine "1979, vol 41, pp $321-330$

Banahan B F, Sharpe T R, Baker J A, Liao W C, Smith M C. Hypertension and stress: a preventive approach. Jil Psychosomatic Research, 1979, vol 23, pp 69-75

Basler H D, Brinkmeier U, Buser $\mathrm{K}$, Haehn $\mathrm{K}$, Molders $\mathrm{R}$. Psychological group treatment of essential hypertension in general practice, $\mathrm{Br}$.Irl of Clinical Psychology, 1982, vol 21, pp 295-302

Bastelaer A van, Beers W van. Organisatiestress en de personeellsfunctionaris. Dissertatie Nijmegen. Swets \& Zeitlinger, Lisse, 1982

Baumann R, Ziprin, Godicke, Hartodt, Nauman Lauter. The influence of acute psychic stress situation on biochemical : and vegetative parameters of essential hypertension at the early stage of the disease. Psychotherapy and Psychosomaties, 1973, wol 22, pp 131-140

Bendig A W. The development of a short form of the Manifest Anxiety Scale. Journal Con Psychology, 1956, voll 20

Berglund $G$, Ander S, Linstrom B, Tibblin G. Personality and reporting of symptoms in normo. and hypertensive 50 year old males. Jil of Psychosomatic Research, 1975 , vol 19 , pp $139 / 145$

Berkman LF, Syme S L. Social networks, host resistance, and mortality: a nine-year follow-up study of Alameda county residents. Am J Epidemiology, 1979, wol 109, pp 186-204

Binger $C$ A, Ackerman N W, Cohn A E, Schroeder H A, Steele J M. Personality in arterial hypertension. In: Dunbar F (ed). Psychosomatic Med. Monographs, 1945, New York, Hoeber

Birkenhäger W H, de Leeuw P W. Hoge bloeddruk: wel of niet ingrijpen? Het gebied tussen 90 en $105 \mathrm{~mm} \mathrm{Hg}$ diastolische druk. Hart Bulletin, 1985, supplement vol $16, \mathrm{pp} 2-5$

Bout van den J. Verliesgebeurtenissen in attributie-theoretisch perspectief, Dissertatie Utrecht. Swets \& Zeitlinger, Lisse, 1986

Brod I e.a. Circulatory changes underlying blood pressure elevation during acute emotional stress (mental arithmetic) in normotensive and hypertensive subjects. Clin, $\mathrm{Scl}, 1959$, vol 18, pp 269-274

Brod $J$. Essential hypertension haemodynamic observations with a bearing on its pathogenesis. Lancet, 1960 , vol $2, \mathrm{pp} 773-778$ 
Brosschot J. Hoge bloeddruk en ontkenning van stress: een onderzoek met de verkorte wersie wan de Defense Mechanism Inventory. Intern rapport. Vakgroep Klinische Psychologie Utrecht, 1985

Burks N, Martin B. Everyday problems and life change events: ongoing versus acute sources of stress. Irl of Human Stress, 1985, voll 27

Brutten E 3 , Shoemaker D J. The modification of stuttering. Englewood Cliffs, Prentice-Hall, 1967

Carver C S, Coleman A E, Glass D C. The coronary-prone behavior pattern and the suppresion of fatique on a treadmill test. Int of Pers and Social Psycholgy, 1976, vol 33, pp 460-466

Cassel $J$. Hypertension and cardiovascular disease in migrants: a potential source of clues?. Int J Epidemiol., 1974, vol 3, pp 204-205

Chiang B N, Perlman $\mathbb{L}$ V, Epstein F H. Overweight and hypertension. Circulation, 1969, vol $39, \mathrm{pp} 403-421$

Cobb S, Rose R M. Hypertension, peptic ulcer and diabetes in air traffic controllers. JAMA, 1973, vol 224, pp489-492

Cobb S. Social support as a moderator of life stresses. Psychosomatic Medicine, 1976, wol 38, pp $300-314$

Cochrane R. Neuroticism and the discowery of high blood pressure. Irl of Psychosomatic Research, 1969, vol 13, pp 21-25

Cochrane R. Personality and essential hypertension. Comments on Contemporary Psychiatry, 1972, voll 1, pp 113-121

Cochrane $\mathbf{R}$. Hostility and neuroticism among unselected essential hypertensives. Irt Psychosomatic Research, 1973, vol 17, pp 215-218

Cohen-Kettenis P T, Dekking Y M. Cognitieve aspecten van sociale angst bij kinderen. Dissertatie Utrecht. Swets \& Zeitlinger, Lisse, 1980

Coleman T G. Regulatie van de bloeddruk en hypertensie. Hoofdstuk 7 In: Struyker Boudier H A J'. (red). Regulatie van de bloeddruk, Wetenschappelijke Uitgeverij Bunge, Utrecht, 1979

Cottington E M, Brock B M, House J S, Hawthorne V M. Psychosocial factors and blood pressure in the Michigan Statewide Blood pressure Survey. Am J Epidemiology, 1985, wol 121. pp $515-529$

Cowan $\mathrm{R}_{\mathrm{b}}$ Sokolow $\mathrm{M}, \mathrm{P}$ erloff $\mathrm{D}$. The Remler ambulatory blood pressure recording system. Accuracy and reliability. Br. Heart $\mathrm{Jrl}, 1980$, vol 43, 715-716

Dahl L K, Heine $M$, Tassinari L F, Effects of chronic excess salt ingestion: Evidence that genetic factors play an important role in susceptibility to experimental hypertension. Jrl of Experimental Medicine; 1962, vol 115, pp 1173-1190

Davies M. Blood pressure and personality. Jal Psychosomatic Research, 1970, wl 14, pp 89-104

Dembrosk T T M; McDougall J M, Shields J L. Physiologic reactions to social challenge in persons evidencing the type A coronary-prone behavior pattern. Jrl of Human Stress, 1977, sept. pp $2-9$

Diamond $\mathrm{E} L$. The role of anger and hostility in essential hypertension and coronary heart disease. Psychological Bulletin, 1982, vol 92, pp 410-433

Dimsdale J E, Pierce C, Schoenfeld D, Brown A, Zusman R, Graham R. Suppressed anger and blood pressure: the effects of race, sex, social class, obesity, and age. Psychosomatic Medicine, 1986, wol 48, pp 430-435

Dirken J. Arbeid en stress. Groningen, Wolters, 1967

Ditto B. Parental history of essential hypertension, active coping, and cardiovascular reactivity. Psychophysiology, 1986, vol 23, pp 62-69 
Dohrenwend B $\mathbf{S}_{3}$. Dohrenwend B P. Stressful life events. Their nature and effects, New York, Wiley and Sons, 1974

Dressler W W. Blood pressure, relative weight, and psychosocial resources. Psychosomatic Medicine, 1983 , pp 527,536

Drummond P D. Personality traits in young males at risk for hypertension. Jn Psychosomatic Research, 1982, voll 26, pp 585-589

Drunkenmölle C. Psychologische Untersuchungen bei der Essentiellen Hypertonie. Z Gesamt Inn Med, 1976, vol 31, pp 289-291

Dyer A R Stamler J, Shekelle R B. The relationship of education to blood pressure: findings on 40000 employed Chicagoans. Circulation, 1976, vol 54, pp $987-992$

Eide R. The relationship of psychosocial factors to arterial blood pressure: an epidemiological study in Western Norway. Paper presented at the World Congres of the Psychosomatic Society, Noordwijkerhout, 1982

Eiff A W von. Pathophysiologie und Aetiologie der Essentiellen Hypertonie. Munch. Med. Wschr, 1984, vol 126

Eijk J TH H van. Levensgebeurtenissen en ziekte. Dissertatie Nijmegen, 1979

Eliasson K, Hjemdahl K T. Circulatory and sympatho-adrenal responses to stress in borderline and established hypertension. Jrl of Hypertension, 1983, wol 1, pp 131-139

Engel B T, Bickford A F. Response-specificity, stimulus-response and individual-response specificity in essential hypertension. Archives of General Psychiatry, 1961, vol 5, pp 478-489

Esler M, Julius S, Zweifler A, Randall O, Harburg E, Gardiner $\mathrm{H}$, DeQuattro V. Mild high-renin essential hypertension: Neurogenic human hypertension? The New Engl Jrl of Med, 1977 , vol 296, pp $405-411$

Eyer J. Hypertension as a disease of modern society. Int Jrl of Health Serwices, 1975 , vol 5, pp $539-588$

Eysenck H J, Eysenck S G B. Manual of the Eysenck Personality Inwentory, London, University of London Press, 1964

Falkner B, Kushner $\mathbf{H}_{\text {, }}$ Onesti $\mathrm{G}$, Angelakos E T. Cardiovascular characteristics in adolescents who develop essential hypertension. Hypertension, 198॥, vol 3, pp 521-527

Feén J A E van der. Hypertensie: een uitdaging voor de huisarts. Dissertatie, Rotterdam, 1977

Feinleib M. Genetics and familial aggregation of blood presssure. pp 35-48. In: Onesti $G$, Klint C R (eds). Hypertension. Determinants, complications, and intervention; Orune and Stratton, New York, 1979

Folkman S, Lazarus R S. An analysis of coping in a middle-aged community sample. Jirl of Health and Social Behavior, 1980, vol 21, pp 219-239

Folkow B, Rubinstein E H. Cardiovascular effects of acte and chronic stimulation of the hypothalamic defense area in the rat. Acta Physiologic Scandinavia, 1966, wol 68, pp 48-57

Folkow B, Goethberg $G$, Lundin $S$, Ricksten $S$ E. Structural 'resetting' of the renal wascular' bed in spontaneously hypertensive rats (SHR). Acta Physiologica Scandinavia, 1977, vol 100, pp 270-272

Folkow B. Physiological aspects of primary hypertension. Physiol Rew, 1982, wol 62, pp 347-503

French J R, Caplan R D. Organizational stress and individual strain. In: Marrow A $\mathbf{J}$ (ed). The failure of stress. New York, Amacom, 1972

Friedman G D, Klatsky A L. Siegelaub A B. Aleohol, tabacco and hypertension. Hypertension, 1982, suppl III, $4 \mathrm{nr}$ 5: III-143-150 
Friedman R, Dahl $\mathrm{L} \mathrm{K}$. The effect of chronic conflict on the blood pressure of rats with genetic susceptibility to experimental hypertension. Psychosomatic Medicine, 1975, vol 37, pp $402-416$

Friedman R, Iwai J. Genetic predisposition and stress-induced hypertension. Science, 1976, vol 193, pp $161-162$

Garamon G L, Schwartz R M. Type A behavior pattern and compulsive personality: toward a psychodynamic-behavioral integration. Clinical Psychology Review, 1986, vol 6, pp $311-336$

Gentry $W D$, Chesney $A, P$, Gary $H E$, Hall $\mathbb{R} P$, Harburg $E$. Habitual anger-coping styles: I.Effect on mean blood pressure and risk for essential hypertension. Psychosomatic Medicine, 1982, vol 44, pp 195-202

Gentry W. Relationship of anger-coping styles and blood pressure among black Americans. In: Chesney $M A$, Rosenman $\mathrm{R} H$ (eds). Anger and hostility in cardiovascular and behavioral disorders, Hemisphere, New York, 1985

Gezondheidsraad. Advies inzake Hypertensie, 's Gravenhage: Staatsdrukkerij, 1983

Glass D C. Behavior patterns, stress, and coronary disease. Wiley and Sons, New York, 1977

Gleser G L, Ihilevich D. An objective instrument for measuring defense mechanisms. Jrl of Consulting Clinical Psychology, 1969, vol 33

Godaert $\mathrm{G}$. Hoge bloeddruk en relaxatie. Klinisch psychologische en psychofysiologische aspecten. Dissertatie Amsterdam, 1986,

Graham D T, Kabler J D, Graham F. Psychological response to the suggestion of attitudes specific for hives and hypertension. Psychosomatic Medicine, 1962, vol 24, pp 159-169

Graham D T. Psychosomatic Medicine. In: Greenfield N S, Sternbach R A. Handbook of Psychophysiology. New York, Holt, Rinehart en Winston, 1972

Graham J D P. High blood pressure after battle. Lancet, 1945, vol 1, pp 239-242.

Gressel G E, Shobe F O, Saslow G, Dubois P H, Schroeder H A. Personality factors in arterial hypertension. JAMA, 1949, vol 140, pp 265-272

Groen $1 \mathrm{~J}$, Reisel $\mathrm{J}$. Constitutionele en emotionele factoren in de aetiologie van de essentiele hypertensie. Ned Tijds v Geneeskunde, 1948, vol 92, pp 3714-3723

Groen J J, Hansen $B$, Hermann, JM, Schafer $H$, Schmidt T $H$, Selbmann $K_{\text {, }}$, Uexkull T von, Weckman P. Effects of experimental emotional stress and physical exercise on the circulation in hypertensive patients and control subjects. Jrl Psychosomatic Research, 1982, vol 26, pp 141-154

Groot de $\mathbb{P}$, Walburg J. Constructie van cen assertiviteitsschaal. Interne publicatie, vakgroep klinische psychologie Leiden, 1977

Grossman P. Respiration, stress, and cardiovascular function. Psychophysiology, 1983, vol 20, pp 284-300

Gutman $M C$, Benson $H$. Interaction of environmental factors and systemic arterial blood pressure. Medicine, 1971 , vol $50, \mathrm{pp} 543553$

Guyton A C, Coleman T $C_{y}$ Cowley A W, Manning R D; Norman R A, Ferguson J D. A systems analysis approach to understanding long range arterial blood pressure control and hypertension. Circulation, 1974, wol 35, pp 159-176

Hall fens R J $G$. Locus of control. Beheersingsorientatie in telatie tot ziekte en gezondheidsgedrag. Dissertatie RU Limburg, 1985

Hambling J. Emotions and symptoms of essential hypertension. Br Jil of Med Psych, 1951, vol 24, pp 242

Handkìs R E; Munz D C. Essential hypertension and self-disclosure. Jrl of Clinical Psychology, 1978, vol 34, pp 870-875 
Harburg E, Erfurt I, Hawenstein L S, Chape C, Schull WJ, Schork MA. Socio-ecological stress, suppressed hostility, skin color, and black-white male blood pressure: Detroit. Psychosomatic Medicine, 1973, 10ll 35, pp 276-296

Harburg E, Blakelock E H, Roeper P J. Resentful and reflective coping with arbitrary authority and blood pressure: Detroit. Psychosomatic Medicine, 1979, vol 41, pp 189-202

Harlan W R, Osborne R K, Graybiel A. Prognostic value of the cold pressor test and the basal blood pressure. An J Cardioll, 1964, woll 13, pp 683-695

Harrell J P. Psychological factors and hypertension: a status report. Psychological Bulletin, 1980, vol 87, pp 482-501

Harris R E, Sokolow M, Carpenter L G, Freedman M, Hunt S P. Response to psychological stress in persons who are potentially hypertensive. Circulation, 1953, vol 7, pp 874-879

Hastrup J L, Light K C, Obrist P A. Parental hypertension and cardiovascular response to stress in healthy young aduits. Psychophysiology, 1982, vol 19, pp 615-622

Hawkins N G, Davies R, Holmes T H. Evidence of psychosocial factors in the development of pulmonary tuberculosis. Am $\mathbb{R e v}$ Tuberc Pulmon Dis, 1957 , vol 75, pp 768-780

Haynes R B, Sackett D L, Taylor D, Gibson E S, Johnson A L. Increased absenteeism from work after detection and labeling of hypertensive patients. N Engl J Med, 1978, wol 299, pp $741-744$

Henry J $\mathbf{P}$, Meehan J $\mathbf{P}$. Stephens $\mathbf{P}$ M. The use of psychosocial stimuli to induce prolonged systolic hypertension in mice. Psychosomatic Medicine, 1967, vol 29, pp 408-432

Henry I P, Stephens P M, Santistiban G A. A model of psychosocial hypertension showing reversibility and progression of cardiovascular complications. Circulation Research, 1975, vol 36, pp 156-164

Henry J P, Stephens P M. Stress, Health and the social environment, Springer Verlag, Berlin, 1977

Hermans H J M. PMT-Prestatie Motivatie test; handleiding. Swets \& Zeidinger, Amsterdam, 1976.

Hinkle L E. Th concept of 'stress' in the biological and social sciences. Sci. Med. \& Man., 1973,

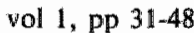

Hofman A, Valkenburg H A. Een epidemiologisch onderzoek naar risico-indicatoren voor harten vaatziekten (EPOZ). 1I. Voorkomen, opsporing en behandeling van hypertensie in een open bevolking. Ned T Geneeskunde, 1980, vol 124, pp 189-195

Hofman A, Grobbee D E, Valkenburg H A. Een epidemiologisch onderzoek raiar het verband tussen alcohol en bloeddruk, Ned Tijdschr Geneeskunde, 1985, vol 129, pp 639-641.

Hokanson $3 \mathrm{E}$, Shetler $\mathrm{S}$. The effect of overt aggression on psychological tension level. Irll of Abnormal and Social Psychology, 1961, vol 63, pp 446-448

Hokanson $\mathrm{J} \mathrm{E}_{\mathrm{y}}$ Burgess $\mathrm{M}$. The effects of three types of aggression on vascular processes. Jrl of Abnormal and Social Psychol, 1962, vol 64, pp 446-449

Hokanson J E, Burgess M, Cohen M E. Effects of displaced aggression on systolic blood pressure. Jrl of Abnormal and Social Psychology, 1963, vol 67, pp 214

Hokanson $3 \mathrm{~F}$, DeGood D E, Forrest M S, Brittain T M. Avallability of avoidance behaviours in modulating vascular stress responses. J Pers Soc Psych, 1971, vol 19, pp 60-68

Holme I, e.a. Coronary risk factors and socioeconomic status. Lancet, dec, 1976, pp 1396-1397

Holme I, e.a. Coronary risk factors in various occupational groups: the Oslo study. Br Jrl Prev Soc Med, 1977, wol 31, pp 96-100

Holmes T H, Rahe R H. The social readjustment rating scale Irl of Psychosomatic Research, 1967, vol 11, pp 213-218 
Holmes $T H$, Masuda $M$. Life change and illness susceptibility. In: Dohrenwend e.a (eds) Stressful life events: their nature and effects. John Wiley and Sons, Newe York, 1974

Holroyd $\mathrm{K} \mathrm{A}$, Gorkin $\mathrm{L}$. Young adults at risk for hypertension: effects of family history and anger management in determining responses to interpersonal conflict. Irl Psychosonatic Research, 1983, wol 27 , pp 131-138

Horowit: $\mathrm{M}$, Schaefer $C_{\text {, Looney }}$. Life events scaling for recency of experiences. pp 125-133. In: Thomas C. Life stress and illness. Springfield, 1974

Jenkins D, Rosenman R H, Friedman M. Development of an objective psychological test for the determination of the coronary-prone behavior pattern in employed men. Jrl of Chronic Disease, 1967, vol 20, pp 371-379

Jenkins C D. The coronary-prone personality. In: Gentry W D e.a. (eds). Psychological and myocardial infarction and coronary care. Mosby Comp, St Louis, 1979

Jenkins $C D$, Somervell $P D$, Hames $C G$. Does blood pressure usually rise with age? .... or with stress?. II of Human Stress, 1983 , vol 9, pp 4-12

Jenkins C D, Hurst M W, Rose R M, Anderson L, Kreger B E. Biomedical and psychosocial predictors of hypertension in air-traffic controllers: Ch $17 \mathrm{In}$ : Spielberger C D, Sarason $I$ G, Defares P B (eds). Stress and anxiety vol 9. Hemisphere, 1984

Jern S. Psychological and hemodynamic factors in borderline hypertension. Acta Med Scand (suppl), 1984 , pp 662

Joint National Committee on detection, evaluation and treatment of high blood pressure. Archives General Psychiatry, 1984, yol 144, pp 1045-1057

Joossens IV. De preventie van cardiovasculaire aandoeningen. Hartbulletin, 1980, vol 11, pp $121-124$

Jorgenson R S, Houston B K. Family history of hypertension, gender, and cardiovascular reactivity and stereotypy during stress. I Behavioral Medicine, 1981 , vol 4, pp 175

Jost $H$ C e.a. Studies in hypertension II. Central and autonomic nervous system reactions of hypertensive individuals to simple physical and psychological stress situations. J Nerv Ment Disease, 1952, voll 115 , pp 152

Julius $\mathrm{S}$, Conway $\mathrm{J}$. Hemodynamic studies in patients with borderline blood pressure elevation. Circulation, 1968, vol 38 , pp 282-288

Julius S, Schork M A. Predictors in hypertension. In: Perry H, Smith W. Mild hypertension: to treat of not to trent. Annals of the New York Academy of Sciences, 1978, vol 304, pp 38-52

Julius S, Esler M D. Autonomic nerwows cardiovascular regulation in borderline hypertension. Am Inl Cardiology, 1975, vol 36, pp 685-696

Julius S, Cottier C. Behavior and hypertemsion, Ch 17 In: Dembroski T M, Schmidt T H, Blumchen $\mathrm{G}$ (eds). Biobehavioral Bases of coronary heart disease, Karger, Basel, 1983

Juluus S, Schneider R H, Egan B. Suppressed anger in hypertension: facts and problems. In: Chesney M A, Rosenman R H. (eds) Anger and hostility in cardiovascular and behavioral disorders, New York, Hemisphere, 1985

Juni S. The composite measure of the Defense Mechanism Inventory, Irl of Research in Personality, 1982 , vol 16, pp 193-200

Kagan A R, Levi L. Haalth and environment-psychosocial stimulis a review, Soc Sci Med, 1974, vol 8, pp 225-241

Kalimo R. Stress in work. Scand J Work Environment and Health, 1980, vol 6. suppl 3, pp 343-373

Kalis B L, Harris R E. Sokolow M, Carpenter L G. Response to psychological stress in patients with essential hypertension. Am Heart Journal, 1957, wol 53, pp 572-578 
Kamnel W B, Drawber T R. Hypertensive cardiovaseular disease: The Franingham study. pp 523 In: Onesti G, Kim K E, Meyer I M (eds).Hypertension: Mechanisms and management, 1973, New York, Grune and Stratton

Kannel W B, Kreger B E. Recent Framingham findings on morbidity and mortality in hypertension. pp 103-127 In: Arntszenius A C Durning A J, Snellen H A (eds). Blood pressure measurement and systemic hypertension, Breda, Medical World Press, 1981

Kaplan N M. Stress, the sympathetic nerwous system and hypertension. Jul of Human Stress, 1978, vol 4, pp 29-34

Kaplan NM. The control of hypertension, a therapeutic breakthrough. Am Sci, 1980, vol 68, pp $537-5.45$

Kasl $\mathrm{V}$, Cobb S. Blood pressure changes in men undergoing job loss: a preliminary report. Psychosomatic Medicine, 1970, vol 32, pp 19-38

Kasl S V, Cobb S. The experience of losing a job: some effects on cardiovascular functioning. Psychotherapy and Psychosomatics, 1980, vol 34, pp 88-110:

Katzenstein A, Kriegel E, Gaefke J. Erfolg Untersuchung bei einer komplexen Psychotherapie Essentielle Hypertonie, Psychiatric Neurol Med Psychol, 1974, vol 26, pp 731-737

Keane T M, Martin J, Berler E S, Wooten L S, Fleece E $L_{*}$, Williams J G. Are hypertensives less assertive? A controlled evaluation. Jrl Consulting \& Clinical Psychology, 1982, vol 50, pp 499-508

Kleber R J. Stressbenaderingen in de psychologie. Van Loghum Slaterus, Deventer, 1982

Kleber $\mathrm{R}$ J. Traumatische ervaringen, gevolgen en verwerking. Dissertatie, Swets \& Zeitlinger, Lisse, 1986

Kobasa S C. Maddi S R, Zola M. A. Type A and hardiness. Jn Behavioral Medicine, 1983, vol 6. pp $41-51$

Koolhaas $\sqrt{ }$, Schuurman $T$, Fokkema D S. Social behavior of rats as a model for the psychophysiology of hypertension, In: Dembroski $T M$, Schmidt $T H$, Blümchen $G$. Biobehavioral bases of coronary heart disease Karger "Basel, 1983

Kuilenburg $\mathbf{K}$ van. Een vergelijking tussen de vragenlijsi- en de interviewmethode bij het meten van ingrijpende wijzigingen in levensomstandigheden. Doctoraalscriptie Vakgroep Klinische Psychologie, juni 1980

Lal $\mathbb{N}_{\text {, Ahuja }} \mathbf{R}$ C. Madhukar. Life events in hypertensive patients. Jrl of Psychosomatic Research, 1982, vol 26, pp $4411-447$

Lacey B C, Lacey J I. Studies of heart rate and other bodily processes in sensorimotor behavior. In: Obrist P A e.a. (eds), Cardiovascular psychophysiology, Aldine, Chicago, 1974

Lawler J E, Cox R H. The borderline hypertensive rat (BHR): a new model for the study of environmental factors in the development of hypertension. Pavlovian J Biol Sci; 1985, sept, pp $101-115$

Lazarus R S. Psychological stress and the coping process. McGraw-Hill, New York, 1966

Lazarus R S. The stress and coping paradigm. In: Eisdorfer $C$, Kleinman $\mathbf{A}$, Maxim $\mathbf{P}$ (eds). Theoretical basis for the psychopathology, Spectrum, New York, 1980

Lazarus R S, Cohen J B, Folkman S, Kanver A, Schaefer C. Psychological stress and adaptation. Some unresolved issues. pp 90-117 In: Sellye H (ed). Selye's guide to stress research, wol 1, Van Nostrand Reinhold, New York, 1980

Leficourt H M. Locus of controll: current trends in theory and research. Hillsdale, New York, Erlbaum, 1976

Light $\mathrm{K}$ C. Cardiovascular responses to effortful active coping: implications for the role of stress in hypertension development. Psychophysiology, 1981, vol 18, pp 216-225 
Linden W, Feuerstein M. Essential hypertension and social coping behavior: experimental findings. Irl of Human Stress, 1983, sept. pp 22-31

Linden W. Psychological perspectives of essential hypertension: etiology, maintenance and treatment, Karger, Basel, 1984

Loo K J M van de. De klinische psychologie in dienst van de problematiek van de essentiele

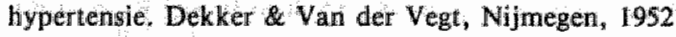

Luteijn $\mathrm{F}$, Starren I, Dijk H wan. Hardleiding bij de Nederlandse Persoonlijkheidsvragenlijst (NPV). Swets en Zeitlinger, Amsterdam, $\$ 975$

Lynch J L, Long $J \mathrm{M}$, Thomas $\mathrm{S} A$, Mallinow $\mathrm{K} \mathrm{L}$, Kateher $\mathrm{A} H$. The effect of talking on the blood pressure of hypertensive and normotensive individuals. Psychosomatic Medicine, 1981 , vol 43 , pp 25

Mann A H. The psychological aspects of essential hypertension. Irl of Psychosomatic Research, 1986 , vol 30, pp 527-541

Manning JW. Central integration of cardiovascular control. $\mathrm{pp} 35-54 \mathrm{ln}$ : Orlebeke $\mathrm{J} F$, Mulder G, Doornen LIP van (eds). Psychophysiology of cardiovascular control, Plenum, New York, 1985

Manuck S B. Harvey A $H_{n}$ Lechleiter S L, Neal K S. Effects of coping on blood pressure responises to threat of awersive stimulation. Psychophysiology, 1978, vol 15, pp 544-549

Manuck S B, Proietti J M. Parental hypertension and cardiovascular response to cognitive and isometric challenge. Psychophysiology, 1982, vol 19, pp $481-489$

Manuck S B, Morrison A S. Bellack A S. Behavioral factors in hypertension: cardiovascular responsibility, anger, and social competence. pp 149-172 In: Chesney e. (eds). Anger, hostility and behavioral medicine. Hemisphere, New York, 1984

Marcelissen F, Gangmakers van het stressproces. De rol van type-A gedrag en sociale ondersteuning bij het stressproces in de werksituatie. NIPG, Leiden, 1987

Marmot M G. Geography of blood pressure and hypertension. Br Med Bull, 1984, vol 40, pp $380-386$

Matthews K A, Brunson B I. Allocation of attention and the type A coronary-prone behavior pattern. Jrl of Personality and Social Psychology, 1979, vol 37, pp 2081-2090

Medical Research Council Working Party. MRC trial of mild hypertension, principal results. Brit Med Irl, 1985, vol 291, pp 97-104

Meyer E, Derogatis L R, Miller $M$, Reading $A$. Hypertension and psychological distress. Psychosomatics, 1977 , vol 19, pp 3

Miasnikov A L* The significance of thigher nervous system activity in the pathogenesis of hypertensive disease. pp 152162 In: Cort $1 H$, Fenel $V$, Heil $Z$, Jirka I. The pathogenesis of essential hypertension, State Medical Publishing House, Prague; 1961

Miller N E, Dworkin B R. Critical issues in therapeutic applications of biofeedback. In Schwartz G E, Beatty (eds). Biofeedback. Academic Press, New York, 1977

Miller N E. Effects of learning on physical symptoms produced by psychological stress. In: Selye $H$ (ed). Selye's guide to stress research, vol 1, Van Nostrand, New York, 1980

Millet R A, Shekelle R B. Blood pressure in 10-th grade students. Cireulation, 1976; vol 54, pp 9931000

Minsky P J. High blood pressure and interpersonal 'disengagement' a study of maladaptive coping styles and ameliorative treatment. Loyola University of Chicago Diss Abstr Int, 1978, ni 38, pp 11-13

Monk M.Psyehological status and hypertension. Am J Epidemiology, 1980, vol 112, pp 200-208 
Montfrans $G$ van. Continuous ambulatory blood pressure iregistration in uncomplicated lyypertension- Cuff responders and blood pressure variability, Dissertatie Universiteht van Amsterdam, 1984

Moor W de, Orlemans J W G. Inleiding tot de gedragstherapie. Van Loghum Slaterws, Deventer, 1972

Naditch M P. Locus of control, relative discontent and hypertension. Social psychiatry, 1974, vol 9, pp 111-117

Nution J, Beuten B. Manifeste-angstschaal van Taylor met verkorte Bendig-worm en de A-factor wan Welsh. Studia Psychologica, Leuven, 1977

Obrist $\mathrm{P}$ A. The cardiovascular-behavioral interaction as it appears today. Psychophysiology, 1976, vol 13, pp 95-107

Obrist PA, e.a. Blood pressure control mechanisms and stress; implications for the etiology of hypertension. In: Onesti, Klimt (eds). Hypertension: Physiopathology and treatment. McGraw Hill, New York, 1979

Obrist P A. Cardiovascular psychophysiology: A perspective. Plenum Press, New York, 1981

Onesti G, Horan M J, Padgett N E, Kennedy H L. Ambulatory blood pressure monitoring: recent advances and clinical applications. Am Heart Journal, 1981, vol 101, 843-848

Ormel J. Moeite met leven of een moeilijk leven. Dissertatie Groningen, Konstapel, 1980

Ostfeld A M, Eaker E D. Measuring psychosocial varimbles in epidemiologic studies of cardiovascular disease. Proceedings of a workshop. NIH publications no 85-2270, 1985

Parkes K R. Locus of contol, cognitive apprailsal, and coping in stressful episodes. Jrl Pers Soc Psychology, 1984, vol 46, pp 655-668

Passchier $\mathrm{J}$, Verhage $\mathrm{F}$. The defense mechanism inventory: preliminary findings on reliability and validity of the dutch translation. Gedrag en Gezondheid, 1986, vol 1.4, pp 119-125

Paykel E S, Brinoff A, Uhlenhuth E H. Scaling of life events. Archives General Psychiatry, 1971, vol 25, pp 340-347

Paykel E S. Methodological aspects of life events research. Irl of Psychosomatic Research, 1983, voll 27 , pp $341-352$

Pearlin $L$, Schooler K. The structure of coping. Jrl of Health and Sacial Behaviour, 1978, wal 19, pp 2-21

Perloff $D$, Sokolow $M$, Cowan $R$. The prognostic value of ambulatory blood pressure. JAMA, 1983, wol 249, pp $2792-2798$

Phares E J Locus of control in personality Morristown, New York, General learning, 1976

Pickering, Sir George. Hypertension. Definitions, natural histories and consequences. pp 3-30 In: Laragh J H (ed). Hypertension manual-mechanisms, methods, management. Dum-Domnely

New, York, 1973

Pickering $T$, Harshfield $G$ A, Kleinert $H$ D, Blank S, Laragh J H. Blood pressure during normal daily activities, sleep and exercise. JAMA, 1982, vol 247, pp 992-996

Pilowsky Ix Spalding D, Korner $\mathbf{P} \mathbb{I}$. Hypertension and personality. Psychosomatic Medicine, 1973, vol 35, pp 50-56

Pittner M S, Houston B K. Response to stress, cognitive coping strategies and the type A behavior pattern. Irl Pers Soc Psychology, 1980, vol 39, pp 147-157

Platt R. The nature of essential hypertension. Lancet, 1959 , vol 2, pp $55-57$

Ploeg H M van der, Defares P B, Spielberger C D. Handleiding bij de Zelf-Beoordelings Vragenlijst, ZBV. Een Nederlandstalige bewerking van de Spielberger State-Traít Anxiety Inventory, STAI-DY, Swets \& Zeitlinger, Lisse, 1980 
Ploeg H M van der, Defares P $B_{n}$ Spielberger C D. Handleiding bij de Zelf-Analyse Vragenlijst,

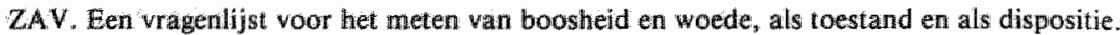
Een Nederllandstalige bewerking van de Spielberger State-Trail Anger Scale, Swets \& Zeitlinger, Liste, 1982

$\mathrm{P} \|_{\text {oeg }} \mathrm{H} \mathrm{M}$ van der, Buuren $\mathrm{E} \mathrm{T}$, Brummelen $\mathbb{P}$ var. The role of anger in hypertension. Psychother. Psychosom. , 1985, vol 43, pp 186-193

Plutchik R. Kellerman H, Conte H R. A structural theory of ego defenses and emotions. In: Izard $C$ (ed). Emotions in personality and psychopathology, Plenum, New York, 1979

Pooling Project Research Group. Relation of blood pressure, serum cholesterol, smoking habit, relative weight and $\mathrm{ECG}$ abnormalities to incidence of major coronary ewents: Final report of the Pooling Project. J Chronic Disease, 1978, wol 31, pp 201-306

Price $\mathrm{V}$ A. Type-A belhavior pattern; a model for research and practice. New York, Academic Press, 1982

Prins A. Mensen met verhoogde bloeddruk en hun bereidheid deze te laten controleren; een bevolkingsonderzoek in Krimpen aan de IJssel. Ned T v geneeskunde, 1979, vol 24, pp 723-726

Rahe R. H. The pathway between subjects recent life changes and their near-future illness reports. In: Dohrenwend e.a (eds). Stressful life ewents. Wiley and Sons, New York, 1974

Rahe R H. Life change measurement clarification. Psychosomatic Medicine, 1978, wol 40 , pp 95.98

Richter Heinrich $\mathbb{E}$, Lauter $\mathbf{J}$. A psychophysiological test as a diagnostic tool with essential hypertensives. Psychotherapy Psychosomatics, 1969, vol 17, pp 153-168

Robbins $\mathbf{P} R$, Tanck $H \mathrm{H}$. A factor analysis of coping behaviors. Jrl of Clinical Psychology, 1978, vol 34, pp 379-380

Robinson J O. A study of neuroticism and casual arterial blood pressure. Br J Soc Clin Psychol, 1962, vol 2, pp 56-64

Robinson J O. Symptoms and personality in the diagnosis of physical illness. J Prev Med Sociol, 1968 , vol 12, pp 23

Rodenburg $N$. De macht van de deskundige: een onderzoek over machteloosheid en deskundigheid. Van Gorcum, Assen, 1974

Rosenman $R H$, Friedman $M_{3}$ Strauss $R$ et al. A predictive study of CHD- the Western Collaborative Group Study. JAMA, 1964, vol 15, pp 113-124

Rosenman R H e.a. Western Collaborative Group Study: a follow-up experience of two years. JAMA, 1966, vol 195, pp 86-95

Rotter J B. Generalized expectancies for internal versus external control of reinforcement. Psychological Monographs, 1966, wol 80

Ruskin A, Beard $O$ W, Schaffer R L. Blast hypertension: elewated arterial pressure in victims of the Texas City Disaster. Am Jrl Med, 1948, vol 4, pp 228-236

Sainsbury P. Neuroticism and hypertension in an out-patient population. Jrl Psychosom Res, 1964, vol 8, pp 235-238

Sanderman $R$, Ormel $H$. De Utrechtse Coping Lijst (UCL). Betrouwbaarheid en validiteitsaspecten (in woorbereiding)

Sannerstedt $\mathbf{R}$, Julius S. Systemic haemodynamics in borderline arterial hypertension: Response to static exercise before and under the influence of propanolol. Cardiovascular Res, 1972, voll $6, \mathrm{pp} 398-403$

Santonastaso $\mathrm{P}$, Canton $\mathrm{G}$, Ambrosio G B, Zamboni $S$. Hypertension and neuroticism. Psychother. Psychosom., 1984, vol 41, pp 7-11 
Sapira J D, Scheib E T, Moriarty R, Shapira A P. Differences in perception between hypertensive and mormotensive populations. Psychosomatic Medicine, $197 \mathrm{I}_{\mathrm{o}}$ wol 33, pp 239-250

Sarason I G, Levine H M, Basham R B, Sarason B R. Assessing the social support: the social support questionnaire. Irl of Pers and Soc Psychology, 1983, vol 44, pp 127-139

Saslow $G$, Gressel $\mathrm{G}$ C, Shobe F O, Dubois P H, Schroeder H A. Possible factors in arterial hypertension. Psychosomatic Medicine, 1950, wol 12, pp 292-302

Saul L J. Hostility in cases of essential hypertension. Psychosomatic Medicine, 1939, vol 1, pp 153-216

Schachter J. Pain, fear, and anger in hypertensives and normotensixes. Psychosomatic Medicine, 1957, vol 19

Schaefer $C$, Coyne $J$ C, Lazarus $R$. The health-related functions of social support. Irl of Behavioral Medicine; 1981, vol 4, pp 381-406

Schalling D. Anxiety, unexpressed anger, and lack of assertiveness. pp 241-251 ln: Spielberger C D, Sarason I G, Defares P B (eds). Stress and anxiety vol 9, Hemisphere, 1984

Schalling D, Swensson J. Blood pressure and personality. Personality and Individual Differences, 1984, wol 5, pp 41-51

Schijndel M W A M van. Cardiovascular dynamics: a psycho-physiological study. Dissertatie Nijmegen, Swets en Zeitlinger, Lisse, 1986

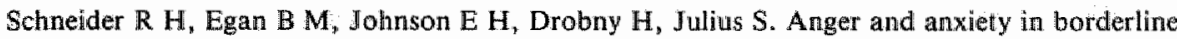
hypertension. Psychosomatic Medicine, 1986, vol 48, pp 242-248

Schneiderman N. Behavior, autonomic function and animal models of cardiovascular pathology. pp 304-364. In: Dembroski T M e.a. (eds). Biobehavioral bases of coronary heart diseases. Karger, Basel, 1983

Schreurs P J G, Son M J M van, Godaert G. Sociale angst ent hypertensie: Rapportage aan de Hartstichting betreffende subsidie 1976. Intern rapport Klinische Psychologie Utrecht, 1976

Schreurs P J G, Corpeleijn F, Een onderzoek maar hoge bloeddruk als psychosomatisch verschijnsel: tocus of control en hypertensie. Intern rapport Klinische $\mathbb{P}_{\text {sychologie Uttrecht, }}$ 1977

Schreurs $\mathbf{P}$ J G, Godaert $G$. Hoge bloeddruk: medicijnen helpen maar het kan ook anders. Intermediair, 1978, 14, pp 1-11

Schreurs P J G, Tellegen B, Willige $G$ van de. Gezondheid, stress en coping: de ontwikkeling van de Utrechise Coping Lijst. Gedrag, Tijdschrift voor Psychologie, 1984, wol 1-2, pp 101-117

Schreurs $P$ J G, Van de Willige $G$. Gedragstherapie bij essentiele hypentensie. $T \vee$ Klinische Psychologie, Belgie, 1985 , vol 1

Schreurs P J G, Van de Willige G, Tellegen B, Brosschot $\mathrm{G}$. De Utrechtse Coping Lijst: UCL. Handleiding. Swets en Zeitlinger, Lisse, (in press)

Schwartz $\mathrm{G}$ E, Weiss $\mathrm{S} \mathrm{M}$. Behavioral medicine revisited: an amended definition. J Beháv Med, 1977. wol 1, pp 249-252

Schwartz G E, Shapiro, A P, Redmond D P, Ferguson D C E, Ragland D R, Weiss S M. Behawioral medicine approaches to hypertension: an integrated analysis of theory and research. J Behav Med, 1979, vol 2, pp 311-363

Scotch $\mathrm{N}$, Geiger $\mathrm{H}_{*}$. The epidemiology of essential hypertension: a review with special attention to psychologic and sociocultural factors. J Chronic Disease, 1963, wol 16, pp 1151

Scotch N. Blood pressure measurements of urban Zulu adults. Am Heart Journal, 1961, wol 61, pp 173

Shapiro A P e.a. The role of stress in hypertension. Jrl of Human Stress, 1979, vol S, pp 7-48

Shapiro $\mathrm{D}$, Goldstein $1 \mathrm{~B}$. Biobehavioral perspectives on hypertension. Irl Consult Clin Psychology, 1982, wol 50, pp 841-858 
Shekelle $\mathrm{R} \mathrm{B}_{n}$ Schoenberger I $\mathrm{A}_{3}$ Stamler $\mathbf{J}$ : Correlates of the JAS Type A behawiour pattern score. J Chronic Disease, 1976, vol 29, pp 381-394

Sheperd J T. Regulation of arterial blood pressure. pp 321-337 In: Arntszenius A C. Dunning A J, Snellen H A (eds), Blood pressure measurement and systemic hypertension, Medical World Press, Breda, 1981

Smirk F H. Casual basal and supplemental blood pressures in 519 first-degree relatives of substantial hypertensive patients and in 350 population controls . Clin Sc Molec Medic, 1976, vol $51, \mathbb{p p p} 13 \mathrm{~s}-17 \mathrm{~s}$

Smith T W, Brehm S S. Cognitive correlates of the type A coronary-prone behavior pattern. Motivation and emotion, 1981, vol 5, pp 215-223

Sokolow M, Werdegar D, Perloff D B, Cohan R M, Brenenstuhl H. Preliminary studies relating portably recorded blood pressure to daily life events in patients with essential hypertension. pp 164-189 In: Koster $M$ et al (eds). Psychosomatics in essential hypertension. Bibliotheca Psychiatrica no 144, Karger, New York, 1970

Son van M J M. Sociale vaardigheidstherapie, gedragstherapie en sociaal gedrag. Dissertatie Utrecht. Swets \& Zeitlinger, Lisse, 1978

Spielberger C D, Johnson E H, Russell S F, Crane R J, Jacobs G A, Worden T J. The experience and expression of anger: construction and validation of an Anger Expression Scale. In: Chesney M A, Rosenman $\mathbb{R}$ H. Anger and hostility in cardiovascular and behavioral disorders, McGraw-Hill Int Book Comp, 1985

SPSS-X user guide. McGraw-Hill Book Company, New York, 1983

Stamler J. Lectures in preventive cardiology, Grune and Stratton, New York, 1967

Stamler J e.a. Epidemiology and control of hypertension. Symposium Specialists, Miami, 1975

Steptoe A. Psychological factors in cardiovascular disorders. Academic Press, London, 191

Steptoe A, Ross A. Psychophysiological reactivity and the prediction of cardiovascular disorders. II Psychosomatic Research, 1981, wol 25, pp 23-31

Steptoe A, Melville D, Ross A. Behavioral response demands, cardiovascular reactivity, and essential hypertension. Psychosomatic Medicine, 1984, voll 46, pp 33

Steptoe A, Godaert G, Ross A, Schreurs P J G. The cardiac and vascular components of pulse transmission time: a computer analysis of systolic time intervals. Psychophysiology, 1983, wol 20, pp 251-260

Steptoe A. Behavioural influences on the mechanisms of hemodynamic regulation. pp 169-178 In: Orlebeke J F, Mulder $\mathrm{G}$, Doornen L J P van (eds). Psychophysiology of cardiowascular control, Plenum Press, New York, 1985

Steptoe A. Contemporary psychosomatic theories of essential hypertension. In: Lacey J, Sturgeon D (eds). Proceedings of the 15th European Conference on Psychosomatic research. John Lubbey \& Co, 1986

Surwit R S, Willians R B, Shapiro D. Behavioral approaches to cardiovascular disease, Academic Press, New York, 1982

Svensson $\mathrm{J} C$, Theorell $T$, Life events and elevated blood pressure in young men. Irl of Psychosomatic Research, 1983, vol 27, pp 445-457

Syme S L; Oakes T W, Friedman G D. Social class and differences in blood pressure. Am J Public Health, 1974, vol 64, pp 619-620

Syme S L. Psychosocial determinants of hypertension. In: Onesti G, Klimt C R (eds). Hypertension. Determinants, complications, and intervention, Grune and Stratton, New York, 1979 
Talbott E, Helmkamp J, Matthews K A, Kuller L, Cottington E M, redmond C. Oceupational noise exposure, noise-induced hearing loss, and the epidiemiology of hight blood pressure. Am J Epidemiology, 1985, woll 121, pp 501-514

Taylor I A. A personality scale of manifest anxiety. J Abnormal Soc Psychology, 1953, wol 48, pp 285-290

Tennant $C$, Andrews $G$. The pathogenic quality of life event stress in neurotic impairment.. Archives of General Psychiatry, 1978, wol 35, pp 859-863

Theorell T. Selected illnesses and somatio factors in relation to two psychosocial stress indices a prospective study on middle aged construction building workers. J Psychosomatic Research, 1976, vol 20, pp 7-20

Theorell $T$, Svensson $J$, Low $H$, Nerell $\cdot G$. Clinical characteristics of 18-year-old men with elevated blood pressure. Acta Medica Scand, 1982, vol 211, pp 87-93

Theorell T, Svensson J, Knox S, Waller D, Alvarez M. Young men with high blood pressure report few recent life events. Irl of Psychosomatic Research, 1986, vol. 30, pp 243-249

Thomas C B, Duszynski K R. Blood pressure levels in young adulthood as predictiors of hypertension and the fate of the cold pressor test. John Hopkins Medical Journal, 1982, vol 151, pp 93-100

Uexkül won Th. Psychophysiologische Probleme der Essentiellen Hypertonie, pp 82-93. In: Fellinger K (ed). Funkionsablaufe unter emotionellen Belastungen, Konger, Basel, 1964

Valkenburg $\mathrm{H} A$, Hofman $A$, Klein $F$, Groustra $F \mathbb{N}$, Een epidemiologisch onderzoek maar risicoindicatoren voor hart en vaatziekten (EPOZ).I.Bloeddruk, serumcholesterolgehalte, quetelet-index en rookgewoonten in een open bevolking van vijf jaar en ouder. Ned $\mathrm{T}$ Geneeskunde, 1980, vol 124, pp $183-189$

Veen W van, Godaert G, Schreurs P J G. Lewen met verhoogde bloeddruk. Van Gorcum, Assen, 1980

Vickers R R, Hervig L K, Rahe R S, Rosenman R H. Type A behavior pattern and coping and defense. Psychosomatic Medicine, 1981, vol 43, pp $381-396$

Vingerhoets A J J M, Flohr P J M. Type A behaviour and self-reports of coping preferences. British Jrl of Medical Psychology, 1984, vol 57, pp 15-21

Weber M A, Drayer J I M, Wylle F A, Brewer D D. A representative value for whole day blood pressure monitoring. JAMA, 1982, vol 248, pp 1626-1628

Weder A B, Julius S: Behavior, blood pressure variability, and hypertension. Psychosomatic Medicine, 1985, wol 47, pp 406-413

Weidner $\mathrm{G}_{s}$ Matthews K A. Reported physical symptoms elicited by unpredictable events and the type A coronary prone behavior pattern. Jrl of Pers and Social Psychology, 1978, wol 36, pp $12113-1220$

Weiner H, Singer M T, Reiser M F. Cardiovascular responses and their psychological correlates: A study in healthy young adults and patients with peptic ulcer and hypertension. Psychosomatic Medicine, 1962, vol 24, pp 477

Weiner H. Psychobiology of essential hypertension. Elsevier. Amsterdam, 1979

Wennerholm $\mathrm{MA}$, Zarle $\mathrm{T} M$. Internal-external control, defensiveness and anxiety in hypertensive patients. Jrl of Clinical Psychology, 1976, vol 32, pp 643-648

Wesseling $\mathrm{K} \mathrm{H}$, Wit $\mathrm{B}$ de. Settels J J, Klawer $W \mathrm{H}$, Arntzsenus A C. On the indirect registration of finger blood pressure after Penaz: Funkt Biol Med, 1982, vol 1, pp 245.250

Westbrook M T. A classification of coping behavior based on multidimensional scaling of

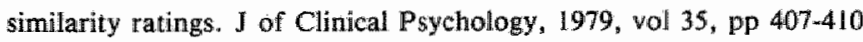


Wheatly D, Balter M, Lewine I et al. Psychiatric aspects of hypertension. Br Jrl of Psychiatry, 1975, woll 127 , pp $327-336$

WHO/ISH comittee. Ouidelines for the treatment of mild hypertension. The Lancet; $1983, \mathrm{i}^{*}$ $457-8$

Willems L F M, Tuender cle Haan H A, Defares $\mathrm{P} B$. Een schaal on sociale angst te meten. Ned T voor Psychologie, 1973, vol 28, pp $415-422$

Willige $G$ van de, Sorbi M, Kiluver R, Schreurs P J G, Godaert $G$, Vink l. Gedrag en gezondheid: een interactionele benadering . Gezondheid en Samenleving, 1983, wol 4, pp 32-41

Willige $O$ van de, Schreurs $P$, Tellegen $B$, Zwart F. Het meten van "life events": de Vragenlijst Recent Meegemaakte Gebeurtenissen (VRMG). Ned T Psychologie, 1985, wol 40, pp 1-19

Winnubst $J$ A M, Marcelissen F H G, Kleber R J. Effects of social support in the stressor-strain relationship: a Dutch sample. Sociall Science and Medicine, 1982, vol 16, pp 475-482

Woestenburg J, Schreurs P G . Pulse wave velocity" als index voor de bloeddruk voor biofeedback-doeleinden. Intern rapport Klinische Psychologie Utrecht, 1976

Wolf $S$, Wolff H G. A summary of experimental evidence relating life stress to pathogenesis of essential hypertension in man. In: Bell E T. Hypertension. Minnesota Uniw Press, Minneapolis, 1951

Wolf $S$, Cardon $P$, Shepard $E$, Wolff $H$. Life stress and essential hypertension. Williams and Wilkins, Baltimore, 1955

Wood D, Sheps S, Elveback L, Schirger A. Cold pressor test as a predictor of hypertension. Hypertension, 1984, vol 6, pp 301-306

Zimmerman M K. Perceived stress and coping behaviour: a social-psychological comparison of hypertensive and normotensiwe employees (abstract): Preventiwe Medicine, 1979, vol 8

Zimmerman M K, Hartley W S. High blood pressure among employed women: a multi-factor discrimininant analysis. Jrl of Health and Social Behavior, 1982, vol 23, pp 205-220

Zimmerman Mark. Methodological issues in the assessment of life events: a review of issues and research, Clinical Psychology Review, 1983, vol 3, pp 339-370

Zung W W K. A self rating depression scale. Arch Gen Psychiatry, 1965, vol 12, pp 63-70 


\section{BIJLAGE A}

\section{LEVENSOMSTANDIGHEDEN}

Auteurs: Van de wilisige, Schreurs.

\section{Toelichting:}

Hieronder staan een aantal korte vragen over dw levensomstandigheden. ze zijn gerangschikt per onderwerp. Allereerst een aantal vragen over de woning en de buurt waar u woont. Daarna komen er vragen over de werksituatie, de situatie thuis, kontakten met familie, vrienden en kennissen, de financiele situatie en tenslotte een aantal vragen over uw jeugd.

\section{A. Woning en woonomgeving}

1. Als u ergens ander zou kunnen gaan wonen, zou u dan willen verhuizen........................ ja $\square$ nee $\square$

2. Bijna geen enkele woning is volledig ideaal. Indien $u$ om de een of andere reden ontevreden bent over uw woning, wilt u dit dan aangeven met een kxuisje bij het betreffende antwoord.

U kunt zoveel hokjes aankruisen alsi van toepassing zijn.

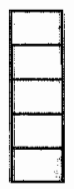
te duur
te klein
te gehorig
te onvrij
te groot

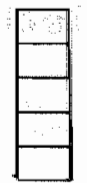

slechte staat van onderhoud te afgelegen

onenigheid met huiseigenaar ontevreden over het: soort woning (bijv. flat, bovenhuis)

Indien $u$ andere klachten heeft, wilt u die dan hieronder opschrijven.

3. Hoe tevreden bent u over het geheel genomen met uw woning?

(Wilt u dit aangeven met een eljfer tussen 1 en 10 , waarbij 1 betekent:

"heel erg ontevreden" -ik wil hier het liefst zo snel mogelijk vandaanen 10 betekent "uitermate tevreden" -ik zou hier altija wel willen blijuen-)

zeer

ontevreden

\begin{tabular}{|l|l|l|l|l|l|l|l|l|l|}
\hline 1 & 2 & 3 & 4 & 5 & 6 & 7 & 8 & 9 & 10 \\
\hline
\end{tabular}

witermate tevreden

4. Hoe tevreden bent $u$ over het geheel genomen met de buurt warin w woont? (s.v.p. een cijfer aankruisen tusisen 1 en 10 )

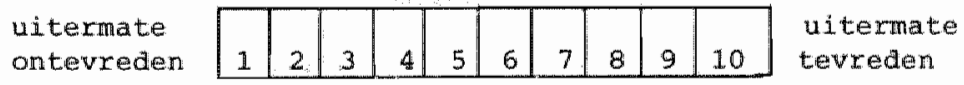


5. Indien $u$ op de een of andere manier ontevreden bent over de buurt waar $u$ woont, wilt u dit dan aangeven met een kruisje bij het betreffende antwoord. j kunt zoveel hokjes aankruisen als van toepassing zijn.

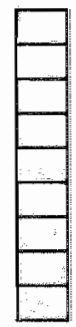

te druk, te veel verkeer

weinig groen en bomen

slechte bereikbaarheid

te saal

buurt wordt verwarloosd

" $s$ avonds en 's nachts onveilig

te veel lawaal en stank (verkeer, fabrieken)

geen goede voorzieningen zoals winkel, bibliotheek, café's enz. omprettige buren

Indien ex nog andere klachten over de buurt hebt, wilt u die dan hieronder opschrijven:

\section{B. Werkbelasting}

1. Zijn er in uw werkomgeving mensen waarmee u op gespannen voet leeft?...................... ja $\square$ nee

2. Vindt $u$ dat $u$ in uw werk voldoende gewaardeerd wordt?. . ja $\square$ nee $\square$

3. Zou u liever een ander soort baan hebben/ander werk doen?. . . . . . . . . . . . . . . . . .

4. Hebben bepaalde kanten van uw werk een nadelige invloed op uw privëleven?. ................. ja $\square$ nee $\square$

5. Indien u om de een of andere reden ontevreden bent over uw werk, wilt $u$ dit dan aangeven met een kruisje bij het betreffende antwoord. u kunt weer zoveel hokjes aankruisen als volgens u van toepassing zijn.
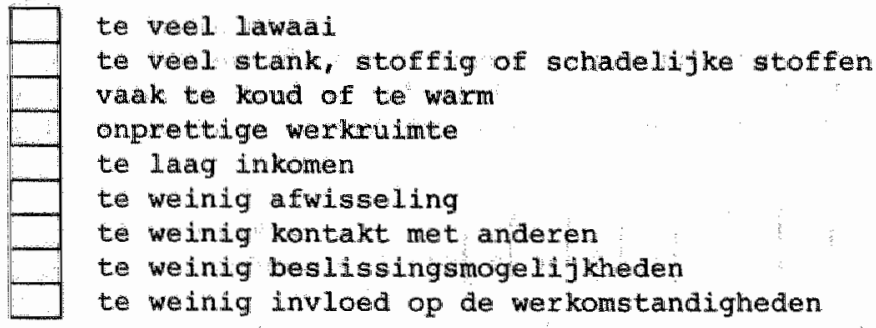

Indien er nog andere zaken zijn waarom u ontevreden bent over uw werk, wilt u die dan hieronder opschrijven: 
6. Hoe tevreden bent $\mathrm{u}$ over het geheel genomen met uw huidige werkzaamheden? uitermate ontevreden

\begin{tabular}{|l|l|l|l|l|l|l|l|l|l|}
\hline 1 & 2 & 3 & 4 & 5 & 6 & 7 & 8 & 9 & 10 \\
\hline
\end{tabular}

uitermate tevreden

\section{c1. Sociale steun vrienden}

De volgende vragen gaan over mensen die geen familie van $u$ algh: vrienden, goedle kennissen. Voor het gemak spreken we telkens over "vrienden", ook al gaat het misschien maar om ển-persoon of om ëén of meerdere vriendinnen. Bij deze vragen gaat het ook om degene met wie $u$ (eventueel) een vaste relatie hebt, maar die niet bij $u$ in huis woont: vaste vriend of vriendin. verloofde, enz.

1. Hebt u de afgelopen 14 dagen nog bezoek gehad van vrienden of bent u zelf nog bij hen op bezoek geweest?...... j

2. Raadpleegt u vrienden als $u$ een belangrijke beslissing moet nemen?

ja $\square$ nee

3. Gaat $u$ wel eens samen met vrienden naar een cafe, bioskoop, uit eten, enz............................... nee $\square$

4. Praat u wel eens met vrienden over persoonlijke moeilijk-

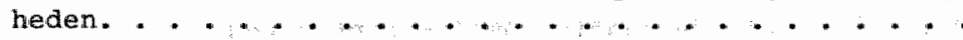

5. Als u ergens mee zit, zijn er dan altijd wel vrienden die de helpende hand bieden of bijspringen?.........

6. Hoe tevreden bent is over het geheel genomen over de kontakten met vrienden en kennissen?
uitermate
ontevredien

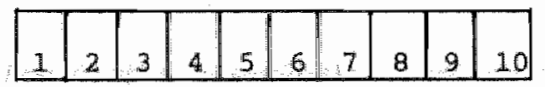
uitermate
tevreden

7. Hoe belangrijk vindt $u$ de kontakten met vrienden en kennissen? in het geheel niet

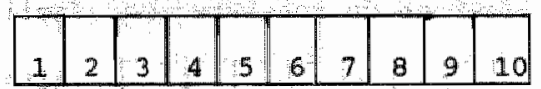

uitermate belangrijk

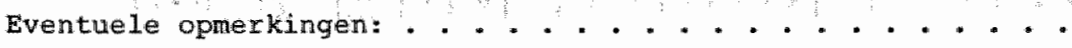




\section{C2. Soctale steun buren}

1. Hebt w de afgelopen 14 dagen nog bezoek gehad van mensen uit de buurt of bent u zelf nog bij lemand wit de buurt

op bezoek geweest?. ................ ja $\square$ nee $\square$

2. Rekent u enkele van uw buren tot uw vriendenkring?. . . ja $\square$ nee $\square$

3. Praat $u$ wel eens met buren over persoonlijke aange-

legenheden?

nee

\section{C3. Soclale steun kollega's}

1. Komen u en uw kollega's wel eens thuis bij elkaar op bezoek?................................. $\square$ nee $\square$

2. Prat u met kollega"s over persoonlijke aangelegenheden? ja $\square$ nee $\square$

\section{C4. Sociale steun familie}

Bij deze vragen gaat het om de naste familieleden, zoals ouders, broers, zusters, uitwonende kinderen, schoonfamilie, enz.

1. Met hoeveel personen ult de naste familie hebt u regelmatig (minstens 1 x per 14 dagen) kontakt?....... . personen

2. Hebt u de afgelopen 14 dagen nog bezoiek van familieleden gehad of bent $u$ zelf nog bij hen op bezoek geweest?. . .

nee

3. Bespreekt u met familie uw persaonlijke aangelegenheden en moeilijkheden?. . . . . . . . . . .....

4. Kunt a een beroep doen op familieleden als a hulp nodig heeft?..........................

5. Hoe verlopen over het algemeen de kontakten met familieleden?

uitermate onplezierig

\begin{tabular}{|l|l|l|l|l|l|l|l|l|l|}
\hline 1 & 2 & 3 & 4 & 5 & 6 & 7 & 8 & 9 & 10 \\
\hline
\end{tabular}

uitermate plezierig

\section{Partnerrelatie}

Het gat hier om degene met wie u (al dan niet getrouwd) een vaste relatie hebt en in een huis samenwoont. Voor het gemak spreken we steeds over "de partner" Indien u geen vaste partner hebt kunt u deze vragen overslaan en verder gaan met de vragen onder $\mathbf{E}$.

1. Vindt u dat uw partner voldoende aandacht voor uw werk en interesses heeft?. 
2. Bespreekt u persoonlijke moeilijkheden altija met

elkaar?

3. Hebt $u$ er wel eens over gedacht om ult elkar te gaan?

ja $\square$ nee $\square$

4. Hebt $u$ het gevoel dat $u$ eigenlijk teveel langs elkar

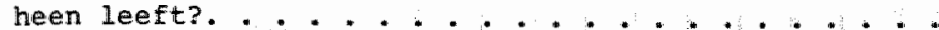

5. Over welke van de volgende onderwerpen zijn u en uw partner het regelmatig met elkar oneens? Wilt w dit angeven met een kruisje bij het betreffende antwoord.

\begin{tabular}{|l}
$\square$ \\
$\square$ geldzaken \\
vakanties \\
uitgaan \\
vrienden/vriendinnen \\
seksualiteit \\
geloof \\
bezigheden in de \\
vrije tijd
\end{tabular}

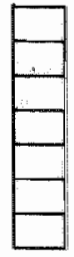

bepaalde eigenschappen van uw partner bepaalde eigenschappen van uzelf alkohol of roken bezoek van en aan (schoon)famille buitenechtelijke relaties opvoeding kinderen aanta 1 kinderen

6. Hoe tevreden bent $u$ in het geheel genomen met uw huwelijk/relatie?

uitermate ontevreden

\begin{tabular}{|l|l|l|l|l|l|l|l|l|l|}
\hline 1 & 2 & 3 & 4 & 5 & 6 & 7 & 8 & 9 & 10 \\
\hline
\end{tabular}

uitermate tevreden

\section{E. Jeugdervaring}

De volgende vragen gaan over de periode vanaf uw geboorte tot ongeveer 18 jaar.

1. Was de sfeer over het algemeen prettig bij u thuis vroeger?....................... ja $\square$ nee

2. Had u vaak onenigheld met ến of belde ouders?.... . ja $\square$ nee

3. Kon u de meeste zaken met uw ouders bespreken, m.a.w. waren uw vader of moeder echte vertrouwenspersonen?

4. Voelle a zich vroeger vaak alleen staan?...... ja $\square$ nee $\square$

5. Hebt u alles bij elkaar genomen een gelukkig jeugd gehad? zeer ongelukkig

\begin{tabular}{|l|l|l|l|l|l|l|l|l|l|}
\hline 1 & 2 & 3 & 4 & 5 & 6 & 7 & 8 & 9 & 10 \\
\hline
\end{tabular}

$z e \mathrm{r}$ gelukigig

F. Vrije tija

1. Hebt u een aantal hobby" $s$, bezigheden warin u zich kunt

2. Hebt u altijd voldoende bezigheden in uw vrije tijd?. . . ja $\square$ nee $\square$ 
3. Zou u meer vrije tifd willen hebben?......... ja $\square$ nee $\square$

4. Verveelt u zich wel eens in het weekend?........ ja $\square$ nee $\square$

5. Hoe tevreden bent u ower het geheel genomen met uw vrije tija?

ul termate ontevreden

\begin{tabular}{|l|l|l|l|l|l|l|l|l|l|}
\hline 1 & 2 & 3 & 4 & 5 & 6 & 7 & 8 & 9 & 10 \\
\hline
\end{tabular}

uitermate tevreden

6. Hoe belangrijk is vije tija voor u?

totaal

onbelangrijk

\begin{tabular}{|l|l|l|l|l|l|l|l|l|l|}
\hline 1 & 2 & 3 & 4 & 5 & 6 & 7 & 8 & 9 & 10 \\
\hline
\end{tabular}

uitermate

onbelangrijk

Eventuele opmerkingen:

\section{G. Problemen met kinderen}

1. Hebt u kinderen?................. ja $\square$ nee $\square$ Indien ja, hoeveel?. . . . . . . . . . ............

Als u geen kinderen hebt, kunt $u$ onderstaande vragen overslaan en verder gaan met de vragen onder $\mathbb{H}$.

Voor het gemak spreken we telkens over "de kinderen", ook al heeft u misschien slechts éen kind.

2. Heeft u regelmatig ernstige meningsverschillen met uw kinderen?............................ $\square$ nee $\square$

3. Zijn er opvaedings- en gedragsmoeilijkheden met éen van de kinderen?. ........................... $\square$ nee $\square$

4. Hebt $\mathrm{u}$ af en toe het gevoll het kontakt met de kinderen

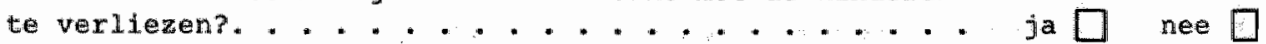

5. Hebt u het gevoel dat $u$ als ouder regematig tekort

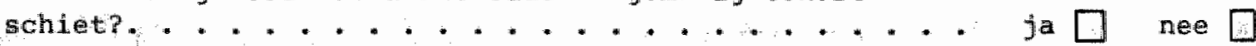

6. Hoe ervart $\mathrm{u}$ het on kinderen te hebben?

uitermate negatief

\begin{tabular}{|l|l|l|l|l|l|l|l|l|l|}
\hline 1 & 2 & 3 & 4 & 5 & 6 & 7 & 8 & 9 & 10 \\
\hline
\end{tabular}

uitermate positief 


\title{
BIJLAGE B
}

\author{
VPAGENLIJST RECENT MEEGEMAAKTE GEBEURTENISSEN (VRMG) \\ Auteurs: van de Willige, Schreurs, Tellegen en Zwart.
}

\section{Toelichting}

In deze lijst worden een aantal gebeurtenissen genoemd, die lemand kan hebben meegemaakt. Het is de bedoeling dat $u$ bij uzelf nagaat weike van deze gebeurtenissen zich in het afgelopen jaar bij u hebben voorgedaan (of nog voordoen). In de lijst geeft $u$ dit aan door in het eerste hokje achter de gebeurtenis een kruisje te zetten. Als $u$ een gebeurtenis de laatste 12 maanden niet hebt meegemaakt dan vult u niets in.

Van de gebeurtenissen die u hebt meegemaakt en aangekruist, vragen wiju tevens om aan te geven hoe plezlerig én hoe onplezierig u die gebeurtenis hebt gevonden. U kunt zowel voor de onplezlerigheld als voor de plezierigheld kiezen uit 5 antwoordmogelijkheden.

\section{Voorbeelden}

A. -Een bepaalde gebeurtenis heeft nogial wat onplezierigheid met zich meegebracht, mar ex zaten ook enige plezlerige kanten aan. In dit geval plaatst u achter de betreffende gebeurtenis in de le plaats een kruisje in het hokje onder "meegemaakt" en verder in de hokjes onder "nogal wat onplezierigheid" en "enige plezlerigheid", zoals hieronder aangegeven:

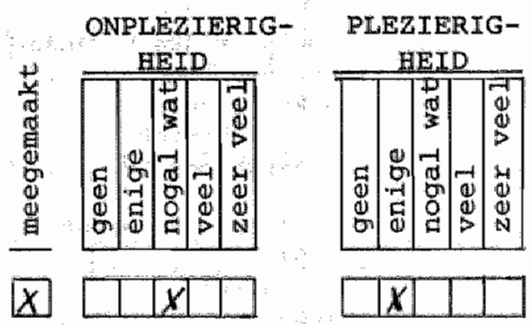

Gebeurtenis A

B, -Wanneer een gebeurtenis veel oplezierigheid teweeg heeft gebracht en in het geheel

geen plezierigheid, dan vult u dit als volgt in:

Gebeurtenis B . ................
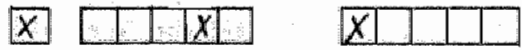

C. -Evenzo, wanneer een gebeurtenis zeer ple-

zierig is geweest en helemal niet onplezierig:

Gebeurtenis C . . . . . . . . . . .
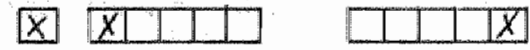

Per meegemakte gebeurtenis worden dus altijd 3 hokjes ingevuld. Wanneer u een gebeurtenis niet hebt meegemaakt in het afgelopen jaar, dan blijven de hokjes achter die gebeurtenis leeg. 
PLEZIERIG-
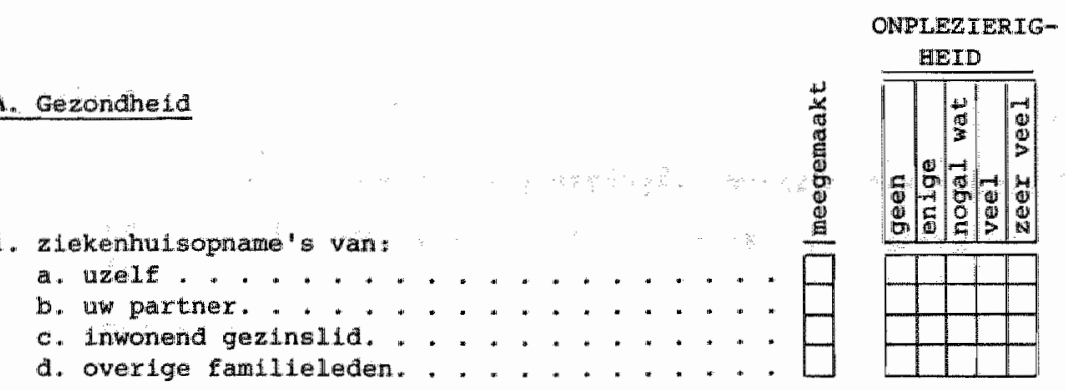

EIETD

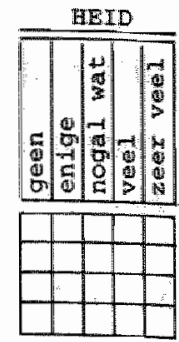

2. operatie van:
al. azel 1 .
b. uw partner
d. overlge familieleden.

3. een zidekte of verwonding waraoor minsters een mand de dagelijkse gang wan zaken is verstoord:

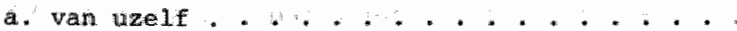

b. wan inworend gezinslid.

4. een behandeling in verband thet persoonlifke problemen wan:
a. uzelf
b. uw partier.
c. inwonend gezinslid.

5. een belangrijke werandering in:
a. eetgewoonten
b. alkoholgebruik.
c. rookgewoonten "
a. slaapgewoonten

6. een belangrijke weramdering in de gezondheid van
a. uze If . . . . . . . . . . . . . . . . .
b. uw partier.

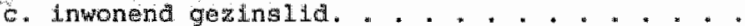
d. overlge famllieleden. . . . . . . . . . . . .
e. goede vriend(in) of burur.

\section{Werk}

7 . verandex 1 ing van werkgever

$\square$

8. änder werk madr bij dezelfale werkgever......

9. vermadering van werktjden foveruren, werktijavewkowting) of var wexkomstandigheden. . . . ..

10. vexanderlng in varantwoordelijkheid op uw werk

11. begin van onenighedd of konflikt op wwerk. " *

12. een verandering binnen het bedrijf of de inste1ling wat a werke (remorganisatie e.d.)...".
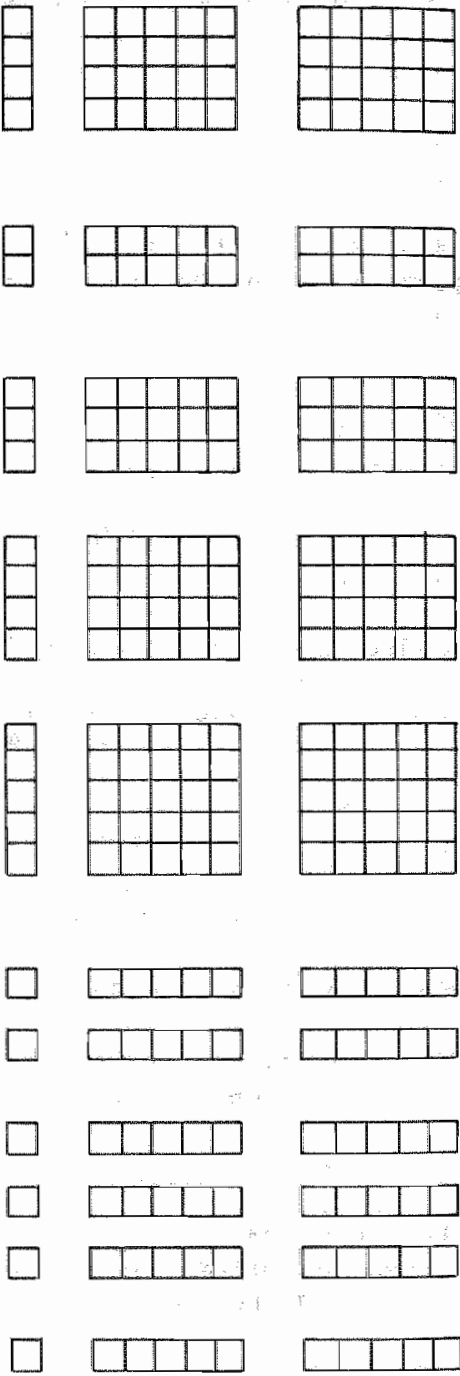


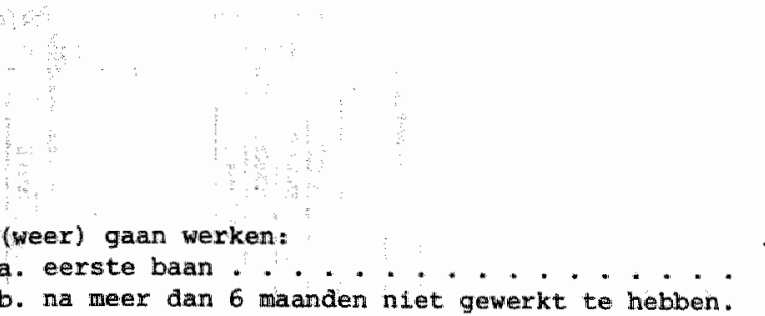

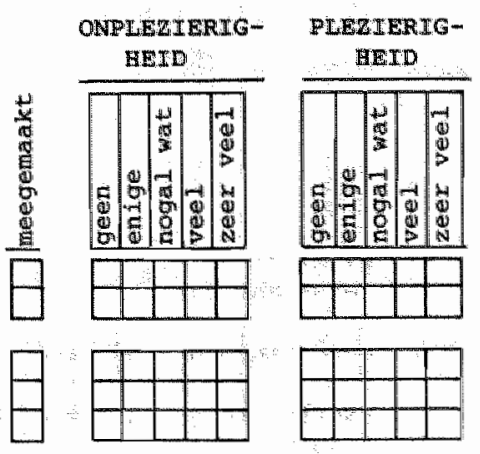

15. Een maand of langer werkeloos (na ininstens zes maanden werk bij dezelfde werkgever)

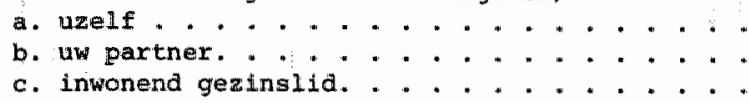
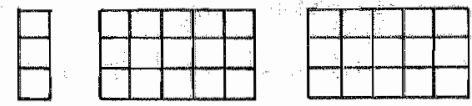

16. promatie
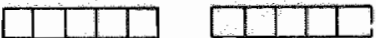

17. het vertrek van lemand met ile u nauw heeft samengewerkt .
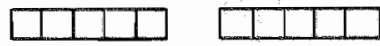

\section{Familie en vriender}

18. een belangrijke verandering in gedxag van:
a. ww partner.
b. Inwonend gezinsila.
c. overige familleleden. . . . . . . . ...
c. een goede vriend(in) of buur. . . . ......

19. in het huwelijk getredem of gaan samenwonen.

20. een duldelijke verandering in de verhouding met uw partner
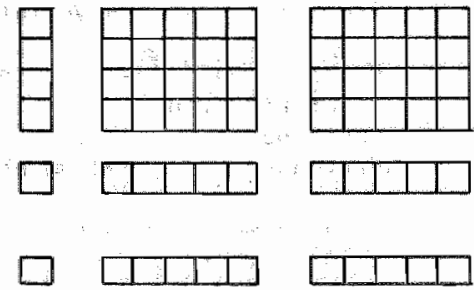

21. een schelding van minstens een maand van uw partner wegens:

a. werk.
b. relatleproblemen.
c. andere reden
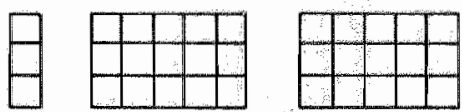

22. buitenechtelijke relatie:

a var uzelf. . . . . . . . . . " . . . . ."

b. van uw partner.

23. een definitieve schelaing

$\square$
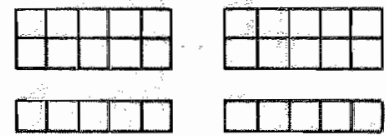

24. Uw partner is begonnen of gestopt met werken bultenshuis. . . . . . . . . . . . . . .

25. vrouw: zwangerschap. . . . . ....... man: zwangerschap partner. ............

26. vrouw abortus .................... man: abortus partner

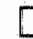
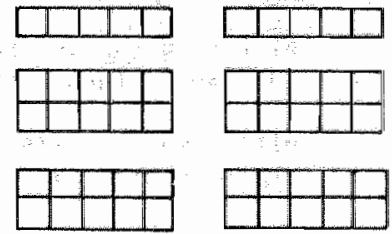


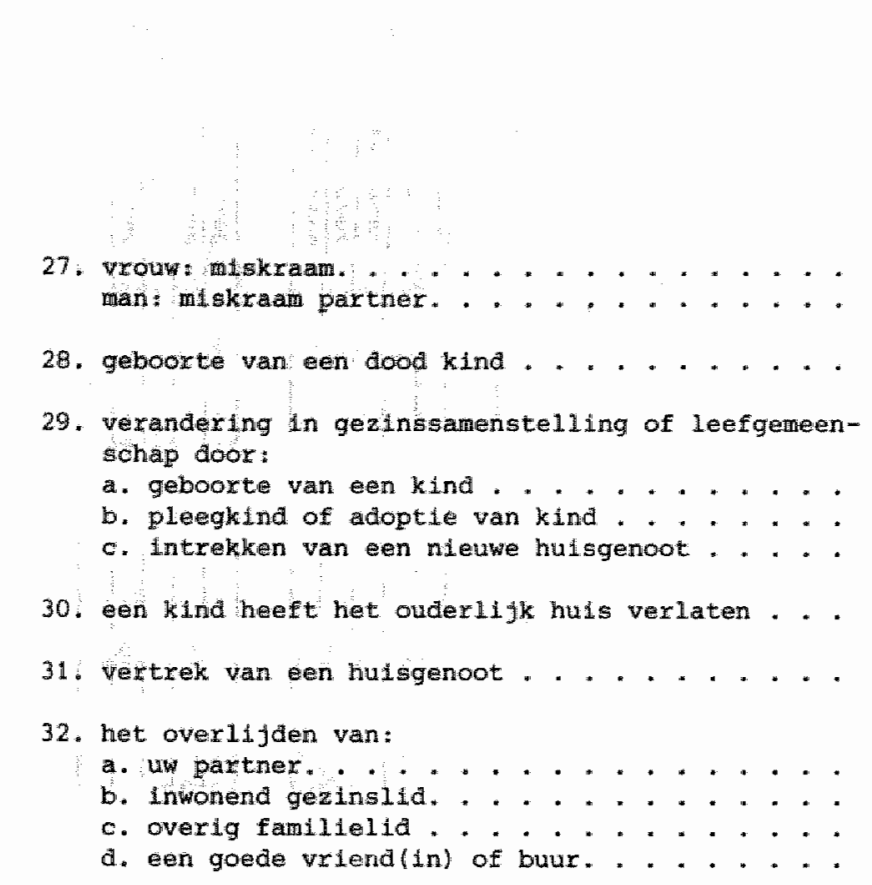

33. het overlijden van een gellefd huisdier. . . . .

34. een verandering in samenlevingsvorm van uw ouders of kinderen:

a. scheiding . . . . . . . . ....

b. hertrouwen of niedwe hechte relatie.....

35. begin van huwelijksproblemen bij uw ouders, broers of zusters of kinderen.

36. geboorte van een kleinkind.

37. konflikt (en) met:
a. tuw partnex.
B. uw kinderen.
c. ww (schoon) taming

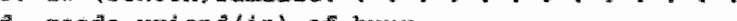
a. goede vriend $(i n)$ of buur.

38. en verandering in ae kontakten met:

a. wiw (schoon) famille. . . . . . . . .

b. buren of goede vrlenden
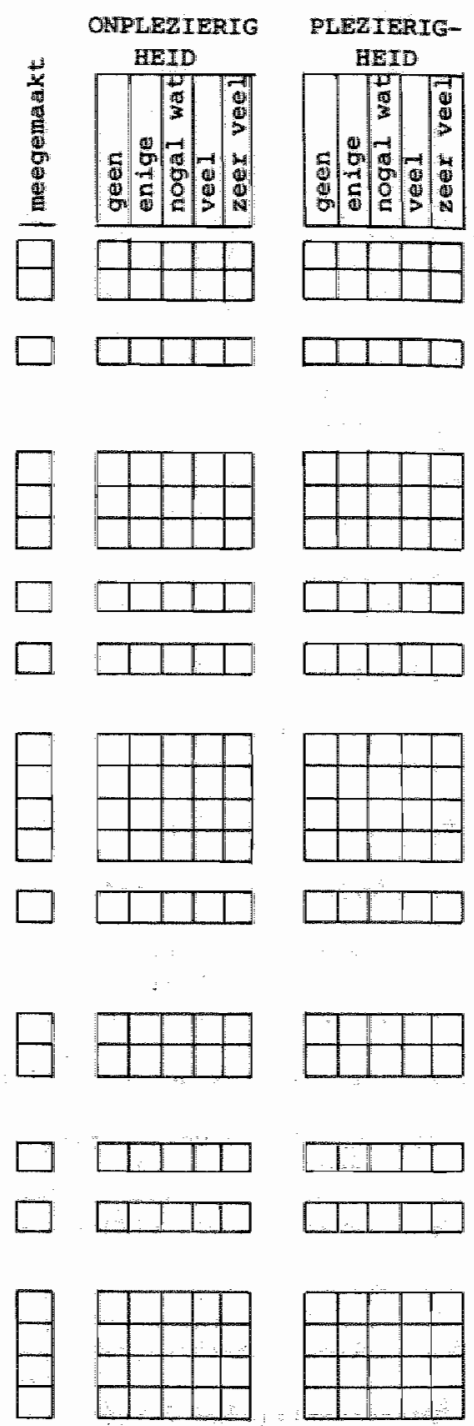

39. Cen nieuwe hechte relatie of vriendschap....
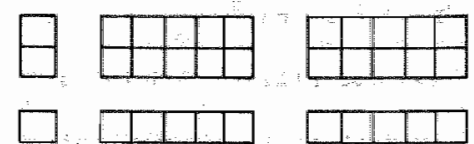

40. de verbreking vam een hechte relatle of

41. verhuizing van ouder(s) naar bejaardentehuis of verzorgingstehuis: 


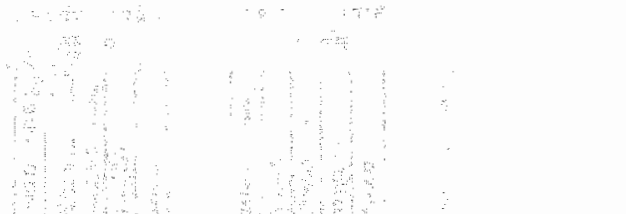

D. Wonen en persoonlijke omstandigheden

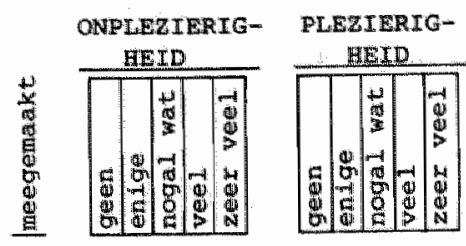

42. een werhuizing:

a binnen uw woonplaats. . . . . . , . .,...
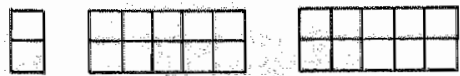

43. een belangrijke verandering in woonomstandlgheden (woning verbeterd of verslechterd, achter-

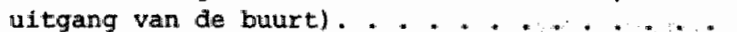

44. konflikten met hulseigenaar, medebewoners, buurtbewomers of gemeente.
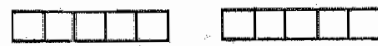

45. zelfstandig gaan wonem
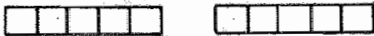

46. een belangrijke beslissing genomen over uw nablje toekomst

47. een belangrijke verandering in uw manier van leven, zoals meer of minder ultgran, aan sport gaan doen of 11d worden vam een vereniging enz..

48. onderschelding, thedallle of eerbetulging voor een (persoonlijke) prestatie...........
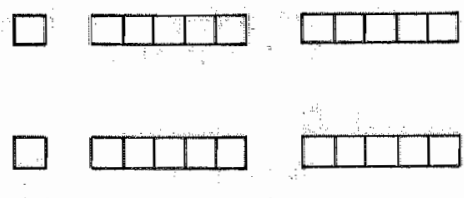

49. een verandering van uzelf in:
a. geloof of levensovertulging . . . . . . . . .
b. politieke overtuiging

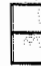
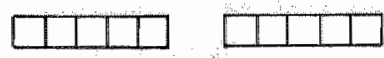

50. eem verandertng van gezinsild in:
a. geloof of levensovertulgling . . . . . . . . .

b. politieke overtulging
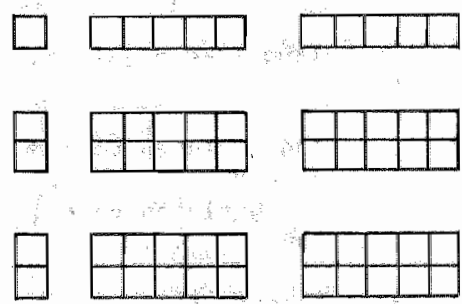

51. oplelaing of stuale van wzelf of gezinilia:
a. beginnen aan een opleiding..............
b. veranderen van oplelalng.
c. voortijalg ophouden met een opleiding . : .
a. voorbereiden en/of afleggen vari een belang- rijk examen . . . . . . *...........
e. met succes afronden van gen apleiding. . * .
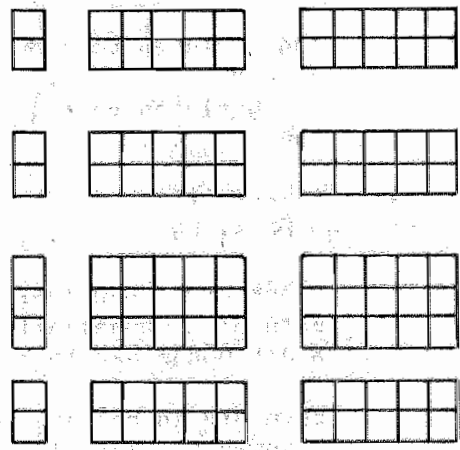

52. elgen overtreding met rechtzaak tot gevolg:
a. ernstige boete (meer dan $f$ 1000\%........
b ontzegging wan de rijbewoegdheld.
c. voorwaardelijke viljheldsstraf. . . . . . . .
d. celstraf. . . . .................
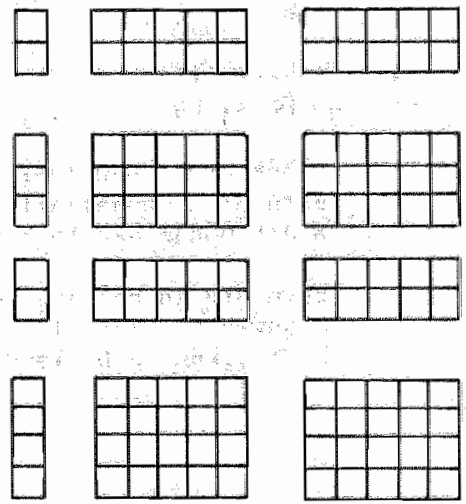
53. overtxeding met rechtszaak tot gevolg door naaste

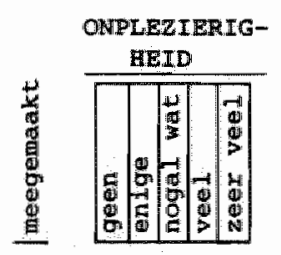

PLERIERIG-

familie, ouders, broers, zusters, partner, kinderen:
a. ernstige boete (meer an $f$ 1000).........
b. ontzegg ing van de rifbevoegdheid........
c. voorwardielijke vrljheldsstraf. ". . . . . .
d. celetrat.
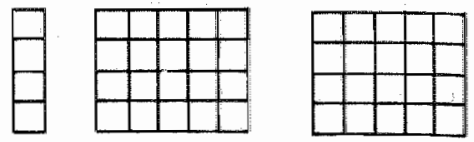

54. verlies van of schade aan persoonlljke eigendommen
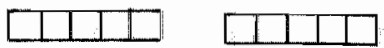

55. slachtoffer van kriminalitelt:

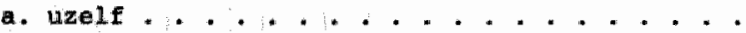

b. Inwonend gezinsild.<smiles>C1CC2CCC12</smiles>
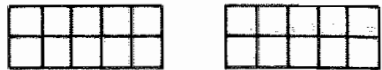

56. betrokken geweest bij of getuige geweest van een ongeluk of ongeval.
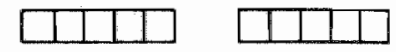

\section{E. Financlên}

57. a een belangrijke aankoop.............. b. een belangrijke verkoop . . . . . . . . . . .<smiles>C1CC2CCC12</smiles>
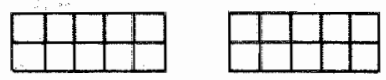

58. eem belangrijke wijalging in uw financlele toestand.
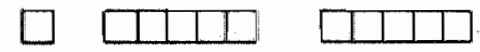

59. Iening gesloten voor de arakoop van huisraad,

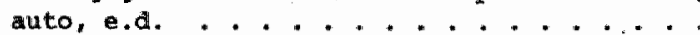

b. Lening gesloten voor de aankoop wan een huls of raak ........................
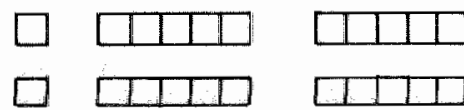

60. falilisement of inname van goederen wegens niettijdige betaling . . . . . . . . . . . . .
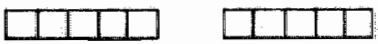

Indien 1 in het afgeloper jaar geen van bovenstaande gebeurtentssen hebt meegemakt, wilt u dan zo vriendelljk ijn at hokje an te kruigen..........

Gebeurtenissen die In het afgelopen jaar voor u van belang aljn geweest, max die niet in bovenstande lijgt vookkomen, kunt u hleronder vermelden

61.
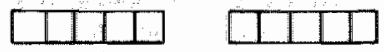

62.
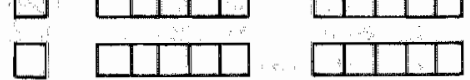


\section{BIJLAGE C}

Indices van gebeurtenissen, onderverdeeld naar geslacht, burgerlike strat en leeftijd (uit: Wan de Willige e.a., 1985)

\begin{tabular}{|c|c|c|c|c|c|c|}
\hline & \multicolumn{3}{|c|}{ Geslacht } & \multicolumn{3}{|c|}{ Burg. staat } \\
\hline & $M$ & $V$ & $\begin{array}{l}\text { t-waarde } \\
\text { sign }\end{array}$ & Geh. & Ongeh. & $\begin{array}{l}\text { P-waarde } \\
\text { sign }\end{array}$ \\
\hline Aantal gebeurtenissen & 6.08 & 7.21 & -1.42 & 5.92 & 7.81 & $2.29^{*}$ \\
\hline Totale onplezierigheid & 15.33 & 19.23 & -1.76 & 15.23 & 18.53 & 1.66 \\
\hline Gemiddelde onplezierigheid & 2.36 & 2.65 & -1.63 & 2.40 & 2.33 & -.50 \\
\hline Totale plezierigheid & 14.15 & 18.60 & -1.69 & 13.49 & 20.99 & $3,08^{*}$ \\
\hline Gemiddelde plezierigheid & 2.20 & 2.40 & -1.15 & 2.17 & 2.51 & $2.41 *$ \\
\hline Verschilscore & -1.18 & -.63 & 36 & -1.74 & +2.46 & $-2.85 * *$ \\
\hline $\mathrm{N}=$ & 461 & 43 & & 431 & 72 & \\
\hline
\end{tabular}

\begin{tabular}{|c|c|c|c|c|c|}
\hline & \multicolumn{5}{|l|}{ Leeftivd } \\
\hline 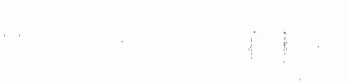 & $<33 j r$ & $4-43 \mathrm{jr}$ & $4-53 \mathrm{jr}$ & $\$ 53 \mathrm{jr}$ & $\begin{array}{l}\text { F-waarde } \\
\text { sign }\end{array}$ \\
\hline Aantal gebeurtenissen & 8.51 & 5.54 & 5.65 & 4.66 & $116.26^{* * *}$ \\
\hline Totale onplezierigheid & 20.50 & 14.32 & 14.98 & 12.05 & $9.07^{* * *}$ \\
\hline Gemiddelde onplezierigheid & 2.32 & 2.36 & 2.43 & 2.44 & .38 \\
\hline Totale plezierigheid & 22.56 & 12.15 & 11.87 & 10.38 & $25.92^{* * * *}$ \\
\hline Gemiddelde plezierigheid & 2.58 & 2.10 & 2.03 & 2.11 & $7.02^{* * * *}$ \\
\hline Verschilscore & +2.06 & -2.17 & -3.10 & -1.67 & $7.67^{* * *}$ \\
\hline $\mathrm{N}=$ & 139 & 114 & 133 & 118 & \\
\hline
\end{tabular}

$* p=<.05 \quad * * 0<<.01 \quad * * * 0<.001$. 
BIJLAGE D

\section{OMGAAN MET PROBLEMEN EN GEBEURTENISSEN DE UTRECHTSE COPINGLIJST (UCL)}

1983 c P.J.G. Schreurs en G. van de Willige

$\begin{array}{ll}\text { Nam: } & \text { Sexe:Man/Vrouw } \\ \text { Geboortedatum: } & \text { Opleiding: }\end{array}$

Toelichting :

Mensen reageren vaak heel verschillend als zij met problemen of onplezierige gebeurtenissen te maken krijgen. Wat men in een bepaald geval doet hangt sterk af van de aard van het probleem of de gebeurtenis, en de ernst ervan. Toch reageert men OVER HET ALGEMEEN wat vaker op de ene dan op de andere manier.

Hieronder staan een aantal beschrijvingen die angeven wat men zoal kan denken of doen als er problemen zijn. WILT U ACHTER IEDERE ZIN AANGEVEN HOE VAAK U IN HET ALGEMEEN OP DE BESCHREVEN MANIER REAGEERT. U kunt dit doen door bij iedere zin in eén van de hokjes een kruis te zetten. Et zijn geen goede of foute antwoorden. Wilt U s.v.p. geen zinnen overslaan.

zelden
of nooit soms vaak valk

1. Je bedenken dat er nog wel ergere dingen kunnen

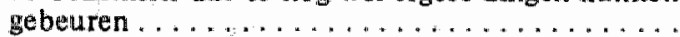

2. Proberen je te ontspannen

3. Je volledig afzonderen van anderen

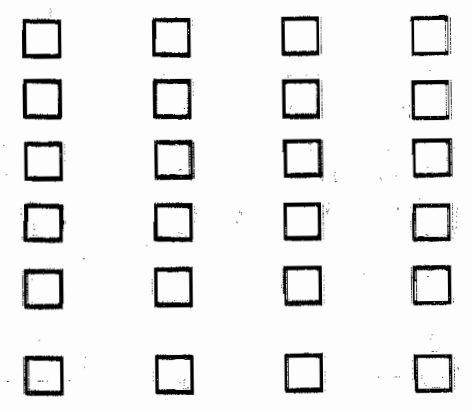

7. Laten zien dat je kwaad bent op degene die verantwoordelijk is voor het probleem .............

8. Toegeven om moeilijke situaties te vermijden....

9. Je neerleggen bij de gang van zaken . . . . . .

10. Je zorgen met iemand delen $\ldots \ldots \ldots \ldots \ldots$

11. Direct ingrijpen als er moeilijkheden zijn ......

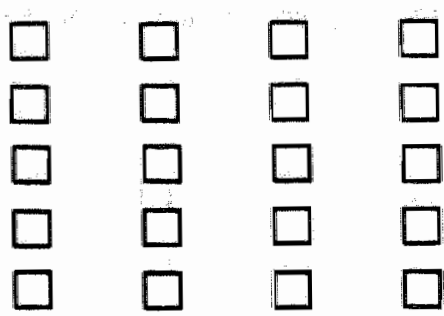

12. Tegen jezelf zeggen dat het allemal wel mee zal

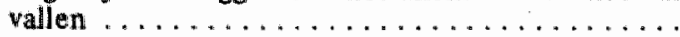

13. Problemen als een uitdaging zien
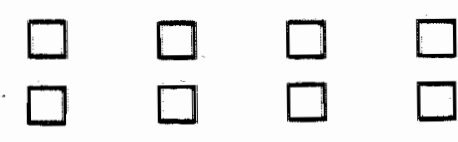
zeliden

14. Je zorgen tijdelijk verdrijven door er even uit te

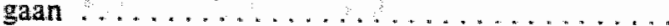

15. De kat uit de boom kijken

16. Spanningen proberen te verminderen door bijv. meer te roken, drinken, eten of beweging nemen.

17, Afleiding zoekem

18. Een probleem van alle kanten bekijken

19. Moeilijke situaties zoveel mogelijk uit de weg gaan.

20. Optimistisch blijven over de toekomst

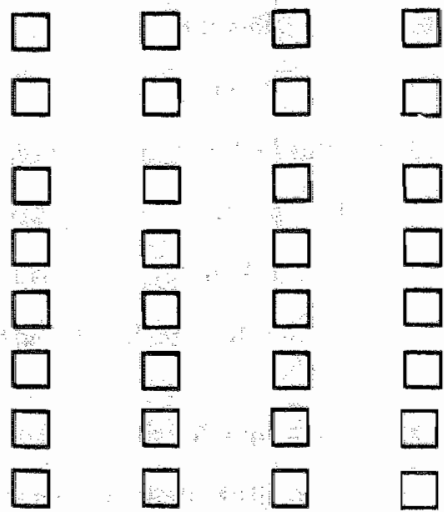

21. Kalm blijven in moeilijke situaties

22. Verschillende mogelijkheden bedenken om een probleem op te lossen . . . . . . . . . . . . . . . .

23. Doelgericht te werk gaan om een probleem op te lossen

24. Piekeren over het verledien

25. Opgewekt gezelschap zoeken als je je zorgen makt of van streek bent . . . . . . . . . . . .

26. Proberen je te onttrekken an een situatie .....

27. Je spanmingen afreageren $\ldots \ldots \ldots \ldots \ldots \ldots$

28. Wachten op betere tijden $\ldots \ldots \ldots \ldots \ldots \ldots$

29. lemand om hulp wragen $\ldots \ldots \ldots \ldots \ldots \ldots$

30. Rustgevende middelen gebruiken als je je gespannen woelt of nerveus bent

31. Wegwluchten in fantasie ${ }^{2} \ldots \ldots \ldots \ldots \ldots$

32. De zaken eerst op een rij zetten

33. Je geheel en al in beslag laten nemen door problemen .........................

34. Aan andere dingen denken die niet met het probleem te maken hebben ................

35. Op de een of andere manier proberen je wat prettiger te voelen. ....................

36. Je bedenken dat anderen het ook wel eens moeilijk hebben
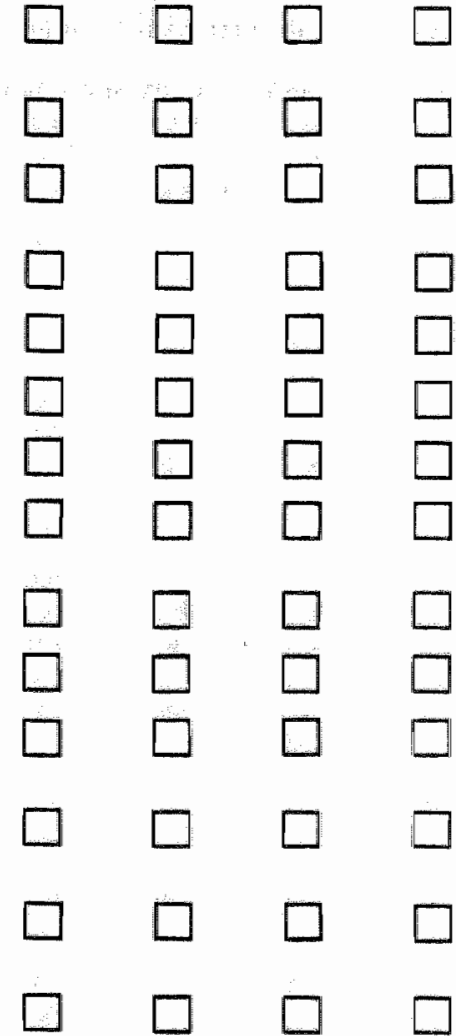

37. Je bedenken dat na regen zonneschijn komt .....

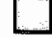




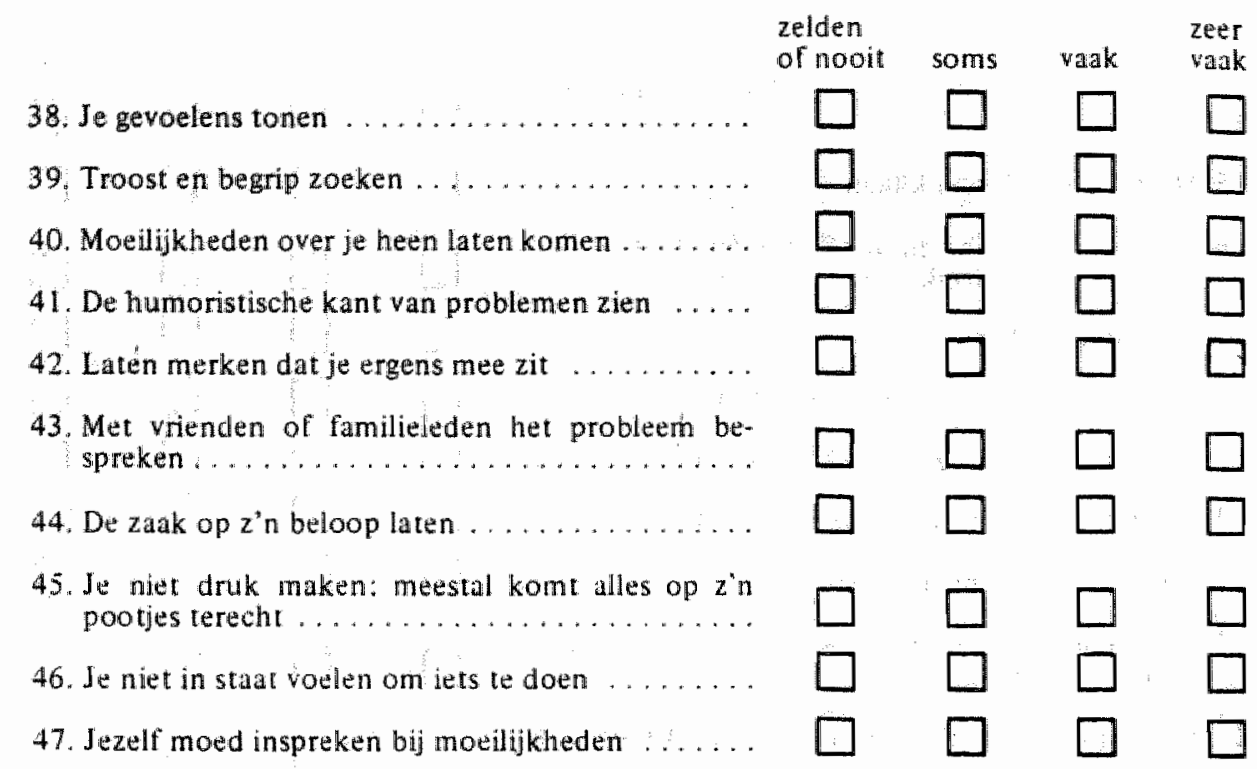




\section{BIJLAGE E}

DEFENSIE-MECHANISMEN LIJST (DMI-verkorte versie)

Auteurs: Schreurs, van de Willige, Passchier.

\section{Toelichting}

Op de volgende bladzijden staan een aantal korte verhaaltjes. Onder ieder vexhaaltje staan 4 vragen ( $\mathrm{t} / \mathrm{m} I V)$, dle elk 5 antwoordmogelijkheden hebben. Wij vragen $u$ om $u$ in te beelden dat de gebeurtenis die in het verhaaltje beschreven wordt, $u$ in werkelijk overkomt, ook al heeft $u$ lets dergelijjks nog noolt meegemaakt.

Het is de bedoeling dat $u$ telkens een antwoord kiest dat naar uw mening het beste weergeeft hoe 1 zou handelen. Voor dat antwoord zet $u$ een plusteken in de kolom $(+)$. Daarna moet u van dezelfde vraag ook én antwoord uitklezen waarvan $u$ vindt dat het het minst weergeeft hoe u zou reageren. Voor dat antwoord zet $\mathrm{u}$ een minteken $(-)$. Laten we bijvoorbeeld aannemen dat $u$ van de 5 mogelijke antwoorden op een vraag antwoord nr. 2 het meest vindt weergeven hoe u zou reageren en antwoord nr 5. het minst. In dat geval ziet de kolom voor de vragen er als volgt uit:

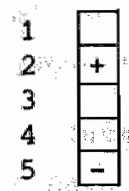

Bij elke vraag vult u dus telkens 2 hokjes in, én met een + en eén met een -. De overige hokjes blijven leeg. Leest u eerst alle 5 antwoordmogelijkheden voor u uw keuze maakt. Er zijn geen goede of foute antwoorden. U moet bedenken dat wij u niet vragen welk antwoord u het meeste bevalt en welk het minst. Het gaat on de antwoorden die het meest en het minste weergeven van de wijze warop in die situaties zou handelen en zich zou voelen. 
U staat op de rand van het trottoir op de bus te wachten. Ondat het gisternacht geregend heeft zijn de straten nat en modderig. Plotseling rijdt er een auto in razende vaart doox een plas vlak vór u en spat uw kleren onder de modder.

\section{Hoe ZOU U IN WERKELIJKHEID reageren?}

$1 . \square$ Ik zou het kentekennumer van de auto noteren om die onverschilige automobl1ist op te sporen.

$2 \square$ Ik zou me glimlachend weer schoon vegen.

$3 \square$ Ik zou de automobilist enkele scheldwoorden naroepen.

$4 \square$ Ik zou mijzelf uitschelden omdat ik nlet op zijn minst een regenjas aanhad.

5 Ik zou me er met een schouderophalen van af maken; per slot van rekening zijn dat soort dingen onvermijdelijk.

II. Wat zou u in eerste instantie (impulsief) willen doen?

1 De automobilist met $z$ " gezicht in de modder duwen.

2 De automobilist bif de politie aangeven.

$3 . \quad \square$ Mezelf een schop geven omdat ik te dicht bij de weg stond.

$4 \square$ De automobilist laten weten dat het me eigenlijk niet kan schelen.

$5 \square$ De automobilist laten weten dat voetgangers ook rechten hebben.

III. Welke GEDACHTE zou ex bij u kunnen opkomen?

$1 \square$ Waarom raak $\mathbb{1 k}$ altijd in dit soort zaken betrokken?

2 Die automoblist kan wat mij betreft dood vallen!

3 Ik weet zeker dat die automobilist eigenlijk een goeie vent is.

4. प Op regenachtige dagen kun je zolets nu eenmaal verwachten.

$5 \square$ Ik yxagg me af of ale kerel me net opzet natspatte.

IV. Hoe zou u zich op dat moment VOELEN?

$1 \quad \square$ Tevreden; per slot van rekening had het veel erger kumnen $z i j n$.

2 Teneergesiagen, vanwegle mijn pech.

3 Met berusting, omat je de dingen moet nemen zoals ze zijn.

4 Vol wrakk, omdat die automobilist zo onnadenkend was en zo weinig rekening met me hield.

Woedend, omdat hij mij smerig gemaakt heeft. 
u komt, terwlj1 a in de namiddag door de stad rljat blj eén van de drukste kruispunten. ofschoon het verkeers $11 \mathrm{cht}$ voor $\mathrm{u}$ op groen springt, zlet $\mathrm{u}$ dat er voetgangers $z i j n$ die $z l c h$ niets aantrekken van het rode voetgangerslicht en $u$ de weg versperren. o probeert de bocht met de nodige voorzichtigheid te nemen voor het licht weer op rood gesprongen is. Terwljl u de bocht neemt sommeert een verkeersagent $u$ om naar de kant van de weg te konen on beschuldigt $u$ ervan dat $u$ de voetgangers geen voorrang hebt verleend. $U:$ verklaart dat $u$ het enige hebt gedaan dat u kon doen, mar de agent geeft u niettemin een bon.

\section{Hore zou u IN WERKKLIJKHEID reageren?}

$1 \square$ Ik zou het mezelf kwalijk nemen dat ik zo zorgeloos ben geweest.

$2 \square$ Ik zou naar de rechtbank gaan en een aanklacht tegen de agent indienen.

$3 \square$ Ik zou de agent vragen of hil lets tegen automobilisten heeft.

$4 \quad$ Ik zou proberen met de agent mee te werken; per blot van rekening is het een goede vent.

$5 \quad \square$ Ik zou de bon accepteren omdat de agent niet meer dan zijn plicht deed.

II. Wat zou u in eerste instantie (impulsief) willen doen?

$1 \square$ De agent vertelien dat hij zijn funktle niet kan gebrulken on maar met me te doen wat hil wil.

$2 \square$ Mezelf verwiften dat ik niet op het volgende groene licht gewacht heb.

$3 \square$ De agent bedanken omdat hij me voor een moglelijke aanrijalng gespaard heeft.

$4 \square$ Uit principe voor mijn rechten opkomen.

$5 \square$ De deur voor zijn gezicht dichtslaan en wegrijden.

III. Welke GEDACHTE zou er bij th op kunnen komen?

$1 \square$ Hij handelt julst, ik zou hem eigenlijk moeten bedanken, omdat hij me een belangrijke les leert.

$2 \square$ Iedereen moet aljn werk naar elgen goeddunken uitvoeren.

$3 \square$ Laat ale kerel zich blj zijn wijkrondjes houden.

$4 \square$ Hoe kon ik zo stom zijn!

5 . $\square$ wed dat hij een klck krijgt van het bekeuren van mensen.

IV. Hoe zou u zich op dat moment VOELEN?

$1 \square$ Kokend van woede, ondat hif moel11 jkheden maakt.

$2 \square$ vol hatgevoelens, ondat hij mij moet hebben.

$3 \square$ Beschaama, omdat ik onvoorzlchtig was.

$4 \square$ onverschillig; per slot van rekenlng gebeurt dit soort alngen altija.

$5 \quad$ Opgelucht, omdat voorkomen is dat ik in grotere moelidjkheden terecht kwam. 
U woont bif een oom en tante in huis. Ze hebben voor u gezorgd sinds uw ouders bij een auto-ingeluk omkwamen, taen $u$ nog jong was. Op de avond dat $u$ en lat afspraakje heeft met degene waarmee u "gaat" "woedt er een hevige storm bulten. Uw dom tante dringen ex op aan dat u opbelt en het afspraakje afzegt vanwege het weer en het late uur. U staat op het punt on hun wensen te negeren en de deur uit te gaan, als uw oom op een bevelende toon zegt: "Je tante en ik heblben gezegd dat je niet kan gaan en daarmee uit".

\section{Hoe zou u IN WERKELIJKHEID reageren?}

$1 \square$ Ik zou doen wat mijn oom zei, omdat hij altijd het beste met me voor heeft gehad.

$2 \square$ Ik zou hen zeggen: "Ik heb altija al geweten dat u niet wilde dat ik volwassen merd".

$3 \quad$ Ik zou mijn afspraakje afzeggen omdat je de vrede moet bewaren in het gezin.

$4 \square$ Ik zou hem zeggen dat ze er nlets mee te maken hadden, en in ieder geval uitgaan.

5 Ik zou het er mee eens zijn on thuis te blijven en mij verontschuldigen dat $\mathbf{i k}$ hen van streek gemaakt heb.

II. Wat zou u in eerste instantle (impulsief) willen doen?

1 Met mijn hoofd tegen de muur bonzen.

2 Hen zeggen dat ze moeten ophouden mijn leven te ruineren.

$3 \square$ Hen bédanken omdat ze zo bezorgd zijn voor mijn welzijn.

$4 \square$ Vextrekken en de deur achtex me dichtslaan.

$5 \square$ Mijn afspraak nakomen; weer of geen weer.

III. Welke GEDACHTE zou er bij u op kunnen komen?

$1 \square$ Warom houden ze nlet hun mond en laten ze me met rust?

$2 \square$ ze hebben zich noolt echt om mif bekommerd.

$3 \square$ ze zljn zo goed voor me, ik zou hun advies zonder meer moeten opvolgen.

$4 \square$ Het is nu eenmaal geven en nemen.

$5 \square$ Het is allemaal mijn efgen schuld omdat ik de afspraak op zo'n laat tifdstip gezet heb.

IV. Hoe zou u zich op dat moment vOELEN?

$1 \square$ Geêrgerd, omat ze doen alsof $i k$ een kind ben.

$2 \square$ Ellendig, omdat ik weinig meer kan doen.

3. $\square$ Dankbaar voor hun zorg.

$4 \square$ Met berusting, per slot van rekening kun je niet altija je zin krijgen.

$5 \square$ wordend, omdat zij zich met mijn zaken bemoeien. 
Op zekere midag kont uw vilend onverwachts langs terw1 j1 u met uw beste vriendin aan het studeren bent voor het examen. of schoon $\mathrm{u}$ al meer dan een jaar vaste verkering hebt met hem, hebt 4 elkaar de laatste tlja nlet veel kunnen zlen; daarom vindt $u$ het fijn dat hij gekomen is o stelt hem voor aan uw vrlendin en met $z$ ' $n$ drleen praat $u$ gezellig een uurtje. Een parr dagen later belt $u$ hem op om samen het elnde van de examenweek te gaan vieren. Maar hij zegt dat hij erg verkouden is en het beter vindt om thuis te blijven. Na het eten verveelt u zlch wat en beslult om naar de flim te gaan. Als u de bioskoop uitkont, loopt plotseling uw vriend en uw vriendin tegen het lijf, arm in arm.

\section{Hoe zou U IN WERKEIIJKHEID reageren?}

$1 \square$ Ik zou hem zeggen, dat hif me had kunnen vertellen dat het uit was, in plaats van mif te bedriegen.

$2 \square$ Ik zou hen beleefd groeten zoals het hoort.

$3 \square$ Ik zou hen zeggen dat ik niets meer met hen te maken wlide hebben.

$4 \square$ Ik zou hen zeggen dat ik het leuk vind dat ze vrienden geworden $z i j n$.

$5 \square$ Ik zou me verschuilen on hen te vermifden.

II. Wat zou $u$ in eerste instantie (impulsief) willen doen?

1. $\square$ zo snel mogelijk naar huls gaan.

$2 \square$ Hem in zijn gezlcht slaan.

$3 \quad$ Hen laten weten dat het me niet kam schelen aat ze samen zijn.

$4 \square$ Haar vragen of ze alleen een man kan krljgen door hem van een ander af te pikken.

$5 \square$ Zeggen dat het begrijpelijk is dat ze zlch tot elkaar aangetrokken voelen.

\section{Welke GEDACHTE zou er blj y op kunnen komen?}

1 Natuurlijk vinat hij haar aardig, ze is veel leuker dan $1 \mathrm{k}$ ben.

2 . $\square$ Egen belang kan maken dat je beste vxienden ontrouw worden.

3 Het zijn een stel bedrlegers

$4 \quad \square$ Ik hoop dat ze hun verdiende loon krijgen.

$5 \square$ ze vormen eigenlijk een leuk stel.

IV. Hoe zou u zLch op dat moment voELEN?

$1 \square$ Blij, omdat ze zo goed met elkaar op kunnen schleten.

2 Van streek omdat ik niet zo vol vertrouwen had moeten $\mathrm{z}$ in.

$3 \square$ Berustend, omdat je het leven moet nemen zoals het valt.

4 . $\square$ Met afkeer, vanwege hun oneerlijkheid.

5 Woedend, omdat ze zolets deden. 
u wedjvert wet een wroegere schoolvriend(in) on een pas open gevallen leddende positie in het bedrljf waar u werkt te verkrijgen. ofschoon uw belder kansen ongeveer even hoog zijn, heeft uw vriend(in) meer de gelegenheld gehad om $21 \mathrm{jn} / \mathrm{haar}$ vindingrijkheld te tonen. Maar ook $u$ heeft onlangs enkele ultstekende resultaten bereikt. Toch besludt de direktie om uw vriend ( In) te bevorderen in plaats van $u$.

\section{Hoe ZOU U. IN WERKELIJKHEID reageren?}

1 Ik zolu er achter proberen te komen welk alrektielia tegen mij gestend heeft.

2

Ik zou mijn plicht blijven doen, zoals een verantwoordelijk persoor betaamt.

3

Ik zou de uitslag als bewijs zien dat ik niet geschikt ben voor di positile.

4

Ik zou sterk tegen de beslissing van de direktie protesteren.

5 Ik zow mijn vriend met zijn promotie feliciteren.

Ir. Wat zou u in eerste instantie (impulsief) willen doen?

$1 \square$ De direktie vragen on terug te komen op de beslissing omdat een ver gissing rampzalig zou zijn woor het bedrijf.

2

Mezelf verwijten dat $i k$ een baan wilde hebben war ik nilet goed genoeg voor was.

3

De direktie laten zien hoe partijaig $z i j$ in hun keuze zijn geweest.

4 Mijn vriend helpen om de nieuwe baan tot een succes te maken.

$\square$ De nek breken van elk lid van de alrektie.

\section{Welke GEDACHIE zou er bif u op kunnen komen?}

$1 \square$ Ik denk dat ik gewoon niet geschikt voor die baan ben.

2 Ik zou waarschijnljjk minder plezlex hebben in een leldende positie dan $1 \mathrm{n}$ de ban ale ik nu heb.

3 Er zlt beslist een raar luchtje aan de beslissing van de direktie.

4

5 Je moet zulke tegenslagen kunnen aanvaarden in je leven. De hele direktle kan barstent

\section{Hoe zou u zich op dat moment VOELEN?}

$1 \square$ Prettig, ondat $1 \mathrm{k}$ nog steeds mijn oude verterouwde baan heb.

2. Z Van streek, omdat mijn onbekwaamheid openbaar gemaakt werd.

3 Woedend op de drekteuren vanwege de behandeling ale ze me gaven.

4 Met berusting, want zo gaat het nu eenmal in het leven.

5 Boos, ondat ik het slachtoffer geworden ben van een onrechtvaardige besllssing. 


\section{SUMMARY}

Essential hypertension is of unknown etiology, assumed to be of a multifactorial origin: family history, constitutional, developmental, physiological, psychological, environmental and dietary factors are all presumed to contribute to blood pressure response and regulation.

A distinction should be made between transient increases in blood pressure levels and, sustained hypertension. Although this has not been proven a fact in humans, it is reasonable to conclude that repeated, pronounced and longlasting increases in blood pressure may increase the risk of sustained hypertension.

The psychosocial characteristics of individual patients in the clinical setting can have great relevance to both treatment indications and the understanding of pathogenesis. They do not, however, allow for general conclusions regarding the etiology of essential hypertension. This should be investigated in prospective epidemiological research.

The one most often researched psychosocial variable affecting high blood pressure is that of social class. A wide variety of measurements have been made on socioeconomic status (SES), income and education. As a result, a formerly positive association between the two has now been reversed: there is no proof that hypertension is more prevalent in lower classes than in higher ones.

Life events and daily hassles could well play an important role in the etiology of essential hypertension, Research has shown that extreme situations such as military combat, natural disaster, bereavement and so forth can lead to blood pressure elevation for a sustained period of time. Less serious circumstances, too, can contribute to transient blood pressure elevations. The less serious circumstances researched ranged from long exposure to noise to complex social phenomena such as unemployment and heavy work loads.

While there is some evidence linking stressful life events with the diagnosis of hypertension, the results are equivocal. The exact moment of the onset of hypertension is often unknown and is, therefore, especially problematic. The Holme-Rahe technique of measuring life change units utilizes standard weights for each event and is suited for large scale studies. The main difficulty with it, is that a particular event may be perceived differently by different subjects. However a number of modifications to this technique have been proposed which take individual perception of events into account (Rahe 1974).

Dohrenwend and Dohrenwend (1974) have summarized a number of 
dimensions relevant to the study of life events. These are: intensity, duration, frequency, (un)predictability and (un)controllability as perceived by the individual. There has been a growing conviction in recent years that belief about one's personal control are implicated in stress and coping. How these beliefs influence stress and coping is not clear however. Believing that an event is controllable does not always lead to a reduction in stress and believing that an event is uncontrollable does not always lead to an increase in stress.

The current emphasis in "stress and illness" research is on moderating variables. The low correlations between life events and physical symptomatology has prompted attempts to specify the variables responsible for buffering the illness-provoking effects of stress. The list of variables includes constitutional strengths, psychological characteristics, coping behaviour and social support.

It is generally argued that people will fare better when faced with stressful life events if they receive social support. However, the generalization that social support will protect one against psychological and physical health problems requires further research. Social support has been hampered by a lack of clarity in defining and conceptualizing its effects on health. The literature on social support in relation to the etiology of essential hypertension is scarce and generally limited to the aspects of social disconnection (e.g. loss or lack of social ties due to death, separation, or singleness Schaefer et al 1981). The mechanism by which social support mediates its buffering effects is not known. It may take place on several levels. It may reduce the objective environmental stress factors, affect only the perceived stress factors and reactions, or increase the coping resources of an individual.

It has been indicated that hypertension is more prevalent in some occupational groups, such as air traffic controllers (Cobb, 1973), telephone operators (Miasnikov, 1961), bus and tramdrivers (Holme, 1977) and prison personnel (Kalimo, 1980). These studies suggest that the blood pressure of those who must work under permanent mental stress may be elevated. It is possible that jobs which require a permanent mental load or mental overload influence blood pressure. Hypertensives are often described as people who feel threatened most of the time; they are constantly on guard for unexpected and unpleasant events (Graham, 1972). Weiner, Singer and Reiser (1962) have reported that hypertensives tend to defend themselves against potentially emotional clinical interviews by insulating themselves: they become detached or uninvolved. From research by Zimmerman (1978) and Minsky (1978), it appeared that hypertensives use more 'passive' coping strategies in varying situations. Normotensives use 'active' strategies. Handkins and Munz (1978) have shown that people with essential hypertension systematically perceive certain situations differently from normotensives. Situations considered by normotensives as stress-inducing (at issue were problematic interpersonal 
relations), were not observed and assessed as such by hypertensives. In other words, the hypertensives denied the threatening nature of these situations. This was also the case in an experiment done by Sapira (1971). There is thus evidence that hypertensives may misperceive or deny the aversive qualities inherent in threatening and "potentially hostile" interpersonal encounters: "a defensive style that may promote submissive, deferential and inhibited behaviour in hypertensives by permitting a more benign appraisal of situation typically calling for assertive responding' (Manuck 1984).

Miller (1980) and Miller and Dworkin (1977) have speculated that essential hypertension may develop, when elevations in blood pressure serve as 'coping responses'. Miller has suggested that individuals who are unable to manage stress psychologically may learn to cope physiologically; that is by elevating blood pressure so as to produce the sedative-like effects that accompany baroreceptor stimulation. These elevations in blood pressure then continue to occur in stressful situations because they are reinforced by immediate reductions in stress emotions. In the long run, however, they could be expected to contribute to the hemodynamic disregulation (Schwartz, 1977) that occurs in the early stages of essential hypertension.

In a follow-up study on air traffic controllers, Jenkins (1984) showed that persons who remained normotensive reported the greatest amount of life change stress. Prevalence cases of hypertension reported the lowest life change distress and future cases recorded intermediate levels. Future hypertensives clearly showed the highest average level of work satisfaction and satisfaction with co-workers. Normotensives had the lowest averages on both these scales. These findings are thus in conflict with the usual stress theory. They are consistent, however, with the hypothesis that hypertensives perceive their world in a way quite different from normotensives. The hypertensives deny the negative aspects of circumstances around them. If psychosocial variables do not provide much help in understanding differences between hypertensives and normotensives, greater insights may be obtained by considering the ways in which people cope with the problems which confront them.

The role of personality in the etiology of high blood pressure has been a subject for discussion for many years. The question whether a 'hypertensive personality" exists - characterized mainly by the suppression of hostility (Alexander, 1939) - has been an important theme. Even when the first psychoanalytical and highly subjective descriptions were replaced by predefined instruments for measurements, the differences in nomenclature precluded comparison. In addition to the research into evidence for this 'repressedhostility hypothesis", the relation to various psychological factors and traits has been explored, e.g. anxiety, agitation, obsessive and compulsive behaviour, neuroticism etc. (see Harrell, 1980). More recently the relation between hypertension and global orientations (Ostfeld and Eaker, 1985) and 
copingstyles have been researched: items such as internal versus external locus of control (Wennerholm and Zarle, 1976; Naditch, 1974), assertiveness (Manuck, 1984) and type-A behaviour. In general, essential hypertension is associated with the development of cardiovascular diseases and type-A behaviour - in some but not all studies - has been linked to coronary heart disease. Although type-A behaviour is not a necessary characteristic of people with hypertension, it has been demonstrated that when type-A men are exposed to stress they experience a significantly larger rise in systolic blood pressure than type-B men (Dembroski et al 1977; Manuck 1978). The differences in reaction of the systolic blood pressure usually took place when the subjects researched were confronted with challenging situations. Obrist $(1976,1979)$ concluded that adrenergic influences are most often evoked and sustained, when subjects actively attempt to cope with a stressor.

There is no single projective study that clearly links high blood pressure with a specific personality pattern. Problems arise because projective tests are difficult to administer and score, and require a skilled interpreter. Although projective tests may offer a rich source of information to the clinician, their lack of objectivity in scoring, adequate standardization, and their questionnable validity cause problems for the experimenter.

Yet neither the Rozenzweig P F, the Rorschach, and the Draw-a-person-test has failed to yield evidence that a 'hypertensive personality' exists.

Some investigators have developed rating scales by which they judge their subjects, personality characteristics. In many cases, not much is known about the validity, the reliability and the norms. However, a lot of paper and pencil inventories exist which are valid and reliable. Basically, all these paper and pencil inventories consist of a variety of statements about actions and feelings, to which an individual must respond by indicating whether these are characteristic of him or not. Because they are based on self-assessment, the tests are subject to such factors as an individual's memory, intelligence, motivitional state, ete. All these can be sources of error. Most of the studies into personality characteristics have not yielded specific characteristics of people with essential hypertension. Many of the results appear to be incompatible with each other. This is partly due to a number of methodological inadequacy of the instruments and non-representative samples. Nevertheless, a reasonable consistent overall picture of the personality of persons with essential hypertension does emerge. According to Julius and Cottier (1983) this is characterized by submissiveness to other people, by an attempt to control behaviour so as to be socially acceptable and by difficulties in expressing hostile feelings.

Psychological characteristics of hypertensives may either be a cause or a consequence of their disorder. Patients who suffer from sustained hypertension generally have peripheral arteriolar hypertrophy which is the 
result of a long process. Personality or environmental factors which were involved at the beginning of this process may be absent when this person became a patient.

This dissertation concerns itself with the question of whether or not hypertensives differ from normotensives in personality traits, and if different social circumstances are involved. These questions are relevant to the need for the development of psychotherapeutic programs for borderline hypertensives. A better understanding of the role of personality and social factors in the etiology and maintenance of essential hypertension can be very helpful in treatment-indication.

As previously discussed in detail in chapter 2, a lot of research has been done in order to discover the hypertensive-personality. The results are often contradictory. It is impossible to derive clear conclusions due to methodological problems, the use of varying criteria for hypertension and the use of poorly validated personality-trait questionnaires.

In our first study, described in chapter 5 , we selected 46 hypertensives and 49 normotensives. During the two measurement periods in the last half year the hypertensives had at least a mean systolic bloodpressure of over 160 and/or a mean diastolic bloodpressure of over $100 \mathrm{~mm} \mathrm{Hg}$, or they received antihypertensive medication. The following personalities were measured: type-A behaviour pattern (JAS), internal-external locus of control (Rotter-Scale), neuroticism (EPI), extraversion (EPI), assertiveness (SIG), anxiety (TaylorScale), anger (State Anger Scale) and defense mechanisms (DMI). Hypertensives were older and had a higher quetelet-index than normotensives. The personality traits could scarcely differentiate the hypertensives and normotensives. Only one major difference manifested itself namely that hypertensives had a higher anxiety-score than normotensives. Another small significance was detected for a subsample of hypertensives whose blood pressure was too high, for the last two years. They reported more contributing life events and scored higher on the defense mechamism termed "turning against object'; i.e. they were more aggressive.

In the second study, 1200 respondents were involved. One hundred twentyseven men ware diagnosed as hypertensive. The following criteria were used: 1. systolic measurements of over $160 \mathrm{~mm} \mathrm{Hg}$ and/or diastolic of over $100 \mathrm{~mm}$ $\mathrm{Hg}$ or, 2. classified by their physician as hypertensive patients who received anti-hypertensive medication. We selected 770 men who had normall blood pressure and had never been diagnosed as hypertensive. We measured the following personality traits: State-anxiety and state-anger, internal-external locus of control, assertiveness, type A behaviour-pattern. Coping strategies and defense mechanisms too, were measured. Besides psychological factors, we also assessed social factors such as living circumstances, work-related factors and the social support-system. 
There were no differences in the psychosocial factors between the several subgroups of hypertensives who were selected on the basis of the variables anti-hypertensive medication and the time of the onset of hypertension. It was thus not necessary to treat these variables as confounders. Hypertensives were significantly older and had a higher quetelet-index. There was no difference with the normotensive group with regard to social class.

We were unable to differentiate hypertensives from normotensives on the basis of personality and social factors. Neither the univariate analysis of the relation between psychosocial factors and hypertension, nor the multivariate analysis revealed a significant result.

Through clusteranalysis over the hypertensive respondents we were able to create two subgroups. One group of hypertensives could be described (in relation to normotensives) as being highly anxious, with a high anger-state, external locus of control, aggressive and a high level of copingstrategy avoidance. The other subgroup consisted of hypertensives who were less anxious, had a lower state-anger and a more internal locus of control. They were less aggressive. In this respect, we could confirm our initial hypotheses on the existence of two groups. This distinction based on the same variables, however, could also be made in the group of normotensives. We concluded that there is evidence in the literature, confirmed by our studies, that there are several subtypes of hypertensives. It is also possible that there are different pathogenesis and that different psychosocial factors play a role in the etiology and maintenance of essential hypertension. In this respect it is no longer worthwile to continue a cross-sectional analysis of personality traits without looking at these different subtypes. We therefore propose research in which the specific copingstrategies are studied intra-individually and longitudinally: 'What are the cognitive and behavioural efforts which normotensives who stay normotensive and future hypertensives use to master, reduce or tolerate stressful sítuations.' 



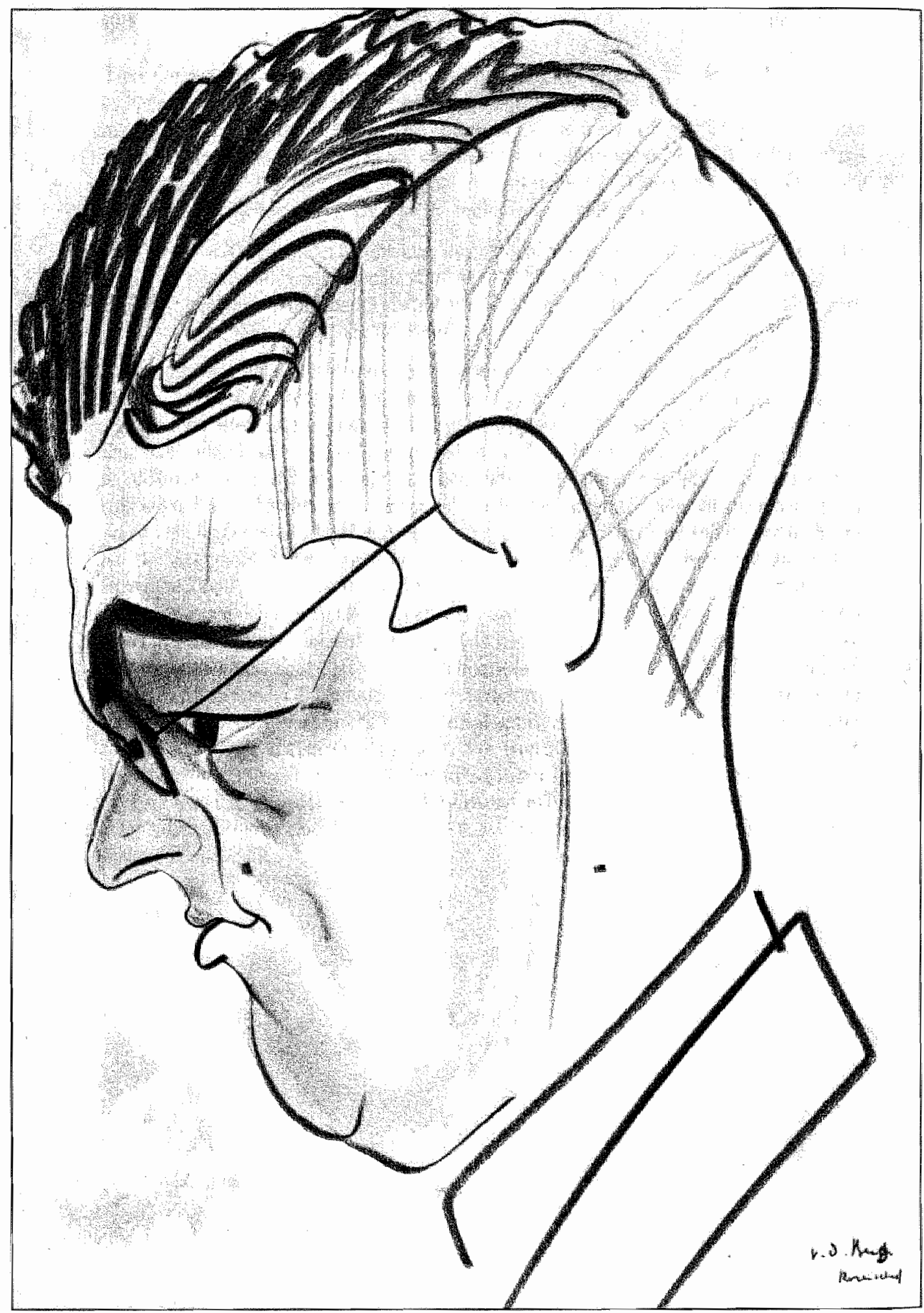




\section{CURRICULUM VITAE}

Paul Schreurs werd op 18 juli 1946 te Venlo geboren.

Hij is getrouwd met Annemie Turien en heeft twee zonen, Onno en Mark. $\mathrm{Na}$ het behalen van het HBS-B diploma aan het St. Thomascollege te Venlo in 1965, ging hij psychologie studeren in Utrecht. In meil 1972 behaalde hij het doctoraalexamen met als hoofdvak klinische psychologie, nevenrichting functiepsychologie en als bijvakken psychopathologie en psychofysiologie.

Tijdens zijn doctoraalstudie was hij student-assistent bij de vakgroep psychofysiologie en was hij verbonden als docent psychologie aan de opleidingsafdeling van het Antonius Ziekenhuis te Utrecht.

Van 1972 tot 1975 volgde hij de opleiding tot gedragstherapeut en nam hij deel aan het ZWO-project agorafobie. Momenteel is hij opleider en supervisor van de Vereniging voor Gedragstherapie.

In 1974 werd hij door de Rijksuniversiteit Utrecht aangesteld als onderzoeker binnen het project 'therapeutische toepassings-mogelijkheden van biofeedback-procedures bij essentiële hypertensie'.

Sinds 1977 is hij verbonden aan de vakgroep klinische psychologie van de RU te Utrecht en werd er in 1986 universitair hoofddocent.

Hij vervult een bestuursfunctie in de sectie Behavioral Medicine van de Vereniging voor Gedragstherapie en is secretaris van het bestuur en van de wetenschappelijke adviesraad van de Nederlandse Stress Stichting.

Onlar. $s$ is hij toegetreden tot de redactie van het tijdschrift Gedrag en Gezonuheid. 